\title{
Annotated Directory of Threatened and Endangered Wildlife on Selected U.S. Army Installations East of the Mississippi River
}

by

David J. Tazik

Renee A. Sherman

Jeffrey A. Courson

The Army is required to protect state and federally listed threatened and endangered species on lands under its control. This can have a direct effect on the use and management of those lands. The Army needs to determine the extent of potential endangered species problems on Army lands as a basis for developing long term management strategies to protect listed species while minimizing negative effects on the Army's training and testing missions.

This report summarizes available information on the known or potential occurrence of federal and state listed threatened and endangered species on major Army installations east of the Mississippi River. This information is intended to alert installation land managers to the potential for endangered species on lands under their management, and to provide Army planners and administrators with a ready source of comparative information on the endangered species management burden among installations.

Approved for public release; distribution is unlimited. 
The contents of this report are not to be used for advertising, publication, or promotional purposes. Citation of trade names does not constitute an official indorsement or approval of the use of such commercial products. The findings of this report are not to be construed as an official Department of the Army position, unless so designated by other authorized documents.

DESTROY THIS REPORT WHEN IT IS NO LONGER NEEDED

DO NOT RETURN IT TO THE ORIGINATOR 
Public reporting burden for this collection of information is estimated to average 1 hour per response, including the time for reviewing instructions, searching existing data sources, gathering and maintaining the data needed, and corrpleting and reviewing the collection of information. Send comments regarding this burden estimate or any other aspect of this collection of information, including suggestions for reducing this burden, to Washington Headquarters Services, Directorate for information Operations and Reports, 1215 Jefferson Davis Highway, Suite 1204, Arlington, VA 22202-4302, and to the Otfice of Management and Budget, Paperwork Reduction Project (0704-0188), Washington, DC 20503.

\begin{tabular}{|l|l|l|}
\hline 1. AGENCY USE ONLY (Leave Blank) & 2. REPORT DATE & 3. REPORT TYPE AND DATES COVERED
\end{tabular} May 1991

Final

4. TITLE AND SUBTITLE

Annotated Direcorty of Threatened and Endangered Wildlife on Selected U.S. Army Installations East of the Mississippi River

6. AUTHOR(S)

David U. Tazik, Renee A. Sherman, and Jeffrey A. Courson

7. PERFORMING ORGANIZATION NAME(S) AND ADDRESS(ES)

U.S. Army Construction Engineering Research Laboratory (USACERL)

P. O. Box 9005

Champaign, IL 61826-9005

9. SPONSORING/MONITORING AGENCY NAME(S) AND ADDRESS(ES)

U.S. Army Engineering Housing and Support Center

ATTN: CEHSC-FN

Fort Belvoir, VA 22060-5516

11. SUPPLEMENTARY NOTES

Copies are available from the National Technical Information Service, 5285 Port Royal Road,

Springfield, VA 22161

12a. DISTRIBUTION/AVAILABILITY STATEMENT

Approved for public release; distribution is unlimited.

12b. DISTRIBUTION CODE

13. ABSTRACT (Maximum 200 words)

The Army is required to protect state and federally listed threatened and endangered species on lands under its control. This can have a direct effect on the use and management of those lands. The Army needs to determine the extent of potential endangered species problems on Army lands as a basis for developing long term management strategies to protect list species while minimizing negative effects on the Army's training and testing missions.

This report summarizes available information on the known or potential occurrence of federal and state listed threatened and endangered species on major Army installations east of the Mississippi River. This information is intended to alert installation land managers to the potential for endangered species on lands under their management, and to provide Army planners and administrators with a ready source of comparative information on the endangered species management burden among installations.

\begin{tabular}{|c|c|c|c|}
\hline \multirow{2}{*}{$\begin{array}{l}\text { 14. SUBJECT TERMS } \\
\text { Endangered species } \\
\text { Army facilities }\end{array}$} & \multirow{2}{*}{$\begin{array}{l}\text { Threatened species } \\
\text { Eastern U.S. }\end{array}$} & \multirow{2}{*}{$\therefore$} & $\begin{array}{l}\text { 15. NUMBER OF PAGES } \\
192\end{array}$ \\
\hline & & & 16. PRICE CODE \\
\hline $\begin{array}{l}\text { 17. SECURITY CLASSIFICATION } \\
\text { OF REPORT } \\
\text { Unclassified }\end{array}$ & $\begin{array}{l}\text { 18. SECURITY CLASSIFICATION } \\
\text { OF THIS PAGE } \\
\text { Unclassified }\end{array}$ & $\begin{array}{l}\text { 19. SECURITY CLASSIFICATION } \\
\text { OF ABSTRACT } \\
\text { Unclassified }\end{array}$ & $\begin{array}{l}\text { 20. LIMITATION OF ABSTRACT } \\
\text { SAR }\end{array}$ \\
\hline NSN $7540-01-280-5500$ & & & $\begin{array}{l}\text { Standard Form } 298 \text { (Rev. 2-89) } \\
\text { Proscribod by ANSI Std 239-18 } \\
298-102\end{array}$ \\
\hline
\end{tabular}




\section{FOREWORD}

This work was conducted for the U.S. Army Engineering Housing and Support Center (USACEHSC), U.S. Army Corps of Engineers (USACE) under Funding Authorization Document (FAD) Numbers 88080154, 89080046, and 90080586. The USAEHSC Technical Monitor was Mr. Donald Bandel, CEHSC-FN.

The work was performed by the Environmental Division (EN), U.S. Army Construction Engineering Research Laboratory (USACERL). Renee A. Sherman is employed by the Center for Aquatic Ecology, Illinois Natural History Survey, Champaign, IL. Dr. Edward W. Novak is Acting Chief, USACERL-EN. The USACERL technical editor was Gloria J. Wienke, Information Management Office.

COL Everett R. Thomas is Commander and Director of USACERL and Dr. L.R. Shaffer is Technical Director. 


\section{CONTENTS}

SF298

FOREWORD 2

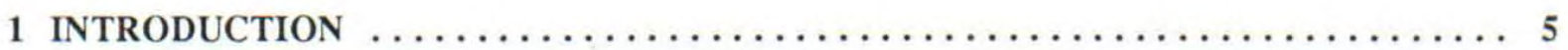

$\begin{array}{ll}\text { Background } & 5\end{array}$

Objective $\quad 6$

Approach $\quad 6$

Scope 7

Mode of Technology Transfer $\quad 7$

2 ENDANGERED SPECIES ACT $\ldots \ldots \ldots \ldots \ldots \ldots \ldots \ldots \ldots \ldots \ldots \ldots \ldots \ldots \ldots$

$\begin{array}{lr}\text { Exemptions and Exceptions } & 10\end{array}$

Endangered Species and the Army 11

Integrated Training Area Management $\quad 12$

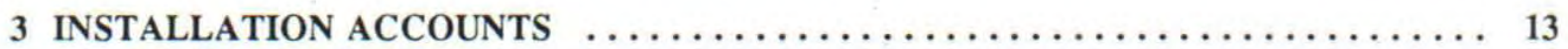

$\begin{array}{ll}\text { Aberdeen Proving Ground } & 14\end{array}$

Anniston AD $\quad 16$

Camp Atterbury $\quad 18$

$\begin{array}{ll}\text { Badger AAP } & 21\end{array}$

Fort A.P. Hill $\quad 24$

$\begin{array}{ll}\text { Fort Belvoir } & 25\end{array}$

$\begin{array}{ll}\text { Fort Benning } & 27\end{array}$

Camp Blanding $\quad 29$

Fort Bragg 31

Fort Campbell

Fort Devens

Fort Dix $\quad 42$

Fort Drum $\quad 46$

$\begin{array}{lr}\text { Camp Edwards } & 48\end{array}$

Fort Eustis $\quad 51$

Fort George Meade $\quad 53$

Fort Gordon $\quad 54$

Camp Grayling $\quad 56$

Indiana AAP $\quad 58$

Fort Indiantown Gap $\quad 61$

Fort Jackson $\quad 63$

Jefferson Proving Ground $\quad 65$

$\begin{array}{ll}\text { Joliet AAP } & 67\end{array}$

Fort Knox $\quad 72$

$\begin{array}{ll}\text { Fort Lee } & 77\end{array}$

$\begin{array}{ll}\text { Letterkenny AD } & \mathbf{7 8}\end{array}$

Lexington/Bluegrass $\quad$ ?

Fort McClellan $\quad 83$

Fort McCoy $\quad 86$ 


\section{CONTENTS (Cont'd)}

Milan AAP

Mississippi AAP

Newport AAP

Picatinny Arsenal

Fort Pickett

Radford AAP

Ravenna AAP

Redstone Arsenal

Fort Rucker

Camp Santiago

Savanna AD

Seneca AD

101

103

105

108

110

Camp Shelby

112

116

Fort Stewart

118

Fort Story

119

121

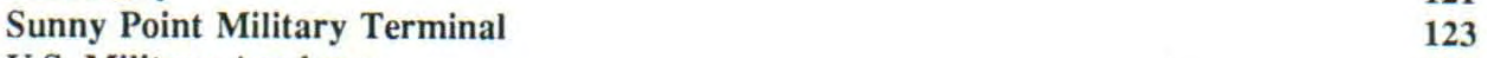

U.S. Military Academy $\quad 126$

Volunteer AAP

APPENDIX A: ENDANGERED SPECIES LISTING SORTED BY INSTALLATION AND STATUS

APPENDIX B: ENDANGERED SPECIES LISTING SORTED BY SPECIES AND STATUS

APPENDIX C: A STANDARD STATUS REPORT FORMAT FOR

THREATENED AND ENDANGERED ANIMAL SPECIES ON ARMY LANDS 


\section{ANNOTATED DIRECTORY OF THREATENED AND ENDANGERED WILDLIFE ON SELECTED U.S. ARMY INSTALLATIONS EAST OF THE MISSISSIPPI RIVER}

\section{INTRODUCTION}

\section{Background}

The Army is required to protect state and federally listed threatened and endangered species on lands under its control. ${ }^{1}$ This can have a direct effect on the use and management of those lands. Presence of threatened or endangered species can (1) limit land uses, including training activities, (2) result in direct conflicts with the military mission, (3) require added financial and personnel resources to take affirmative action on behalf of listed species, and (4) involve state and federal wildlife agencies in Ärmy land use decisionmaking. There is a need to determine the extent of potential endangered species problems on Army lands as a basis for developing long term management strategies to protect listed species while minimizing negative effects on the Army's training and testing missions.

The number of species protected by endangered species laws is large and is rapidly increasing. As of July 1990 there were 588 species listed as federally threatened or endangered -61 mammals, 87 birds, 32 reptiles, 11 amphibians, 84 fishes, 78 invertebrates, and 235 plants. $^{2}$ The number has increased steadily at an average of 26.5 species per year since 1973, the year the Endangered Species Act was enacted. At this rate, an additional 252 species will be listed by the year 2000, for a total of 840 species. Trends at the state level are likely to be similar.

A continuing increase in the number of species listed is expected for at least four reasons. First, a reduction in wildlife numbers due to habitat destruction and other human disturbances is likely to continue. Second, there is increasing awareness of and scientific information on the traditionally less visible species whose small populations are most susceptible to extinction. Third, approximately 3,900 species of plants and animals are official candidates for listing. ${ }^{3}$ About 2,950 of these have gone unlisted because the biological status assessments required to determine the need for listing have not been completed. For the remaining 950 , information is available to support listing, but listing has been constrained by insufficient resources. ${ }^{4}$ Finally, in the future, few species are likely to be removed from the list of threatened and endangered species (delisted) because of recovery or extinction. Only five species have recovered since 1973 and six have been declared extinct. ${ }^{5}$

The potential for conflicts between endangered species and the Army mission is high. Over 12 million acres of Army managed lands are located in a diversity of ecological regions and habitat types

\footnotetext{
${ }^{1} 16$ U.S. Code (U.S.C.) 1536(a)(1); Army Regulation (AR) 420-74, Paragraph 6-2 Natural Resource - Land, Forest, and Wildlife Management (Headquarters, Department of the Army [HQDA], 25 February 1986); Federal Register (FR) 54:7539-7543, 265.7(B)(3)(b) [22 Feb 1989].

${ }^{2}$ Endangered Species Technical Bulletin, Vol 15, No. 2 (U.S. Department of the Interior, 1989) p 8.

${ }^{3}$ Endangered Species: Management Improvements Could Enhance Recovery:Program, GAO/RCED-89-5 (U.S. General Accounting Office [GAO], 1989), pp 1-100; FR 54:554-579 [6 Jan 1989].

4 "Legislative History: Endangered Species Act Amendments of 1988--African Elephant Conservation (P.L.100-478)", U.S. Code: Congressional and Administrative News, Vol 8A (West Publishing Co., 1988), pp 2700-2750.

s Endangered Species: Management Improvements Could Enhance Recovery Program.
} 
throughout the United States. Furthermore, many unique habitats exist on Army lands because private development has been restricted, and such unique areas often are left relatively undisturbed by the military despite extensive training activities. Previous research documented the presence or likely presence of 27 federally listed species and 56 exclusively state listed species on 20 major installations west of the Mississippi River. ${ }^{6}$ The diversity of ecological zones and habitats in the east will likely produce at least as many, if not more species on eastern installations.

Nonmilitary land uses on Army training and testing reservations - forestry, grazing, crop production, and hunting - may also conflict with threatened and endangered species. Recent controversy over the red-cockaded woodpecker (Picoides borealis), a permanent resident on several installations in the southeastern United States, is a case in point. This species has come into conflict with both military training and forestry practices on a number of installations. While these activities are valuable uses of Army lands, when properly managed, they are not immune to restrictions imposed by the presence of threatened and endangered species.

The Army can begin to deal effectively with the problems imposed by threatened and endangered species if steps are taken to determine the nature and extent of the problem. These steps should be followed up with selected field surveys and the development of a proactive planning process. An annotated directory of threatened and endangered wildlife on Army lands is a first step in this direction.

\section{Objective}

The objective of this research is to summarize available information on the known or potential occurrence of federal and state listed threatened and endangered species on major Army installations east of the Mississippi River. This information is intended to alert installation land managers to the potential for endangered species on lands under their management, and to provide Army planners and administrators with a ready source of comparative information on the endangered species management burden among installations.

\section{Approach}

Information was gathered on the known or probable occurrence of state and federally listed threatened and endangered wildlife species on 46 Army installations located east of the Mississippi River. Information was derived from a variety of sources including U.S. Fish and Wildlife Service (USFWS) regional offices and Ecological Services field offices, state Natural Heritage Programs, installation and Major Command (MACOM) natural resource personnel, available literature, and known experts at various colleges and universities. Summaries of species occurrences and management implications are compiled for each installation.

\footnotetext{
${ }^{6}$ Diersing, V.E., W.D. Severinghaus, and E.W. Novak, Annotated Directory of Endangered Wildlife on Selected U.S. Army Installations West of the Mississippi River, Technical Report N-85/08/ADA154623 (U.S. Army Construction Engineering Research Laboratory [USACERL], March 1985).
} 


\section{Scope}

Forty-six installations east of the Mississippi River are included in this report. Installations were selected to be representative of (1) the Major Commands, (2) a broad range in size of installations, (3) and installations with training or testing missions. Additional installation accounts will be added in the future as the information is completed.

\section{Mode of Technology Transfer}

The information developed as a result of this research should be transferred to installations and MACOMs as part of a handbook of threatened and endangered species on Army lands. The information also should be incorporated into the Army's Land Condition Trend Analysis (LCTA) Program database management system for Army-wide data summarization and dissemination. Also, a mechanism must be developed to update installation and species accounts through (1) direct input from installations and (2) expansion of and integration of data gathered in conjunction with the LCTA program. 


\section{ENDANGERED SPECIES ACT}

The Endangered Species Act of 1973 (hereafter referred to as the Act), is one of the most farreaching legislative initiatives taken by the Federal Government on behalf of wildlife. It was established to protect species of plants and animals thought to be threatened with extinction. A critical feature of the Act is the responsibility, if not burden, it places on all federal agencies to protect listed species that occupy lands under their control as well as those that might be affected by their actions. Extensive reviews can be found in other sources. ${ }^{7}$

This Act was the first piece of federal legislation to protect a group of nonsport wildlife and plants comprehensively. Previous efforts, most notably the Endangered Species Preservation Act of 1966 and Endangered Species Conservation Act of 1969, provided for protection of domestic species in danger of extinction primarily via acquisition of habitat. Neither act compelled federal agencies to pursue programs to protect endangered species, and they did not prohibit the taking of such species. This prohibition was left to the states under the concept that states had primary responsibility to regulate the taking of resident species.

The Act protects species listed as threatened or endangered by restricting taking, regulating trade, providing habitat acquisition authority, mandating consideration of impacts due to federal activities, and recognizing the international scope of the problem. Other sources provide an extensive review of the Act and amendments through $1982 .^{8}$

Endangered species, threatened species and critical habitat are the three major features of the Act. Endangered species are those in danger of extinction throughout all or a significant portion of their range. Threatened species are those likely to become endangered within the foreseeable future throughout all or a significant portion of their range. Critical habitat, formally designated by the Secretary of Interior or Commerce (hereafter referred to as the Secretary) depending upon jurisdiction, is defined as areas essential for the conservation of listed species and that may require special management consideration or protection. It can consist of a portion or the entirety of the area occupied by a listed species, as well as areas outside existing occupied areas.

Section 7, Interagency Cooperation, is the core of the Act. Under Section 7, all federal agencies are obliged to "utilize their authorities in furtherance of the purpose of this Act by carrying out programs for the conservation of endangered species and threatened species," ${ }^{\prime 9}$ and to "insure that any action authorized, funded or carried out by such agency is not likely to jeopardize the continued existence of any endangered species or threatened species or result in the destruction or adverse modification of [critical] habitat of such species."10 Under these mandates, federal agencies have (1) an affirmative duty to promote endangered species conservation and to determine the effects of their actions on listed species thought to be present, and (2) are prohibited from furthering the demise of listed species and critical habitat.

7 M.J. Bean, The Evolution of National Wildlife Law: Revised and Expanded Edition (Praeger Publishers, New York, 1983); D.J. Rohlf, The Endangered Species Act, a Guide to its Protections and Implementation (Stanford Environmental Law Society, Stanford, CA, 1989).

${ }^{8}$ M.J. Bean, 1983.

9 16 U.S.C. \$ 1536(a)(1).

${ }^{10} 16$ U.S.C. \$ 1536(a)(2). 
Section 7 also provides for consultation between an agency and the U.S. Fish and Wildlife Service (USFWS) when evidence suggests that an agency action will likely affect a listed species. ${ }^{11}$ Regulations allow for both formal and informal consultation between the affected agency and the USFWS. ${ }^{12}$ Formal consultation is required whenever an agency action may affect, positively or negatively, a listed species or critical habitat. Informal consultation is an optional procedure that includes all contacts between USFWS and the federal agency involved. "It is designed primarily to except from the formal consultation process those proposed actions which, upon further informal review, are found not likely to adversely affect a listed species or critical habitat. ${ }^{13}$ Consequently, the more demanding procedural requirements of formal consultation can be avoided when an agency action is found, through informal consultation, to be beneficial or of insignificant consequence to a listed species. It also allows an opportunity to recommend modifications to proposed actions designed to avoid potential adverse effects.

Informal consultation provides considerable flexibility in dealing with endangered species conflicts, and appears to be the preferred method of resolution. While the number of consultations, formal and informal, increased substantially between 1979 and 1987, formal consultations declined from over 35 percent to less than 5 precent of the total. ${ }^{14}$ However, although informal consultation appears to be a successful approach to accommodating both the needs of endangered species and agency mission requirements, some question remains as to whether it may be too accommodating to development interests.

Section 9, Prohibited Acts, among other things, makes it unlawful for any person subject to the jurisdiction of the United States to "take" a listed species anywhere in the United States, its territorial waters, or on the high seas. "Take" means to harass, harm, pursue, hunt, shoot, wound, kill, trap, capture, or collect, or to attempt to engage in any such conduct. ${ }^{15}$

Within this definition of take, the term "harm" has been the subject of much judicial scrutiny. The USFWS defines harm in the definition of take as "an act that actually kills or injures wildlife. Such act may include significant habitat modification or degradation where it actually kills or injures wildlife by significantly impairing essential behavioral patterns, including breeding, feeding or sheltering." ${ }^{16}$ Courts have upheld the notion that modification or degradation of a species habitat, even when it is not formally designated as "critical habitat," constitutes a harm if it threatens the species survival. Such harm is therefore a prohibited taking. ${ }^{17}$ Under this approach, a species need not be present when its habitat is altered. For example, the breeding habitat of a migratory species is protected even when it is on its wintering grounds. ${ }^{18}$

\footnotetext{
$" 16$ U.S.C. \$ $1536(a)(3)$.

1250 Code of Federal Regulations (CFR) § 402.

${ }^{13} 51$ FR 19948 (3 June 1986).

${ }^{14}$ S.L. Yaffee, "Protecting Endangered Species Through Interagency Consultation," Endangered Species Update 5:14-19 (1988).

${ }^{15} 16$ U.S.C. $\$ 1538(\mathrm{a})(1)(\mathrm{B}),(\mathrm{C})$.

${ }^{16} 46$ FR 54748,54750 (4 November 1981).

${ }^{17}$ Palila v. Hawaii Dept. of Land and Natural Resources 639 F.2d 495 (9th Cir. 1981), and Palila v. Hawaii Dept. of Land and Natural Resources 852 F.2d 1106 (9th Cir. 1988).

${ }^{18}$ M.J. Bean, 1983.
} 


\section{Exemptions and Exceptions}

Section 7 allows parties to apply for exemptions to the jeopardy clause of that section. ${ }^{19}$ An elaborate procedural process has been set up to deal with such applications. ${ }^{20}$ Applications are considered by a seven-member committee consisting of the Secretaries of Agriculture, the Army, and Interior, the Chairman of the Council of Economic Advisors, the Administrators of EPA and NOAA, and the President. The Committee may grant an exemption under the following conditions: (1) there are no reasonable or prudent alternatives to the agency action, (2) the benefits of such action clearly outweigh the benefits of altemative courses of action consistent with conserving the species or its critical habitat, and such action is in the public interest, (3) the action is of regional or national significance, and (4) neither the federal agency concerned nor the exemption applicant made any irreversible or irretrievable commitment of resources. Also, the exemption must not violate any international treaty obligations, as determined by the Secretary of State, and may be contingent upon various mitigation and enhancement measures established by the committee. An exemption must be granted if the Secretary of Defense finds that it is necessary for reasons of national security, and may be granted by the President in Presidentially declared disaster areas.

There are two situations under which a Section 9 taking may be permitted. First, agency actions that do not jeopardize the continued existence of a listed species but that do result in taking that is incidental to those actions may be permitted under Section $7 .^{21}$ However, the agency will be required to take certain "reasonable and prudent measures" to minimize any adverse effects and shall comply with other terms and conditions set forth by the Secretary.

Second, incidental taking also may be permitted under Section 10 of the Act. Before the 1982 amendments that enacted this provision, taking prohibitions could be dealt with only through criminal sanctions that were largely unenforceable. Section 10 encourages applicants to participate in endangered species conservation by establishing a formal permitting process. To obtain a permit, the applicant must submit a conservation plan that specifies, (1) likely impacts, (2) what measures will be taken to minimize and mitigate such impacts and the funding that will be available to implement them, (3) alternative actions considered and reasons for their rejection, and (4) other measures that may be required by the Secretary. ${ }^{22}$ To issue the permit, the Secretary must find that the taking is incidental to and not the purpose of the action, that adequate funding will be made available to carry out the plan, and that the taking will not appreciably reduce the likelihood of survival and recovery of the species. ${ }^{23}$

Because approximately one-third of U.S. land is controlled by the Federal Government, the Section 7 requirements of the Act are clearly significant to endangered species protection. It is also clear, despite Section 9 prohibitions against taking, that private lands are less available for endangered species protection, all the more so as these lands continue to be developed at a rapid pace. The major challenge facing federal land management agencies is and will continue to be minimizing the conflict between their primary mission(s) and the needs of endangered species. The significance of this challenge lies in the notion that the continued existence of such species may take precedence over that mission. ${ }^{24}$ Clearly,

19 16 U.S.C. \$ $\$ 1536(\mathrm{a})(1)$.

${ }^{20} 50$ CFR \$ $\$ 450-453$.

${ }^{21} 16$ U.S.C. \$ 1536(b)(4)(B).

22 16 U.S.C. \$ 1539(a)(1)(2)(A).

${ }^{23} 16$ U.S.C. \$ 1539(a)(1)(2)(B).

${ }^{24}$ Tennessee Valley Authority v. Hill 437 U.S. 153 (1978). 
it is incumbent on these agencies to incorporate endangered species considerations in their land use planning to avoid the pitfalls that are likely to arise in the absence of such considerations.

\section{Endangered Species and the Army}

The primary mission of the Army in peacetime is to maintain national defense preparedness. In carrying out this mission, the Army uses much of its land to train troops. Activities range from low impact foot training to highly destructive tracked vehicle maneuvers and artillery shelling. These and a variety of other land uses (e.g., grazing, forestry, etc.) can and do alter drastically the composition and structure of vegetation communities, which in turn can have both positive and negative effects on listed species. Presence and use of a variety of hazardous material on Army lands can also affect such species. Furthermore, many of the individual actions taken by civilian and military personnel on Army lands may result in the taking of listed species.

Army policy on the subject is found in Army Regulation (AR) 420-74. ${ }^{25}$ Amplification and clarification is also available. ${ }^{26}$ It requires compliance with the jeopardy clause of the Act, and, where applicable, the development and implementation of inventory and monitoring programs for listed species and their habitat on Army lands. Furthermore, recent Army guidance indicates that candidate species are to be considered in a proactive manner.

The Department of the Army presently is revising AR 420-74. The Department of Defense (DOD) Directive upon which it is to be based (DOD Directive 4700.4) states that, "Endangered and threatened species and their habitats shall be protected and managed according to the Endangered Species Act and implementing U.S. Fish and Wildlife Service (FWS) regulations and agreements," and that

[Fish and Wildlife] Management plans for installations with endangered species shall include:

(1) Coordinated protection and mitigation measures.

(2) Appropriate affirmative methods and procedures necessary to enhance the population of endangered species.

(3) Procedures and responsibilities for consulting with the FWS prior to funding or conducting any action likely to affect a listed species or its critical habitat. ${ }^{27}$

To comply with the affirmative and prohibitory duties mandated by the Act while also minimizing the impact of threatened and endangered species on the Army's primary mission, Army land managers must be prepared to take a proactive rather than a crises-management approach toward the endangered species problem. There are several justifications for this approach.

First, knowing the distribution, abundance and needs of threatened and endangered species on its lands will provide the Army with a realistic assessment of limitations placed by those species on use of the lands. This information in turn can serve as one basis for planning for more efficient use of existing lands and for the acquisition of new lands. Second, active pursuit of solutions to potential endangered

\footnotetext{
${ }^{25}$ AR 420-74.

${ }^{26}$ Technical Note (TN) 420-74-2, Facilities Engineering, Natural Resources Management, Endangered Species Management Requirements on Army Installations (U.S. Army Engineering and Housing Support Center [USAEHSC], 17 November 1989). 27 54 FR 7542 (February 1989).
} 
species problems at the installation level will help to head off controversy and will place the Army in a better position to deal with public scrutiny of its land and wildlife management programs. Third, affirmative obligations under the Act and under DOD Directive 4700.4 appear to mandate a proactive policy. Fourth, the Army will be in a much better position to develop realistic endangered species management plans that give adequate consideration to its unique land use needs if it has access to the best information possible regarding endangered species on its lands. Finally, the Act provides sufficient planning flexibility (e.g., incidental take permits, informal consultation) that can be used to accommodate both the needs of listed species and the Army training mission.

Failure to comply with the Endangered Species Act can have serious consequences. It will delay or halt ongoing or proposed activities, and may result in substantial civil and criminal penalties. The latter include fines of up to $\$ 50,000$ and imprisonment for up to 1 year for each violation. Recent criminal prosecutions indicate that responsible federal managers can be held personally liable for such environmental violations occurring on their installations.

\section{Integrated Training Area Management}

The U.S. Army's Integrated Training Area Management (ITAM) Program was developed to blend a wide variety of natural resources management considerations into a consolidated program for decisionmaking and policymaking at all levels with the Army, and to provide a vehicle for institutionalizing such considerations within the Army system. One element of the program requires standardized land inventory and monitoring of installation natural resources - the Land Condition Trend Analysis (LCTA) Program. Implementation of LCTA has resulted in the discovery of threatened, endangered, and candidate species ${ }^{28}$ and the rediscovery of species thought have become extinct. Endangered species status reports have been completed in conjunction with this work. ${ }^{29}$ These reports follow guidelines recommended by Henifin $^{30}$ and others and endorsed by the U.S. Fish and Wildlife Service. ${ }^{31}$

Endangered species data obtained in conjunction with LCTA work and other related data are being input to a computerized database of protected species on Army lands. This database is being developed as part of the LCTA Database Management System. It is being designed to incorporate database information available through the U.S. Fish and Wildlife Service, the Nature Conservancy, and state Natural Heritage programs.

\footnotetext{
${ }^{28}$ K.A. Schulz, R.B. Shaw, and D.J. Tazik. Status of Haplopappus fremontii A. Gray subsp. monocephalus (A. Nels.) H.M. Hall (Asteraceae) on the U.S. Army Pinon Canyon Manuerver Site, Colorado. Phytologia submitted. 1991.

${ }^{29}$ G.H. Aplet, et al., A Preliminary Status Report for Haplostachys haplostachya (A. Gray) St. John, an Endangered Mint Restricted to Pohakuloa Training Area, Hawaii. USACERL Draft Status Report; C.F. Bagley, and J.D. Mastrogiuseppe, Columbia Milkvetch, Astragulus columbianus Barneby on Yakima Firing Center, Washington, USACERL Draft Status Report; R.J. Brozka, Todson's Pennyroyal, Hedeoma todsenii Irving on White Sands Missile Range, New Mexico, USACERL Draft Status Report; and K.A. Schulz, R.B. Shaw and D.J. Tazik.

${ }^{30}$ M.S. Henifin, et al., "Guidelines for the Preparation of Status Reports on Rare or Endangered Plant Species," Rare Plant Conservation: Geographical Data Organization, L.E. Morse and M.S. Henefin, Eds. (The New York Botanical Garden, New York, 1981).

${ }^{31} 50$ FR (188): 39526-39527, "Endangered and Threatened Wildlife and Plants; Review of Plant Data for Listing as Endangered or Threatened Species; Notice of Review."
} 


\section{INSTALLATION ACCOUNTS}

The 46 installations listed in this report include 18 Army Materiel Command (AMC), 10 Training and Doctrine Command (TRADOC), 9 Forces Command (FORSCOM), 6 National Guard Bureau (NGB), and 1 each of Military Department of Washington, U.S. Military Academy, and Military Traffic Management Command. They encompass over 2 million acres of land ranging in size from 3,364 acres at Fort Lee, VA to over 200,000 acres at Fort Stewart, GA.

A total of 289 state and federal candidate, proposed and threatened and endangered species were identified as possibly occurring on one or more of these installations. They account for 993 records when combining the possibilities for all installations (see Appendixes A and B). Included are 86 birds (543 records), 24 mammals (143 records), 38 reptiles (93 records), 17 amphibians ( 25 records), 36 fish ( 57 records), 72 mollusks ( 115 records), 2 crustaceans ( 2 records), and 14 insects (15 records). However, several of these species are extinct throughout most if not all of their respective ranges (extirpated), most notably Bachman's warbler, ivory-billed woodpecker, and red wolf, and together these account for 78 records. Also, 247 records are for species that only migrate or are transient through an area. Removing records of extirpated, migratory, and transient species leaves a total of 264 species and 681 records.

A total of 71 species are federally threatened or endangered, federally threatened due to similarity of appearance, or proposed for federal listing. The remainder are listed or proposed for listing at the state level. Of 61 species currently known to reside on one or more installations, only 28 are listed or proposed for listing at the federal level.

Installation land managers should prepare individual installation accounts and update them annually to incorporate new information as it becomes available, and to ensure that MACOM and DA natural resources personnel have access to the most current information on threatened and endangered species on Army lands. Appendix C contains a sample standard status report. Installations should report on the status of protected species known or thought to occur on their lands through their MACOMs. This information should then be made available to the ITAM Support Center for incorporation into annual updates of the installation accounts and the LCTA Database Management System.

\section{Codes found in following text:}

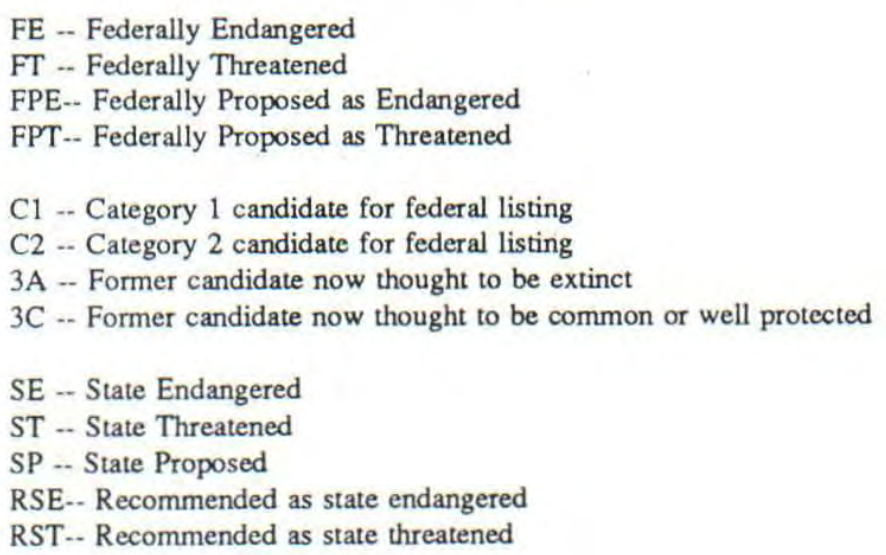

A given species may occur on more than one installation, thus yielding multiple records for many species as listed in Appendixes $\mathrm{A}$ and $\mathrm{B}$. 


\section{ABERDEEN PROVING GROUND AMC

Main Counties: Harford, Baltimore

Surrounding Counties: Cecil, Kent (across Chesapeake Bay)

\section{VERTEBRATES}

\section{Birds}

Kirtland's warbler, Dendroica kirtlandii (FE): An occasional migrant throughout the state, this warbler may be seen on the installation.

American peregrine falcon, Falco peregrinus anatum (FE, SE): Found as a migrant throughout the state, this species may be seen on the installation. Although a program for the reintroduction of falcons was implemented at Aberdeen, this has been discontinued due to the heavy predation by Great Horned owls.

Arctic peregrine falcon, Falco peregrinus tundrius (FT, SE): This falcon may be seen as a migrant on the installation. Although this falcon usually migrates along the coast, it may be seen throughout the state.

Bald eagle, Haliaeetus leucocephalus (FE, SE): The eagle is known to occur on the installation. The mid-winter count for bald eagles in 1988 was 101.

Migrant loggerhead shrike, Lanius ludovicianus migrans (C2, SE): A rare and local breeder and uncommon wintering species in the area, the shrike may be seen on the installation.

\section{Reptiles}

Atlantic loggerhead turtle, Caretta caretta caretta (FT, ST): Immature loggerheads forage in Chesapeake Bay. The occurrence of loggerheads in waters around the installation is possible. These turtles usually are seen from May to October.

Bog turtle, Clemmys muhlenbergi (C2): In 1978, there was an unconfirmed report that a bog turtle was on the Aberdeen Area of the installation. The turtle has been found on Blossom Point to the south of the installation.

\section{Mammals}

Eastern small-footed bat, Myotis sublatus leibii (C2): This bat may be seen anywhere in the state during migration. Its occurrence on the installation is possible.

Indiana bat, Myotis sodalis (FE, SE): The bat may be found in Baltimore and Harford Counties. 


\section{Amphibians}

Hellbender, Cryotobranchus alleganiensis (C2, SE): The hellbender may be found within the range of the installation.

Fish

Shortnose sturgeon, Acipenser brevirostrum (FE): This fish is a rare visitor to the Chesapeake bay watershed.

Maryland darter, Etheostoma sellare (FE, SE): This species is known to occur on the installation. The darter is found in Deer Creek. Critical habitat areas recommended by the U. S. Fish and Wildlife Service include Deer Creek, downstream of Maryland Route 136 to the confluence of Deer Creek and Susquehanna River. This portion of the Creek flows past the Churchville Test Area.

\section{Endangered Species Summary}

The bald eagle and Maryland darter are known to occur on the installation. Peregrine falcons and Kirtland's warbler may be seen as migrants. The Atlantic loggerhead turtle, and the shortnose sturgeon may be found in waters around the installation. The bog turtle may be in waters on the base. The Indiana and eastern small-footed bats may migrate through areas of the installation. The loggerhead shrike is a rare breeder and wintering species in the area. The hellbender is another possible species to be found in water areas of the installation. 


\section{ANNISTON AD AMC $\quad 18,080$ Acres $\quad$ Alabama}

Main County: Calhoun

Surrounding Counties: Cherokee, Clay, Cleburne, Etowah, St. Clair, Talladega

\section{VERTEBRATES}

\section{Birds}

American peregrine falcon, Falco peregrinus anatum (FT, ST): This bird is a rare and local transient in Alabama and migrates mainly along the Gulf Coast. Occurrence on the installation is unlikely but possible.

Arctic peregrine falcon, Falco peregrinus tundrius (FT, ST): This bird is also a rare and local transient that migrates mainly along the Gulf Coast. Occurrence on the installation is unlikely but possible.

Southern bald eagle, Haliaeetus leucocephalus leucocephalus (FE, SE): Although there are no records of this species on the installation, there is a record from Cherokee County. Because the birds may range widely to forage, an occurrence on or near the installation is possible.

Red-cockaded woodpecker, Picoides borealis (FE, SE): This species occurs within Calhoun County and could occur within the installation if suitable pine stands were available.

Appalachian Bewick's wren, Thryomanes bewickii altus (ST): In Alabama this bird was formerly an uncommon summer resident and uncommon to fairly common wintering species. Occurrence on the installation is possible, particularly in winter.

Bachman's warbler, Vermivora bachmani (FE, SE): This species was once a rare spring transient in central to northem Alabama. The bird has not been seen in the mountain region of north-central Alabama since the late 1950 s and is thought to be extinct.

\section{Mammals}

Red wolf, Canus rufus gregoryi (FE): Although this species is extirpated in Alabama, the installation is within its historic range.

Florida panther, Felis concolor coryi (FE, SE): Although this species is probably extirpated in Alabama, the installation is within its historic range. Wild populations still exist, making the occurrence of this species possible, although unlikely.

Gray bat, Myotis grisescens (FE, SE): Although there are no records of this species, summer roosts are established near water, and this installation is within the historic range. Important caves for hibernating bats occur within a $100 \mathrm{~km}$ of the installation. The bats may be seen foraging or migrating around the installation.

Indiana bat, Myotis sodalis (FE, SE): Occurrence of this species is listed as possible in Calhoun and the six surrounding counties. "Maternity" colonies could occur around dead trees within riparian areas. 
Important caves for hibernating bats occur within a $100 \mathrm{~km}$ of the installation. The bats may be seen foraging or migrating around riparian areas of the installation.

\section{Fish}

Pygmy sculpin, Cottus pygmaeus (FT, ST): This species is only known within nearby Coldwater Spring, which is located outside the city of Anniston and within $3.2 \mathrm{~km}$ of the installation.

Coldwater darter, Etheostoma boschungi (C2): This fish is known to occur in Coldwater Spring (1.3 km from the installation) and other areas of the upper Coosa River System.

Blue shiner, Notropis caeruleus (C2): Populations occur in Shoal and Chocolocco Creeks in Calhoun County.

\section{INVERTEBRATES}

\section{Mollusks}

Upland combshell, Epioblasma metastriata (C2): Records exist for Chocolocco Creek, $11.0 \mathrm{~km}$ southwest of Eastaboga, AL and the Coosa River, $4.8 \mathrm{~km}$ southeast of Ragland, AL. These areas are less than 6.2 $\mathrm{km}$ from the installation, however, no specimens were found in a 1971-1973 study.

Fine-lined pocketbook, Lampsilis altilis (C2): This species was found in Chocolocco Creek, $11.0 \mathrm{~km}$ southwest of Eastaboga, AL and $5.8 \mathrm{~km}$ south of Lincoln, AL. These areas are less than $6.2 \mathrm{~km}$ from the installation, and live specimens were found in the Coosa River drainage in a 1971-1973 study.

Judge Tait's mussel, Pleurobema taitianum (FE): Historical records indicate this species occurred within the Coosa River drainage about $6.9 \mathrm{~km}$ from the installation, although 1971-73 studies failed to find live specimens.

\section{Other}

Alabama livebearing snail, Tulotoma magnifica (C2): Historical records show this species was collected along the Coosa River drainage. It still may occur on Chocolocco Creek. It has been listed as occurring in St. Clair and Talladega counties.

Sculpin snail, Stiobia nana (C2): This species is found in Coldwater Spring, Calhoun County, $1.3 \mathrm{~km}$ from the installation.

\section{Endangered Species Summary}

Presently the pygmy sculpin and the coldwater darter are of concern within the area. The blue shiner and red-cockaded woodpecker also exist within the area. Possible occurrences of the Indiana bat should also be monitored. Bald eagles may occur as winter residents. 


\section{CAMP ATTERBURY NGB 33,500 Acres Indiana}

Main Counties: Bartholomew, Brown, Johnson

Surrounding Counties: Decatur, Jackson, Jennings, Shelby, Marion, Monroe, Morgan

\section{VERTEBRATES}

Birds

Bachman's sparrow, Aimophila aestivalis (C2, SE): Historically recorded in Brown, Jackson, and Monroe Counties, this bird is a very rare and local summer resident. Its occurrence on the installation is possible.

Henslow's sparrow, Ammodramous henslowii (ST): An uncommon summer resident and migrant, locally common, this sparrow nested in Monroe County in 1981. Its occurrence on the installation is possible.

Upland sandpiper, Bartramia longicauda (SE): A fairly common migrant in the area, recent nesting records (1984) were recorded in Johnson County. Historically, the bird also nested in Morgan County. The occurrence of the sandpiper on the installation is possible.

American bittern, Botaurus lentiginosus (SE): A fairly common regular migrant, there is a historical record of this bird nesting in Morgan County. Its occurrence on the installation in marshland areas is possible:

Great egret; Casmerodius albus (SE): A species that declined mainly because of overhunting, the egret is a rare spring migrant and uncommon fall migrant most often seen in its post-breeding wandering period, August to September. Recent nesting records (1984) are from Jennings County. Its occurrence on the installation in marsh areas is possible.

Northern harrier, Cirus cyaneus (ST): An uncommon migrant and rare permanent resident, the harrier is known to occur on the installation. Historically, this bird nested in Jackson and Johnson Counties.

Sedge wren, Cistothorus platensis (ST): A locally common migrant and summer resident, the wren historically nested in Monroe County. Its occurrence on the installation is possible.

American peregrine falcon, Falco peregrinus anatum (FE, SE): A very rare to casual migrant and winter resident, the falcon was recorded at the Atterbury Fish and Wildlife Area in 1985. Its occurrence as a migrant on the installation is possible.

Northern bald eagle, Haliaeetus leucocephalus alascanus (FE, SE): Recorded in March of 1984 on the Atterbury Fish and Wildlife Area, the eagle is usually seen during migrations.

Migrant loggerhead shrike, Lanius ludovicianus migrans (C2, SE): A rare migrant and very rare summer resident, the shrike has been recorded within a $1.3 \mathrm{~km}$ radius of the installation. Historical breeding localities are known for Jackson and Morgan Counties.

Black-crowned night heron, Nycticorax nyctiocorax (SE): This bird is known to occur on the installation. Historically recorded as nesting in Jackson County, this bird is now considered a rare migrant and casual winter resident. It may be found in marsh areas of the installation. 
Yellow-crowned night heron, Nycticorax violaceus (SE): A casual to rare migrant and summer resident, this bird was recorded nesting in Jackson County in 1986. Its occurrence in marsh areas of the installation is possible.

Osprey, Pandion haliaetus (SE): A rare to uncommon migrant throughout Indiana, this bird was recorded nesting in Morgan County in 1962. Its occurrence on waters around the installation is possible.

King rail, Rallus elegans (SE): An uncommon migrant and summer resident, this bird occurs on the installation.

Bewick's wren, Thryomanes bewickii (SE): Historically recorded as nesting in the area, this rare summer resident is often confused with the house wren. Its occurrence on the installation is possible.

Common barn owl, Tyto alba (SE): A permanent resident in various areas of the state, the barn owl may be found on or near the installation in man-made structures such as barns or storage buildings. This owl has nested in Johnson County during 1985.

Golden-winged warbler, Vermivora chrysoptera (SE): An uncommon to rare migrant throughout the state and a very rare summer resident, this bird historically was recorded nesting in Brown County. Its occurrence on the installation is possible.

\section{Reptiles}

Kirtland's snake, Clonophis kirtlandii (C2, ST): Historically, this species was recorded in Brown, Johnson, Morgan, and Monroe Counties. Its occurrence on the installation is possible.

\section{Mammals}

Bobcat, Felis rufus (SE): The bobcat is found within a $1.3 \mathrm{~km}$ radius of the installation. Historically recorded in Jennings County.

Gray bat, Myotis grisescens (FE, SE): A rare postbreeding wanderer in Indiana, the species has been recorded in Jennings County. Its occurrence on the installation is possible.

Indiana bat, Myotis sodalis (FE, SE): Generally seen in the fall, this species has been recorded in Johnson and Jennings Counties. Its occurrence as a migrant on the installation is possible.

Evening bat, Nycticeius humeralis (SE): An uncommon summer resident throughout Indiana, this species has been recorded in Jackson and Monroe Counties. Its occurrence on the installation is possible.

Badger, Taxidea taxus (ST): The badger is known to occur on the installation.

\section{Fish}

Eastern sand darter, Ammocrypta pellucida (C2): This species may be found in waters around the installation. 


\section{INVERTEBRATES}

\section{Mollusks}

Pink papershell mussel, Potamilus laevissima (SE): This mollusk has been recorded within a $1.3 \mathrm{~km}$ radius of the installation.

\section{Endangered Species Summary}

No federally listed species are known to occur on the installation, although the Indiana and gray bats may possibly forage in riparian areas on the installation. The king rail, black-crowned night heron, northern harrier, and the badger are state listed species known to occur on the installation. The loggerhead shrike, bobcat, and pink papershell mussel are known to occur within a $1.3 \mathrm{~km}$ radius. Other state listed birds may occur as migrants, and the eastern sand darter may be found in waters around the installation. 
BADGER AAP

Main County: Sauk

Edge County: Columbia

Surrounding Counties: Dane, Iowa, Richland

\section{1,637 Acres Wisconsin}

\section{VERTEBRATES}

Birds

Red-shouldered hawk, Buteo lineatus (ST): This hawk has been recorded in areas less than $6.2 \mathrm{~km}$ from the installation.

Great egret, Casmerodius albus (ST): The egret has been recorded in areas less than $6.2 \mathrm{~km}$ from the installation.

Piping plover, Charadrius melodius (FE): The plover has been recorded in Dane County from July to August. Its occurrence as a migrant on the installation is possible.

Cerulean warbler, Dendroica cerulea (ST): This species may occur on the installation as a migrant.

Yellow-throated warbler, Dendroica dominica (SE): Recorded in Dane, Iowa, and Sauk Counties from April to June, this bird may occur as a migrant.

Acadian flycatcher, Empidonax virescens (ST): The flycatcher may occur as a migrant on and around the installation.

American peregrine falcon, Falco peregrinus anatum (FE): This falcon may breed in Sauk County. Historically recorded in areas around the installation, falcons have been reintroduced to areas around Devil's Lake.

Arctic peregrine falcon, Falco peregrinus tundrius (FT): This falcon may be seen as a migrant on or around the installation, although their occurrence would be rare.

Northern bald eagle, Haliaeetus leucocephalus alascanus (FT, ST): Eagles are known to winter in riparian areas in Sauk County.

Worm-eating warbler, Helmitheros vermivorus (SE): This bird may be found in Dane County in May and Sauk County from May to July. Its occurrence on the installation is possible.

Migrant loggerhead shrike, Lanius ludovicianus migrans (C2, SE): Historically recorded less than $6.2 \mathrm{~km}$ from the installation, shrikes are usually found in open areas. Their occurrence on Badger AAP is possible.

Kentucky warbler, Oporornis formosus (ST): This warbler may occur as a migrant on and around the installation.

Osprey, Pandion haliaeetus (SE): This bird may occur as a migrant in riparian areas on the installation. 
Caspian tem, Sterna caspia (SE): This species may occur as a migrant in riparian areas of the installation.

Forster's tem, Sterna forsteri (SE) This species may occur as a migrant in riparian areas on the installation.

Common barn owl, Tyto alba (SE): Although recorded in areas greater than $9 \mathrm{~km}$ from the installation, the owl's occurrence on the grounds is possible.

\section{Reptiles}

Wood turtle, Clemmys insculpta (ST): Restricted to forested areas along fast-moving streams, and found in rivers in the fall, this species has been recorded in the Baraboo River, in areas about $6.2 \mathrm{~km}$ from the installation.

Blanding's turtle, Emydoidea blandingi (ST): This species occurs in the Wisconsin River. Its occurrence in waters around the installation is possible.

Westem slender glass lizard, Ophisaurus attenuatus attenuatus (SE): A rare species, the lizard is generally found in oak savannas and sand prairies. From 1973-1985, they were recorded in areas about $6.2 \mathrm{~km}$ from the installation. This lizard may occur on or around the installation.

Eastern massasauga rattlesnake, Sistrurus catenatus catenatus (C2, SE): Historically ranging over the southern third of Wisconsin, these snakes were recorded in areas 9-12.5 km northeast of the installation. Massasaugas are found in mesic prairies and lowland areas along rivers, lakes, and marshes. Their occurrence around the installation is possible.

Westem box turtle, Terrapene ornata (SE): Found within the sandy floodplain of the Wisconsin River, this species has been recorded in waters downstream from the installation. Its occurrence on the installation is possible.

Northem ribbon snake, Thamnophis sauritus (SE): Recorded within a $9.4 \mathrm{~km}$ radius, this species may be found in semiaquatic habitats on the installation.

Western ribbon snake, Thamnophis proximus proximus (SE): Found in isolated populations in the southern third of Wisconsin, this snake may be found in sandy areas near marshes along the Wisconsin River.

\section{Amphibians}

Blanchard's cricket frog, Acris crepitans blanchardi (SE): The installation is within the range of this frog, which inhabits marshes along rivers and river floodplains. This species has been collected in areas 12.5 $\mathrm{km}$ from Badger AAP.

Fish

Lake sturgeon, Acipenser fulvescens (C2): Uncommon to rare, the sturgeon historically was recorded in the Wisconsin River near the installation. Its occurrence is possible, but would be rare. 
Blue sucker, Cycleptus elongatus (C2, ST): Generally found in moderate to swift current, the sucker has been recorded in the Wisconsin River less than $3.1 \mathrm{~km}$ from the installation.

Goldeye, Hiodon alosoides (SE): Generally found in quiet, turbid waters, the goldeye was recorded in the Wisconsin River near the installation in 1985.

Speckled chub, Hybopsis aestivalis (ST): Generally an inhabitant of medium to large rivers, this fish has been found in the Wisconsin River around the installation.

Redfin shiner, Notropis umbratilis (ST): Locally rare to common, historically, the shiner was found in waters less than $6.2 \mathrm{~km}$ from the installation. Since it has disappeared from many of its former locales, its occurrence around the installation is unlikely.

Paddlefish, Polydon spathula (3C, ST): This species has been found in the Wisconsin River around the installation.

\section{INVERTEBRATES}

\section{Mollusks}

Rock pocketbook, Arcidens confragossus (ST): Collected in the Wisconsin River less than $6.2 \mathrm{~km}$ from the installation in 1975, this species may still occur in waters around Badger AAP.

Winged mapleleaf, Quadrula fragosa (3C, SE): Collected in waters less than $6.2 \mathrm{~km}$ from the installation in 1987, this species may still occur in waters around the base.

Salamander mussel, Simpsonaias ambigua (C2, ST): Collected in the Wisconsin River about $9.4 \mathrm{~km}$ from the installation in 1987, this species may still occur in the area.

Buckhorn, Tritogonia verrucosa (ST): Collected in 1977 less than $6.2 \mathrm{~km}$ downstream in the Wisconsin River, it may still be found in waters around the installation.

\section{Other Invertebrates}

Silphium borer moth, Papaipema silphii (SE): Collected less than $12.5 \mathrm{~km}$ from the base in 1983, the moth may occur on the installation.

\section{Endangered Species Summary}

Although no federally listed species are known to occur on the installation, the bald eagle may inhabit areas around Badger AAP. State and federally listed mollusks may be found in the Wisconsin River around the installation. Several state listed birds, fish, reptiles, and amphibians may be found in the marsh areas of the installation. 


\section{FORT A.P. HILL FORSCOM $\quad \mathbf{8 8 , 7 6 0}$ Acres Virginia}

Main Counties: Caroline and a small section of Essex

Surrounding Counties: Essex, King George, Spotsylvania, Stafford

\section{VERTEBRATES}

\section{Birds}

Henslow's sparrow, Ammodramous henslowii (RSE): Found in low wetland areas covered with brush and sedges, and sometimes in clearings, this bird historically bred in eastern Virginia. Its occurrence on the installation is possible.

Northern harrier, Circus cyaneus (RSE): Historically recorded as an uncommon migrant, this species may be seen as a transient on the installation.

American peregrine falcon, Falco peregrinus anatum (FE, SE): A migrant mainly along the coast, falcons may be seen in migration.

Bald eagle, Haliaeetus leucocephalus (FE, SE): There have been numerous sightings of adult eagles and a few immature birds on post where many ponds provide foraging opportunities. Active nests occur along the nearby Rappahannock River from Fredricksburg to the Chesapeake.

Migrant loggerhead shrike, Lanius ludovicianus migrans (C2, SE): The shrike is known to occur on the installation.

Yellow-crowned night heron, Nycticorax violaceus (RST): An uncommon summer resident of the coastal plain, and rare in winter; may be seen on the installation.

\section{Reptiles}

Bog turtle, Clemmys muhlenbergi (C2, SE): This species may occur on the installation. The turtle is usually found in bogs, swamps, and clear, slow streams with muddy bottoms.

\section{Endangered Species Summary}

Bald eagles occur as transients on the installation. Peregrine falcons may be seen as rare transients. The state listed loggerhead shrike is known to occur on the installation. Henslow's sparrow as well as the northern harrier may be seen as transients. Bog turtles may be found in pond or slow streams of the installation. 


\section{FORT BELVOIR}

MDW

9,939 Acres Virginia

Main County: Fairfax

Surrounding Counties: Fauquier, Louden, Prince William, Stafford, VA; Prince Georges and Charles, MD

\section{VERTEBRATES}

\section{Birds}

Henslow's sparrow, Ammodramous henslowii (RSE): Found in low wetland covered with brush and sedges and sometimes in clearings, this bird historically bred in eastern Virginia. Nesting was recorded in 1979 in Louden County.

Northern harrier, Circus cyaneus (RSE): Historically recorded as an uncommon migrant, this species may be seen on the installation.

American peregrine falcon, Falco peregrinus anatum (FE, SE): A migrant along the coast, the falcon may be seen on the installation.

Bald eagle, Haliaeetus leucocephalus (FE, SE): A major eagle roost occurs south of the installation on Mason Neck. Waters adjacent to the installation provide significant feeding areas. Several eagles have been observed foraging along these areas. An active nest site is located on the Accotink Wildlife Refuge, a reserve area for wildlife management on the fort.

Migrant loggerhead shrike, Lanius ludovicianus migrans (C2, SE): Historically recorded to breed in the area, the shrike may be seen on the installation.

Yellow-crowned night heron, Nycticorax violaceus (RST): An uncommon summer resident of the Coastal plain, and rare in the winter, this species may be seen on the installation.

Bachman's warbler, Vermivora bachmanii (FE, SE): Considered the rarest warbler in North America, this bird was historically reported in Virginia. Although no nests were recorded in the state, sightings were recorded in 1954 and 1958 at the mouth of Pohick Creek.

\section{Reptiles}

Wood turtle, Clemmys insculpta (RST): One adult was observed on the installation in 1988. Although often found near water, this species may wander through the weeds and meadows, and across open fields.

\section{Mammals}

Pygmy shrew, Microsorex hoyi winnemana (C2): This species was historically collected from an area less than 15 miles north from the installation. Forty-five specimens have been captured on the fort since 1987, all south of Route 1 . 


\section{Endangered Species Summary}

Adult and immature bald eagles are known to use the installation for foraging. An eagle nest site has also been observed. The wood turtle is also known to occur on the installation. The peregrine falcon may be seen as a rare transient. The rare Bachman's warbler was historically recorded in the area, although this species may be extinct. State species of concern which may be seen on the installation include Henslow's sparrow, northern harrier and loggerhead shrike. The pygmy shrew has recently been documented. 


\section{FORT BENNING TRADOC 18,1618 Acres Georgia}

Main Counties: Muscogee, Chattahoochee, GA; Russell, AL

Edge Counties: Marion, Talbot

Surrounding Counties: Harris, Stewart, Webster

\section{VERTEBRATES}

Birds

American peregrine falcon, Falco peregrinus anatum (FT, SE): This falcon is a migrant through Georgia, and its occurrence on the installation is possible.

Arctic peregrine falcon, Falco peregrinus tundrius (FT): This falcon is a migrant through Georgia, and its occurrence on the installation is possible.

Southern bald eagle, Haliaeetus leucocephalus leucocephalus (FE, SE): Bald eagles are transitory in Muscogee and Chattahoochee Counties. Their occurrence around the installation is possible, and they would most likely be found foraging around the Chattahoochee River and Upatoi Creek.

Wood stork, Mycteria americana (FE): This species may occur in Russell County, Alabama. The birds may travel up to $50 \mathrm{~km}$ from where they nest to feed. Falling water levels with high concentrations of fish are ideal foraging conditions, and the storks may be found within or around the installation if such conditions exist.

Red-cockaded woodpecker, Picoides borealis (FE, SE): The second highest (may be highest in 1990) number of red-cockaded woodpeckers in the state of Georgia are present on the installation. As many as 65 to 70 colony sites are present.

Appalachian Bewick's wren, Thryomanes bewickii altus (C1, ST): Historically a locally common winter resident in the area, this bird may occur on the installation.

\section{Reptiles}

American alligator, Alligator mississipiensis (FTSA): This species occurs throughout the state and is found on the installation in swamp or riverine areas. Alligators have been recorded in Upatoi Creek and many man-made ponds on the post.

\section{Mammals}

Red wolf, Canus rufus gregoryi (FE): Although this species is extirpated in Alabama and Georgia, the installation is within its historic range. 
Indiana bat, Myotis sodalis (FE, SE): The bat may be found in Chattahoochee and edge counties, and Russell County, Alabama. Although hibernacula probably do not occur near the installation, the bats may be found individually while foraging or migrating.

Florida panther, Felis concolor coryi $(\mathrm{FE})$ : Although a very rare transient in Georgia, this species was once found throughout the state. Wild populations still exist, making its occurrence on the installation possible, but unlikely.

Eastern cougar, Felis concolor cougari (FE, SE): Although a very rare transient in Georgia, this species was once found throughout the state. Its occurrence on the installation is possible, but unlikely.

Fish

Bluestripe shiner, Notropis callitaenia (C2): This is a large stream species historically collected in the Chattahoochee River drainage. Its occurrence in waters around the installation is possible.

\section{INVERTEBRATES}

\section{Mollusks}

Lined pocketbook, Lampsilis binomata (C2): This species was found in the Chattahoochee River at Columbus, which is less than $6.2 \mathrm{~km}$ from the installation.

Shiny-rayed pocketbook, Lampsilis subangulata (C2): This species was recorded from Uchee Creek, at Fort Mitchell, Alabama, which is less than $3.1 \mathrm{~km}$ from the installation.

Oval pigtoe, Pleurobema pyriforme (C2): This species was found in the Chattahoochee River in Columbus, which is less than $6.2 \mathrm{~km}$ from the installation.

Albany snail, Goniobasis albanyensis (C2): This species was recorded from Fort Mitchell, Russell County, Alabama, which is less than $3.1 \mathrm{~km}$ from the installation. It also was found in Uchee Creek, $3.8 \mathrm{~km}$ northeast of Seale, Alabama, less than $6.2 \mathrm{~km}$ from the installation.

\section{Endangered Species Summary}

The red-cockaded woodpecker and American alligator are the only federally listed species known to exist on the installation. The bald eagle, wood stork, Indiana bat, and Peregrine falcon may use the installation for wintering, feeding areas, or during migration. Several candidate species for federal listing are known from the area, including Bewick's wren. bluestripe shiner, and several mollusks. 

CAMP BLANDING
NGB
72,397 Acres
Florida

Main County: Clay

Surrounding Counties: Baker, Bradford, Duvall, Putnam, St. Johns

\section{VERTEBRATES}

Birds

Florida Scrub Jay, Aphelocoma coerulescens coerulescens (FT, ST): This bird is known from Clay and Putnam Counties. There are records of occurrences on the installation.

American ivory-billed woodpecker, Campephilus principalis principalis (FE, SE): Formerly found throughout the state of Florida, this bird was probably last sighted in the early 1950s and is thought to be extinct.

American peregrine falcon, Falco peregrinus anatum (FT, SE): This falcon winters throughout Florida, making its occurrence on the installation possible.

Arctic peregrine falcon, Falco peregrinus tundrius (FT): This falcon winters throughout Florida, making its occurrence on the installation possible.

Southeastern American kestrel, Falco sparverius paulus (C2, ST): At least one pair has been reported on the installation.

Southern bald eagle, Haliaeetus leucocephalus leucocephalus (FE, ST): Eagles are known from Clay, Bradford, Putnam and St. Johns Counties. Although there may not be suitable nesting habitat, these birds may forage around or on Kingsley Lake.

Wood stork, Mycteria americana (FE, SE): Storks are recorded in Clay and surrounding counties. The birds may travel to feeding areas as far as $50 \mathrm{~km}$ from where they nest. Falling water levels with high concentrations of fish are ideal feeding conditions, and the birds may be found within or around the installation if such conditions exist.

Red-cockaded woodpecker, Picoides borealis (FE, ST): Several active colonies have been recorded on the base. Colonies are found in mature pine stands a minimum of 60 years in age.

Bachman's warbler, Vermivora bachmanii (FE, SE): Historically recorded wintering in and migrating through Florida, this species is now considered the rarest warbler in North America. The installation is within its historic range.

\section{Reptiles}

American alligator, Alligator mississipiensis (FTSA): Because the alligator is found in freshwater areas throughout the state, its occurrence at Kingsley Lake is likely. 
Eastem indigo snake, Drymarchon courais couperi (FT, ST): This species is found within Clay County and there are unconfirmed records of occurrence on the installation. Since this species is often found in the burrows of Gopher tortoise, which do occur on the camp, the occurrence of the indigo snake species is also likely.

Gopher tortoise, Gopherus polyphemus (C2): This species is known to occur on the installation.

\section{Amphibians}

Gopher frog, Rana areolata (C2): Known to occur in Clay County, this species also has been recorded on the installation.

\section{Mammals}

Red wolf, Canis rufus gregoryi (FE): Although this species is extirpated in Florida, the installation is within its historic range.

Florida panther, Felis concolor coryi (FE, SE): Although this species is very rare in northem Florida, the installation is within its historic range. Occurrence on the installation is unlikely but possible.

Sherman's fox squirrel, Sciurus niger shermani (C2): These squirrels are known to occur on and around the installation.

Florida black bear, Ursus americanus floridanus (C2, ST): This species is found in Clay County. Since bears have a large range, it may occur on the installation, although only temporarily.

\section{Endangered Species Summary}

The Florida scrub jay, bald eagle, and red-cockaded woodpecker, and possibly the American alligator occur within the installation. The wood stork and eastern indigo snake should also be looked for on the installation. The Arctic and American peregrine falcon may occur during migration. Candidate species found include the Southeastern American kestrel, the gopher tortoise, the gopher frog, and Sherman's fox squirrel. 


\section{FORT BRAGG FORSCOM 133,034 Acres North Carolina}

Main Counties: Hoke, Cumberland

Edge County: Moore

Surrounding Counties: Bladen, Harnett, Lee, Moore, Richmond, Robeson, Sampson, Scotland

\section{VERTEBRATES}

Birds

Bachman's sparrow, Aimophila aestivalis (C2, ST): A large breeding population (12 or more males) has been noted throughout the installation. A few also have been seen in the winter and are presumed to be year-round residents. Possible effects of pine straw harvesting on this species should be evaluated.

American ivory-billed woodpecker, Campephilus principalis principalis (FE): Although this species was found throughout the southeast, its present distribution is unknown, and it is thought to be extinct.

Kirtland's warbler, Dendroica kirtlandii (FE, SE): This species are rare transients migrating through the Carolinas. It may be seen on the installation.

American peregrine falcon, Falco peregrinus anatum (FE, SE): This bird may be found anywhere throughout the state, although its occurrence is uncommon. It is not known to nest in the area.

Arctic peregrine falcon, Falco peregrinus tundrius (FT, SE): This bird may be found anywhere throughout the state, although its occurrence is uncommon. It is not known to nest in the area.

Southem bald eagle, Haliaeetus leucocephalus leucocephalus (FE, SE): Known to occur in Richmond County, the occurrence of the bald eagle on lakes around the installation is possible.

Red-cockaded woodpecker, Picoides borealis (FE, SE): Several hundred active colonies have been recorded on the installation since 1982 .

Bachman's warbler, Vermivora bachmainii (FE) This bird once was found throughout the southeast, including the area of the installation. Its present distribution is unknown, and it is possible that it is extinct.

\section{Reptiles}

American alligator, Alligator mississippiensis (FTSA, ST): This species has been recorded in areas on and around the installation. 


\section{Mammals}

Red wolf, Canis rufus gregoryi (FE, SE): Although this species is extirpated in North Carolina, the installation is within its historic range. Captive bred wolves have been reintroduced on the Alligator River National Wildlife Refuge in northeastern North Carolina.

Eastern cougar, Felis concolor cougari (FE, SE): Although wild populations are thought to still exist, the cougar is probably extirpated in North Carolina.

Fish

Sandhills chub, Semotilus lumbee (C2): This species has been recorded in Lumber and Cape Fear drainages, which are around the installation.

\section{INVERTEBRATES}

\section{Mollusks}

Cape Fear spike pearly mussel, Elliptio marsupiobesa (C2, ST): This mussel is found in several localities in the Cape Fear River near Fayetteville. The type locality is less than $8 \mathrm{~km}$ from the installation.

\section{Endangered Species Summary}

The red-cockaded woodpecker and the American alligator are the only federally listed species known to occur on the installation. The Kirtland's warbler, peregrine falcons, and bald eagle are other federally listed species which may be transient through the area. The state listed Bachman's sparrow is known to occur on the installation. The Cape Fear spike mussel and the sandhill chub are category 2 species which may be found in waters around the installation. 


\section{FORT CAMPBELL FORSCOM 105,224 Acres Kentucky and Tennessee}

Main Counties: Trigg, Christian, KY; Stewart, Montgomery, TN

Surrounding Counties: Caldwell, Calloway, Hopkins, Lyon, Marshall, Muhlenberg,Todd, KY; Benton, Cheatham, Dickson, Henry, Houston, Robertson, TN

\section{VERTEBRATES}

\section{Birds}

Piping plover, Charadrius melodus (FT): A rare transient, the plover may be seen on shore areas of the installation. Breeding areas were recorded in Calloway County in 1982.

Common moorhen, Gallinula chloropus (KY: SE,; TN: ST): A rare transient and extremely rare winter resident, the moorhen may breed in areas on or around the installation.

Migrant loggerhead shrike, Lanius ludobicianus migrans (C2): An uncommon to fairly common resident, the shrike is found in a variety of semi-open and open habitats. It may breed in areas on or around the installation.

Cooper's hawk, Accipiter cooperii (TN: ST): Although it is rare, this hawk is considered a permanent resident throughout Tennessee. In Kentucky, it is an uncommon to common resident which breeds throughout the state. It has been recorded year round in Stewart and Montgomery Counties, Tennessee. These hawks are most likely to be seen on the installation from September through November when additional migrants from the north are present.

Sharp-shinned hawk, Accipiter striatus (TN: ST): In Kentucky, the sharp-shinned hawk is a very rare to rare resident and an uncommon to common transient. It is, however, a permanent resident which may be found anywhere in Tennessee. Recorded from Stewart and Montgomery Counties throughout the year, it may be found within the installation.

Spotted sandpiper, Actitus macularia (KY: SE): In Kentucky and Tennessee, this bird is considered a common fall and spring migrant and an occasional summer resident. It is also an uncommon to rare wintering bird. It is listed year round in Montgomery County and was recorded in Stewart County, Tennessee from April through May. Since this species is found almost anywhere near water, it may be seen on the installation.

Bachman's sparrow, Aimophila aestivalis (C2, KY: ST; TN: SE): This bird is listed as occurring in Montgomery City, Tennessee, and may nest in this area. In Kentucky this bird is a rare summer resident. Its preferred habitat includes open pastures, thick grass with low trees, open grassy woodlands and old fields.

Grasshopper sparrow, Ammodroamus savannarum (TN: ST): Observations in 1979 were recorded northwest of New Providence, less than $3.1 \mathrm{~km}$ from the installation, This species is considered a summer resident and uncommon to rare winter visitor in Kentucky and Tennessee. It may be found on the installation. 
Blue-winged teal, Anas discors (KY: SE): A common transient in Kentucky in the late spring and early fall, this species has been observed on Kentucky Lake.

Golden eagle, Aquila chrysaetos (TN: SE): An uncommon winter visitor and transient, this eagle has been recorded in Stewart County from August through February. It is a regular winter visitor at Land Between the Lakes.

Great blue heron, Ardea herodias (TN: ST): An uncommon to rare permanent resident, the Great Blue has been recorded in Stewart and Montgomery Counties year round. These birds require freshwater marsh areas for breeding and feeding.

Upland sandpiper, Bartramia longicauda (KY: SE): Historical records indicate this species was recorded during spring migration in Trigg County. This bird is a rare to uncommon transient in Kentucky.

American bittern, Botaurus lentiginosus (KY: SE; TN: SE): An uncommon permanent resident of low-lying marshy habitats, this species has been recorded in March through September in Montgomery County and October through February in Stewart County. It has also been recorded as a migrant in Trigg County. Most bitterns are observed during migration.

American ivory-billed woodpecker, Campephilus principalis principalis (FE) Although this bird is thought to be extinct, it once was found throughout the southeast. In Kentucky, the bird was recorded as a resident along the Mississippi River and the lower Ohio River. Records for these birds in Kentucky and Tennessee are sketchy, but the installation may have been within the bird's historic breeding range.

Great egret, Casmerodius albus (KY: SE): The egret is an uncommon transient and non-breeding summer visitor, and a very rare and local summer resident in Kentucky. Historically, it was recorded in Trigg County, and Kentucky Woodlands National Wildlife Refuge (NWR) in the spring. In Tennessee the egret is considered an uncommon to rare summer resident and a rare wintering bird and an uncommon transient. It was recorded April through September in Stewart County and October through March in Stewart and Montgomery Counties.

Lark sparrow, Chondestes grammacus (KY: SE): In Kentucky this bird is a rare spring transient and summer resident. It has been recorded as a fall migrant in Kentucky Woodlands NWR in Trigg County, and Hopkins and Calloway Counties. In Tennessee it is listed as an uncommon to rare and very local summer resident and nesting species, and an uncommon transient and rare wintering bird. This bird has been recorded from March through October in Montgomery County.

Northem harrier, Circus cyaneus hudsonius (TN: ST): In Tennessee and Kentucky, this bird is an uncommon to rare transient in spring and fall and an uncommon to rare winter visitor. Recorded from August to May in Stewart and Montgomery Counties, its occurrence on the installation is possible.

Little blue heron, Egretta caerulea (KY: SE): Usually found in shallow-water marshes and upland meadows, records indicate this bird was seen in Stewart and Montgomery Counties from March through mid-November. From 1981 to 1983 the little blue nested in a Black-crowned night heron colony on an island in Lake Barkley.

American peregrine falcon, Falco peregrinus anatum (FE, KY: SE; TN: SE): This falcon is an uncommon to rare transient in the spring and fall, and an extremely rare transient and winter visitor in Kentucky. It may be found on the installation. 
Arctic peregrine falcon, Falco peregrinus tundrius (FE, KY: SE; TN: SE): Listed as occurring in Trigg county, this falcon is an uncommon to rare transient in the spring and fall and is an extremely rare transient and winter resident in Kentucky. It may be seen on the installation.

American coot, Fulica americana (KY: SE): In Kentucky and Tennessee, the coot is a fairly common spring and fall migrant, and rare as a summer resident and nesting species. In Tennessee it is a common to locally abundant winter visitor. This bird has been recorded from May through September in Montgomery County and October through April in both Stewart and Montgomery Counties.

Bald eagle, Haliaeetus leucocephalus (FE, KY: SE; TN: SE): Bald eagles occur in the Land Between the Lakes area. An unsuccessful nesting attempt was made in the area in 1974. Their occurrence on the installation foraging or migrating is likely. Historically recorded as a very rare summer visitor in Kentucky (probably the southem subspecies leucocephalus). Fall and spring transients are probably both leucocephalus and the northern subspecies alascanus. Rare to fairly common winter residents historically recorded in Kentucky were thought to be subspecies alascanus, and are probably the wintering subspecies on the installation.

Least bittem, Ixobrychus exilis (KY: SE; TN: ST): An uncommon to rare transient across Kentucky and Tennessee during April and May and again in September and October, bitterns inhabit freshwater marshes and pond edges. These birds have been recorded in Stewart and Montgomery Counties from April through mid-October.

Hooded merganser, Lophodytes cucullatus (KY: SE): In Kentucky this bird is a fairly common to common transient and winter resident. It is a rare summer resident in western Kentucky and breeds locally. In winter, large flocks have been recorded from the Land Between the Lakes. Historic records indicate this bird was found during the summer in Trigg County.

Black-crowned night heron, Nycticorax nycticorax (KY: SE; TN: ST): Breeding colonies were recorded in 1984 on an Island in Lake Barkley. These birds will nest in pine stands and are usually found in marshes, swamps, creeks and wooded streams. Their occurrence as post-breeding wanderers on the installation is possible.

Yellow-crowned night heron, Nycticorax violacea (KY: ST; TN: ST): Historically this heron was found September through February in Stewart and Montgomery Counties, Tennessee. It has been recorded in Trigg county, Kentucky. Breeding was recorded in Calloway County in 1988. These herons are usually found in forested areas near swamps or sloughs, and their occurrence foraging or as post-breeding wanderers on the installation is possible.

Osprey, Pandion haliaetus (KY: SE; TN: SE): In 1986, there were active nests in Calloway and Trigg Counties. It was recorded in Lyon County in 1988. A rare and local summer resident in Tennessee, the osprey was recorded in Montgomery county from April through October. This bird is a common spring and fall migrant and rarely winters in the area. Ospreys are found around streams, lakes, and ponds. Its occurrence on or around the installation is likely.

Double-crested cormorant, Phalacrocorax auritus (KY: SE): In Kentucky the cormorant is an uncommon transient, rare winter resident, and rare nonbreeding summer visitori In Tennessee, this bird is considered an uncommon to rare wanderer which may be found most often in fall and winter. Formerly the cormorant was a common permanent resident along the Mississippi River, and on parts of Kentucky Lake. It has been recorded from September through February in Montgomery County. 
Pied billed grebe, Podilymbus podiceps (KY: SE): Recorded August through April in Stewart and Montgomery Counties, in Tennessee this species is a fairly common migrant in the spring and fall. It is a fairly common to uncommon winter visitor and a very uncommon to rare summer resident and breeding species. In Kentucky this bird is considered a fairly common to uncommon transient, a rare to uncommon winter resident, and a rare summer resident. Historical records indicate this species may have nested in Trigg County.

King rail, Rallus elegans (KY: SE; TN: SE): An uncommon to rare transient and an uncommon to rare summer resident, the rail is mainly found in marshy habitats. There is a nesting record for this species in Stewart County. This bird has also been recorded from April through July in Stewart County.

Virginia rail, Rallus limicola (TN: SE): An uncommon to rare transient and a rare winter visitor across Kentucky and Tennessee, the rail is also a rare and local summer resident. It has been recorded in Montgomery County from August through April. These birds usually breed in marshy areas. During migration and winter the birds are sometimes found in drier, brushy fields.

Bank swallow, Riparia riparia (TN: ST): An uncommon to rare local summer resident and breeding bird across Tennessee, the swallow has been recorded April through October in Montgomery County. Nesting colonies have been recorded from Lyon County. Swallows are found near water during migration and while nesting.

Interior least tem, Sterna antillarum athallassos (FE, KY: SE; TN: SE): Although this species is an uncommon to rare transient in areas away from the Mississippi River, its occurrence on the installation is possible. In Tennessee, it is considered an uncommon to rare transient and wanderer. It has been recorded in Montgomery County from late March through late September.

Appalachian Bewick's wren, Thryomanes bewickii altus (C1; TN: ST): Listed in Montgomery County, Tennessee, this species was observed less than $3.1 \mathrm{~km}$ from the installation. It is a permanent resident throughout Tennessee.

Common barn owl, Tyto alba (TN: SE): A rare to very uncommon resident in Kentucky and Tennessee, these owls are found in open rural areas as well as towns and cities. This species has been recorded in Montgomery County.

Bachman's warbler, Vermivora bachmani (FE, KY: SE): Considered the rarest warbler in North America, this bird's historical range was probably throughout the southeast. Although breeding records are sketchy, this warbler was recorded as a casual summer resident in southwestern Kentucky.

\section{Reptiles}

Alligator snapping turtle, Macroclemys temmincki (C2, KY: ST) This species inhabits the Tennessee and Cumberland Rivers and occurs on the Land Between the Lakes and in Stewart County, Tennessee. Although rare, it may be found in rivers or swampy areas in and around the installation.

Northern copperbelly water snake, Nerodia erythrogaster neglecta (C2): Listed as occurring in Montgomery County, Tennessee, this species was collected in an area less than $6.2 \mathrm{~km}$ from the installation. 
Northern pinesnake, Pituophis melanoleucus (melanoleucus) (C2; TN: ST): Listed as occurring in Montgomery County, the occurrence of this snake on the installation is possible. It is usually found in sandy pine woods or dry mountain ridges.

Western pygmy rattlesnake, Sistrurus miliarius (streckeri) (KY: ST; TN: ST): Listed as occurring in Montgomery County, the occurrence of the snake on the installation is possible. This species is usually found near water in river floodplains, swamps, or marshes, but also inhabits drier wooded uplands.

Mammals

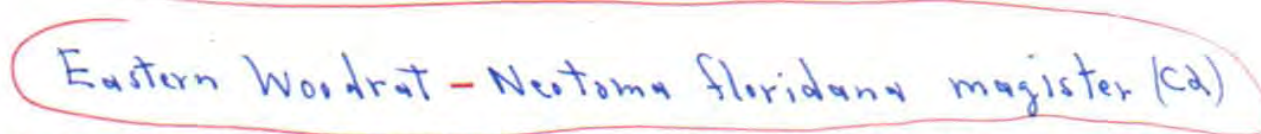

Pygmy shrew, Microsorex hoyi winnemana (C2): The pygmy shrew may be collected in areas around the installation. It has been found in various habitats, including bogs, woods, grassy fields, and brushy areas on forest edges.

Red wolf, Canis rufus gregoryi (FE): Extirpated from Tennessee and Kentucky, this species once ranged throughout the southeastem United States. Only about 40 captive individuals remain today.

Eastern cougar, Felis concolor cougari (FE, KY: SE; TN: SE): Although the cougar has been extirpated throughout most of its historical range, wild populations are thought to still exist. Listed as possibly occurring in Trigg and Lyon counties, Kentucky and Stewart County, Tennessee, the cougar's occurrence on the installation is possible.

River otter, Lutra canadensis (TN: ST): the river otter is usually found in streams, rivers, and lakes usually bordered by woods. The occurrence of the otter on the installation is possible.

Southeastern bat, Myotis austroriparius (C2; KY: SE): Listed in Christian County, Kentucky, this bat is known from a cave near Hopkinsville. These bats forage just above the surface of quiet water. Habitats used for nursery colonies are unknown. It is possible these bats may be seen foraging on the installation.

Gray bat, Myotis grisescens (FE, KY: SE; TN: SE): Known in all main counties and Caldwell and Todd Counties, the occurrence of this bat foraging on the installation is likely. Historically, nursery colonies were recorded in caves in Trigg County.

Indiana bat, Myotis sodalis (FE, KY: SE; TN: SE): This species is known to occur in Trigg County, Kentucky, and Stewart and Montgomery Counties, Tennessee, and may occur in Christian and all surrounding counties. Historical records (1965) indicate it was collected in Cooper Creek Cave (also known as Fosters Cave), $1 \mathrm{~km}$ SE of Oakwood, less than $3.1 \mathrm{~km}$ from the installation. Occurrence of foraging or migrating bats on the installation is possible.

Eastem small-footed bat, Myotis sublatus leibii (C2, KY: SE): This bat inhabits old mines and buildings, and is found under bark and beneath slabs of rocks in quarries. Listed as occurring in Montgomery County, Tennessee, little else is known of its existence.

Evening bat, Nycticeius humeralis (KY: SE; TN: ST): Uncommon summer resident ranging in the western and southern part of Kentucky, it usually is found in buildings and tree cavities.

Rafinesque's big-eared bat, Plecotus rafinesquii (C2; KY: ST): A scarce species in Tennessee, this bat usually is found roosting in unoccupied buildings or other man-made structures. Since it ranges statewide 
in Tennessee and western and eastern areas of Kentucky, it is possible this bat may be seen on and around the installation.

\section{Amphibians}

Bird-voice tree frog, Hyla avivoca (KY: ST): Historically recorded in Trigg County, this species may be found around the installation.

Hellbender, Cryptobranchus alleganiensis (C2): The hellbender is found in Stewart and Montgomery Counties, Tennessee, and Christian County, Kentucky. It was recorded from Little Fork Creek near U. S. Highway $41 \mathrm{~A}$ less than $1.3 \mathrm{~km}$ from the installation.

\section{Fishes}

Smallscale darter, Etheostoma proeliare (KY: SE): This darter has been collected from the Little River. Activities on the installation may affect habitat for this species.

Slender madtom, Noturus exilis (KY: SE): Collected from a tributary on Lake Barkley less than $1.3 \mathrm{~km}$ from Fort Campbell, this fish may be affected by activities on the installation.

Lake sturgeon, Acipenser fulvescens (C2, KY: SE; TN: SE): Listed in Stewart County, Tennessee, this species was formerly found in the main channels of the Cumberland and Tennessee Rivers. Its occurrence in the waters around the installation is possible.

Blue sucker, Cycleptus elongatus (C2; TN: ST): Listed in Stewart County, Tennessee, this species was formerly found in the Tennessee River. Its occurrence in the waters around the installation is possible.

\section{INVERTEBRATES}

\section{Mollusks}

Eastem fanshell, Cyprogenia stegaria (FPE, KY: ST): Historically collected from the Cumberland River, populations of this mollusk may still persist.

Cumberland combshell, Eproblasma brevidens (C2, SE): Historically recorded in the Cumberland River, this species may still persist in watersheds around the installation.

Yellow-blossom pearly mussel, Epiobalsma florentina (FE, KY: SE; TN: SE): Historically found in the lower Red River, this species may still persist in watersheds around the installation.

Purple catspaw pearly mussel, Epioblasma obliquata (FPE, KY: SE): This species may still persist in the Cumberland River. 
Dromedary pearly mussel, Dromus dromas (FE, KY: SE; TN: SE): This species was historically found in the main channels of the Tennessee and Cumberland Rivers. It is listed in Montgomery and Stewart Counties, Tennessee. Impoundments have made the occurrence of this species around the installation unlikely.

Tan riffle shell, Epioblasma florentia walkeri (FE, KY: SE; TN: SE): This species was found in the lower Red River in Montgomery County, Tennessee, in an area less than $9.4 \mathrm{~km}$ from the installation. Impoundments have made the occurrence of this species around the installation unlikely.

Pink mucket pearly mussel, Lampsilis abrupta orbiculata (FE, KY: SE; TN: SE): Historically recorded in Tennessee and Cumberland drainages, this species has been listed in Montgomery and Stewart Counties, Tennessee. It is known to occur in Marshall County, Kentucky. Occurrence near the installation is possible.

Golf-stick pearly mussel, Obovaria retusa (FE, KY: SE): Historically, this species was collected in Stewart County, Tennessee. It is also listed in Trigg County. Its occurrence in waters around the installation is unlikely.

Orange-footed pearly mussel, Plethobosus cooperianus (FE, KY: SE; TN: SE): Historically this species was common in the Cumberland River from Clay to Stewart Counties, Tennessee. It was also recorded in the lower Tennessee River from Hardin to Stewart Counties. It is listed as possibly occurring in Trigg County, Kentucky and Montgomery and Stewart Counties, Tennessee. Its occurrence in waters around the installation is possible.

Rough pigtoe, Pleurobema plenum (FE, KY: SE; TN: SE): This species was formerly widespread throughout the Tennessee River. In the Cumberland River, it was found from Pulaski County, Kentucky to Montgomery County, Tennessee.

Rugged river snail (muddy rocksnail), Lithasia salebrosa (C2, TN: SE): Formerly found in the lower Cumberland River from Montgomery County, Tennessee to Trigg County, Kentucky. Listed as occurring within Montgomery County.

Armored rocksnail (armigerous river snail), Lithasia armigera (C2): This species was historically recorded from the Cumberland River down to Trigg County, and may still persist in watersheds around the installation.

\section{Endangered Species Summary}

Gray and Indiana bats and the bald eagle are the only federally endangered species likely to be found in the area. The grasshopper and Bachman's sparrow, Appalachian Bewick's wren, northem copperbelly water snake, northern pinesnake, western pygmy rattlesnake, and the hellbender are state threatened or endangered species found within the vicinity of the installation. The northern harrier, Cooper's and sharp-shinned hawks, night herons, osprey, and river otter are state listed species likely to be found. Southeastern and eastern small-footed bats may be seen foraging, and the fish and mollusk species listed may be found in waters in the area. 
FORT DEVENS

Main Counties: Worcester, Middlesex

Surrounding Counties: Hampden, Norfolk

\section{VERTEBRATES}

Birds

Henslow's sparrow, Ammodramus henslowii (SE): This sparrow has been found in widely scattered areas throughout the state. It has been found in open fields with a dense growth of grass, weeds, and clover, although wet meadows may be its preferred habitat.

Upland sandpiper, Bartramia longicauda (SE): This bird has been recorded on the installation. The sandpiper is found in large expanses of grassy fields, particularly in mown grass next to airstrips.

Northem harrier, Circus cyaneus (ST): Formerly a common summer resident and a regular transient throughout Massachusetts, the harrier may be seen as a transient foraging in marsh or field areas on or near the installation.

American peregrine falcon, Falco peregrinus anatum (FE, SE): Historically wintered in a steeple in Worcester. The reestablishment of this bird to its former breeding range, including areas of Massachusetts, is in progress. The occurrence of the falcon on the installation is possible.

Arctic peregrine falcon, Falco peregrinus tundrius (FT, SE): This peregrine may migrate through the area.

Bald eagle, Haliaeetus leucocephalus (alascanus) (FE, SE) The eagle is known from Hampden, Middlesex, and Worcester Counties. Its occurrence as a transient along riparian areas or lakes around installation is possible.

Least bittern, Ixobrychus exilis (ST): This bird has been recorded at the Bolton Flats Wildlife Management area and may occur in marsh areas around the installation.

Pied-billed grebe, Podilymbus podiceps (ST): This species has been recorded at the Oxbow National Wildlife Refuge and Bolton Flats Wildlife Management Area. Historically considered a local summer resident, an uncommon spring transient, and a common fall transient, the grebe may be seen in marsh or pond areas around the installation.

\section{Reptiles}

Blanding's turtle, Emydoidea blandingii (ST): This turtle has been recorded at the Oxbow National Wildlife Refuge. It usually inhabits densely vegetated shallow ponds, marshes, or small streams. 


\section{Mammals}

Eastern cougar, Felis concolor cougari (FE) Listed as possibly occurring in Worcester County, this subspecies of the cougar may be extirpated from the area.

Eastern small-footed bat, Myotis subulatus leibii (C2): The bat's range is within the area of the installation. These bats will roost in buildings, and they may be seen foraging or migrating in areas around the installation.

Indiana bat, Myotis sodalis (FE): The bat has been collected in Hampden County and may also occur in Middlesex and Worcester Counties. It may be seen foraging or migrating through riparian areas of the installation.

New England cottontail, Sylvilagus transitionalis (C2): The cottontail has been recorded in Worcester and Middlesex Counties. They may be found in different varying habitats including beach, salt marsh, oak forest with a heavy understory, and open upland fields with little cover.

\section{Amphibians}

Marbled salamander, Ambystoma opacum (ST): The salamander is found in low areas around ponds, swamps, and quiet streams during the breeding season. Its range includes areas around the installation.

\section{Endangered Species Summary}

No federally listed species are known to occur on the installation, although the bald eagle, peregrine falcon, and Indiana bat may occur as transients. The eastem small-footed bat and the New England cottontail are candidate species that may be found in the area. The upland sandpiper is the only state listed species that is known on the installation. The least bittern, pied-billed grebe, and Blanding's turtle are known to occur less than $16 \mathrm{~km}$ from the installation. The Henslow's sparrow and northern harrier may occur as migrants or transients. The marbled salamander may be found in swampy or riparian areas around the installation. 
FORT DIX

TRADOC

31,759 Acres New Jersey

Main Counties: Burlington, Ocean

Surrounding Counties: Atlantic, Camden, Mercer, Monmouth

\section{VERTEBRATES}

\section{Birds}

Cooper's hawk, Accipiter cooperii (SE): Known to occur in the winter in Burlington and Ocean Counties, this species is found primarily in mature forests or open woodland and forest edges.

Northem goshawk, Accipiter gentilis (ST): A rare breeder, migrant, and winter visitor, the goshawk may be seen as a transient on the installation.

Grasshopper sparrow, Ammodramus savannarum (ST): Known to breed in Burlington County, this species was recorded in the area in 1987. The sparrow is found in prairie, old fields, and open grasslands. Its occurrence on the installation is possible.

Great blue heron, Ardea herodias (ST): Known year-round in Burlington County (although not recorded as breeding) and known to breed in Ocean County, this bird may be found in marsh or riparian areas of the installation.

Short-eared owl, Asio flammeus (SE): Found in open country including marshes and open woodlands, this owl may be found in Ocean County. Its occurrence on the installation is possible.

Upland sandpiper, Bartramia longicauda (SE): Known to breed in Burlington County, the sandpiper may be found in grassland areas, especially dry meadows and pastures, on or around the installation.

American bittem, Botaurus lentiginosus (ST): This species may possibly occur in Burlington and Ocean Counties. A summer and fall resident as well as breeder in the state, the bittern may be found in marsh or bog areas on or around the installation.

Red-shouldered hawk, Buteo lineatus (ST): Known as a wintering species around wooded swamps and open woodlands in Ocean County, the hawk may occur on the installation.

Piping plover, Charadrius melodus (FE, SE): Known to breed along beaches and around ponds, lakes, and impoundments in Ocean County. Its occurrence as a transient on the installation is possible.

Northem harrier, Circus cyaneus (SE): Known as a year-round resident in Burlington and Ocean Counties, the harrier may be found in marsh or grassland areas on or near the installation.

Sedge wren, Cistothorus platensis (SE): A summer and fall resident as well as a breeder in New Jersey, this species may be found in grasslands and marshes in Ocean County. Its occurrence on the installation is possible. 
Bobolink, Dolichonyx oryzivorus (ST): A fall migrant rarely found in the spring or breeding in the summer, the bobolink may be found in Burlington County. Its occurrence on the installation is possible.

American peregrine falcon, Falco peregrinus anatum (FE, SE): Known as a year-round resident in Ocean County along the coast, this species may be seen on the installation. Breeding populations are being reestablished in the state.

Arctic peregrine falcon, Falco peregrinus tundrius (FT, SE): Known as a migrant throughout the state, this species may be seen on the installation.

Cliff swallow, Hirundo pyrrhonota (SE): Artificial nest boxes have been placed on bridges of the Delaware River to help increase the population. The swallows may occur as rare migrants around riparian areas of the installation.

Migrant loggerhead shrike, Lanius ludovicianus migrans (C2, SE): Known in Ocean County during the winter, the shrike may be found in open areas with scattered trees and shrubs.

Black rail, Laterallus jamaicensis (ST): This rail is known to breed in Burlington and Ocean Counties. It may be found in marsh areas of the installation.

Red-headed woodpecker, Melanerpes erythrocephalus (ST): This species is known to occur year round in Burlington and Ocean Counties, and may be found on the installation. This bird is found in open woodland areas, especially with beech or oak and open areas with scattered trees.

Yellow-crowned night heron, Nycticorax violaceus (ST): Known to breed in marshes, swamps, and lakes of Ocean County, this heron may occur on the installation.

Osprey, Pandion haliaetus (ST): Known to breed in Burlington and Ocean Counties, the osprey may be found around riparian areas of the installation.

Savannah sparrow, Passerculus sandwichensis (ST): This species is known to occur year round in Burlington County and winters in Ocean County. It may be found on the installation in open areas, particularly grasslands and marsh areas.

Pied-billed grebe, Podilymbus podiceps (SE): Found in lakes, ponds, and marshes year round in Burlington County, the grebe has also been recorded as wintering and breeding in Ocean County. Its occurrence on the installation is possible.

Vesper sparrow, Pooecetes gramineus (SE): Known to occur year round in Burlington County, this species may be found on the installation. The sparrow is found in pastures, fields, or woodland clearings.

Eastem least tern, Sterna antillarum antillarum (FE, SE): Known to breed in Ocean County, eastern least terns may be seen as transients on riparian areas of the installation.

Barred Owl, Strix varia (ST): This species is known to occur year round in dense woodland and forest as well as swamp areas in Burlington and Ocean Counties. Its occurrence on the installation is possible. 


\section{Reptiles}

Wood turtle, Clemmys insculpta (ST): This turtle is known to occur in Burlington and Ocean Counties and was recorded in the area in 1987. It may be found in swamp or riparian areas of the installation.

Bog turtle, Clemmys muhlenbergi (C2, SE): This species is known to occur in Burlington and Ocean Counties and was recorded in the area in 1987. It may be found in swamp or riparian areas of the installation.

Timber rattlesnake, Crotalus horridus (SE): Historically known to occur in Burlington and Ocean Counties, the rattlesnake may be found on the installation. The snakes are found in wooded rocky hillsides and swampy areas.

Corn snake, Elaphe guttata (SE): Found on rocky hillsides, in meadows and riparian areas, as well as abandoned or outlying buildings, this species has been recorded in Burlington and Ocean Counties. Its occurrence on the installation is possible.

Northem pine snake, Pituophis melanoleucus melanoleucus (C2, ST): Found in lowlands, marshes, and woodland areas as well as coniferous forests and farmland areas, this species is known to occur in Burlington and Ocean Counties. Its occurrence on the installation is possible.

\section{Mammals}

Mountain lion, Felis concolor cougari (FE): Although thought to be extirpated from New Jersey, historically, the cougar was found in this area.

Small-footed bat, Myotis sublatus leibii (C2): Historically collected from a cave near Trenton, this bat may be seen as a transient on the installation.

New England cottontail, Sylvilagus transitionalis (C2): This cottontail occurs within the range of the installation and may be seen there.

\section{Amphibians}

Eastern tiger salamander, Ambystoma tigrinum tigrinum (SE): Known in Burlington and Ocean Counties, the salamander may occur on the installation. It is found in various habitats that have a nearby water source suitable for breeding.

Pine barrens tree frog, Hyla andersonii (3C, SE): Recorded in Burlington and Ocean Counties (last record in 1983), this species may be found in ponds or riparian areas around the installation. After breeding, the frogs inhabit woodlands bordering ponds and streams.

Mud salamander, Pseudotriton montanus (ST): This species may occur in Burlington and Ocean Counties in muddy springs and slow floodplain streams. Its occurrence on the installation is possible. 
Fish

Brook trout, Salvelinus fontinalis (ST): This species may be found in waters around the installation.

\section{INVERTEBRATES}

Barren's bluet damselfly, Enallagma recurvatum (C2): This species was found in the area in 1987.

Daecke's pyralid moth, Crambus daeckeellus (C2): Endemic to New Jersey pinelands. Recorded from pitch pine lowlands of Ocean County.

Buchholzi's dart moth, Agrotis buchholzi (C2): Endemic to New Jersey pinelands. Fairly common in Ocean and Burlington Counties.

Lemmer's pinnion moth, Lithophane lemmeri (C2): Found in white-cedar swamps of New Jersey pinelands.

\section{Endangered Species Summary}

No known federally listed species occur on Fort Dix, although the piping plover, and the peregrine falcon may occur as rare migrants or transients. The Barren's bluet damselfly is a category species recently found in the area. The grasshopper sparrow is a nesting species recently found within the area, and the loggerhead shrike may nest around Fort Dix as well. The brook trout, wood and bog turtles may be found in watershed areas. Amphibians that may be found in these areas include the pine barrens tree frog, and the mud and tiger salamanders. Several bird species may occur as transients on the installation. These include the state listed least tern, Cooper's hawk, red-shouldered hawk, northern goshawk, and northern harrier. Various shore and marsh birds may also be found. Other species include the short-eared and barred owls as well as the red-headed woodpecker. Five reptile species may also be found on Fort Dix. 
Main Counties: Jefferson, Lewis

Edge County: St. Lawrence

Surrounding Counties: Herkimer, Oneida, Oswego

\section{VERTEBRATES}

\section{Birds}

Golden eagle, Aquila chrysaetos (SE): A rare to uncommon migrant, the occurrence of this species on the installation is possible.

Red-shouldered hawk, Buteo lineatus (ST): This hawk is a common to locally abundant migrant particularly along Lake Ontario. Its breeding range also includes the area around the installation.

Northern harrier, Circus cyaneus (ST): A common to very abundant migrant, especially in the spring along Lake Ontario, this species may be seen on the installation. It may also breed in the area.

American peregrine falcon, Falco peregrinus anatum (FE, SE): This species is a rare migrant through the area, although reintroductions have improved the likelihood that a falcon may be encountered.

Arctic peregrine falcon, Falco peregrinus tundrius (FT, SE): This species is a rare migrant throughout the area.

Northern bald eagle, Haliaeetus leucocephalus alascanus (FE, SE): Known to breed in Jefferson and St. Lawrence Counties, this species may be seen as a transient or migrant on the installation.

Osprey, Pandion haliaetus (ST): A fairly common to common migrant along Lake Ontario, the osprey may be seen around riparian areas on the installation.

Common tern, Sterna hirundo (ST): A locally abundant breeder in Jefferson County, the terns may be seen around riparian areas of the installation as they migrate.

\section{Mammals}

Mountain lion, Felis concolor cougari (FE, SE): Although thought to be extinct, the cougar was historically found in this area.

Indiana bat, Myotis sodalis (FE, SE): The bat is known to occur in Jefferson County and may occur in Lewis and the surrounding counties. Its occurrence while foraging or migrating in riparian areas of the installation is possible. 


\section{Endangered Species Summary}

Locally abundant breeding birds in the area include the bald eagle and the common tern. The golden eagle, red-shouldered hawk, northern harrier, peregrine falcon, and osprey may migrate along areas of the installation. The Indiana bat may be seen foraging or migrating on areas of the installation. 


\section{CAMP EDWARDS NGB 14,200 Acres Massachusetts}

Main County: Barnstable

Surrounding Counties: Dukes, Plymouth, Nantucket

\section{VERTEBRATES}

Birds

Henslow's sparrow, Ammodramus henslowii (SE): This sparrow has been recorded in widely scattered areas throughout the state. It has been found in open fields with a dense growth of grass, weeds, or clover, although wet meadows may be its preferred habitat.

Short-eared owl, Asio flammeus (SE): This species resides in large, undeveloped expanses of coastal sandplain grassland and maritime heathlands. Breeding pairs are found in Barnstable County.

Upland sandpiper, Bartramia longicauda (SE): This bird has been recorded on the installation. The sandpiper is found in large expanses of grassy fields, particularly in mown grass next to airstrips.

Piping plover, Charadrius melodus (FT): Over 20 percent of the Atlantic coast population of this species is found in Massachusetts. It nests in Sandy Neck which is less than $16 \mathrm{~km}$ east of the installation. This bird also is known from Dukes and Plymouth Counties.

Northem harrier, Circus cyaneus (ST): This bird is known to winter regularly on Cape Cod, recent records verified since 1978 have indicated nesting on the Elizabeth Islands in Dukes County. Its occurrence on the installation is likely.

American peregrine falcon, Falco peregrinus anatum (FE, SE): The peregrine migrates along the coast, and may be seen around the installation. A breeding population of this species recently has been reintroduced in the area.

Arctic peregrine falcon, Falco peregrinus tundrius (FT, SE): This species migrates along the coast, and may be seen on the installation.

Northem bald eagle, Haliaeetus leucocephalus alascanus (FE, SE): The bald eagle is known from Barnstable and surrounding counties. It may be seen foraging on riparian or lake areas near the installation.

Migrant loggerhead shrike, Lanius ludovicianus migrans (C2): Historically regarded as a regular late summer migrant to the coast, its occurrence on the installation is possible.

Northem parula, Parula americana (ST): Known to breed in eastem Massachusetts and Cape Cod, this warbler usually inhabits wet woodlands, river margins, and pond shores. Its occurrence on the installation is possible.

Pied-billed grebe, Podilymbus podiceps podiceps (ST): Historically considered a local summer resident, an uncommon spring transient, and a common fall transient, the grebe may be seen in marsh or pond areas around the installation. 
King rail, Rallus elegans (ST): This bird may breed and winter on the installation. The rail winters in saltwater marshes. In Massachusetts, it breeds locally where there are large freshwater and brackish marshes dominated by cattails and other emergent vegetation.

Roseate tern, Sterna dougallii (FE, SE): Approximately 50 to 80 percent of the Northeastem population of this tern has been concentrated around Cape Cod. Its occurrence on the installation while foraging or as a migrant is possible.

\section{Mammals}

Eastern small-footed bat, Myotis sublatus leibii (C2): The installation is within the bat's range. These bats will roost in buildings, and they may be seen foraging or migrating in areas around the installation.

New England cottontail, Sylvilagus transitionalis (C2): The cottontail has been recorded in Bamstable and Dukes Counties. They may be found in a variety of habitats including beach, salt marsh, oak forest with a heavy understory, and open upland fields with little cover.

\section{Amphibians}

Marbled salamander, Ambystoma opacum (ST): Found in low areas around ponds, swamps, and quiet streams during the breeding season. Its range includes areas around the installation.

Eastern spadefoot toad, Scaphiopus holbrokii (ST): Recorded in Barnstable County, the toad requires sandy soils and temporary pools for breeding. Its occurrence on the installation is possible.

Fish

Shortnose sturgeon, Acipenser brevirostrum (FE, SE): Found in coastal waters, installation activities may affect this species.

American brook lamprey, Lampetra appendix (ST): Found in coastal waters, installation activities may affect this species.

\section{INVERTEBRATES}

\section{Others}

Gerhard's underwing moth, Catocala herodias gerhardi (ST): This moth has been recorded on the installation. It usually inhabits oak-pine barrens. 


\section{Endangered Species Summary}

No federally listed species are known to occur on the installation, although the piping plover, roseate tern, and bald eagle are known to breed nearby and may be seen as transients or while foraging on the installation. Peregrine falcons, as well as the loggerhead shrike and eastern small-footed bat, may migrate through the area. The New England cottontail may also be found in the area. The upland sandpiper and Gerhard's underwing moth are state listed species known to occur on the installation. Several state listed birds nest along Cape Cod and are likely to be seen in the area. The marbled salamander and eastern spadefoot toad may be seen in pond or stream areas. Two fish species found in coastal water may be affected by installation activities. 
Main County: Newport News

Surrounding Counties: James City, Hampton, York

\section{VERTEBRATES}

\section{Birds}

Piping plover, Charadrius melodus (FT, ST): Although these birds breed on the Barrier Islands and rarely west of the Chesapeake Bay, they may be seen as transients on the installation.

Wilson's plover, Charadrius wilsoni (SE): Nests on Northhampton County along the Atlantic coast. May be seen as transients on the installation.

Northern harrier, Circus cyaneus (RSE): Historically recorded as an uncommon migrant, this species may be seen on the installation.

Sedge wren, Cistothorus platensis (RSE): An uncommon to common transient and winter resident along the Atlantic coast, the wren may be seen on the installation.

American peregrine falcon, Falco peregrinus anatum (FE, SE): This falcon has been known to nest on retired ships near Fort Eustis. It migrates along the coast and may be seen on the installation.

Arctic peregrine falcon, Falco peregrinus tundrius (FT, SE): Migrates along the coast and may be seen on the installation.

Bald eagle, Haliaeetus leucocephalus (FE, SE): Historically, at least four pairs of eagles have been known to nest on the installation. Eagles are known to nest within the James River watershed, including the Hog Island Refuge near Fort Eustis.

Yellow-crowned night heron, Nycticorax violaceus (RST): An uncommon summer resident of the Coastal plain, but rare in winter, this species may be seen on the installation.

Eastem least tern, Sterna antillarum antillarum (RST): Nests along the Atlantic coast, and feeds in the Chesapeake Bay Estuary. Former colonies were known from Cape Henry. Occurrence of this species on the installation is likely.

Gull-billed tem, Sterna nilotica (RST): Although this term nests mainly on barrier islands along the Atlantic coast, it may be see as a transient on the installation.

Bachman's warbler, Vermivora bachmanii (FE, SE): Considered the rarest warbler in North America, this bird was historically reported in Virginia. It may have occurred only as a migrant. 


\section{Reptiles}

Atlantic loggerhead turtle, Caretta caretta caretta (FT, ST): Immature loggerheads forage in Chesapeake Bay. The occurrence of the loggerheads in waters around the installation is possible.

Canebrake rattlesnake, Crotalus horridus (atricaudatus) (RSE): Known from Newport News County, the snake may be found on the installation.

\section{Endangered Species Summary}

The bald eagle and peregrine falcon are two federally listed species known to occur on the installation. The piping plover may be seen as a transient. The Atlantic loggerhead turtle may be found in waters around the installation. Although the Bachman's warbler was historically recorded in the area, it may be extinct. State listed birds which may be found on the installation include Wilson's plover, northern harrier, sedge wren, yellow-crowned night heron, least tern, and the gull-billed tern. The canebrake rattlesnake may also occur in the area. 


\section{FORT GEORGE MEADE FORSCOM 13,728 Acres Maryland}

Main County: Anne Arundel County

Edge County: Prince Georges

Surrounding Counties: Baltimore, Howard, Calvert; Across bay: Kent, Queen Annes, Talbot

\section{VERTEBRATES}

\section{Birds}

Bachman's sparrow, Aimophila aestivalis (C2): This bird was historically collected in various areas of Prince Georges County, including College Park. These areas are within a 8- to 16- km radius of the installation.

Kirtland's warbler, Dendroica kirtlandii (FE): An occasional migrant throughout the state, this warbler may be seen on the installation.

American peregrine falcon, Falco peregrinus anatum (FE, SE): Found as a migrant throughout the state, this species may be seen on the installation.

Arctic peregrine falcon, Falco peregrinus tundrius (FT, SE): This falcon may be seen as a migrant on the installation. Although the falcon usually migrates along the coast, it may be seen throughout the state.

Bald eagle, Haliaeetus leucocephalus (FE, SE): The bald eagle is known to occur in Anne Arundel, Baltimore, and Prince Georges Counties. Because of the concentration of eagles around the Chesapeake Bay, these birds may be seen as migrants or transients on the installation. Fort George Meade now has an active bald eagle nest within its boundaries.

Migrant loggerhead shrike, Lanius ludovicianus migrans (C2, SE): An uncommon breeding and wintering species in the area, this bird may be seen on the installation.

\section{Mammals}

Southem pygmy shrew, Microsorex hoyi winnemana (C2): The shrew was historically recorded as rare, but may occur in all sections of Maryland. One was collected at Berwyn, Prince Georges County. This is within $24 \mathrm{~km}$ of the installation.

Eastern small-footed bat, Myotis subulatus leibii (C2): This bat may be seen anywhere in the state during migration. Its occurrence on the installation is possible.

\section{Endangered Species Summary}

No listed species are known on Fort Meade, but several may occur. The Kirtland's warbler, peregrine falcon, and bald eagle may be seen as migrants. The loggerhead. shrike and Bachman's sparrow may migrate through areas of the installation as well. The southem pygmy shrew, a rare species in Maryland, and the eastern small-footed bat may also be found on or around the installation. 
FORT GORDON TRADOC 56,662 Acres Georgia

Main County: Richmond

Edge Counties: Columbia, McDuffie, Jefferson

Surrounding Counties: Warren, Glascock, Burke, GA: Edgefield, Aiken, SC

\section{VERTEBRATES}

Birds

American ivory-billed woodpecker, Campephilus principalis principalis (FE, SE): This bird was once found through coastal and southern Georgia, and the installation is within its historic range.

American peregrine falcon, Falco peregrinus anatum (FT, SE): This falcon is a migrant throughout Georgia and was once recorded in Richmond County. Its occurrence on the installation is possible.

Arctic peregrine falcon, Falco peregrinus tundrius (FT): This falcon is a migrant throughout Georgia and its occurrence on the installation is possible.

Southern Bald eagle, Haliaeetus leucocephalus leucocephalus (FE, SE): A transitory species in Richmond County, it is also know to occur in Columbia County.

Wood stork, Mycteria americana (FE): Storks are known to occur in Richmond County, Georgia and Aiken County, South Carolina, and could be found in Burke County, Georgia. The birds may travel up $128 \mathrm{~km}$ from nesting and feeding areas. Falling water levels with high concentrations of fish represent ideal foraging conditions. This bird may be found within or around the installation if such conditions exist.

Red-cockaded woodpecker, Picoides borealis (FE, SE): Four active nesting colonies are known on the installation.

Appalachian Bewick's wren, Thryomanes bewickii altus (C1): This species has been recorded as a common summer resident in the mountain areas of Georgia. Nests were recorded from the Augusta area. Occurrence of this species on the installation is possible.

\section{Reptiles}

American alligator, Alligator mississipiensis (FTSA): Alligators occur throughout the state and may be found on the installation in swamps or freshwater areas.

Eastern indigo snake, Drymarchon courai couperi (FT, ST): The installation is within its historical range. Although habitat is available, this snake has not been observed on the installation.

Gopher tortoise, Gopherus polyphemus (C2): The installation is within its historic range. Although habitat is available, the tortoise has not been found within the installation: 


\section{Mammals}

Red wolf, Canus rufus gregoryi (FE): Although this species is extirpated in Georgia, the installation is within its historic range.

Florida panther, Felis concolor coryi (FE): Although a very rare transient in Georgia, this species once was found throughout the state. Wild populations still exist, making the panther's occurrence on the installation possible, but unlikely.

Eastern cougar, Felis concolor cougari (FE, SE): Although a very rare transient in Georgia, this species once was found throughout the state. Wild populations still exist, making the panther's occurrence on the installation possible, but unlikely.

Indiana bat, Myotis sodalis (FE, SE): Although hibernacula probably do not occur near the installation, these bats may be found individually while foraging or migrating.

\section{Endangered Species Summary}

Red-cockaded woodpeckers are the only federally listed species known on the installation. Habitat is available for the eastern indigo snake and the gopher tortoise, but these species have not been found on the installation. The bald eagle, wood stork, and Appalachian Bewick's wren may be seen as transients. The Indiana bat and American alligator may also be seen on the installation. Peregrine falcons may occur during migration. 
Main Counties: Crawford, Kalkaska

Surrounding Counties: Antrim, Grand Traverse, Missaukee, Oscoda, Otsego, Roscommon, Montmorency

\section{VERTEBRATES}

\section{Birds}

Short-eared owl, Asio flammeus (SE): An uncommon transient and an irregular local summer resident, occurrence of this bird on the installation is possible.

Red-shouldered hawk, Buteo lineatus (ST): Recorded in Grand Traverse and Otsego Counties, this hawk may be found on the installation.

Kirtland's warbler, Dendroica kirtlandii (FE, SE): The warbler is known to breed in areas of the installation where suitable jack pine stands and sandy soil conditions are found. About 30 percent of the state's warbler population is found within the post (i.e., 64 singing males).

Merlin, Falco columbarius (ST): The merlin may occur as an uncommon transient on the installation.

American peregrine falcon, Falco peregrinus anatum (FE, SE): The falcon may occur as an uncommon transient on the installation.

Arctic peregrine falcon, Falco peregrinus tundrius (FT, SE): The falcon may occur as an uncommon transient on the installation.

Common loon, Gavia immer (ST): A common transient and uncommon summer nesting resident in northern Michigan, this species is found in the main and surrounding counties. Its nesting or feeding on the installation is possible.

Northem bald eagle, Haliaeetus leucocephalus alascanus (FE, ST): The eagle is recorded as breeding and wintering in Crawford and Kalkaska Counties. There are several active eagle nesting areas in and around the post. Two sites occur in Kalkaska County just north of the post's leased lands. One nesting area in Crawford County lies partly within the post, while one of two nesting areas in Otsego County is on post. All have been active between 1984 and 1989.

Migrant loggerhead shrike, Lanius ludovicianus migrans (C2, SE): A transient and summer resident in the area, the shrike has been recorded in Grand Traverse and Missaukee Counties. Its occurrence on the installation is possible, but unlikely.

Osprey, Pandion haliaetus (ST): A transient and summer resident, there are known nesting sites in Houghton Lake (Roscommon County). The osprey is also known in Grand Traverse and Kalkaska Counties, and may be found on the installation. 
King rail, Rallus elegans (SE): An uncommon transient and summer resident, the rail may be found on the installation.

\section{Fish}

Cisco/Lake herring, Coregonus artedii (ST): This fish may be found in waters around the installation.

\section{INVERTEBRATES}

Deep water pond snail, Stagnicola contracta (ST): There is a recorded occurrence in Higgin's Lake in nearby Roscommon County. Although it may have a widespread occurrence, little is known about the species except that it is found in 9 to 12 meters of water.

\section{Endangered Species Summary}

The Kirtland's warbler and the bald eagle are the only known federally listed species on the installation. Peregrine falcons may occur as rare transients. State endangered birds that may be found on the installation include red-shouldered hawk, loggerhead shrike, and king rail. State threatened species include the common loon and osprey. The short-eared owl and merlin may be uncommon transients. Cisco may also be found in waters around the installation. 
INDIANA AAP

AMC

7,300 Acres

Indiana

Main County: Clark

Surrounding Counties: Floyd, Jefferson, Scott, Washington

\section{VERTEBRATES}

\section{Birds}

American bittern, Botaurus lentiginosus (SE): A fairly common regular migrant, there is a historical record of this bird nesting in the state. Its occurrence on the installation in marshland areas is possible.

Great egret, Casmerodius albus (SE): A species that declined mainly because of overhunting, the egret is a rare spring migrant and uncommon fall migrant most often seen in its post-breeding wandering period, August to September. Its occurrence on the installation in marsh areas is possible.

Northem harrier, Cirus cyaneus (SE): An uncommon migrant and rare permanent resident, this bird may be found on the installation.

American peregrine falcon, Falco peregrinus anatum (FT, SE): A very rare to casual migrant and winter resident, the falcon was recorded in Jeffersonville Falls Ohio, in 1985 (about $8 \mathrm{~km}$ from the installation). Its occurrence as a migrant on the installation is possible.

Arctic peregrine falcon, Falco peregrinus tundrius (FT, SE): A very rare to casual migrant, the occurrence of this subspecies on the installation is possible.

Northern bald eagle, Haliaeetus leucocephalus alascanus (FE, SE): Recorded in Clark County in November, 1981, the eagle may occur on the river along the installation. It is most commonly seen as a migrant.

Migrant loggerhead shrike, Lanius ludovicianus migrans (C2, SE): A rare migrant and very rare summer resident, historical breeding localities have been recorded in Jefferson County. The shrike's occurrence on the installation is possible.

Black-crowned night heron, Nycticorax nycticorax (SE): Historically recorded as nesting in Clark County, this bird is now considered a rare migrant and casual winter resident. It may be found in marsh areas of the installation.

Yellow-crowned night heron, Nycticorax violaceus (SE): A casual to rare migrant and summer resident, this bird may be found in marsh areas of the installation.

Osprey, Pandion haliaetus (SE): A rare to uncommon migrant throughout Indiana, the osprey may be seen on waters around the installation.

Interior least tern, Sterna antillarium antholassos (FE, SE): Found along the Ohio River, this species may be seen on the installation. 
Common barn owl, Tyto alba (SE): A permanent resident in various areas of the state, the barn owl may be found on or near the installation in man-made structures such as barns or storage buildings.

\section{Reptiles}

Kirtland's snake, Clonophis kirtlandii (C2, ST): This snake is found within a 3-km radius of the installation. Historically, this species was also recorded in Clark, Floyd, and Washington Counties.

\section{Mammals}

Bobcat, Felis rufus (SE): The bobcat is found within a 3-km radius of the installation.

Gray bat, Myotis grisecens (FE, SE): A breeding colony was discovered in Clark County in 1982. Postbreeding wanderers may be found on wooded riparian areas of the installation.

Indiana bat, Myotis sodalis (FE, SE): Hibernating caves are located in Washington County, making occurrence of this species on the installation possible (most likely in the fall).

Evening bat, Nycticeius humeralis (SE): A hibernating cave located in Clark County makes the occurrence of this species on the installation possible. Records from Scott and Washington Counties support the claim.

Badger, Taxidea taxus (ST): Historically this species was collected in the state. It may be found on the installation.

\section{Amphibians}

Hellbender, Cryptobranchus a. alleganiensis (C2, SE): The hellbender is found in waters on the installation.

\section{Fish}

Blue sucker, Cycleptus elongatus (C2): Historically found in the Ohio River, this fish may be found in waters around the installation.

\section{INVERTEBRATES}

\section{Mollusks}

Tubercled blossom, Epioblasma torulosa torulosa (FE, SE): Although this species is probably extinct, it was historically found in the Ohio River. 
Long-solid, Fusconia subrotunda (SE): This species was historically found in the Wabash River, and may possibly be found in waters around the installation.

Pink mucket, Lampsilis abrupta (orbiculata) orbiculata (FE, SE): This species was historically collected from the Ohio River and may be found in gravel shoals around the installation.

Orange-footed pearly mussel, Plethobasus cooperianus (FE, SE): This species was historically found throughout the Ohio River. This mussel may be extirpated from the area.

Rough pigtoe, Pleurobema plenum (FE, SE): This species was historically found throughout the Ohio River. This mussel may be extirpated from the area.

Rough rabbit's foot, Quadrula cylindrica strigillata (C2): This species was historically found in the Ohio River drainage, but may be extirpated from the area.

\section{Endangered Species Summary}

No federal species are known to occur on the installation, although the gray and Indiana bats may be seen foraging or migrating. Peregrine falcons and the bald eagle may be observed during migration. The eastern hellbender is known to occur on the installation. The bobcat and Kirtland's water snake are known to occur within a 3-km radius of the installation. Several state listed wading birds, as well as the northern harrier, common bam owl, osprey, and loggerhead shrike may be found within the area. Occurrence of the evening bat, badger, and blue sucker is also possible. The status of the several mollusk species listed is uncertain. 


\section{FORT INDIANTOWN GAP FORSCOM 18,353 Acres Pennsylvania}

Main Counties: Dauphin, Lebanon

Surrounding Counties: Berks, Lancaster, Schuylkill

\section{VERTEBRATES}

Birds

Grasshopper sparrow, Ammodramus savannarum pratensis (ST). This species has been reported in Dauphin and Lebanon Counties. The sparrow is found in grassy fields.

Upland sandpiper, Bartramia longicauda (ST): This species has been reported in Dauphin and Lebanon Counties. The sandpiper is usually found in fallow fields, pastures, or grassy areas.

Arctic peregrine falcon, Falco peregrinus tundrius (FT): The falcon may be seen as a migrant throughout the state of Pennsylvania.

\section{Reptiles}

Bog turtle, Clemmys muhlenbergi (C2, SE): The bog turtle ranges within the area of the installation. Its occurrence in aquatic areas on the installation is likely.

\section{Mammals}

Indiana bat, Myotis sodalis (FE, SE): The bat is listed as possibly occurring in the main and surrounding counties of the installation. The bats have not been recorded in Pennsylvania in the winter months, but they may be seen migrating in the area.

\section{INVERTEBRATES}

Sugar maple longhorn beetle, Dryobius sexnotatus (C2, ST): This species has been recorded in Dauphin County. It may be dependent on climax eastern hardwood forest habitat.

Tawny crescent, Phyciodes batesii (C2, ST): Recorded in Dauphin County, this insect is usually found in dry open hillside fields. The blue wood aster, Aster undulatus, is the primary habitat for this species.

Invertebrate species: There is a highly sensitive invertebrate species which has been found on the installation (Contact the Pennsylvania Heritage Program director for more information). 


\section{Endangered Species Summary}

No federal or state listed animal species are known to occur on the installation. The peregrine falcon and Indiana bat may be seen as migrants around the installation. Candidate insects that have been recorded in the area include the sugar maple longhom beetle and the tawny crescent. Another sensitive invertebrate species has been found on the installation. The grasshopper sparrow and upland sandpiper have been recorded within the main counties of the installation. The bog turtle may be found in waters around the installation. 
FORT JACKSON

TRADOC $\quad 52,596$ Acres

South Carolina

Main Counties: Kershaw, Richland, Sumter

Surrounding Counties: Calhoun, Chester, Chesterfield, Clarendon, Fairfield, Lancaster, Lee, Lexington, Newberry

\section{VERTEBRATES}

\section{Birds}

Golden eagle, Aquila chrysaetos (SE): This eagle is a rare fall transient and winter visitor throughout the Carolinas. Its occurrence on the installation is possible.

American ivory-billed woodpecker, Campephilus principalis principalis(FE, SE): Although this species was found throughout the southeast, its present distribution is unknown and it is thought to be extinct.

Kirtland's warbler, Dendroica kirtlandii (FE, SE): This warbler has been recorded as a fall migrant in Richland County, making its occurrence on the installation possible.

American peregrine falcon, Falco peregrinus anatum (FE, SE): An uncommon fall transient and rare winter resident on the coast, occurrence of this species on the installation is possible.

Arctic peregrine falcon, Falco peregrinus tundrius (FE, SE): An uncommon fall transient and rare winter resident on the coast, occurrence of this species on the installation is possible.

Southem bald eagle, Haliaeetus leucocephalus leucocephalus (FE, SE): Known to occur in Chesterfield and Clarendon counties. Eagles may occur as transient on waters around the installation.

Wood stork, Mycteria americana (FE, SE): A locally common summer resident and uncommon winter resident of swamps, marshes and mudflats, storks feed in areas with receding water levels and high concentrations of fish.

Red-cockaded woodpecker, Picoides borealis (FE, SE): Colonies are present on the eastern end of the installation.

Appalachian Bewick's wren, Thryomanes bewickii altus (C1): This bird is a rare breeding species and probably a rare transient within the area.

Bachman's warbler, Vermivora bachmainii (FE, SE): Present distribution of this species is unknown and records are rare, but historically this species was found throughout the southeast.

\section{Reptiles}

American alligator, Alligator mississippiensis (FTSA): Richland and Kershaw Counties are on the edge of the alligator's range. The alligator inhabits swampy areas, and occurrence on the installation is possible. 


\section{Mammals}

Red wolf, Canis rufus gregoryi (FE) Although this species is extirpated in South Carolina, the installation is within its historic range. Captive bred wolves have been released at Alligator River National Wildlife Refuge in North Carolina.

Eastern cougar, Felis concolor cougari (FE, SE): Possible occurrences in Chesterfield County. Although this species is probably extirpated in South Carolina, the installation is within its historic range. Wild populations may still exist, making the occurrence of this species possible.

Florida panther, Felis concolor coryi (FE): Although this species is probably extirpated in South Carolina, the installation is within its historic range. Wild populations may still exist, making the occurrence of this species possible.

Rafinesque's big-eared bat, Plecotus rafinesquii (C2): Found in dilapidated buildings near water or in hollow trees behind loose bark, this species ranges within the area of the installation.

\section{Endangered Species Summary}

Red-cockaded woodpeckers are the only federally listed species known to occur on the installation. The Kirtland's warbler, peregrine falcons, bald eagle, or wood stork may be seen as transients. Other species of concern with a reasonable liklihood of occurrence include the American alligator and Rafinesque's big-eared bat. 


\section{JEFFERSON PROVING GROUND AMC $\quad 55,264$ Acres Indiana}

Main Counties: Jefferson, Jennings, Ripley

Surrounding Counties: Bartholomew, Dearborn, Decatur, Franklin, Jackson

\section{VERTEBRATES}

Birds

Henslow's sparrow, Ammodramous henslowii (ST): An uncommon summer resident and migrant, locally common, this sparrow nested in Jefferson County in 1980. Its occurrence on the installation is possible.

American bittern, Botaurus lentiginosus (SE): A fairly common regular migrant, the bittern may be seen on marshland areas of the installation.

Great egret, Casmerodius albus (SE): A species that declined mainly because of overhunting, the egret is a rare spring migrant and uncommon fall migrant most often seen in its post-breeding wandering period, August to September. Recent nesting records (1984) are from Jennings County. Its occurrence on the installation in marsh areas is possible.

Northern harrier, Circus cyaneus (SE): An uncommon migrant and rare permanent resident, this bird may be found on the installation.

Peregrine falcon, Falco peregrinus (FE, SE): A very rare to casual migrant and winter resident, the falcon was seen in Clifty Falls State Park in 1978. Its occurrence on the installation is possible.

Northern bald eagle, Haliaeetus leucocephalus alascanus (FE, SE): The eagle may be seen wintering around open water areas of the installation.

Migrant loggerhead shrike, Lanius ludovicianus migrans (C2, SE): A rare migrant and very rare summer resident, its occurrence on the installation is possible. Historical breeding localities have been recorded in Jefferson County.

Yellow-crowned night heron, Nycticorax violaceus (SE): A casual to rare migrant and summer resident, this bird may be found in marsh areas of the installation.

King rail, Rallus elegans (SE): An uncommon migrant and summer resident, historical records indicate nesting in Ripley County. Its occurrence on the installation is possible.

Common barn owl, Tyto alba (SE): A permanent resident in various areas of the state, the barn owl may be found on or near the installation in man-made structures such as barns or storage buildings. Nested in Jefferson County in 1985. 


\section{Reptiles}

Kirtland's snake, Clonophis kirtlandii (C2, ST): Historically recorded in Jennings and Jefferson Counties, this species is known to occur on the installation.

\section{Mammals}

Bobcat, Felis rufus (SE): Historically recorded in Jennings County, the occurrence of this species on the installation is possible.

Gray bat, Myotis grisescens (FE, SE): A rare post-breeding wanderer in Indiana, this species was recorded in Jennings County. Its occurrence on the installation is possible.

Indiana bat, Myotis sodalis (FE, SE): Generally seen in the fall, this bat has been recorded in Jennings and Ripley Counties. Its occurrence migrating or foraging in riparian areas of the installation is possible.

Evening bat, $N y$ cticeius humeralis (SE): An uncommon summer resident, historically the bat was recorded in Ripley and Jackson Counties. Its occurrence on the installation is possible.

\section{Fish}

Eastern sand darter, Ammocrypta pellucida (C2): This species has been collected in Graham Fork, Jennings County. It may be found in waters around the installation.

\section{Endangered Species Summary}

No federally listed species are known to occur on the installation, although Indiana and gray bats may be seen foraging or migrating. The Kirtland's water snake is the only state listed species known to occur on the installation. Several species of state listed wetland birds may occur in riparian areas. The northem harrier, common barn owl, Henslow's sparrow, and loggerhead shrike may also occur on the grounds. Occurrence of the bobcat and evening bat is possible. The eastern sand darter may be found in waters around the installation. 
JOLIET AAP AMC 23,500 Acres Illinois

Main County: Will

Surrounding Counties: Cook, DuPage, Grundy, Kankakee, Kendall, Kane, IL; Lake, IN

\section{VERTEBRATES}

Birds

Cooper's hawk, Accipiter cooperi (SE): Recent nesting records are in Will County, and its occurrence on the installation is possible. An uncommon migrant and winter resident, the hawk is also found in Cook, DuPage, and Kane Counties.

Sharp-shinned hawk, Accipiter striatus (SE): A common migrant, uncommon winter resident and, very rare resident, this hawk was recorded in Will County in June, 1982. Its occurrence on the installation is possible.

Henslow's sparrow, Ammodramus henslowii (ST): This sparrow may be found on the installation. An occasional migrant and very local summer resident, the state's highest count of this bird for spring migration was made in Goose Lake in 1985 (Goose Lake is also a breeding area). There is a strong possibility that it breeds on this site.

Short-eared owl, Asio flammeus (SE): An uncommon migrant and winter resident, and rare summer resident, this owl has been recorded as nesting in Goose Lake Prairie, making its occurrence on the installation possible. The owl has also been recorded in Cook, DuPage, and Grundy Counties.

Upland sandpiper, Bartramia longicauda (SE): Seventy adults and one nest were recorded on the installation in 1990.

American bittem, Botaurus lentiginosus (SE): This species is an uncommon migrant and rare summer and winter resident in Will County. It is also listed as occurring in Cook, Grundy, and Kane Counties. Since breeding has been recorded in Goose Lake Prairie, and along large marshes of major rivers, its occurrence on the installation is probable.

Red-shouldered hawk, Buteo lineatus (SE): An uncommon migrant and summer resident, this hawk is listed as occurring in Will and Cook Counties. Its occurrence on the installation is possible.

Swainson's hawk, Buteo swainsoni (3C, SE): A rare migrant and local summer resident in northern Illinois, this hawk is listed as occurring in Cook and Kane Counties. Its occurrence on the installation is possible, most likely as a migrant.

Great egret, Casmerodius albus (SE): The highest counts for the state in 1985 were 148 in Will County. A common migrant and summer resident along major rivers of the state, occurrence on the installation is likely. 
Veery, Catharus fuscescens (ST): A common spring migrant and an occasional summer resident in northern parts of central Illinois, the veery is listed as occurring in Will, Cook, and Kane Counties. Its occurrence on the installation is likely.

Brown creeper, Certhia americana (ST): This bird is listed as occurring in Will County. Recorded as nesting along the Kankakee River, its occurrence on the installation is possible.

Black tern, Chlidonias niger (SE): This species is a common migrant and common summer resident in northern Illinois and a rare summer resident in central Illinois. The tern is listed as occurring in Will, Cook, DuPage, Grundy, and Kane Counties. Its occurrence on the installation is possible.

Northern harrier, Circus cyaneus (SE): A nest was recorded on the installation in 1988. Adults were also observed in 1990.

Little blue heron, Egretta caerulea (SE): An uncommon migrant and a postbreeding wanderer throughout the state, this heron has been recorded in Will, Cook, and DuPage Counties. Its occurrence on the installation as a post-breeding wanderer is possible.

Snowy egret, Egretta thula (SE): A rare migrant, post-breeding wanderer, and local summer resident, this egret is listed as occurring in Will and Cook Counties. Its occurrence on the installation is most likely as a post-breeding wanderer.

American peregrine falcon, Falco peregrinus anatum (FE, SE): An uncommon migrant and rare winter resident, peregrines are being reintroduced to the state. Their occurrence on the installation is possible.

Arctic peregrine falcon, Falco peregrinus tundrius (FT, SE): An uncommon migrant and rare winter resident, the occurrence of these peregrines on the installation is possible.

Common moorhen, Gallinula chloropus (ST): An uncommon migrant and locally uncommon summer resident in northern Illinois (decreasing southward), the occurrence of this species in marsh areas of the installation is possible. The moorhen occurs in Will, DuPage, Grundy, and Kane Counties.

Sandhill crane, Grus canadensis (SE): An uncommon migrant and very rare summer resident in northern Illinois, the cranes were recorded wintering in Will County in 1983. Their occurrence on the installation is possible.

Northem bald eagle, Haliaeetus leucocephalus alascanus (FE, SE): The eagle is known to winter along the Illinois and Kankakee Rivers in Will County, and is known to use areas on the installation.

Least bittern, Ixobrychus exilis (SE): An uncommon migrant and summer resident historical records indicate this species occurred in Will County. Occurrence on the installation is possible.

Migrant loggerhead shrike, Lanius ludovicianus migrans (C2, ST): An occasional migrant and summer and winter resident, this bird nested on the installation in 1988, 1989, and 1990.

Black-crowned night heron, Nycticorax nycticorax (SE): High counts for the state for spring migration in Will County were 378 in 1984 . The occurrence of the heron as a nesting species on the installation is likely. This bird is also found in Cook, DuPage, and Grundy Counties. 
Osprey, Pandion haliaetus (SE): Recorded in Will and Cook Counties, the osprey may be seen as an uncommon migrant along river areas of the installation.

Double-crested cormorant, Phalacrocorax auritus (SE): An uncommon migrant along the Illinois River, this bird was recorded in Will and Cook Counties. Its occurrence on the installation is possible.

Pied-billed grebe, Podilymbus podiceps (SE): Reported in Will County in 1986, the grebe is a common migrant and uncommon summer and winter resident. Its occurrence on the installation is possible.

Least tern, Sterna antillarium (FE): A rare migrant and postbreeding wanderer in this area of the state, its rare occurrence on the installation is possible.

Forster's tern, Sterna forsteri (SE): A common migrant and occasional summer resident in northeastem Illinois, this tern was formerly observed on the installation.

Common tern, Sterna hirundo (SE): A common migrant and rare summer resident on Lake Michigan, this bird is a fairly common migrant elsewhere in the state. Its occurrence as a migrant on the installation is possible.

Bewick's wren, Thryomanes bewickii bewickii (ST): An occasional migrant and summer resident in southern Illinois (decreasing northward), this species has been recorded in Cook and Kane Counties. It may be found as a migrant on the installation.

Barn owl, Tyto alba (SE): An occasional permanent resident, this owl was found in a barn in Will County in 1987. Its occurrence roosting in man-made structures on the installation is possible.

Yellow-headed blackbird, Xanthocephalus xanthocephalus (SE): A locally uncommon migrant and summer resident, the blackbird was listed as occurring in Will, Cook, DuPage, and Kane Counties. Its occurrence on the installation is possible.

\section{Reptiles}

Spotted turtle, Clemmys guttata (SE): This turtle is listed as occurring in Will, Cook, DuPage Counties. Illinois is at the far western periphery of its range, and occurrence on the installation is pessibte.

Kirtland's snake, Clonophis kirtlandi (C2): This snake is listed as occurring in Cook County. Its occurrence on the installation is possible.

\section{Mammals}

River otter, Lutra canadensis (ST): This species is listed as occurring in Kane County. Since its range includes the installation, it may occur in riparian areas of the base.

Bobcat, Felis rufus (ST): The installation is within the range of the bobcat, which is listed as occurring in Grundy County. Occurrence of this species is possible. 
Indiana bat, Myotis sodalis (FE, SE): This bat is listed as occurring in Cook County. Statewide in distribution, the bat may be found in riparian areas with mature trees. It forages for insects by flying under tree canopies. Its occurrence on the installation in these areas is possible.

\section{Fish}

River redhorse, Moxostoma carinatum (ST): Common to the Kankakee River, this species may be found in waters around the installation.

Bigeye shiner, Notropis boops (ST): This fish is found in the Illinois River downstream from the installation.

Blacknose shiner, Notropis hererolepis (ST): Historically found in the Kankakee River in Will County, this fish may occur in waters around the installation.

\section{INVERTEBRATES}

\section{Mollusks}

Slippershell mussel, Alasmidonta viridis (SE): This mollusk was collected about $16 \mathrm{~km}$ upstream from the installation is 1985 . Its occurrence in waters around the installation is possible.

Spectaclecase, Cumberlandia monodonta (C2, SE): This mollusk was historically collected in the Kankakee River less than $8 \mathrm{~km}$ from the installation. Its occurrence in waters on or around the installation is possible.

Elephant-ear, Elliptio crassidens (ST): This was collected in the Illinois River less than $24 \mathrm{~km}$ from the installation. Its occurrence in waters on or around the installation is possible.

Snuff box, Epioblasma triquetra (SE): Recorded in the Kankakee River, this species was collected in 1988 less than $8 \mathrm{~km}$ from the installation.

Cracking pearly mussel, Hemistena lata (FE, SE) This species was historically collected from the Illinois River, in waters around the installation.

Higgins eye, Lampsilis higginsi (SE): Historically collected less than $8 \mathrm{~km}$ from the installation on the Kankakee River, this species may be found in waters on or around the installation.

Creek heelsplitter, Lasmigona compressa (ST): This species was historically collected in areas less than $16 \mathrm{~km}$ upstream from the installation. Occurrence is possible.

Sheepnose, Plethobasus cyphyus (ST): This species was collected in the Kankakee River in 1988, less than $8 \mathrm{~km}$ from the installation.

Salamander mussel, Simpsonaias ambigua (C2): This species was historically collected in the Kankakee River. 
Rainbow, Villosa iris (SE): This species was collected in 1985 in the Kankakee River, less than 8 km from the installation.

\section{Endangered Species Summary}

The bald eagle is the only federally endangered species known to occur on the installation. Mature, wooded, riparian areas could harbor the Indiana bat. Peregrine falcons and the least tern may occur as migrants or transients. Several state listed species are known to occur, including the upland sandpiper, northern harrier, and migrant loggerhead shrike. Several state and federally listed mollusks may be found in the Illinois and Kankakee Rivers around the installation. Several other state listed species, including herons, egrets, river otters, and fish may occur in wetland areas of the installation. 
FORT KNOX TRADOC 109,667 Acres Kentucky

Main Counties: Meade, Hardin, Bullitt

Surrounding Counties: Breckinridge, Grayson, Hart, Jefferson, LaRue, Nelson, Spencer, KY; Harrison, IN

\section{VERTEBRATES}

Birds

Spotted sandpiper, Actitis macularia (SE): A common late spring and early fall transient, this bird was recorded as a migrant around Louisville and may also breed in the area.

Bachman's sparrow, Aimophila aestivalis (C2, ST): This bird is listed as occurring in Meade and Hardin Counties as a summer resident and breeding species. Its preferred habitat includes open pastures, thick grass with low trees, open grassy woodlands, and old fields.

Blue-winged teal, Anas discors (SE): A common transient in Kentucky in the late spring and early fall, this species was observed around Louisville. It may also breed in this area.

Upland sandpiper, Bartramia longicauda (SE): Historical records indicate this species was recorded during spring migrations in Louisville. In the fall it was recorded in Shepherdsville and near Elizabethtown. A rare to uncommon transient in Kentucky, it may possibly be seen on the installation around open grassland areas.

American bittern, Botaurus lentiginosus (SE): This species has been recorded in the spring and fall around Louisville. Considered a rare to uncommon transient. Bitterns are most frequently found in cattail marshes, but occasionally they are found in the thick vegetation along ponds, lakes, and streams.

American ivory-billed woodpecker, Campephilus principalis principalis (FE): Although this bird is thought to be extinct, it was once found throughout the southeast U.S. Historical records for Tennessee and Kentucky are sketchy, but the installation is possibly within the bird's historic breeding range.

Great egret, Casmerodius albus (SE): An uncommon transient and nonbreeding visitor in Kentucky, records indicate this bird was a spring migrant in Louisville and Meade County.

Lark sparrow, Chondestes grammacus (SE): In Kentucky this bird is a rare to common summer resident. It was recorded as a spring migrant around Louisville, and possibly bred in Fayette and Bullitt Counties. Although generally considered a grassland bird, it will occupy rocky outcrops or areas with sparse ground cover mixed with rock.

Blackburnian warbler, Dendroica fusca (SE): A fairly common transient in Kentucky. This warbler has been observed around Louisville as a migrant.

Little blue heron, Egretta caerulea (SE): A post-breeding visitor that may be seen around the installation in late summer and into fall. There is a 1985 record for this species in Jefferson County. 
American peregrine falcon, Falco peregrinus anatum (FE, SE): An extremely rare transient and winter visitor. It is possible this species could be seen on the installation.

Arctic peregrine falcon, Falco peregrinus tundrius (FE, SE): An extremely rare transient and winter visitor. This species was recorded in Meade County. It is possible this species could be seen on the installation.

American coot, Fulica americana (SE): In Kentucky, the coot is a common transient, uncommon winter resident, and a very rare summer resident and nesting species. It is found in a wide variety of aquatic habitats, and was recorded as a migrant around Louisville.

Common moorhen, Gallinula chloropus (SE): A rare transient, the moorhen was recorded in the Louisville area as a migrant. Its occurrence on the installation in marshy areas is possible.

Bald eagle, Haliaeetus leucocephalus (FE, SE): Known in the main counties as well as Grayson County, the eagle has been observed occasionally on the installation, but only as a migrant. The birds recorded could be either the southern or northern subspecies (leucocephalus and alascanus).

Least bittern, Ixobrychus exilis (SE): A rare transient and rare summer resident, this species historically was recorded nesting in marshy areas around Louisville. Its occurrence on or around the installation is possible.

Hooded merganser, Lophodytes cucullatus (SE): In Kentucky this bird is a fairly common transient and rare winter resident. It is a rare summer resident in western Kentucky and breeds locally. In winter, it was commonly found from Louisville westward to Kentucky Lake. Occurrence of this species on or around the installation at the Ohio River is possible.

Black-crowned night heron, Nycticorax nycticorax (SE): This heron is an uncommon to fairly common summer resident. Breeding colonies historically were observed in the Louisville area. Herons also were observed wintering in the area. In 1985, this heron was recorded in Jefferson County. These birds are generally found near swamps. Their occurrence around the installation is possible.

Yellow-crowned night heron, Nycticorax violaceus (ST): An uncommon and local transient and summer resident. This species historically was recorded nesting around Louisville. Recently (1985), the heron was recorded nesting in Bullitt County. The herons are usually found in forested areas near swamps or sloughs, and may be seen on the installation.

Osprey, Pandion haliaetus (SE): A common transient and widespread migrant throughout Kentucky, ospreys are found near ponds, lakes, and streams. Their occurrence around the installation in the spring or fall is likely. Historical records indicate this bird nested in the Louisville area, although it has not nested in recent years.

Double-crested cormorant, Phalacrocorax auritus (SE): In Kentucky the cormorant is an uncommon to fairly common transient, rare winter resident, and rare nonbreeding summer visitor. Historical records show this species was seen on the Ohio River. Occurrence in riparian areas on or near the installation is possible. 
Pied-billed grebe, Podilymbus podiceps (SE): A fairly common transient and rare to uncommon winter resident. Historically this species was seen in the Louisville area, where it nested and remained in the area until November. It may be seen in marshy areas on or near the installation at these times.

King rail, Rallus elegans (SE): Rare transient and summer resident, the rail is mainly found in marshy habitats. Historical records indicate this bird nested in the area around Louisville. There is a 1982 nesting record for the rail in Jefferson County.

Piping plover, Charadrius melodus (FT): Recorded as nesting in Jefferson County in 1985, the plover is otherwise a rare transient in Kentucky. Its occurrence on the installation is possible.

Migrant loggerhead shrike, Lanius ludovicianus migrans (C2): The shrike may nest in the area. An uncommon to fairly common resident, the shrike is found in a variety of semi-open and open habitats.

Interior least tern, Sterna antillarum athalassos (FE, SE): This tem may be seen as a transient on the installation. The tem was recorded breeding at the Falls of Ohio in 1967.

Appalachian Bewick's wren, Thryomanes bewickii altus (C1): Rare in spring and summer and very rare in fall and winter. The Bewick's wren may be found on the installation. This wren is found in a variety of habitats with brushy cover.

\section{Reptiles}

Kirtland's snake, Clonophis kirtlandii (SE): Known in Jefferson County, this snake can be found far from water. It usually hides under stones or debris in wet meadows.

Northern copperbelly water snake, Nerodia erythrogaster neglecta $(\mathrm{C} 2)$ : This species may be found in waters around the installation.

\section{Mammals}

Red wolf, Canis rufus gregoryi (FE): Although the remaining red wolves are in captivity or within an experimental population, the installation is within their historic range.

Eastern cougar, Felis concolor cougar (FE, SE): The cougar once ranged throughout the southeast, including the area of the installation. Wild populations of the cougar may still exist, making its occurrence on the installation possible, although unlikely.

Gray bat, Myotis grisescens (FE, SE): The bat is known to occur in caves on the installation.

Indiana bat, Myotis sodalis (FE, SE): Found in caves on Fort Knox, the bat also is known to exist in Breckinridge, and Grayson Counties. Bats probably hibernate in these areas.

Pygmy shrew, Microsores hoyi winnemana (C2): This shrew was recorded in Bullitt County in 1984, and may be seen in the area of the installation. This particular species has been found in various habitats, including bogs, woods, grassy fields, and brushy areas on forest edges. 
Southeastern bat, Myotis austroriparius (C2, SE): These bats forage just above the surface of quiet water. Habitats used for nursery colonies are unknown. Recorded in Hardin County in 1987, it is possible these bats may be seen foraging on the installation.

Eastern small-footed bat, Myotis sublatus leibii, (C2, SE): This bat inhabits old mines and buildings, is found under the bark of trees, and beneath slabs of rocks in quarries. It may be found in areas around the installation.

Eastern woodrat, Neotoma floridana magister (C2): Generally associated with rocky outcrops, the woodrat was recorded in Meade and Hardin Counties in 1984 and 1987. Its occurrence in areas around the installation is possible.

Evening bat, Nycticeius humeralis (ST): An uncommon summer resident, the evening bat prefers buildings or trees over caves for roost sites. It may be seen in areas around the installation.

Rafinesque's big-eared bat, Plecotus rafinesquii (C2, ST): This bat is usually found roosting in unoccupied buildings or other man-made structures. It is possible this bat may be seen in and around the installation.

\section{Amphibians}

Hellbender, Cryptobranchus alleganiensis (C2): Generally distributed statewide, this species was recorded in Meade County. Hellbenders are found in large streams and rivers where large stones provide nesting sites and protection. Their occurrence in waters around the installation is possible.

\section{Fish}

Northern cavefish, Amblyopsis spelaea (C2): Found in Meade and Hardin Counties, this species occurs in caves on Fort Knox.

Eastern sanddarter, Ammocrypta pellucida (C2): Listed in Hardin County, sporadic collections were taken from the Rolling Fork River. Occurrence of this species in installation waters is possible.

Blue sucker, Cycleptus elongatus (C2): Listed in Meade County, a specimen was taken in the Ohio River below Lock and Dam 43. This sucker occurs in the waters around the installation.

\section{INVERTEBRATES}

\section{Mollusks}

Orange-footed pearly mussel, Plethobasus cooperianus (FE, SE): Listed as occurring in Bullitt County, this species was historically found throughout the Ohio River. This mussel may be extirpated from the area. 
Rough pigtoe, Pleurobema plenum (FE, SE): Possibly occurring in Hart County, this species was historically found throughout the Ohio River. This mussel may be extirpated from the area.

Rough rabbit's foot pearly mussel, Quadrula cylindrica strigillata (C2, SE): Listed as occurring in Hardin County, this species historically was found in the Ohio River drainage. This mussel may be extirpated from the area.

Salamander mussel, Simpsonaias ambigua (C2, ST): This species is listed as occurring in Bullitt County.

Ortmann's pearly mussel, Villosa (Micromya) ortmanni (C2, SE): This species is listed as occurring in Hardin County.

Eastem fanshell, Cyprogenia stegaria (ST): Historically collected in the Ohio River drainage, this species may still persist in waters around the installation.

Cracking pearly mussel, Hemistena lata (FE, SE): This species was historically collected in the Ohio River.

Pink mucket pearly mussel, Lampsilis abrupta (FE, SE): This mussel was historically collected in the Ohio River.

Ring pink, Obovaria retusa (FE, SE): This species was historically found throughout the Ohio River.

Fat pocketbook pearly mussel, Potamilus capax (FE, SE): This species was historically collected in the Ohio River and may be found in waters around the installation.

Purple lilliput mussel, Toxoplasma lividus (C2, SE): This species was historically collected in the Ohio River drainage.

Bean villosa, Villosa fabalis (C2, SE): This mussel was historically collected in the Ohio River drainage.

\section{Other}

Louisville crayfish, Orconectes jeffersoni (C2, SE): This species is listed as occurring in Bullitt and Jefferson Counties.

Onyx rocksnail, Leptoxis praerosa (C2): Historically collected in the Ohio River drainage, this species may still persist in the waters around the installation.

\section{Endangered Species Summary}

The Indiana and gray bats are the only species known to occur in caves on the installation. The bald eagle is also known as an annual visitor. Candidate species known to be present include the northern cavefish and blue sucker. State listed bird species that may breed in the area include the spotted sand piper, Bachman's sparrow, blue-winged teal, lark sparrow, least bittern, black-crowned night heron, yellowcrowned night heron, and king rail. The others listed above may be observed as migrants or transients. Other candidate and state listed species that should be looked for include the loggerhead shrike, Berwick's wren, two snake species, several bats, eastern wood rat, hellbender, eastern sand darter, Louisville crayfish, and onyx snail. Surveys are needed to document the status of state and federally listed mussels. 
FORT LEE TRADOC $\quad$ 6,504 Acres $\quad$ Virginia

Main County: Prince George

Surrounding Counties: Charles City, Chesterfield, Dinwiddle, Surry, Sussex

\section{VERTEBRATES}

Birds

Henslow's sparrow, Ammodramous henslowii (RSE): Found in low wetlands covered with brushes and sedges and sometimes in clearings, it historically bred in eastern Virginia.

Northem harrier, Circus cyaneus (RSE): Historically recorded as an uncommon migrant, this species may be seen as a transient on the installation.

American peregrine falcon, Falco peregrinus anatum (FE, SE): A migrant along the coast, the falcon may be seen as a transient on the installation.

Bald eagle, Haliaeetus leucocephalus (FE, SE): There is a nesting record for this species on Fort Lee.

Loggerhead shrike, Lanius ludovicianus ludovicianus (SE): Recorded nesting in Chesterfield County, the shrike may be seen on the installation.

Yellow-crowned night heron, Nycticorax violaceus (RST): An uncommon summer resident of the coastal plain, and rare in winter, this species may be seen on the installation.

Bachman's warbler, Vermivora bachmanii (FE, SE): Considered the rarest warbler in North America, this bird historically was reported in Virginia. It may have occurred only as a migrant.

Fish

Blackbanded sunfish, Enneacanthus chaetodon (SE): Reported from waters on Fort Lee. It occurs in the Blackwater Swamp (a tributary to the Blackwater River).

\section{Endangered Species Summary}

The bald eagle has been recorded as nesting on the installation, and the state listed blackbanded sunfish has been recorded in waters on Fort Lee. Other federally listed species which may be seen as transients include the peregrine falcon and Bachman's warbler. The state listed loggerhead shrike may nest in the area. Other birds which may occur as transients include the Henslow's sparrow and the northern harrier. 
LETTERKENNY AD AMC 19,000 Acres Pennsylvania

Main County: Franklin

Surrounding Counties: Adams, Cumberland, Fulton, Huntington, Juniata, Perry, PA; Washington, MD

\section{VERTEBRATES}

\section{Birds}

Henslow's sparrow, Ammodramus henslowii (ST). This species is known to occur on the installation. It is generally found in open fields and meadows with grass interspersed with weeds or shrubby vegetation, especially in low-lying areas.

Grasshopper sparrow, Ammodramus savannarum (ST): The sparrow is known to occur in large grassy areas of the installation.

Upland sandpiper, Bartramia longicauda (ST): This species has been historically reported in Franklin County. The sandpiper is usually found in fallow fields, pastures, or grassy areas.

Arctic peregrine falcon, Falco peregrinus tundrius (FT): The falcon may be seen as a migrant throughout Pennsylvania.

Bewick's wren, Thryomanes bewickii altus (C1, ST): Historically, the wren nested in Franklin County, although it has not been recorded there in recent years.

\section{Reptiles}

Bog turtle, Clemmys muhlenbergi (C2, SE): The turtle is prevalent in the Susquehanna drainages where it ranges through Franklin, Adams, and Cumberland Counties. It is likely to be found on or around the installation.

Red-bellied turtle, Pseudemys rubriventris (SE): This species was found on the west branch of Conococheaque Creek, in Franklin County, about $8 \mathrm{~km}$ from the installation. The turtle may be found in other drainages around the installation.

\section{Mammals}

Eastern small-footed bat, Myotis subulatus leibii (C2, SE): Historically recorded in Franklin County, the bat inhabits caves or mines. It may be seen migrating or as a transient on the installation.

Indiana bat, Myotis sodalis (FE): Historically, this bat was recorded in Franklin County. The bats have not been recorded in Pennsylvania in the winter. They may be seen migrating in the area. The bat is listed as possibly occurring in surrounding counties of the installation as well. 


\section{INVERTEBRATES}

Buckmoth, Hemileuca maia (ST): This species was collected in Fayetteville, Franklin County. This is about $16 \mathrm{~km}$ southeast of the installation. The moth is found in open scrub oak barrens, almost always on sandy soil.

\section{Endangered Species Summary}

No federal species are known on the installation. The eastern small-footed and Indiana bats may occur in the area. The peregrine falcon could be a rare migrant. The Henslow's and grasshopper sparrows are state threatened species known to occur on the installation. The upland sandpiper, and Bewick's wren may be seen in the area. The bog and red-bellied turtles have been recorded in drainages around the installation. The buckmoth is an insect that may be found in the area. 
LEXINGTON/BLUEGRASS AMC 14,000 Acres $\quad$ Kentucky

Main Counties: Fayette and Bourbon (LEXINGTON ACTIVITY)

Surrounding Counties: Bath, Clark, Harrison, Nicholas, Jessamine, Madison, Montgomery, Scott, Woodford

Main Counties: Madison (BLUEGRASS ACTIVITY)

Surrounding Counties: Clark, Estill, Fayette, Garrard, Jackson, Jessamine, Powell, Rockcastle

\section{VERTEBRATES}

Birds

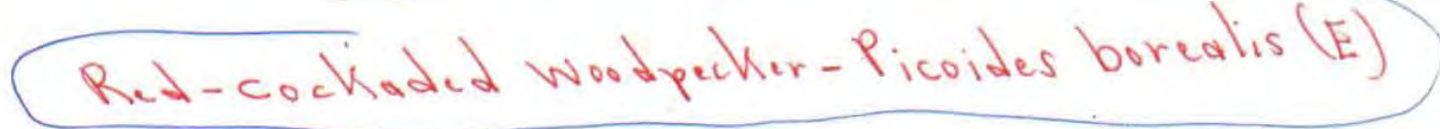

Bachman's sparrow, Aimophila aestivalis (C2, ST): Listed in Madison County, this sparrow is a rare summer resident. Its preferred habitat includes open pastures, thick grass with low trees, open grassy woodlands, and old fields.

Upland sandpiper, Bartramia longicauda (SE): Historical records indicate this species was recorded during spring migrations in Woodford County, and fall migrations around Lexington and other areas in Fayette County. A rare to uncommon transient in Kentucky, it may be seen on the installation around open grassland areas.

American bittem, Botaurus lentiginosus (SE): Historical records indicate this species was found in Bourbon County and other areas around Lexington. Considered a rare to uncommon transient, the bitterns are often encountered in cattail marshes.

Lark sparrow, Chondestes grammacus (SE): In Kentucky this bird is a rare spring transient and summer resident. It was recorded as nesting in Madison and Fayette Counties (Harrison City, 1985). Although generally considered a grassland bird, it will occupy rocky outcrops or areas with sparse ground cover mixed with rock.

American peregrine falcon, Falco peregrinus anatum (FE, SE): An extremely rare transient and winter visitor. It is possible this species could be seen on the installation. Historically this bird was recorded in Powell County in areas where nesting was possible.

Arctic peregrine falcon, Falco peregrinus tundrius (FE, SE): An extremely rare transient and winter visitor. It is possible this species could be seen on the installation.

American coot, Fulica americana (SE): In Kentucky, the coot is a fairly common spring and fall migrant, an uncommon winter resident and a very rare summer resident/nesting species. Breeding has been documented in Fayette county.

Southern bald eagle, Haliaeetus leucocephalus leucocephalus (FE, SE): This species is known in Woodford County. Wintering eagles are probably the northern subspecies.

Black-crowned night heron, Nycticorax nycticorax (SE): A rare to uncommon transient and local summer resident. These birds are generally found near swamps. 
Yellow-crowned night heron, Nycticorax violacea (ST): An uncommon transient and summer resident. Historical records indicate this bird nested in Fayette county. The herons are usually found in forested areas near swamps or sloughs, and may be seen on the installation.

Osprey, Pandion haliaetus (SE): A common transient throughout the state of Kentucky, the ospreys are found near ponds, lakes, and streams. Their occurrence around the installation in the spring or fall is possible.

Pied-billed grebe, Podilymbus podiceps (SE): This grebe is a fairly common to common transient, a rare winter and summer resident. It was recorded as a spring migrant in Lexington. It may be seen in marshy areas on or near the installation at these times.

Appalachian Bewick's wren, Thryomanes bewickii altus (C1): A rare summer resident throughout Kentucky, it usually nests in farmlands, small towns and clearings. Occurrence on the installation is possible.

Loggerhead shrike, Lanius ludovicianus migrans (C2): An uncommon to fairly common resident, the shrike may be found in areas on or around the installation. This bird is found in a variety of semi-open and open habitats.

\section{Mammals}

Red wolf, Canis rufus gregoryi (FE): Although only 40 individuals of this species remain in captivity, the installation is within its historic range, which included the entire southeast.

Eastern cougar, Felis concolor coryi (FE, SE): Although this species is very rare, if not extinct, its historical range is within the area of the installation. Wild populations still may exist, making occurrence on the installation possible, although unlikely.

Gray bat, Myotis grisescens (FE, SE): This bat is mainly a cave-dweller and is known to have nursery colonies in Garrard and Jessamine Counties. It also is known to occur in Jackson County. Occurrence on the installation during nocturnal foraging is likely.

Indiana bat, Myotis sodalis (FE, SE): Known in Estill, Jackson, Rockcastle, and Powell Counties, this species could occur in all main and surrounding counties, where they overwinter in caves. The bats may be seen during migration or foraging in riparian areas around the installation.

Eastern woodrat, Neotoma floridana magister (C2): Between 1982 and 1988 this species was recorded in Estill, Jackson, Jessamine, Madison, Montgomery, Powell, and Rockcastle Counties. The status of these populations has not been evaluated. The woodrats generally inhabit areas with rocky outcrops. The species may inhabit areas near the installation.

Evening bat, Nycticeius humeralis (SE): Uncommon summer resident ranging in the western and southern part of Kentucky, the evening bat is usually found in buildings and tree cavities. Occurrence on the installation is possible.

Big-eared Virginia bat, Plecotus townsendii virginianus (FE, SE): This bat is found in Jackson and Rockcastle Counties, and was recorded hibernating in a small cave.in Powell County. The same cave is probably used during the summer and winter. Occurrence in transit or foraging on the installation is possible. The species is highly intolerant of human disturbance. 
Pygmy shrew, Microsorex hoyi winnemana (C2): This shrew has been collected within the area in the past. It has been found in various habitats, including bogs, woods, grassy fields, and brushy areas on forest edges.

Eastern small footed bat, Myotis sublatus leibii (C2, SE): This species may be found foraging or migrating on or around the installation. The bat may be found in old mines and buildings as well as caves.

Rafinesque's big-eared bat, Plecotus rafinesqui $(\mathrm{C} 2, \mathrm{ST})$ : This bat may be seen foraging or migrating in the area. It has been recorded for the past 10 years in Estill, Jackson, Powell, and Rockcastle Counties.

\section{Fish}

Eastern sand darter, Ammocrypta pellucida (C2): Listed in Madison County, this species is historically known from the Kentucky River around the middle fork. Its occurrence in waters around the installation is possible.

\section{Amphibians}

Hellbender, Cryptobranchus alleganiensis (C2): The hellbender may be found in drainages around the installation.

\section{Endangered Species Summary}

The bald eagle and Indiana and gray bats are the only federally endangered species likely to be seen on either complex. The big-eared Virginia bat may also occur. Several candidate or state listed species may breed or reside in the area, including Bachman's sparrow, alrk sparrow, two night herons, Bewick's wren, eastern wood rat, pygmy shrew, eastern sand darter, and hellbender. The evening, eastern small footed, and Rafinesque's big-eared bats may forage on or migrate through the area. 
FORT MCCLELLAN TRADOC 46,110 Acres Alabama

Main County: Calhoun

Surrounding Counties: Cherokee, Clay, Cleburne, Etowah, St. Clair, Talladega

\section{VERTEBRATES}

Birds

American peregrine falcon, Falco peregrinus anatum (FT, ST): This falcon is a transient species in Alabama and migrates mainly along the Gulf Coast. Occurrence on the installation is unlikely but possible.

Arctic peregrine falcon, Falco peregrinus tundrius (FT, ST): This bird is a transient species in Alabama and migrates mainly along the Gulf Coast. Occurrence on the installation is unlikely but possible.

Southern bald eagle, Haliaeetus leucocephalus leucocephalus (FE, SE): There is a known occurrence of this species in adjacent Cherokee County. Because the birds may range widely to forage, an occurrence on or near the installation is possible.

Red-cockaded woodpecker, Picoides borealis (FE, SE): This species occurs within Calhoun County and could occur within the installation if suitable pine stands were available. The woodpeckers have occurred on the installation in the past.

Appalachian Bewick's wren, Thryomanes bewickii altus (C1, ST): This bird is uncommon as a summer resident in Alabama. In winter it is uncommon to fairly common. Occurrence on the installation is possible year round, but most likely in the winter.

Bachman's warbler, Vermivora bachmani (FE, SE): This species was once a rare spring transient in central to northern Alabama. The bird has not been seen in the mountain region (north-central) of Alabama since the late 1950 s and is thought to be extinct.

\section{Mammals}

Red wolf, Canus rufus gregoryi (FE): Although this species is extirpated in Alabama, the installation is within its historic range.

Florida panther, Felis concolor coryi (FE, SE): Although this species is probably extirpated in Alabama, the installation is within its historic range. Wild populations still exist, making the occurrence of this species possible.

Gray bat, Myotis grisescens (FE, SE): The installation is within the range of this species and occurrence as a transient is possible. Important caves for hibernating bats occur within $100 \mathrm{~km}$ of the Anniston Army Depot adjacent to Fort McClellan.

Indiana bat, Myotis sodalis (FE, SE): Occurrence of this species is possible in Calhoun and the six surrounding counties. Maternity colonies could occur around dead trees within riparian areas. Important caves for hibernating bats occur within $100 \mathrm{~km}$ of the Anniston Army Depot adjacent to Fort McClellan. 
Fish

Pygmy sculpin, Cottus pygmaeus (FT, ST): This species is only known within nearby Coldwater Spring, which is outside the city of Anniston and within $3 \mathrm{~km}$ of the installation.

Coldwater darter, Etheostoma boschungi (C2): This fish is known to occur in Coldwater Spring (less than $8 \mathrm{~km}$ from the installation) and other areas of the upper Coosa River System.

Blue shiner, Notropis caeruleus (C2): Populations occur in Shoal and Chocolocco Creeks in Calhoun County. Stretches of these creeks are less than $8 \mathrm{~km}$ from the installation.

\section{INVERTEBRATES}

\section{Mollusks}

Upland combshell, Epioblasma metastriata (C2): This species was recorded from Chocolocco Creek, 11 $\mathrm{km}$ southwest of Eastaboga, Alabama and in the Coosa River $5 \mathrm{~km}$ southeast of Ragland, Alabama. Although these areas are less than $16 \mathrm{~km}$ from the installation, no specimens were found in a 1971-1973 study of the Coosa River Drainage.

Fine-lined pocketbook, Lampsilis altilis (C2): This species was found in the early 1970s in Choccolocco Creek, $3 \mathrm{~km}$ south of White Plains (Calhoun County), Alabama. This area is less than $1.6 \mathrm{~km}$ from the installation.

Tennessee heelsplitter, Lasmigona holstonia (C2): This species was found in the early 1970s in Shoal Creek, $5 \mathrm{~km}$ southeast of White Plains (Calhoun County), Alabama. This is less than $1.6 \mathrm{~km}$ from the installation.

Judge Tait's mussel, Pleurobema taitianum (FE): Historical records indicate this species occurred within the Coosa River drainage. Modification and pollution of the river has made its occurrence in this area unlikely.

Purple lilliput, Toxoplasma lividus (C2): Historical records indicate that this mussel was found in Choccolocco Creek, $3 \mathrm{~km}$ south of White Plains (Calhoun County), Alabama. This area is less than 1.6 $\mathrm{km}$ from the installation.

Alabama livebearing snail, Tulotoma magnifica (C2): Historical records show this species was collected along the Coosa River drainage. It still may occur on Chocolocco Creek. It has been listed as occurring in St. Clair and Talladega Counties.

Sculpin snail, Stiobia nana (C2): This species is found in Coldwater Spring in Calhoun County.

\section{Endangered Species Summary}

The recently listed pygmy sculpin and the red-cockaded woodpecker are the species most likely to be found within the area. Sightings of Indiana and gray bats are also possible. No state or federally listed 
threatened or endangered species are known to occur presently. The red-cockaded woodpecker could occur if suitable pine stands were present. The pygmy sculpin and Indiana bat should also be looked for. Federally endangered bald eagles and gray bats may occur as transients. The state listed Berwick's wren could be present, especially in the winter. Several candidate fish and mollusk species may be present. 
FORT McCOY FORSCOM 60,916 Acres Wisconsin

Main County: Monroe

Edge County: Jackson

Surrounding Counties: Juneau, LaCrosse, Vernon

\section{VERTEBRATES}

\section{Birds}

Red-shouldered hawk, Buteo lineatus (ST): This species is a summer resident within $15 \mathrm{~km}$ of the installation.

Great egret, Casmerodius albus (ST): The egret is a visitor and a summer resident in areas adjacent to the installation, making its occurrence on Fort McCoy possible.

Piping plover, Charadrius melodius (FE, SE): The plover has been recorded in LaCrosse and Vernon Counties from July to August. Its occurrence as a migrant on the installation is possible.

Cerulean warbler, Dendroica cerulea (ST): Found in areas less than $25 \mathrm{~km}$ to the southwest, this species may occur on the installation.

Yellow-throated warbler, Dendroica dominica (SE): This bird may occur as a migrant on the installation.

Kirtland's warbler, Dendroica kirtlandii (FE): Jack-pine stands, which are potential breeding habitat, exist for this bird on the installation. However, populations are unknown in the area.

Acadian flycatcher, Empidonax virescens (ST): The flycatcher has been recorded as a migrant on and around the installation.

American Peregrine falcon, Falco peregrinus anatum (FE, SE): Falcons are known as visitors and migrants on the installation.

Arctic peregrine falcon, Falco peregrinus tundrius (FT): These falcons may be seen as migrants on or around the installation.

Northern bald eagle, Haliaeetus leucocephalus alascanus (FT, SE): Eagles are known migrants and visitors on the installation.

Migrant loggerhead shrike, Lanius ludovicianus migrans (C2, SE): This species is a summer resident within a $16-\mathrm{km}$ radius of Fort McCoy.

Kentucky warbler, Oporornis formosus (ST): This species has been recorded as a migrant on and around the installation.

Osprey, Pandion haliaeetus (SE): This bird is known to breed on the installation. 
Red-necked grebe, Podiceps grisegena (SE): This bird may occur as a migrant on the installation.

Caspian tern, Sterna caspia (SE): This species has been recorded as a migrant on the installation.

Forster's tern, Sterna forsteri (SE): This species is known to occur on the installation as a migrant and a visitor.

Bell's vireo, Vireo bellii (ST): This species may occur on the installation as a transient.

\section{Reptiles}

Wood turtle, Clemmys insculpta (ST): This turtle is known to occur on the installation. Generally it is found in forested areas along fast moving streams.

Blanding's turtle, Emydoidea blandingi (ST): Known to occur on the installation. The turtle forages on both land and in shallow water, and seems to prefer open grasswater marshes.

Western slender glass lizard, Ophisaurus attenuatus (SE): This lizard is known to occur on the installation. It is generally found in oak savannas and prairies.

Eastern massasauga, Sistrurus catenatus (C2, SE): Recorded in areas less than $16 \mathrm{~km}$ north to northeast of the installation, the massasauga inhabits lowland areas along rivers, and adjacent open fields. Occurrence of this snake on the installation is possible.

\section{Amphibians}

Blanchard's cricket frog, Acris crepitans (SE): This frog, which inhabits marshes along rivers and river floodplains, is known to occur on the installation.

\section{Fish}

River redhorse, Moxostoma carinatum (ST): Activities on the installation may affect this fish, which has been recorded in the Black River within a 16-km radius of Fort McCoy.

Redfin shiner, Notropis umbratilis (ST): Locally rare to common, historically, the shiner was found in waters $5 \mathrm{~km}$ west of the installation.

Gilt darter, Percina evides (ST): Activities on the installation may affect this fish, which has been recorded in the Black River within $25 \mathrm{~km}$ of the installation.

\section{INVERTEBRATES}

Karner blue butterfly, Lycaeides melissa samueli (C2): Known to occur on the installation, and generally found in undisturbed prairie areas. 
Giant carrion beetle, Nicrophorus americanus (FE, SE): Historically, this species was recorded in areas less than $16 \mathrm{~km}$ northwest of the installation.

Elusive clubtail, Stylurus notatus (C2): This species was recorded about $16 \mathrm{~km}$ northwest of the installation.

\section{Endangered Species Summary}

The bald eagle and the peregrine falcon are known migrants and visitors on the installation. Potential breeding habitat exists for the Kirtland's warbler. The osprey is known to breed on the installation. Other known state listed species include the Karner Blue butterfly, Blanchard's cricket frog, the western slender glass lizard, Blanding's turtle, and the wood turtle. The Caspian tern, Forster's tern, Kentucky warbler, and the Acadian flycatcher are known state listed migrants on the installation. 
MILAN AAP AMC 22,541 Acres Tennessee

Main Counties: Gibson, Carroll

Surrounding Counties: Benton, Crockett, Dyer, Henderson, Henry, Madison, Obion, Weakley

\section{VERTEBRATES}

\section{Birds}

Cooper's hawk, Accipiter cooperii (ST): Although it is rare, this hawk is considered a permanent resident throughout Tennessee and may be found anywhere in the state. It has been recorded in Gibson County from April through August and is most likely to be seen on the installation from September through November when additional migrants from the north are present.

Sharp-shinned hawk, Accipiter striatus (ST): An uncommon to rare permanent resident which may be found in any Tennessee County, this hawk has been recorded at various times of the year in Gibson and Carroll Counties. It may be found within the installation.

Bachman's sparrow, Aimophila aestivalis* (C2, SE): This species usually inhabits open pastures with thick grasses, and few low trees. Open oak and pine woodlands may also be used.

Grasshopper sparrow, Ammodromus savannarum (ST): This species is listed as occurring in Gibson County. Formerly a fairly common to common summer resident and transient throughout Tennessee, it was found in Gibson County from May through September and is now an uncommon to rare winter visitor.

Great blue heron, Ardea herodias* (ESD: ST, S3): An uncommon to rare permanent resident, the great blue has been recorded in Gibson County from September through February. These birds require freshwater marsh areas for breeding and feeding.

American ivory-billed woodpecker, Campephilus principalis principalis (FE/ESD: SP): Although this bird is thought to be extinct, it was once found throughout the southeast. Historical records for Tennessee are sketchy, but the installation is probably within its historic breeding range.

Northem harrier, Circus cyaneus hudsonius (ST): Throughout the state, this bird is an uncommon to rare transient in spring and fall and an uncommon to rare winter visitor. It was recorded from August to May in Gibson and Carroll Counties, its occurrence on the installation is possible.

American peregrine falcon, Falco peregrinus anatum (FE, SE): This species was a rare to uncommon local resident, and breeding bird at Reelfoot Lake. Presently, it is an uncommon to rare transient in spring and fall and a very rare wintering bird. Its occurrence on the installation is possible.

The Ecological Services Division (ESD) of the Tennessee Department of Conservation maintains a separate listing of threatened and endangered species that may differ from the state list maintained by the Tennessee Wildlife Resources Agency. 
Arctic peregrine falcon, Falco peregrinus tundrius (FE, SE): This subspecies migrates through the area and may be seen on the installation.

Bald eagle, Haliaeetus leucocephalus (FE, SE): Eagles are known to occur in Benton, Dyer, Henry, and Obion Counties. Because the birds may range widely to forage, an occurrence on or near the installation is possible. Some of the wintering birds may be of the northern subspecies alascanus. None have nested in Tennessee since 1958.

Least bittern, Ixobrychus exilis (ESD: ST): An uncommon to rare transient across the state during April and May and again in September and October, bitterns inhabit freshwater marshes and pond edges. These birds have been recorded in Stewart and Montgomery Counties from April through mid-October.

Black-crowned night heron, Nycticorax nycticorax (ST/ESD: ST): An uncommon to rare permanent resident throughout Tennessee, this night heron was recorded in Carroll County from March to August. These birds will nest in pine stands and are usually found in marshes, swamps, creeks, and wooded streams.

Yellow-crowned night heron, Nycticorax violaceus (ESD: ST): Usually found in forested areas near swamps or sloughs, this heron has been recorded in Carroll County from March to August. This species has also been recorded as nesting in the county. Occurrence on the installation is possible.

Red-cockaded woodpecker, Picoides borealis (FE, SE/ESD: SE): The historical range of this woodpecker included the installation. It requires mature pine stands.

King rail, Rallus elegans (ESD: SE, S2): An uncommon to rare transient and an uncommon to rare summer resident, the rail is mainly found in marshy habitats. This bird has also been recorded in Caroll County from April through July.

Virginia rail, Rallus limicola (ESD: SE): An uncommon to rare transient and a rare winter visitor across Tennessee, the rail is also a rare and local summer resident. It has been recorded in Carroll County from August through July. The birds breed in freshwater marshes and marshy fields but are sometimes found in drier brushy fields during migration.

Interior least tem, Sterna antillarum antillarum (FE, SE/ESD: SE): This species is known to occur in Dyer county. Although this species is an uncommon to rare transient in areas away from the Mississippi River, its occurrence on the installation is possible.

Appalachian Bewick's wren, Thryomanes bewickii altus (C1, ST): A permanent resident across the state, this bird was recorded from March through August in Gibson and Carroll Counties. The birds are usually found in thickets, brush piles, fence and hedgerows and other areas with second growth.

Bachman's warbler, Vermivora bachmani (FE, ESD: SP): Considered the rarest warbler in North America, this bird's historical range was recorded throughout the southeast. Confirmed breeding sites were in Kentucky and South Carolina. Historically, this bird was probably at least a migrant through the area where the installation is located. 


\section{Reptiles}

Copperbelly water snake, Nerodia erythrogaster neglecta (C2): Listed as occurring in Carroll County, Tennessee. The Tennessee Heritage Program says it is not in the county.

Alligator snapping turtle, Macroclemys temmincki (C2): Found in Tennessee west of Kentucky Lake, this turtle inhabits rivers, sloughs, and occasionally marshes or swamps. It usually prefers larger, deeper streams. Its occurrence on the installation in the Rutherford Fork is possible.

\section{Mammals}

Red wolf, Canus rufus gregoryi (FE): Although the wolf is extirpated in Tennessee, the installation is within its historic range.

Eastern cougar, Felis concolor cougari (FE, SE/ESD: SE): This species is very rare, however, the installation is within its historic range. Wild populations of the cougar are thought to persist, making the occurrence on the installation possible, although unlikely.

River otter, Lutra canadensis (ST/ESD: ST): Listed as occurring in Gibson County, the river otter is usually found in streams, rivers, and lakes usually bordered by woods. The occurrence of the otter on the installation is possible, although unlikely.

Gray bat, Myotis grisescens (FE, SE/ESD: SE): The bats may be seen foraging while migrating through riparian areas of the installation.

Indiana bat, Myotis sodalis (FE, SE/ESD: SE): The Indiana bat possibly occurs in both the main and surrounding counties. This species would most likely be seen foraging around riparian areas.

Southeastern big-eared bat, Plecotus rafinesquii (C2): Associated with forested regions, unoccupied buildings, and other man-made structures, this bat has been recorded in Gibson County. Its occurrence on the installation is possible.

\section{Endangered Species Summary}

No federally listed species are known to occur on the installation, but several may be found as transients. These include the bald eagle, peregrine falcon, interior least tern, and Indiana bat. State listed species that may be found include the Cooper's and sharp-shinned hawks, northern harrier, rails, bitterns, herons, night herons, grasshopper sparrows, and the Bewick's wren. The alligator snapping turtle and the river otter are also of concern. 


\section{MISSISSIPPI AAP AMC $\quad \mathbf{6 , 0 0 0}$ Acres $\quad$ Mississippi}

Main County: Hancock

Edge Counties: Pearl River, MS; St. Tammany Parish, LA (buffer zone extends into this county); Surrounding Counties: Harrison, Stone

\section{VERTEBRATES}

Birds

American ivory-billed woodpecker, Campephilus principalis principalis (FE, SE): Although this subspecies of the ivory-billed is probably extinct, its historical range includes the installation.

American peregrine falcon, Falco peregrinus anatum (FE, SE): These birds migrate along the Atlantic and Gulf coasts, and may occur on the installation.

Arctic peregrine falcon, Falco peregrinus tundrius (FT, SE): These birds migrate along the Atlantic and Gulf coasts. Their occurrence on the installation is possible.

Southern bald eagle, Haliaeetus leucocephalus leucocephalus (FE, SE): A bald eagle nest has recently been discovered within the Bay St. Louis area. The eagle's historical range is within the area of the installation. Eagles may travel far from their nesting area to forage, especially in riparian areas. Their occurrence on or around the installation is possible.

Brown pelican, Pelecanus occidentalis carolinensis (FE, SE): Brown pelicans range within the area of the installation. Their occurrence as transients is possible.

Red-cockaded woodpecker, Picoides borealis (FE, SE): The range of the woodpecker is within the area of the installation, and requires mature pine forests (greater than 60 or 70 years old) for nesting. If such conditions exist, the birds could be found on the installation.

Bachman's warbler, Vermivora bachmainii (FE, SE): Historically this warbler was recorded as a transient through the area. The Bachman's warbler has not been seen in the southeast in recent years.

\section{Reptiles}

American alligator, Alligator mississippiensis (FTSA, SE): Alligators are commonly found in large drainage systems on the NASA test site to the south of the installation. Historically, their range included the southern portion of Mississippi, and they could occur on the installation.

Eastem indigo snake, Drymarchon corais couperi (FT, SE): Historically, this snake ranged within the area of the installation; an unconfirmed sighting was made on the installation in 1974. Otherwise, the occurrence of this species in Mississippi is unknown.

Rainbow snake, Farancia erytrogramma (SE): Found in slough and stream habitats, this species is uncommon in the region. Its occurrence on the installation is possible. 
Gopher tortoise, Gopherus polyphemus (FT, SE): The tortoises reach their farthest western range in Hancock County. Occurrence on the installation is possible.

Ringed sawback turtle, Graptemys oculifera (FT, SE): Found in the Pearl River and its larger tributaries, the occurrence of this species on or around the installation is possible.

Black pine snake, Pituophis melanoleucus lodingi (C2, SE): Associated with longleaf pine stands, this species was recorded at Poplarville in Pearl River County. Its occurrence on the installation is possible.

\section{Mammals}

Red wolf, Canis rufus gregoryi (FE): Although this species has been extirpated from Mississippi, the installation is within its historic range.

Florida panther, Felis concolor coryi (FE, SE): This species historically occurred within the area, although it is now very rare. Wild populations still exist, making the occurrence on the installation possible.

Louisiana black bear, Ursus americanus luteolus $(\mathrm{C} 1)$ : The bear is found within the area and may be seen on the installation.

\section{Fish}

Gulf sturgeon, Acipenser oxythynchus desotoi (C2): This species was collected from the Pearl and Mikes Rivers. Its occurrence within waters of the installation is likely.

Atlantic sturgeon, Acipenser oxythynchus (SE): This species was collected from the Pearl and Mikes Rivers. Its occurrence within waters of the installation is likely.

Frecklebellied madtom, Noturus munitus (C2, SE): Generally found upstream from tidal intrusions, this fish has been collected from the Jourdan River and Catahoula Creek. These areas are less than $8 \mathrm{~km}$ from the installation.

\section{Amphibians}

Dusky gopher frog, Rana areolata sevosa (C2): Historically collected in the Biloxi area, this species has been difficult to locate even at known breeding sites. Its occurrence on the installation is possible.

\section{Endangered Species Summary}

Although no federally listed species are known on the installation, bald eagles and red-cockaded woodpeckers may occur as transients. The eastem indigo snake, gopher tortoise, and ringed sawback turtle may also be found. Rare transient birds include the peregrine falcon and brown pelican. Waters around the installation may support the Atlantic sturgeon and frecklebellied madtom, which are state listed species. Other species of concern include the black pine snake, dusky gopher frog, and the American alligator. 
Main County: Vermillion

Surrounding Counties: Parke, Vigo, Warren, IN; Edgar, Vermilion, IL

\section{VERTEBRATES}

Birds

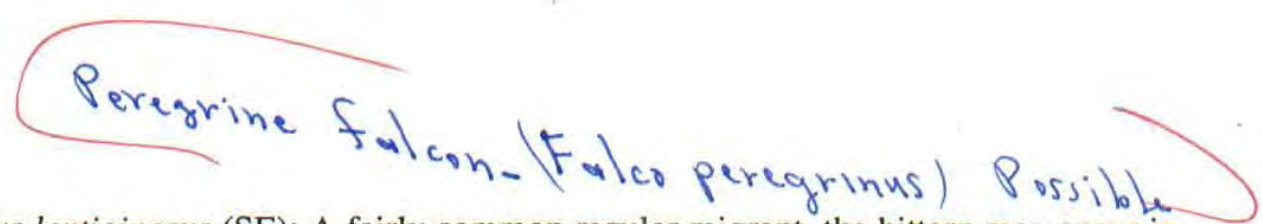

American bittern, Botaurus lentiginosus (SE): A fairly common regular migrant, the bittern may occur in marshland areas of the installation.

Great egret, Casmerodius albus (SE): A species that declined mainly because of overhunting, the egret is a rare spring migrant and uncommon fall migrant most often seen in its post-breeding wandering period, August to September. Its occurrence on the installation in marsh areas is possible.

Northern harrier, Cirus cyaneus (SE): An uncommon migrant and rare permanent resident in Indiana, this bird may be found on the installation.

Sedge wren, Cistothorus platensis (ST): A locally common migrant and summer resident, the wren historically nested in Parke County. Its occurrence on the installation is possible.

Northern bald eagle, Haliaeetus leucocephalus alascanus (FE, SE): The eagle occurs within a 3-km radius of the installation. The eagles are most likely seen along the Wabash River as they migrate through the area.

Migrant loggerhead shrike, Lanius ludovicianus migrans (C2, SE): A rare migrant and very rare summer resident, its occurrence on the installation is possible. Recent breeding localities have been recorded in Parke and Vigo Counties in 1983 and 1979, respectively.

Black-crowned night heron, Nycticorax nycticorax (SE): A rare migrant and casual winter resident, the heron may be found in marsh areas of the installation.

Yellow-crowned night heron, Nycticorax violaceus (SE): A casual to rare migrant and summer resident, this bird was recorded nesting in Vigo County in 1985. Its occurrence in marsh areas of the installation is possible.

Osprey, Pandion haliaetus (SE): A rare to uncommon migrant throughout Indiana, this bird was recorded nesting in Parke County on Raccoon Lake in 1971. Its occurrence on waters around the installation is possible.

Common barn owl, Tyto alba (SE): A permanent resident in various areas of the state, the barn owl may be found on or near the installation in man-made structures such as barns or storage buildings. 


\section{Reptiles}

Kirtland's snake, Clonophis kirtlandii (C2, ST): Historically, this species was recorded in Parke and Vigo Counties. Its occurrence on the installation is possible.

\section{Mammals}

Indiana bat, Myotis sodalis (FE, SE): Generally seen in the fall, this bat has been recorded in Parke and Vigo Counties.

Evening bat, Nycticeius humeralis (SE): Although this species is an uncommon summer resident, a hibernating colony of 358 bats was discovered in 1987 in Vigo County. The occurrence of this species on the installation is possible.

\section{Fish}

Eastern sand darter, Ammocrypta pellucida (C2): Historically collected from the Wabash River, this species has been recorded in waters within a $3-\mathrm{km}$ radius of the installation.

Blue sucker, Cycleptus elongatus (C2): Recorded in the Wabash River in 1981, this species may be found in waters around the installation.

\section{INVERTEBRATES}

\section{Mollusks}

Fanshell, Cyprogenia stegaria (FPE, SE): This mussel has been found in the Wabash River. Its occurrence in waters around the installation is possible.

White catspaw, Epioblasma obliquata perobliqua (FPE, SE): A rare mussel in the Wabash River, its occurrence in waters around the installation is possible.

Northern riffleshell, Epioblasma torulosa rangiana (C2, SE): Historically recorded in the Wabash and White Rivers, this mollusk may be found in waters around the installation.

Snuffbox, Epioblasma triquetra (SE): Historically recorded in the Wabash River, this species may be found in waters around the installation.

Long-solid, Fusconia subrotunda (SE): This species was historically found in the Wabash River, and may be found in waters around the installation.

White wartyback, Plethobasus cicatricosus (FE, SE): This mussel has been found in the Wabash River and may occur in waters around the installation. 
Sheepnose, Plethobasus cyphyus (SE): Historically recorded in the Wabash River, this species may be found in waters around the installation.

Clubshell, Pleurobema clava (C2, SE): Historically recorded in the Wabash River, this species may be found in waters around the installation.

Rough pigtoe, Pleurobema plenum (FE, SE): This mussel was collected up to 1974 in the Wabash River.

Fat pocketbook pearly mussel, Potamilus capax (FE, SE): The Wabash River in Vermillion County is included in the official range. Live specimens have recently been located in the lower Wabash.

\section{Other}

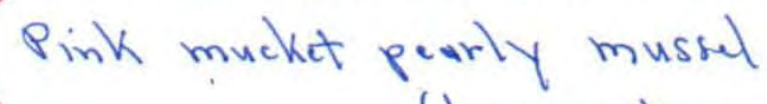

Kamer blue butterfly, Lycaeides melissa samuelisy $(C 2, S E)$ : Recorded in Parke County, this be found on the installation.

\section{Endangered Species Summary}

The bald eagle is known to occur within a 3-km radius of the installation. The eastern sand darter has also been recorded in waters around the installation. The Indiana Bat may forage in riparian areas. Several state listed bird species may occur. Several mollusk species may be found in waters around the installation. Other species to look for include Kirtland's snake, the two bat species, two fish species, and the Karner blue butterfly. 


\section{PICATINNY ARSENAL AMC 6,491 Acres New Jersey}

Main County: Morris

Surrounding Counties: Essex, Hunterdon, Passaic, Somerset, Sussex, Union, Warren

\section{VERTEBRATES}

Birds

Cooper's hawk, Accipiter cooperii (SE): Known as an irregular visitor on the installation, this hawk is a year-round resident in Morris County. This species is found primarily in mature forests or open woodland and forest edges. Known to breed in Morris County, its occurrence on the installation is possible.

Northem goshawk, Accipiter gentilis (ST): This species is known to occur on the installation as a winter resident. The goshawk inhabits forest edges and open woodlands, also foraging in cultivated regions. Known to breed in Morris County, its occurrence on the installation as a breeding species is possible.

Grasshopper sparrow, Ammodramus savannarum (ST): Known to breed in Morris County, this sparrow is found in prairies, old fields and open grasslands. Its occurrence on the installation is possible.

Great blue heron, Ardea herodias (ST): Known as a permanent resident on the installation, the heron may be found in marshes or fields.

Short-eared owl, Asio flammeus (SE): Found in open country including marshes and open woodlands, this owl may be found in Morris County. Its occurrence on the installation is possible.

Upland sandpiper, Bartramia longicauda (SE): This species has an irregular occurrence on the installation. It is generally found in grassland areas, especially dry meadows and pastures.

American bittem, Botaurus lentiginosus (SE): Known as a migrant on the installation, the bittern may be found in marsh areas or wet fields. Known to breed in Morris County, its occurrence on the installation is possible.

Red-shouldered hawk, Buteo lineatus (ST): This species is an irregular transient on the installation. Usually found around wooded swamps and open woodlands. Known to breed in Morris County, its occurrence on the installation is possible.

Northem harrier, Circus cyaneus (SE): Known as a migrant on the installation, the harrier may be found in marsh or grassland areas.

Sedge wren, Cistothorus platensis (SE): A summer and fall resident as well as a breeder in New Jersey, this species may be found in grasslands and marshes in Morris County. Its occurrence on the installation possible.

Bobolink, Dolichonyx oryzivorus (ST): Known to breed in Morris County, this bird may be found in tall grass, marsh, or open woody areas of the installation.

American peregrine falcon, Falco peregrinus anatum (FE, SE): Known throughout the state, breeding populations are being reestablished. This species may be seen on the installation. 
Arctic peregrine falcon, Falco peregrinus tundrius (FT, SE): Known as a migrant throughout the state, this species may be seen on the installation.

Northern bald eagle, Haliaeetus leucocephalus (alascanus) (FE, SE): An irregular visitor to the installation, the eagle may be found around waters of the installation.

Cliff swallow, Hirundo pyrrhonota (SE): Known to occur on the installation as a migrant, the swallow may be found in flocks around bodies of water.

Black rail, Laterallus jamaicensis (ST): Known to breed in Morris County, the rail may be seen as a transient in marsh areas of the installation.

Red-headed woodpecker, Melanerpes erythrocephalus (ST): A rare resident in the state, the woodpecker may be found in Morris County and may occur on or around the installation. This bird is found in open woodland areas, especially with beech or oak trees and open areas with scattered trees.

Yellow-crowned night heron, Nycticorax violaceus (ST): An uncommon summer resident, the heron was recorded in Great Swamp National Wildlife Refuge in 1980. Its occurrence in marsh areas of the installation is possible.

Osprey, Pandion haliaetus (ST): A known migrant on the installation, the osprey may be seen as a transient around stream or lake areas of the installation.

Savannah sparrow, Passerculus sandwichensis (ST): This species occurs on the installation as a migrant.

Pied-billed grebe, Podilymbus podiceps (SE): This species occurs as a migrant on the installation. The grebe may be found in lakes, ponds, and marshes.

Vesper sparrow, Pooecetes gramineus (SE): Known as a migrant on the installation.

Barred owl, Strix varia (ST): A permanent resident on the installation. It is usually found in wooded areas bordering streams or swamp areas.

\section{Reptiles}

Wood turtle, Clemmys insculpta (ST): A permanent resident on the installation, the turtle inhabits swamp or riparian areas.

Bog turtle, Clemmys muhlenbergi (C2, SE): Known as a permanent resident on the installation, the turtle inhabits swamp or riparian areas.

Timber rattlesnake, Crotalus horridus (SE): This species occurs as a permanent resident on the installation. Generally found in wooded rocky hillsides and swampy areas, the snake was collected on Green Pond Mountain in the summer of 1986.

\section{Mammals}

Mountain lion, Felis concolor cougari (FE): Although thought to be extirpated from New Jersey, historically, the lion was found in this area. 
Eastern woodrat, Neotoma floridana magister (C2, ST): Populations of this species are known to occur on the arsenal.

New England cottontail, Sylvilagus transitionalis (C2): The cottontail occurs within the range of the installation and may be seen there.

\section{Amphibians}

Blue-spotted salamander, Ambystoma laterale (SE): Known to occur in Morris County with populations in the Great Swamp National Wildlife Refuge. May be found in overgrown pastures or in sandy areas. Its occurrence on the installation is possible.

Tremblay's salamander, Ambystoma tremblayi (SE): Known to occur in Morris County, this species may be found in overgrown pastures or in sandy areas. Its occurrence on the installation is possible.

Longtail salamander, Eurycea longicauda (ST): Known to occur in Morris County, this species may be found on the installation. The salamander inhabits streambanks or spring runs and may disperse into wooded terrestrial habitats in wet weather. Generally, it hides under rocks, logs, and other debris.

Fish

Brook trout, Salvelinus fontinalis (ST): A permanent resident on the installation.

\section{INVERTEBRATES}

Hebard's noctuid moth, Erythroecia hebardi (C2) This species is recorded from the Lake HopatcongJohnsonburg area.

Mitchell's satyr butterfly, Meonympha mitchelli mitchelli (C2) This butterfly inhabits calcareous fens or lime sedge habitats in New Jersey. It may be extirpated. This species is recorded from the Dover-Lake Hopatcong area.

\section{Endangered Species Summary}

The bald eagle is an irregular visitor and the only known federally listed species found on the arsenal. Peregrine falcons may occur as rare migrants. Several state listed birds are known to occur on the installation. Resident species include the barred owl and the great blue heron. The goshawk is found in the winter. Known migrants include the American bittern, northem harrier, cliff swallow, osprey, pied-billed grebe, and savannah and vesper sparrows. Irregular visitors include the Cooper's and red-shouldered hawks and the upland sandpiper. Resident reptiles include the wood and bog turtles as well as the timber rattlesnake. The brook trout is found in waters of the installation. Possible nesting bird species include the grasshopper sparrow, short-eared owl, sedge wren, and the bobolink. The red-headed woodpecker, black rail, and yellow-crowned night heron may be seen as transients. The state listed longtail, blue-spotted, and Tremblay's salamanders may occur on the installation. 
Main Counties: Dinwiddle, Nottoway, and Brunswick

Surrounding Counties: Amelia, Prince Edward, Lunenburg, Mecklenburg, Greensville, Sussex, Prince George, Chesterfield

\section{VERTEBRATES}

Birds

Henslow's sparrow, Ammodramous henslowii (RSE): Found in low wetlands covered with brushes and sedges and sometimes in clearings, this bird historically bred in eastern Virginia. Its occurrence on the installation is possible.

Northern harrier, Circus cyaneus (RSE): Historically recorded as an uncommon migrant, this species may be seen on the installation.

American peregrine falcon, Falco peregrinus anatum (FE, SE): An uncommon migrant throughout the state, the falcon may be seen as a transient on the installation.

Migrant loggerhead shrike, Lanius ludovicianus migrans (C2, SE): The shrike may be found on the installation. Potential breeding sites have been identified in Brunswick and Dinwiddle Counties.

Bachman's warbler, Vermivora bachmanii (FE, SE): Considered the rarest warbler in North America, this bird historically was reported in Virginia. It may have occurred only as a migrant.

\section{INVERTEBRATES}

\section{Mollusks}

Dwarf wedge mussel, Alasmidonta heterodon (FE, SE): The Nottoway River within the bounds of Fort Pickett may provide habitat for this mussel. This species was listed on March 14, 1990. It has recently been found in the Nottoway River upstream of the installation.

\section{Endangered Species Summary}

Although no listed species are known to occur on Fort Pickett, the peregrine falcon may be seen as a transient. The loggerhead shrike may breed in the area. The northem harrier and the Henslow's sparrow may be seen as transients on the installation. The dwarf wedge mussel should be looked for in the Nottoway River adjacent to the installation. 


\section{RADFORD AAP AMC 6,901 Acres Virginia}

Main Counties: Montgomery, Pulaski

Surrounding Counties: Bland, Carroll, Craig, Floyd, Franklin, Giles, Roanoke, Wythe

\section{VERTEBRATES}

\section{Birds}

Northern harrier, Circus cyaneus (RSE): Historically recorded as an uncommon migrant, this species may be seen as a transient on the installation.

American peregrine falcon, Falco peregrinus anatum (FE, SE): This subspecies historically nested on cliffs on the New River. Mountain breeding populations are being reestablished. The falcon may be seen as a transient on the installation.

Migrant loggerhead shrike, Lanius ludovicianus migrans (C2, SE): The breeding range of this subspecies is within the area of the installation. Wintering birds also have been recorded in the vicinity.

Yellow-crowned night heron, Nycticorax violaceus (RST): This bird was recorded nesting around Radford in 1970. Usually found in marsh areas, its occurrence on the installation is possible.

Appalachian Bewick's wren, Thryomanes bewickii altus (C1): Historically recorded to breed in the mountainous areas of Montgomery County, this species may be seen as a transient on the installation.

Bachman's warbler, Vermivora bachmanii (FE, SE): Considered the rarest warbler in North America, this bird was historically reported in Virginia. It may occur as a migrant on the installation.

\section{Mammals}

Eastern cougar, Felis concolor couguar (FE): Historically found throughout the state, the continued presence of this species is unconfirmed.

Indiana bat, Myotis sodalis (FE, SE): Known from Nellie's Hole, Montgomery County, the bat may be seen as a transient along riparian areas of the installation.

\section{Amphibians}

Hellbender, Cryptobranchus alleganiensis (C2): The hellbender may be found in the New River. It has been reported in the vicinity of the installation.

Mudpuppy, Necturus maculosus maculosus (C2): Known from the New River, this species may be found in waters around the installation. 


\section{Fish}

Finescale saddled darter, Etheostoma osburni (C2): Known from the New River, this species may be found in waters around the installation.

Kanawha minnow, Phenocobius teretulus (C2): Collected in the New River, the minnow may occur in waters around the installation.

\section{INVERTEBRATES}

Virginia fringed mountain snail, Polygyriscus virginianus (FE, SE): This species may be found in talus and on bluffs along the New River.

\section{Endangered Species Summary}

The Virginia fringed mountain snail may be found in talus and on bluffs along the New River. The peregrine falcon may be a transient on the installation. The Bachman's warbler historically occurred in the area, and the Appalachian Bewick's wren may nest on or around the installation. Other federally listed species which may occur on the installation include the eastern cougar and the Indiana bat. Category species which may be found in the New River drainage include the hellbender, mudpuppy, kanawha darter and finescale darter. Other nesting birds of concern that may occur include the loggerhead shrike and the yellow-crowned night heron. The northern harrier may be seen as a transient. 
Main Counties: Portage, Trumbull

Surrounding Counties: Ashtabula, Geauga, Mahoning, Stark, Summit

\section{VERTEBRATES}

Birds

American bittern, Botaurus lentiginosus (SE): These bitterns have been sighted in Geauga, Portage, Summit, and Trumbull Counties since 1980. This may indicate a breeding population in the area.

Northern harrier, Circus cyaneus (SE): Summering harriers have been observed in Ashtabula and Trumbull Counties since 1980. They may be seen on the installation.

American peregrine falcon, Falco peregrinus anatum (FE, SE): This subspecies migrates through Ohio and since 1988, one pair has nested in Toledo. A rare occurrence on the installation is possible.

Arctic peregrine falcon, Falco peregrinus tundrius (FT, SE): This subspecies migrates through Ohio. A rare occurrence on the installation is possible.

King rail, Rallus elegans (SE): Records from the 1960s indicate these rails nested in Youngstown (about $25 \mathrm{~km} \mathrm{SE}$ ) and Geauga County. They may be found in marsh areas around the installation.

Northern waterthrush, Seiurus noveboracensis (SE): Since 1980, the thrush has summered in Portage County. These birds are found along streams, ponds, or wooded swamps. Their occurrence in areas around the installation is possible.

Bewick's wren, Thryomanes bewickii (SE): Although this wren historically nested in Portage County, few recent sightings have been recorded in Ohio.

Bam owl, Tyto alba (SE): Found throughout Ohio, the owl nests and roosts in tree cavities, barns, and abandoned buildings. Its occurrence on the installation is possible.

\section{Mammals}

Indiana bat, Myotis sodalis (FE, SE): This species may be found foraging in riparian areas of the installation. It is listed as possibly occurring in the main and surrounding counties.

\section{Reptiles}

Eastern massasauga, Sistrurus catenatus catenatus (C2): Historically, the massasauga was found within Stark and Trumbull Counties. 


\section{Fish}

Mountain brook lamprey, Ichthyomyzon greeleyi (SE): This species was collected in the West Branch of the Mahoning River. Streams originating on the installation may affect this area.

\section{INVERTEBRATES}

\section{Mollusks}

Eastern pondmussel, Ligumia nastua (SE): This species is found in waters around the installation.

\section{Endangered Species Summary}

No federally listed species are known to occur on the installation. The Indiana bat and the Peregrine falcon may occur as migrants. The eastern massasuaga, a category species, was historically found in the area. State listed species known from areas around the installation include the mountain brook lamprey and the eastern pondmussel. Other possible state listed birds that may be found include the American bittern, northern harrier, king rail, northern waterthrush, Bewick's wren, and barn owl. 


\section{REDSTONE ARSENAL}

AMC

3,800 Acres

Alabama

Main County: Madison

Surrounding Counties: Jackson, Limestone, Marshall, Morgan, AL; Franklin, Lincoln, TN

\section{VERTEBRATES}

\section{Birds}

Piping plover, Charadrius melodus (FT): This bird is found as a rare migrant throughout Alabama and may occur in Limestone County. Two birds were recorded on the Wheeler Wildlife Refuge in 1973. The refuge is across the Tennessee River from the installation. Occurrence on the shores of lakes on the installation is possible.

American peregrine falcon, Falco peregrinus anatum (FT, ST): The peregrine is a transient species in Alabama and migrates mainly along the Gulf Coast. Its occurrence on the installation is possible.

Arctic peregrine falcon, Falco peregrinus tundrius (FT, ST): The peregrine is a transient species in Alabama and migrates mainly along the Gulf Coast. Occurrence on the installation is unlikely but possible.

Southern bald eagle, Haliaeetus leucocephalus leucocephalus (FE, SE): Eagles have been sighted on the installation and two or three individuals have been recorded to winter at Wheeler National Wildlife Refuge.

Wood stork, Mycteria americana (FE, SE): Historical records listed stork occurrences for the Wheeler National Wildlife Refuge. Since storks can travel up to $128 \mathrm{~km}$ to feed, their occurrence on this installation is possible. The birds will forage in shallow ponds, on the shores of deeper fresh water, or other areas where there are high fish concentrations.

Appalachian Bewick's wren, Thryomanes bewickii altus (C1, ST): A rare migrant in the state of Alabama, sighting the wren on the installation is possible.

Bachman's warbler, Vermivora bachmani (FE, SE): This species was once a rare spring transient in central and northern Alabama. The bird has not been seen in the mountain region of Alabama since the late 1950s and is thought to be extinct.

\section{Reptiles}

American alligator, Alligator mississippiensis (FTSA): Populations have been reintroduced and have survived in the Wheeler National Wildlife Refuge.

\section{Mammals}

Red wolf, Canus rufus gregoryi (FE): Although this species is extirpated in Alabama, the installation is within its historic range. 
Florida panther, Felis concolor coryi (FE, SE): Although this species is probably extirpated in Alabama, the installation is within its historic range. Wild populations still exist, making the occurrence of this species possible.

Gray bat, Myotis grisescens (FE, SE): Known to use caves near the installation, the bats will also forage in riparian and other open water areas. Records also list the bats as occurring in surrounding counties.

Indiana bat, Myotis sodalis (FE, SE): This species may be found in Madison County as well as surrounding counties. It is known to occur in Jackson County. The bats may be found foraging in riparian areas.

Fish

Slackwater darter, Etheostoma boschungi (FE, ST): This darter is known in the Flint River drainages in Madison County. Although intense sampling has failed to find it in nearby drainages (e.g., Indian Creek), stretches of the Flint River are less than $25 \mathrm{~km}$ from the installation.

Tuscumbia darter, Etheostoma tuscumbia (C2): This species has been recorded in Indian Spring, which is less than $16 \mathrm{~km}$ from the installation.

\section{INVERTEBRATES}

\section{Mollusks}

Fanshell, Cyprogenia stegaria (irrorata) (C2): Historically this species was found in the Tennessee River. It was recorded in the Wheeler Reservoir and Guntersville Dam tailwaters in the early 1960 s.

Dromedary mussel, Dromus dromas (FE): Considered a "main channel" species, the subspecies caparatus was once collected in Limestone Creek, Mooresville. This location is less than $16 \mathrm{~km}$ from the installation. Modifications and impoundments in the river may make this species rare in this location.

Oyster mussel, Epioblasma capsaeformis (C2): This species was once collected in Limestone Creek, Mooresville, Limestone County, which is less than $16 \mathrm{~km}$ from the installation. This mussel is generally a stream species. This species may not be found in the area now because of modifications in the river system.

Tan riffleshell, Epioblasma walkeri (FE): This mollusk is listed as possibly occurring in Madison and Limestone Counties. Historical records show this species was collected in Limestone Creek in Mooresville, Limestone County and the Flint River and Hurricane Creek in Gurley, Madison County. These areas are less than 16 and $25 \mathrm{~km}$, respectively, from the installation.

Fine-rayed pigtoe, Fusconaia cunelous (FE): This mussel is known to occur in Jackson County. Historical records indicate this species was found in the Flint River and Hurricane Creek. These tributaries are less than $25 \mathrm{~km}$ from the installation. Another locale where this species has been found is Limestone Creek. This location is less than $16 \mathrm{~km}$ from the installation. The big river subspecies appressa has been found in the lower reaches of both Limestone Creek and the Flint River.

Shiny pigtoe, Fusconaia cor (edgarina) (FE): A species found throughout the Tennessee River, it is known to occur in Jackson County and in Limestone County. Historically, it was recorded in the Flint River at Gurley, Madison County, which is less than $25 \mathrm{~km}$ from the installation. 
Pink mucket pearly mussel, Lampsilis abrupta (=orbiculata) (FE): Known in Jackson, Madison, and Marshall Counties, and possibly Limestone County, this species has been found in various areas of the Tennessee River. Historical accounts show that it was once collected in Limestone Creek, Mooresville, Limestone County. This location is less than $16 \mathrm{~km}$ from the installation.

Birdwing pearly mussel, Lemiox rimosus(Conradilla caelata) (FE): This species has not been found near the installation, however, historical records show it was once collected in the Flint River.

Slabside pearly mussel, Lexingtonia dollabolloides (C2): This mollusk was recorded in Limestone Creek. This location is less than $16 \mathrm{~km}$ from the installation. This species also has been collected in the Flint River at Gurley and New Hope; both locations are less than $25 \mathrm{~km}$ from the installation.

Ring pink, Obovaria retusa (FPE): This is a large river species once collected throughout the Tennessee River.

Orange-foot pimpleback, Plethobasus cooperianus (FE): Possibly found in Madison County, this species was once found in Limestone Creek. This location is less than $16 \mathrm{~km}$ from the installation. Currently it is also known to occur in Marshall County.

Tennessee clubshell, Pleurobema oviforme (C2): This species was once collected in the Flint River at Gurley. Its subspecies holstonese was recorded in Limestone Creek (less than $16 \mathrm{~km}$ from the installation) and Hurricane Creek (less than $25 \mathrm{~km}$ from the installation). The clubshell may be extirpated from this area because of modifications and pollution in the river system.

Rough pigtoe, Pleurobema plenum (FE): Regarded as a "main river species," this mussel is known in Marshall County. It is listed as possibly occurring in Madison and Morgan Counties in tributaries around the installation.

Pale lilliput pearly mussel, Toxoplasma cylindrella $(\mathrm{FE})$ : Historical records show this species was found in the Flint River and in Indian Creek, Madison County. Indian Creek flows through the installation. Populations are presently known to occur in Jackson County.

\section{Other}

Alabama cave shrimp, Palaemonias alabamae $(\mathrm{FE})$ : One of the remaining populations of this species is found in Bobcat Cave on the Arsenal. Agreements have been signed between the Army and the U. S. Fish and Wildlife Service to preserve this species' habitat.

\section{Endangered Species Summary}

The Alabama cave shrimp is known to occur in Bobcat Cave on the installation. The bald eagle, and the gray bat are the only two species likely to be found and affected by installation activities. 
FORT RUCKER TRADOC 64,379 Acres Alabama

Main Counties: Dale, Coffee

Surrounding Counties: Barbour, Covington, Crenshaw, Geneva, Henry, Houston, Pike

\section{VERTEBRATES}

\section{Birds}

American ivory-billed woodpecker, Campephilus principalis principalis (FE): Historically known from the southeast, this bird was last sighted in Alabama in 1907.

American peregrine falcon, Falco peregrinus anatum (FT, ST): A local transient species in Alabama migrating along the Gulf Coast, its occurrence on the installation is possible.

Arctic peregrine falcon, Falco peregrinus tundrius (FT, ST): A local transient species in Alabama migrating along the Gulf Coast, its occurrence on the installation is possible.

Southern bald eagle, Haliaeetus leucocephalus leucocephalus (FE, SE): Known occurrences are listed in Barbour and Henry Counties. Because the birds may range widely to forage, an occurrence on or near the installation is possible.

Wood stork, Mycteria americana (FE, SE): This species is known to occur in Barbour County. Possible occurrences are listed in Covington, Henry and Houston Counties. Since storks can travel up to $128 \mathrm{~km}$ to feed, its occurrence on this installation is possible. The birds will forage in shallow ponds, on the shores of deeper fresh water, or other areas where there are high concentrations of fish. When populations are high in Florida, the wood storks are more likely to appear in Alabama, where they may disperse after the breeding season.

Red-cockaded woodpecker, Picoides borealis (FE, SE): Historically, this bird was found throughout the state. It could occur within the installation if suitable pine stands were available.

Appalachian Bewick's wren, Thryomanes bewickii altus (C1, ST) This bird is a rare migrant in Alabama. Sighting on the installation is possible but unlikely.

Bachman's warbler, Vermivora bachmani (FE, SE): This species was once a rare summer resident in southern Alabama. The bird has not been seen in the mountain region of Alabama since the late 1950s.

\section{Reptiles}

Eastern indigo snake, Drymarchon corais couperi (FT, SE): Although this species has not been found as a native in Alabama since 1954, the installation is within its historical range. Attempts to restock have also been made in Covington County. Habitat availability and historical records indicate it could occur in Covington and Geneva counties.

Gopher tortoise, Gopherus polyphemus (C2, ST): The western population of this species, not within the range of the installation, is considered threatened. The historic range of the eastern population includes the installation. 


\section{Mammals}

Red wolf, Canus rufus gregoryi (FE): Although this species is extirpated in Alabama, the installation is within its historic range.

Florida panther, Felis concolor coryi (FE, SE): Although this species is probably extirpated in Alabama, the installation is within its historic range. Wild populations still exist, making the occurrence of this species possible.

Indiana bat, Myotis sodalis (FE, SE) : This species may occur in Coffee and Dale counties. It is also listed as possibly occurring in all surrounding counties except Covington. If suitable habitat (riparian areas) is available, this species may be found foraging within the installation.

\section{INVERTEBRATES}

\section{Mollusks}

Southem sandshell, Lampsilis australis (C2): Historical records indicate this species was collected less than 5 miles from the installation (10). It was also found at the East Fork of the Choctawhatchee River, at Midland City, less than 10 miles from the installation.

Southern kidneyshell, Ptychobranchus (Lampsilis) jonesi (C2): Historical records indicate this species was taken from the West Fork Choctawhatchee River, 7 miles southeast of Ozark, and in the Choctawhatchee River, one mile north of Newton. Both locations are in Dale County and less than $9 \mathrm{~km}$ from the installation.

Choctaw bean, Villosa choctawensis (C2): This species was collected in the Choctawhatchee River at Waterford. This is less than $4 \mathrm{~km}$ from the installation. Modifications in the river system may make the occurrence of this species rare.

\section{Endangered Species Summary}

There are no records of endangered species on the installation, although habitat may be available for redcockaded woodpeckers and gopher tortoises. Historical records indicate several additional species may have been present in the past. 
CAMP SANTIAGO

NGB

11,379 Acres Puerto Rico

Main Municipality: Salinas

Surrounding Municipality: Guamo

\section{VERTEBRATES}

\section{Birds}

Yellow-shouldered blackbird, Agelaius xanthomus (FE): Formerly common along the coast throughout the island, this species occurs within a $9.4-\mathrm{km}$ radius of the installation.

Red siskin, Carduelis cucullata (No federal rating): This Venezuelan species has become established in southern Puerto Rico. It may be found nesting in areas of Camp Santiago.

Piping plover, Charadrius melodus (FT): A rare winter visitor in Puerto Rico, this species may be seen as a transient on the installation. It has been seen within $9.4 \mathrm{~km}$ of the installation.

Puerto Rican plain pigeon, Columba inornata wetmore (FE): This species is known only to survive in forested ravines and bamboo clumps surrounding Lake Cidra. Lake Cidra is less than $9.4 \mathrm{~km}$ from the installation.

American peregrine falcon, Falco peregrinus anatum (FE): Falcons are regular but uncommon to rare winter visitors. They usually are found on off-shore cays and rocks and water bodies containing many shorebirds or waterfowl, but are sometimes seen inland. Falcons are found from April to October, being more common during migration.

Arctic peregrine falcon, Falco peregrinus tundrius (FT): Falcons are regular but uncommon to rare winter visitors. They usually are found on off-shore cays and rocks and water bodies containing many shorebirds or waterfowl, but are sometimes seen inland. Falcons are found from April to October, being more common during migration.

Brown pelican, Pelicanus occidentalis (FE, SE): A nesting species on the island, the pelican may be seen as a transient on the installation, especially during the winter when populations are supplemented with migrants.

Roseate tern, Sterna dougallii (FT): A breeding resident seen mostly from April to September, this species is known to occur within a $9.4-\mathrm{km}$ radius of the installation.

\section{Reptiles}

Puerto Rican Boa, Epicrates inornatus (FE): This species has been collected and potential habitat occurs in areas north of the installation.

\section{Amphibians}

Golden coqui, Eleutherodactylus jasperi (FE): All specimens to date have been collected from a small semicircular area of $3.8-\mathrm{km}$ radius south of Cayey, generally at elevations above 700 meters. Areas of critical habitat are less than $3.1 \mathrm{~km}$ north of the installation. 
Puerto Rican crested toad, Peltophryne lemur (FT): Native to the island, this species historically was collected near Coamo, a town near the installation.

\section{Endangered Species Summary}

The yellow-shouldered blackbird may be seen on the installation. Breeding species that may be seen as transients on the installation include the brown pelican and the roseate tern. Species that occur near the installation include the Puerto Rican plain \& pigeon, the Puerto Rican boa, the golden coqui, and the Puerto Rican crested toad. Winter migrants that may be seen include the peregrine falcon and the piping plover.

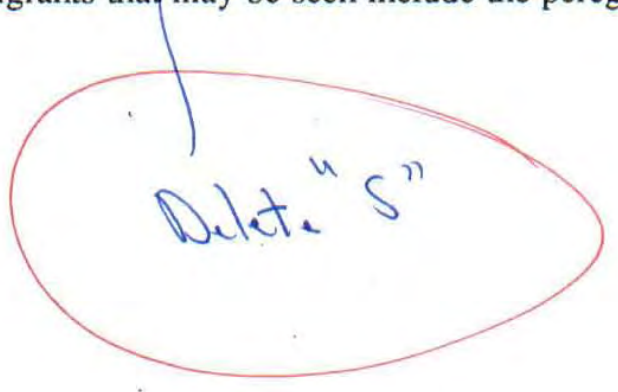




\section{SAVANNA AD AMC 13,000 Acres Illinois}

Main Counties: Carroll, JoDaviess

Edge County: Jackson, IA

Surrounding Counties: Stephenson, IL; Clinton, Dubuque, IA; Grant, LaFayette, WI

\section{VERTEBRATES}

\section{Birds}

Cooper's hawk, Accipiter cooperi (SE): An uncommon migrant and winter resident as well as a rare summer resident, this hawk was recorded on the installation in June 1990. There is strong evidence that it breeds here.

Sharp-shinned hawk, Accipiter striatus (SE): A common migrant, an uncommon winter resident, and a very rare summer resident, this bird was recorded in Carroll and Whiteside Counties in January, 1986. Its occurrence on the installation is possible.

Short-eared owl, Asio flammeus (SE): An uncommon migrant and winter resident and a rare summer resident, this species was recorded in Carroll County in 1980. Its occurrence on the installation in marsh or field areas is possible.

Long-eared owl, Asio otus (SE): An uncommon migrant and winter resident and a rare summer resident, this species roosts in conifer groves by day. It may be seen on the installation as a migrant.

Upland sandpiper, Bartramia longicauda (SE): An uncommon migrant and summer resident throughout Illinois, the sandpiper was found on the installation in June 1990. It is also known to breed here.

American bittem, Botaurus lentiginosus (SE): An uncommon migrant and rare summer and winter resident, historical records indicate the bird inhabited the area. Their occurrence on the installation is possible.

Red-shouldered hawk, Buteo lineatus (SE): An uncommon migrant, summer and winter resident in southern Illinois, this bird was observed on the installation during the breeding season in 1989.

Swainson's hawk, Buteo swainsoni (3C, SE): Recorded in the spring of 1986 in Whiteside County, this species is a rare migrant and local summer resident in northern Illinois. Its occurrence as a migrant on the installation is possible.

Great egret, Casmerodius albus (SE): The egret is known to occur in nesting rookeries on the installation and in other areas of JoDaviess County.

Veery, Catharus fuscescens (ST): A common migrant, this bird may be seen on the installation. Breeding habitat is not available.

Brown creeper, Certhia americana (ST): A common migrant and winter resident and an occasional summer resident, this species was found nesting on the installation in 1990. 
Black tern, Chlidonias niger (SE): A common migrant and a common summer resident in northem Illinois and a rare summer resident in the central part of the state, this bird uses the Mississippi River valleys for migration routes. Its occurrence on the installation is possible, although it is not likely to breed there.

Northern harrier, Circus cyaneus (SE): A common migrant and uncommon winter and rare summer resident throughout the state. The harrier may be seen on the installation.

Little blue heron, Egretta caerula (SE): An uncommon migrant breeding locally in the southern part of the state, its occurrence on the installation as a postbreeding wanderer is possible.

American peregrine falcon, Falco peregrinus anatum (FE, SE): An uncommon migrant and rare winter resident, peregrines are being reintroduced to the state. Their occurrence on the installation is possible, although unlikely. Suitable breeding habitat may occur along bluffs of the Mississippi River.

Arctic peregrine falcon, Falco peregrinus tundrius (FT, SE): An uncommon migrant and rare winter resident, the occurrence of these peregrines on the installation is possible, although unlikely.

Northem bald eagle, Haliaeetus leucocephalus alascanus (FE, SE): The eagle is known to nest and winter on the installation.

Least bittern, Ixobrychus exilis (SE): An uncommon migrant and summer resident, historically, the bittern nested in northern Carroll County. Occurrence on the installation is possible.

Migrant loggerhead shrike, Lanius ludovicianus migrans (C2, ST): An occasional summer and winter resident, the shrike is listed as occurring in Carroll County. Shrikes were also recorded in Whiteside County in the fall of 1981. The occurrence of these birds on the installation is possible.

Black-crowned night heron, Nycticorax nycticorax (SE): A fairly common migrant and an uncommon summer and rare winter resident, historical records indicate this bird was found in Carroll County. It may be found in marsh areas of the installation, most likely while it is foraging.

Osprey, Pandion haliaeetus (SE): Although an uncommon migrant, eight birds were recorded at Savanna in September 1985. Occurrence on the installation is possible.

Double-crested cormorant, Phalacrocorax auritus (SE): An uncommon migrant along the Mississippi River, a cormorant colony is at Thompson in Carroll County. Occurrence of these birds on the installation is possible.

Barn owl, Tyto alba (SE): An occasional resident throughout the state, this species roosts in man-made structures. It was found adjacent to the installation in 1986 and 1987.

Yellow-headed blackbird, Xanthocephalus xanthocephalus (SE): A locally uncommon summer resident, the blackbird is listed as occurring in Carroll County.

\section{Reptiles}

Dusty hognose snake, Heterodon nasicus gloydi (ST): This snake is listed as occurring in Carroll County. Its occurrence on the installation is likely.

Eastern massasauga, Sistrurus catenatus catenatus (C2): This snake is listed as occurring in JoDaviess County, and its occurrence on the installation is possible. 


\section{Mammals}

White-tailed jackrabbit, Lepus townsendii (SE): This species has been known to occur on the installation, although a 1990 survey failed to find the rabbit. This is the only known population of this species in the state. A s in 990 dic

River otter, Lutra canadensis (ST): This species is known to occur on the installation.

Bobcat, Lynx rufus (ST): This species is listed as occurring in Carroll and JoDaviess Counties, and may be found on the installation.

Indiana bat, Myotis sodalis (FE, SE): The bat is listed as occurring in JoDaviess County. Statewide in distribution, the bat may be found in riparian areas with mature trees. It forages for insects by flying under tree canopies, and may be found within these areas on the installation.

Fish

Lake sturgeon, Acipenser fulvescens (ST): A rare find in the state of Illinois, this fish may be seen in the Mississippi River. Fifteen sturgeon were caught in the vicinity of the installation in 1989.

Pallid shiner (chub), Notropis (=Hybopsis) amnis (SE): Collected in 1983, $6.4 \mathrm{~km}$ north of Blackhawk, this species may be found in waters around the installation.

\section{INVERTEBRATES}

\section{Mollusks}

Spectaclecase, Cumberlandia monodonta (C2, SE): Rare and local, this species was historically collected on the Mississippi River.

Elephant-ear, Elliptio crassidens (ST): This mollusk was historically collected in the Mississippi River less than $8 \mathrm{~km}$ from the installation.

Snuff box, Epioblasma triquetra (SE): Found in the Mississippi River, this species may occur in waters around the installation.

Higgins eye, Lampsilis higginsi (FE, SE): Found in the Mississippi River and larger tributaries, this species was historically collected in waters around the installation. It is still recorded in JoDaviess County.

Scaleshell, Leptodea leptodon (C2): This species was historically recorded at Savanna, in Carroll County. Its occurrence in waters around the installation is possible.

Sheepnose, Plethobasus cyphyus (ST): Historically collected from the Mississippi River, the occurrence of this species in waters around the installation is possible.

Rainbow, Villosa iris (SE): This species has been collected in the upper Mississippi River. Its occurrence in waters around the installation is possible. 


\section{Endangered Species Summary}

The bald eagle is known to use areas of the installation for breeding and wintering. The white-tailed jackrabbit and river otter are state endangered and threatened species known to occur on the installation. State and federally listed mollusks may be found in the Mississippi River around the installation. Several other state listed species, including herons, egrets, river otters, and fish may occur in marsh areas of the installation. 
SENECA AD AMC 16,350 Acres New York

Main County: Seneca

Surrounding Counties: Cayaga, Ontario, Schuyler, Tompkins, Wayne, Yates

\section{VERTEBRATES}

\section{Birds}

Golden eagle, Aquila chrysaetos (SE): A rare to uncommon migrant, the occurrence of this species on the installation is possible.

Red-shouldered hawk, Buteo lineatus (ST): A common to locally abundant migrant, this bird may be seen on the installation. Its breeding range is also within the area.

Northern harrier, Circus cyaneus (ST): A common to very abundant migrant, especially in the spring along Lake Ontario, this species may be seen on the installation. It may also breed in the area.

American peregrine falcon, Falco peregrinus anatum (FE, SE): This species is a rare migrant through the area, although reintroductions have improved the likelihood that a falcon may be encountered.

Arctic peregrine falcon, Falco peregrinus tundrius(FT, SE): This species is a rare migrant throughout the area.

Northern bald eagle, Haliaeetus leucocephalus alascanus (FE, SE): Known to breed in Seneca County, this species may be seen as a transient or migrant on the installation.

Osprey, Pandion haliaetus (ST): A fairly common to common migrant along Lake Ontario, the osprey may be seen around riparian areas or Seneca Lake.

Common tern, Sterna hirundo (ST): A locally abundant breeder along the north edge of Cayuga Lake it may be seen around riparian areas of the installation during migration.

\section{Reptiles}

Bog turtle, Clemmys muhlenbergi $(\mathrm{C} 2, \mathrm{SE})$ : The range of this turtle includes the installation, making its occurrence possible.

Timber rattlesnake, Crotalus horridus (ST): The installation is at the northern part of this snake's range. Its occurrence is possible.

Massasauga, Sistrurus catenatus catenatus (SE): The installation is at the southeastern edge of this snake's range. Its occurrence is possible. 


\section{Mammals}

Mountain lion, Felis concolor cougari (FE, SE): Although this species has probably been extirpated from New York, the lion historically occurred in this area.

Indiana bat, Myotis sodalis (FE, SE): This species may occur in Seneca and all the surrounding counties. Its occurrence as a transient in riparian areas of the installation is possible.

\section{Endangered Species Summary}

No federally listed species are known to occur on the installation. The bald eagle is known to nest in the area and the peregrine falcon may be seen as a migrant. State listed birds that may migrate include the golden eagle, red-shouldered hawk, northern harrier, osprey, and common tern. State listed reptiles that range within areas of the installation include the bog turtle, timber rattlesnake, and the massasauga. The Indiana bat may be seen as a transient on the installation. 
CAMP SHELBY NGB $\quad 136,000$ Acres $\quad$ Mississippi

Main Counties: Forrest, Perry

Surrounding Counties: Covington, Jones, Lamar, Pearl River, Stone

Birds

Bachman's sparrow, Aimophila aestivalis (C2): Found in Perry County, these sparrows will inhabit open pastures, thick grasses with low trees, and open woodlands. Occurrence on the installation is possible.

American peregrine falcon, Falco peregrinus anatum (FE, SE): These birds migrate along the Atlantic and Gulf coasts. This species may occur within the area as a migrant.

Red-cockaded woodpecker, Picoides borealis (FE, SE): One colony was known to exist on the installation in recent years. No birds were observed during a 1990 survey of the camp. The woodpeckers require mature pine forests (greater than 60 or 70 years old) for nesting.

\section{Reptiles}

American alligator, Alligator mississipiensis (FTSA, SE): This species is listed as occurring in Perry County. Since alligators inhabit swamps and rivers, their occurrence around the installation is possible.

Eastern indigo snake, Drymarchon corais couperi (FT, SE): A commensal species with the Gopher tortoise, this snake could be found wherever the tortoise is found. Historically the snake occurred within the area of the installation.

Gopher tortoise, Gopherus polyphemus (FT, SE): The tortoise is found in the DeSoto National Forest and within the camp's boundaries.

Black pine snake, Pituophis melanoleucus lodgini (C2, SE): This snake is listed in Forrest and Perry Counties and is present on the installation.

\section{Mammals}

Red wolf, Canus rufus gregoryi (FE): Although extirpated in Mississippi, the installation is within its historic range. Remaining populations are in captivity.

Florida panther, Felis concolor coryi (FE, SE): Historically this species inhabited the area. Although wild populations still exist, they are rare and panthers are unlikely to be found on the installation.

\section{Endangered Species Summary}

The red-cockaded woodpecker, gopher tortoise, and indigo snake are the only federally listed species known or likely to exist within the boundaries of Camp Shelby. The state listed black pine snake is also found on the installation. Other species may possibly occur, generally as transients. 


\section{FORT STEWART FORSCOM 279,270 Acres Georgia}

Main Counties: Bryan, Evans, Liberty, Long, Tattnall

Edge County: Chatham

Surrounding Counties: Appling, Bullock, Candler, Effingham, McIntosh, Toombs, Wayne

\section{VERTEBRATES}

\section{Birds}

American ivory-billed woodpecker, Campephilus principalis principalis (FE, SE): This bird historically ranged through coastal and southern Georgia. Last reports were recorded from Florida in the 1950s and Texas in 1967. It is thought to be extinct.

Piping plover, Charadrius melodus (FT): Known in Chatham, Liberty, and McIntosh Counties, the plovers winter along coastal areas. The occurrence of these birds on or near Hunter Army Airfield is possible.

Kirtland's warbler, Dendroica kirtlandii (FE, SE): The warbler migrates along the coast and may be seen on the installation.

American peregrine falcon, Falco peregrinus anatum (FE, SE): This falcon is a migrant through Georgia, and its occurrence on the installation is possible.

Arctic peregrine falcon, Falco peregrinus tundrius (FT): This falcon is a migrant through Georgia, and its occurrence on the installation is possible.

Southern bald eagle, Haliaeetus leucocephalus leucocephalus (FE, SE): Historically, eagles bred in December on coastal islands of Georgia. Presently, these birds are transitory in Bryan and Liberty Counties and known from Chatham and McIntosh Counties, probably as winter residents. Eagles may travel several miles to forage, and the occurrence of these birds on the installation is likely. There is a hacking station on the Altamaha River in McIntosh County.

Wood stork, Mycteria americana (FE): Listed as foraging in Bryan and Liberty Counties, it is also known to occur in Chatham and McIntosh Counties, and may also be found in Effingham, Long, and Wayne Counties. Storks may travel up to $128 \mathrm{~km}$ between nesting and feeding areas. Receding water levels with high concentrations of fish are ideal foraging conditions. These birds may be found within or around the installation if such conditions exist.

Eastern brown pelican, Pelecanus occidentalis carolinensis(SE): Pelicans are found along the coast and may occasionally be found within the installation or Hunter Army Airfield.

Red-cockaded woodpecker, Picoides borealis (FE, SE): Nesting in Liberty and Bryan Counties, 189 colonies have been recorded on the installation.

Appalachian Bewick's wren, Thryomanes bewickii altus (C1): Historically, this bird was recorded in the Savannah area as a migrant. Occurrence on the installation is possible.

Bachman's warbler, Vermivora bachmanii (FE, SE): Historically recorded as breeding near Savannah, this bird is considered the rarest warbler of North America, and may be extinct. 


\section{Reptiles}

American alligator, Alligator mississippiensis (FTSA): The alligator is known to occur on the installation.

Loggerhead sea turtle, Caretta (FT): Known in Bryan, Chatham, Liberty, and McIntosh Counties, this species lays its eggs on beaches along the coast, but spends most of the rest of its life on the open ocean.

Eastern indigo snake, Drymarchon corais couperi (FT, ST): Known to occur in all main counties and may occur in Chatham and Toombs Counties. A commensal species with the Gopher tortoise, this snake could be found where ever the tortoise is found.

Gopher tortoise, Gopherus polyphemus (C2): The tortoise is known to occur on the installation.

Kemp's (Atlantic) ridley sea turtle, Lepidochelys kempii (FE, SE): This species is known to occur in Bryan and McIntosh Counties, and may possibly be seen in Chatham and Liberty Counties. Prefers shallow waters, and may be seen in waters around the installation.

\section{Mammals}

Red wolf, Canus rufus gregoryi (FE): Although this species is extirpated in Georgia, the installation is within its historic range.

Florida panther, Felis concolor coryi (FE): Although a very rare transient in Georgia, this species once was found throughout the state. Wild populations still exist, making the panther's occurrence on the installation possible.

Eastern cougar, Felis concolor cougari (FE, SE): Although a very rare transient in Georgia, this species was once found throughout the state. Wild populations still exist, making the cougar's occurrence on the installation possible.

Sherman's pocket gopher, Geomys pinetis fontanelus (3A, SE): The historical distribution of this species was probably less than $16 \mathrm{~km}$ from the installation. The present distribution is unknown.

West Indian manatee, Trichechus manatus (FE, SE): Known to occur in Chatham, Liberty, and McIntosh Counties, the manatees inhabit inter-coastal areas and may be seen along waterways near the installation.

\section{Fish}

Shortnose sturgeon, Acipenser brevirostrum (FE, SE): This species habitat is Atlantic seaboard rivers. The occurrence of this species in waters on and around the installation is likely.

\section{Endangered Species Summary}

The red-cockaded woodpecker, the gopher tortoise, and the alligator are federally listed species known to occur on the installation. The indigo snake is likely to be found in the area. The wood stork and bald eagle may be seen foraging on the installation. Peregrine falcon, Kirtland's warbler, and Bewick's wren may be observed during migration. The brown pelican and piping plover may be found in coastal areas, and manatees and sea turtles may be seen in waters near the installation or around Hunter Army Airfield. 
Main County: Virginia Beach

Surrounding Counties: Accomack; Chesapeake City, VA; Currituck, NC

\section{VERTEBRATES}

\section{Birds}

Henslow's sparrow, Ammodramous henslowii (RSE, S1): Reported from Virginia Beach, the sparrow may be seen on the installation.

Piping plover, Charadrius melodus (FT, ST): Although these birds breed on the Barrier Islands and rarely west of the Chesapeake Bay, they may be seen as transients on the installation.

Wilson's plover, Charadrius wilsoni (SE): The plover nests in Northhampton County along the Atlantic coast. It may be seen on the installation as a transient.

Northern harrier, Circus cyaneus (RSE): Historically recorded as an uncommon migrant, this species may be seen on the installation.

Sedge wren, Cistothorus platensis (RSE): An uncommon to common transient and winter resident along the Atlantic coast, the wren may be seen on the installation.

American peregrine falcon, Falco peregrinus anatum (FE, SE): The falcon migrates along the coast and may be seen on the installation. A coastal breeding population is being reestablished.

Arctic peregrine falcon, Falco peregrinus tundrius (FT, SE): The falcon migrates along the coast and may be seen on the installation.

Yellow-crowned night heron, Nycticorax violaceus (RST): An uncommon summer resident of the Coastal plain and rare in the winter, this species may be seen on the installation.

Eastern brown pelican, Pelecanus occidentalis (FE): The pelican is an occasional spring, summer, and fall visitor near the Atlantic Coast and at the mouth of the Chesapeake Bay. Its occurrence on the installation is likely.

Eastern least tern, Sterna antillarum antillarum (RST): The tern nests along the Atlantic coast and feeds in the Chesapeake Bay estuary. Former colonies were known from Cape Henry. Occurrence of this species on the installation is likely.

Gull-billed tem, Sterna nilotica (RST): The gull nests mainly on barrier islands along the Atlantic coast, and may be seen as a transient on the installation.

Bachman's warbler, Vermivora bachmanii (FE, SE): Considered the rarest warbler in North America, this bird was historically reported in Virginia. It may have occurred only as a migrant. 


\section{Reptiles}

Loggerhead sea turtle, Caretta caretta caretta (FT, ST): The most common sea turtle in Chesapeake Bay, the loggerhead nests along Virginia's shoreline. Occasionally, this includes Virginia Beach. The turtles are usually seen from May to October.

Green turtle, Chelonia mydas mydas (FT): Immatures less than $45 \mathrm{~kg}$ are considered uncommon summer visitors in the lower Chesapeake Bay. Their occurrence in waters around the installation is possible.

Eastern chicken turtle, Deirochelys reticularia reticularia (SE): A rare species reported from the adjacent Seashore State Park. This turtle is found in Cypress ponds.

Atlantic leatherback, Dermochelys coriacea (FE): An occasional summer visitor in the Chesapeake Bay region, this turtle is usually seen from May to October.

Kemp's (Atlantic) ridley, Lepidochelys kempii (FE, SE): Found along the Atlantic shoreline, this species is an occasional summer resident in coastal waters.

\section{Mammals}

Pungo mouse, Peromyscus leucopus easti (C2): Known from Virginia Beach, this species may be found in areas on or around the installation.

\section{Fish}

Shortnose sturgeon, Acipenser brevirostrum (FE, SE): Found in coastal waters along the Atlantic, this fish is a rare visitor in waters around the installation.

\section{Endangered Species Summary}

The piping plover and peregrine falcon may be seen as transients on the installation. The Bachman's warbler, another federally listed species, has historically been reported from the area, although it may be extinct. Brown pelicans may also be seen on the shore of the installation. Sea turtles, as well as the shortnose sturgeon may be seen on coastal waters of the installation. The loggerhead turtle may nest in the vicinity. The state listed chicken turtle may be seen on inland waters of the installation. The pungo mouse, various shorebirds and terns, as well as the sedge wren and the Henslow's sparrow are state listed species that may occur on the installation. 


\section{SUNNY POINT MILITARY TERMINAL MTMC 11,274 Acres North Carolina}

Main County: Brunswick

Edge County: New Hanover

Surrounding Counties: Columbus, Pender

\section{VERTEBRATES}

\section{Birds}

Bachman's sparrow, Aimophila aestivalis (C2): Found in open pinewoods and old fields, this species is listed as occurring in Brunswick County, most likely as a year-round resident. The sparrow generally inhabits open stands of longleaf pine where red-cockaded woodpeckers are found.

American ivory-billed woodpecker, Campephilus principalis principalis (FE): Although this species was formerly found throughout eastern South Carolina and southeastern North Carolina, its present distribution is unknown, and it is thought to be extinct.

Piping plover, Charadrius melodus (FE, ST): Known in Brunswick and Pender Counties, the plover also may be found in adjacent New Hanover County. There is an extensive shorebird foraging area--mud flats found along the northern portion of the Smith Island Estuaries (across the Cape Fear River from the installation). The plovers are probably found here.

Kirtland's warbler, Dendroica kirtlandii (FE, SE): This species was recorded on fall migration in Pender County. Since the birds migrate along the coast, its occurrence on the installation is possible.

American peregrine falcon, Falco peregrinus anatum (FE, SE): This species is an uncommon fall transient and rare winter resident along the coast. It has not been known to breed in the area.

Arctic peregrine falcon, Falco peregrinus tundrius (FT, SE): This species is an uncommon fall transient and rare winter resident along the coast, making its occurrence on the installation possible. It has not been known to breed in the area.

Southern bald eagle, Haliaeetus leucocephalus leucocephalus (FE, SE): Breeding is possible and habitat on the installation is suitable. In winter, the northem subspecies alascanus, which breeds from Alaska to Quebec, is found throughout the state.

Wood stork, Mycteria americana (FE): These birds are known to occur in Brunswick County, primarily as post-breeding visitors at Sunset Beach and Calabash. Since storks can travel up to $128 \mathrm{~km}$ to feed, its occurrence on this installation is possible. The birds will forage in shallow ponds, on the shores of deeper fresh water, or other areas where the concentrations of fish is high, such as areas of receding water levels.

Red-cockaded woodpecker, Picoides borealis (FE, SE): Colonies have been recorded on the installation.

Roseate tern, Sterna dougalli dougalli (FE, SE): A rare transient and occasional breeding species in North Carolina, this species may be seen on the installation as a migrant.

Bachman's warbler, Vermivora bachmainii (FE) This bird was once found throughout the southeast, including the area of the installation. Present distribution is unknown, and it is possible that the species is extinct. 


\section{Reptiles}

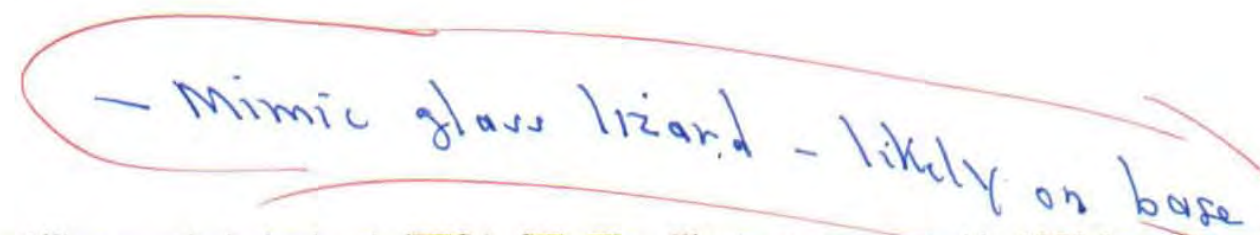

American alligator, Alligator mississippiensis (FTSA, ST): The alligator was reported in 1978 from Snow's Marsh and Walden Creek.

Loggerhead sea turtle, Caretta caretta (FT, SE): Known to occur in New Hanover, Brunswick, and Pender Counties, this species lays its eggs on beaches along the coast, but spends most of the rest of its life on the open ocean. It is fairly common along the Carolina coasts during the late April to mid-November nesting season.

Green turtle, Chelonia mydas (FE, ST): This species was formerly common along the coast in North Carolina. It does not nest in the area.

Leatherback turtle, Dermochelys coriacea (FE, SE): Although not common along the Carolina coast, there is one nesting record along the North Carolina coast in 1966. This species may be seen within waters around the installation.

Hawksbill turtle, Eretmochelys imbricata (FE, SE): Although not common along the Carolina coasts, the occurrence of this species is possible. It is not usually found in water over $20 \mathrm{~m}$ deep.

Kemp's (Atlantic) ridley sea turtle, Lepidochelys kempii (FE, SE): This species may be found in Brunswick County, although it is usually uncommon along the Carolina shores.

\section{Mammals}

Red wolf, Canis rufus gregoryi (FE, SE): Although this species is extirpated in North Carolina, the installation is within its historic range. Captive bred wolves have been reintroduced on the Alligator River National Wildlife Refuge in northeastern North Carolina.

Eastern cougar, Felis concolor cougari (FE, SE): Although this species is probably extirpated in North Carolina, the installation is within its historic range. Wild populations may still exist, making the occurrence of this species possible.

Rafinesque's big-eared bat, Plecotus rafinesquii (C2): An uncommon to rare species, this bat is found along coastal areas in dilapidated buildings, hollow trees, and behind loose bark. Its occurrence on the installation is possible.

West Indian (Florida) manatee, Trichechus manatus (FE, SE): The North Carolina coast is the northernmost part of the manatee's summer range. Its occurrence off the coast of the installation is possible.

\section{Amphibians}

Carolina gopher frog, Rana areolata capito (C2): This species was collected on the installation in 1978 and 1983. It also was found on the Carolina Beach Natural Area in 1979.

\section{Fish}

Short-nosed sturgeon, Acipenser brevirostrum (FE, SE): This species is found in the Cape Fear River. 


\section{INVERTEBRATES}

Magnificent ramshom (Cape Fear ramshorn), Planorbella (Halisoma) magnificum (C2, SE): Listed as occurring on the installation, this snail has been found in Greenfield Lake, Wilmington, usually under vegetation. Although it may no longer be present here, the snail was found in Orton Pond in 1986. This pond is adjacent to the terminal. The snail may also be found in larger ponds on the base.

Rare skipper, Problema bulenta (C2): Known from New Hanover and Brunswick Counties this butterfly occurs on the installation and is thought to be associated with freshwater marshes.

\section{Endangered Species Summary}

The piping plover and red-cockaded woodpecker are federally listed species known to occur on or near the installation. Possible transients include the bald eagle, roseate tern, wood stork, Kirtland's warbler, and peregrine falcons. Manatees and sea turtles may be found in waters near the installation. The magnificent ramshom is a state listed species on the installation. The Cooper's and sharp-shinned hawks may be transients. The Bachman's sparrow is generally found in pine stands with the red-cockaded woodpecker. Other species of concern known on the installation include the rare skipper, Carolina gopher frog, and Rafinesque's big eared bat. 


\section{U.S. MILITARY ACADEMY USMA 17,036 Acres New York}

Main County: Orange

Edge Counties: Putnam (across Hudson R) Ulster

Surrounding Counties: Dutchess, Rockland, Sullivan, NY; Sussex, Passaic, NJ

\section{VERTEBRATES}

Birds

Golden eagle, Aquila chrysaetos (SE): A very rare winter visitor, individuals have been observed migrating over the reservation in the fall. Two eagles overwintered at Stilwell Lake in 1980, feeding on deer carcasses.

Red-shouldered hawk, Buteo lineatus (ST): An uncommon resident, this bird may breed on the reservation.

Northem harrier, Circus cyaneus (ST): This species is known as a common fall migrant over the reservation.

American peregrine falcon, Falco peregrinus anatum (FE, SE): This species is a rare migrant through the area, although reintroductions have improved the likelihood that a falcon may be encountered.

Arctic peregrine falcon, Falco peregrinus tundrius (FT, SE): This species is a rare migrant through the area.

Northem bald eagle, Haliaeetus leucocephalus alascanus (FE, SE): A rare winter visitor, up to six eagles have wintered on Iona Island on the Hudson River. Other eagles may be seen migrating on the reservation in August and September.

Migrant loggerhead shrike, Lanius ludovicianus migrans (C2, SE): This bird is a rare migrant through the area, and the only habitat available is in the old fields along Smith Clove and Mineral Springs Roads and in the impact area.

Osprey, Pandion haliaetus (ST): A regular migrant on the reservation, feeding and resting individuals and pairs have been observed at Round Pond and Wilkens Pond in the spring and fall.

Interior least tem, Sterna antillarum antillarum (SE): A rare wanderer, this bird may fly up the Hudson River.

Common tern, Sterna hirundo (ST): An occasional migrant, summer observations on the Hudson River are rare to uncommon.

\section{Reptiles}

Bog turtle, Clemmys muhlenbergii (C2, SE): Former bog turtle sites on Palisades Interstate Park property are less than $1.6 \mathrm{~km}$ from West Point. This species has been collected from Popolopen Lake. Some wetlands, particularly the Firebreak \#1 Beavers Pond, are suitable habitat. 
Timber rattlesnake, Crotalus horridus (ST): Known to occur on the reservation, this species is an uncommon resident of the reservation, and a rare resident of the Main Post. It is most frequently encountered in the training area and near Wilkens and Round Ponds. It has been collected from Popolopen Lake.

Eastern mud turtle, Kinosternum subrubrum (ST): West Point is on the far northern edge of the species range. It may occur on the reservation, but would be rare.

\section{Mammals}

Mountain lion, Felis concolor cougari (FE, SE): Although the lion may be extinct, historically, it was found in this area.

Small-footed bat, Myotis sublatus leibii (C2): Although this bat is rare in New York, its occurrence on the reservation is possible. These bats hibernate in caves and roost in trees or other man-made structures in summer.

Indiana bat, Myotis sodalis (FE, SE): Bat colonies have been found in the area, and the bat may occur as a transient on the reservation.

Eastem woodrat, Neotoma floridana magister (C2, SE): This species has been collected on Popolopen Lake. Active sites also exist at Storm King, $1.6 \mathrm{~km}$ north of West Point.

\section{Amphibians}

Northern cricket frog, Acris crepitans crepitans (ST): Recorded within the range of the reservation, the frog may be found in the area.

\section{Fish}

Shortnose sturgeon, Acipenser brevirostrum (FE, SE): This fish may be found in the Hudson River adjacent to the reservation.

\section{Endangered Species Summary}

The bald eagle is known as a rare winter visitor and the peregrine falcon is a possible migrant. The shortnose sturgeon may be found in the Hudson River. The Indiana and small-footed bats may be seen on the reservation. The northern harrier is a common fall migrant, and the golden eagle is a rare winter visitor. The osprey occurs as a regular migrant and the loggerhead shrike is a rare migrant. The red-shouldered hawk may breed in the area. The bog turtle, timber rattlesnake, and the Eastern woodrat are known to occur around Popolopen Lake. The range of the northern cricket frog includes the reservation. 
VOLUNTEER AAP

Main County: Hamilton

Surrounding Counties: Bledsoe, Bradley, Marion, Meigs, Rhea, Sequatchie, TN; Walker, Dade, Catoosa, GA

\section{VERTEBRATES}

\section{Birds}

Cooper's hawk, Accipiter cooperii (ST/ESD:" SE): Although it is rare, this hawk is considered a permanent resident throughout Tennessee and may be found anywhere in the state. It has been recorded in Sequatchie, Marion, and Bledsoe. Counties from April through August and Meigs and Bledsoe Counties from September through March. From September through November, additional migrants from the north are present, and the hawk most would likely be seen at this time.

Sharp-shinned hawk, Accipiter striatus (ST, ESD: SE): An uncommon to rare permanent resident that may be found in any Tennessee county, this hawk has been recorded at various times of the year in Hamilton County. It may be found within the installation.

Bachman's sparrow, Aimophila aestivalis (C2, SE, ESD: SE): This species occurs in Hamilton County. It usually inhabits open pastures, thick grass with low trees, and open woodlands. Occurrence on the installation is possible.

Golden eagle, Aquila chrysaetos (SE, ESD: ST): An uncommon winter visitor and transient, the eagle was recorded in Hamilton and Marion Counties year round.

Great blue heron, Ardea herodias (ESD: ST): An uncommon to rare permanent resident, the herons are more common in eastern Tennessee in the winter months. The great blue has been recorded in Hamilton County year round. These birds require freshwater marsh areas for breeding and feeding.

American bittern, Botaurus lentiginosus (ESD: SE): An uncommon permanent resident of low-lying marshy habitats, this species has been recorded in March through September and October through February in Hamilton County. Most bitterns are observed during migration.

Northem harrier, Circus cyaneus hudsonius (ST): Throughout the state this bird is an uncommon to rare transient in spring and fall and an uncommon to rare winter visitor. Recorded from August to May in Hamilton County, its occurrence on the installation is possible.

American peregrine falcon, Falco peregrinus anatum (FE, SE): An uncommon to rare transient in the spring and fall, an occurrence on the installation is possible. Historical records show the falcon nested in Hamilton County. However, the birds have not nested in Tennessee for 25 years. The Ecological Services Division (ESD) of the Tennessee Department of Conservation maintains a separate listing of threatened
and endangered species that may differ from the state list maintained by the Tennessee Wildlife Resources Agency. 
Arctic peregrine falcon, Falco peregrinus tundrius (FE, SE): An uncommon to rare transient in the spring and fall, an occurrence on the installation is possible.

Common moorhen, Gallinula chloropus (SA, ESD: ST): An uncommon transient during spring and fall migrations, the moorhen has been recorded in Hamilton County from March through September. Occurrence in marsh areas on or around the installation is possible.

Sandhill crane, Grus canadensis (ESD: ST): An uncommon to local transient in the spring and fall, the birds are usually seen in flight or for brief periods as they stop to spend the night, to feed, or to rest. Cranes have been recorded in Hamilton County from March through June and August through December.

Southem bald eagle, Haliaeetus leucocephalus (leucocephalus) (FE, SE/ESD: SE): A wintering species, the eagle is usually seen from August to May and is known from Hamilton, Marion, Meigs, and Rhea Counties. Occurrence of these birds migrating or foraging near the installation is possible. Some of the wintering birds may be of the northern subspecies alascanus. No eagles have nested in Tennessee since 1958.

Least bittern; Ixobrychus exilis (ESD: ST): An uncommon to rare transient across the state from April to May and September to October, bitterns inhabit freshwater marshes and pond edges. These birds have been recorded as nesting in Hamilton County from April through mid-October. The occurrence of this species on the installation is possible.

Black-crowned night heron, Nycticorax nycticorax (ST, ESD: ST): An uncommon to rare permanent resident throughout Tennessee, this night heron was recorded in Hamilton County. These birds will nest in pine stands and are usually found in marshes, swamps, creeks, and wooded streams.

Yellow-crowned night heron, Nycticorax violaceus (ESD: ST): One pair nested from 1973 to 1977, in an area less than $8 \mathrm{~km}$ from the installation. The herons are usually found in forested areas near swamps or sloughs.

Osprey, Pandion haliaetus (SE, ESD: ST): A rare and local summer resident in Tennessee, the osprey was recorded in Hamilton County from April through October. The osprey also nested in Hamilton. In the spring and fall it is a common migrant. Although it is a rare wintering species, it has been recorded in Meigs County. Inhabiting areas around water, ospreys are found around streams, lakes, and ponds. Its occurrence on or around the installation is likely.

Red-cockaded woodpecker, Picoides borealis (FE, SE, ESD: SE): Historical records show this woodpecker occurred in Hamilton County, its range including the installation. This bird requires mature pine stands for nesting.

King rail, Rallus elegans (ESD: SE): An uncommon to rare transient and an uncommon to rare summer resident, the rail is mainly found in marshy habitats. There is a nesting record for this species in Hamilton County. This bird has also been recorded in the county from April through March.

Virginia rail, Rallus limicola (ESD: SE): An uncommon to rare transient and a rare winter visitor across Tennessee, the rail is also a rare and local summer resident. It has been recorded in Hamilton County year round. There is also a nesting record in Hamilton County. The birds breed in freshwater marshes and marshy fields but are sometimes found in drier brushy fields during migration. 
Bank swallow, Riparia riparia (ESD: ST): An uncommon to rare local summer resident and breeding bird across Tennessee, the swallow has been recorded April through October in Hamilton County. Swallows are found near water during migration and while nesting.

Interior least tern, Sterna antillarum atnallassos (FE, SE, ESD: SE): Although this species is an uncommon to rare transient in areas away from the Mississippi River, its occurrence on the installation is possible. In Tennessee it is considered an uncommon to rare transient and wanderer. It has been recorded in Hamilton County from late March through late September.

Appalachian Bewick's wren, Thryomanes bewickii altus (C1, ST, ESD: ST): A permanent resident across the state, this bird was recorded March through February in Hamilton County. The birds are usually found in thickets, brush piles, fence and hedgerows, and other areas with second growth.

Common barn owl, Tyto alba (ESD: SE): A rare to very uncommon resident in Tennessee, the owls are found in open rural areas as well as towns and cities. This species has been recorded in Hamilton County as a permanent resident and also as nesting. Occurrence on the installation is possible.

Bachman's warbler, Vermivora bachmani (FE, ESD: SP): This bird is considered the rarest warbler in North America. Although it's occurrence on the installation is not likely, historically it was probably a migrant in the state. It bred in states surrounding Tennessee.

\section{Mammals}

Red wolf, Canus rufus gregoryi (FE): Although this species is extirpated from Tennessee, historically it occurred within the area.

Eastern cougar, Felis concolor cougari (FE, SE, ESD: SE): This species could possibly occur in Marion County; the installation is within the southem part of its historical range. Wild populations still exist, making its occurrence possible.

Florida panther, Felis concolor coryi (FE, SE, ESD: SE): Although this species is very rare, the installation is within the northern part of its historical range. Wild populations still exist, making its occurrence possible.

Gray bat, Myotis grisescens (FE, SE, ESD: SE): Known to occur in Bledsoe, Marion, Meigs, Rhea, and Sequatchie Counties, these bats may be found foraging on the installation. Summer roosts are known to occur in Nickajack Cave.

Eastern small-footed bat, Myotis subulatus leibii (C2): Recorded in Marion County, this species may be seen on the installation foraging or as a migrant.

Indiana bat, Myotis sodalis (FE, SE, ESD: SE): Possibly occurs in all main and surrounding counties, these bats may be seen foraging in riparian areas around the installation.

Eastern woodrat, Neotoma floridana magister (C2): Little is known of its existence and/or abundance, but the preferred habitat is rocky, wooded areas and swampy or open areas. This species is listed as occurring in Hamilton County. Occurrence on the installation is possible. 


\section{Amphibians}

Hellbender, Cryptobranchus alleganiensis (C2): The installation is within the range of the hellbender.

Tennessee cave salamander, Gyrinophilus palleucus (C2, ST, ESD: ST): Listed as occurring in Hamilton County, this species may be found in caves on or around the installation.

\section{Fish}

Yellowfin madtom, Noturus flavipinnis (FT, SE, ESD: SE): Although extirpated from this location, this species historically was found in Chickamauga Creek near Chattanooga. It is presumed extirpated from this area because of impoundments and pollution.

Snail darter, Percina tanasi (FT, ST, ESD: SE): This species is known from Hamilton, Bradley, Marion, Meigs, and Rhea Counties. Several records list the darter as occurring in South Chickamauga Creek, in an area less than $12.8 \mathrm{~km}$ from the installation.

\section{INVERTEBRATES}

\section{Mollusks}

Eastern fanshell, Cyprogenia stegaria (FPE): This species was occasionally collected in the river and may still be present in waters around the installation.

Pearly dromedary mussel, Dromas dromas (FE, SE, ESD: SE): This mollusk is known from Meigs and Rhea Counties, and is listed as possibly occurring in Hamilton County. Historically recorded in the Tennessee River from Knox County, Tennessee down to Lauderdale County, Alabama, the occurrence of this species in waters around the installation is possible.

Tuberculed-blossom pearly mussel, Epioblasma (Dysnomia) torulosa torulosa (FE): Listed in Hamilton County. Historically this species was found in the Tennessee River from Knox County to Muscle Shoals, Alabama, but it is now thought to be extinct.

Epioblasma (=Dysnomia) torulosa (SE, ESD: SE): See E. torulosa torulosa above.

Pink mucket pearly mussel, Lampsilis orbiculata (= abrupta) (FE, SE): A Tennessee River species historically collected from Marion County, Tennessee to the Muscle Shoals, Alabama, it is listed as occurring in Hamiliton, Meigs, and Rhea Counties.

Orange-foot pimpleback, Plethobasus cooperianus (=striatus) (FE, SE, ESD: SE): In Hamilton County, this species was collected in the Tennessee River below the southern railroad bridge, $300 \mathrm{~m}$ below Chickamauga Dam. This area is less than $8 \mathrm{~km}$ from the installation.

Pale lilliput pearly mussel, Toxoplasma cylindrella (FE, SE, ESD: SE): Found in small rivers and streams that are tributaries of the Tennessee river, it may still be present in waters around the installation. 
Cumberland monkeyface, Quadrula intermedia (FE, SE, ESD: SE): This species has been recorded in the Tennessee River. Its occurrence in waters around the installation is possible.

Rough pigtoe, Pleurobema plenum (FE, SE, ESD: SE): Formerly found in the Tennessee River from Knoxville, Tennessee to northern Alabama this species was collected in Hamilton County. Because of the alteration of its habitat, the occurrence of this species in waters around the installation is unlikely.

\section{Other}

Chickamauga crayfish, Cambarus extraneus (C2, ESD: ST): Listed as occurring in south Chickamauga Creek, Hamilton County, about $1.6 \mathrm{~km}$ downstream from U. S. 11-64. This area is less than $12.8 \mathrm{~km}$ from the installation.

Spiny river snail, Io fluvialis (C1, ESD: SE): Historically this species was collected from the Tennessee River around Chattanooga, although it has not been collected there since 1970.

Onyx rock snail, Leptoxis praerosa (C2, SE, ESD: SE): Historically this species was found throughout the Tennessee River. Alterations of the river, however, have destroyed prime habitat.

Verrucose file snail, Lithasia verrucosa (C2, ESD: SE): Listed as occurring in Hamilton County, this species was historically found in the Tennessee River from Knox County to Chattanooga Tennessee.

\section{Endangered Species Summary}

Gray and Indiana bats and the bald eagle are the only federally endangered species likely to be found in the area. Bachman's sparrow, Bewick's wren, northern harrier, Cooper's and sharp-shinned hawks, night herons, osprey, and river otters are state listed species likely to be found. Fish and mollusk species listed may be found in waters in the area. 


\section{REFERENCES}

16 U.S. Code $\S 1536$ (a)(1)

16 U.S. Code $§ 1536$ (b)(4)(B)

16 U.S. Code $\S 1536$ (a)(3)

16 U.S. Code $\S 1538$ (a) (1)(B),(C)

16 U.S. Code § 1539 (a)(1)(2)(A)

16 U.S. Code $\S 1539$ (a)(1)(2)(B)

50 Code of Federal Regulations (CFR) $§ 402$

50 (CFR) § 450-453

46 Federal Register (FR) 54748, 54750 (4 Nov 81)

50 (FR) (188); 39526-39527, "Endangered and Threatened Wildlife and Plants; Review of Plant Taxa for Listing as Endangered or Threatened Species; Notice of Review."

51 (FR) 19948 (3 June 1986)

54 (FR) 554-579, Endangered Species: Management Improvements Could Enhance Recovery Program, GAO/RCED-89-5 (U.S. General Accounting Office [GAO], 1989, pp 1-100; 6 Jan 1989)

54 (FR) 7539-7543, 265.7(B) (3)(b) [22 February 1989].

54 (FR) 7542 (February 1989)

Aplet, G.H., et.al., A Preliminary Status Report for Haplostachys haplostachya (A. Gray) St. John, an Endangered Mint Restricted to Pohakuloa Training Area, Hawaii. USACERL Draft Status Report.

Army Regulation (AR) 420-74 Natural Resource - Land, Forest, and Wildlife Management (Headquarters, Paragraph 6-2 (Department of the Army [HQDA], 25 February 1986.

Bagley, C.F. and J.D. Mastrogiuseppe, Columbia Milkvetch, Astragulus columbianus Barneby on Yakima Firing Center, Washington. USACERL Draft Status Report.

Bean, M.J., The Evolution of National Wildlife Law: Revised and Expanded Edition (Praeger Publishers, New York, 1983).

Brozka, R.J., Todson's Pennyroyal, Hedeoma todsenii Irving on White Sands Missile Range, New Mexico. USACERL Draft Status Report.

Diersing, V.E., W.D. Severinghaus, and E.W. Novak, Annotated Directory of Endangered Wildlife on Selected U.S. Army Installations West of the Mississippi River. Technical Report N-85/08/ ADA 154623 (U.S. Army Construction Engineering Research Laboratory [USACERL], March 1985). 
Henifin, M.S., et. al., "Guidelines for the Preparation of Status Reports on Rare or Endangered Plant Species." Rare Plant Conservation: Geographical Data Organization, L.E. Morse and M.S. Henifin, Eds. (The New York Botanical Garden, New York, 1981).

"Legislative History: Endangered Species Act Amendments of 1988--African Elephant Conservation (P.L. 100-478)", U.S. Code: Congressional and Administrative News, Vol 8A (West Publishing Co., 1988), pp 2700-2750.

Palila v Hawaii Department of Land and Natural Resources 639 F. 2d 495 (9th Cir. 1981), and Pilila v Hawaii Department of Land and Natural Resources 852 F. 2d 1106 (9th Cir. 1988).

Rohlf, D.J., The Endangered Species Act, a Guide to its Protections and Implementation, (Stanford Environmental Law Society, Stanford, CA, 1989).

Yaffee, S.L. "Protecting Endangered Species Through Interagency Consultation," Endangered Species Update 5:14-19 (1988).

Schulz, K.A., R.B. Shaw, and D.J. Tazik. Status of Haplopappus fremontii A. Gray subsp. monocephalus (A. Nels.) H.M. Hall (Asteraceae) on the U.S. Army Pinon Canyon Maneuver Site, Colorado. Phytologia submitted. 1991.

Technical Bulletin (TB), Endangered Species, Vol 15, No. 2 (U.S. Department of the Interior, 1989) p 8.

Technical Note (TN) 420-74-2, Facilities Engineering Natural Resources Management, Endangered Species Management Requirements on Army Installations U.S. Army Engineering and Housing Support Center [USAEHSC], 17 NOVEMBER 1989).

Tennessee Valley Authority v Hill 437 U.S. 153 (1978). 


\begin{tabular}{|c|c|c|c|}
\hline Installation & MACOM & Taxon & Species \\
\hline Aberdeen PG & AMC & Amphiblan & Hellbender \\
\hline Aberdeen PG & AMC & Rept 11 e & Bog turtle \\
\hline Aberdeen PG & AMC & Mammal & Eastern small-footed bat \\
\hline Aberdeen PG & AMC & B1rd & Migrant loggerhead shrlke \\
\hline Aberdeen PG & AMC & Bird & American peregrine falcon \\
\hline Aberdeen PG & AMC & BIrd & K1rtland's warbler \\
\hline Aberdeen PG & AMC & Fish & Shortnose sturgeon \\
\hline Aberdeen PG & AMC & Fish & Maryland darter \\
\hline Aberdeen PG & AMC & Bird & Bald eagle \\
\hline Aberdeen PG & AMC & Bird & Arctic peregrine falcon \\
\hline Aberdeen PG & AMC & Rept1le & Atlant1c loggerhead turtle \\
\hline Anniston $A D$ & AMC & Bird & Appalachlan Bewlck's wren \\
\hline Anniston $\mathrm{AD}$ & AMC & Fish & Blue shiner \\
\hline Anniston $A D$ & AMC & Mollusk & Alabama llve-bearing snall \\
\hline Anniston $A D$ & AMC & Fish & Coldwater darter \\
\hline Anniston $A D$ & AMC & Mollusk & Fine-Ilned pocketbook \\
\hline Anniston $\mathrm{AD}$ & AMC & Mollusk & Sculpin snail \\
\hline Anniston $A D$. & AMC & Mollusk & Upland combshell \\
\hline Anniston $A D$ & AMC & Mamma 1 & Gray bat \\
\hline Anniston $\mathrm{AD}$ & AMC & Bird & Red-cockaded woodpecker \\
\hline Anniston $A D$ & AMC & Mamma 1 & Florida panther \\
\hline Anniston AD & AMC & Mamma 1 & Indiana bat \\
\hline Anniston $\mathrm{AD}$ & AMC & Mamma 1 & Red wolf \\
\hline Anniston $A D$ & AMC & Mollusk & Judge Talt's mussel \\
\hline Anniston $\mathrm{AD}$ & AMC & B1rd & American peregrine falcon \\
\hline Anniston $A D$ & AMC & Bird & Bald eagle \\
\hline Anniston $\mathrm{AD}$ & AMC & B1rd & Bachman's warbler \\
\hline Anniston $A D$ & AMC & Bird & Arct 1c peregrine falcon \\
\hline Anniston $A D$ & AMC & Fish & Pygmy sculpin \\
\hline Bager AAP & AMC & Mollusk & winged mapleleaf \\
\hline Bager AAP & AMC & Fish & Paddlefish \\
\hline Bager AAP & AMC & Fish & Lake sturgeon \\
\hline Bager AAP & AMC & Mollusk & Salamander mussel \\
\hline Bager AAP & AMC & Rept 1 le & Eastern massasauga \\
\hline Bager AAP & AMC & Bird & Migrant loggerhead shrike \\
\hline Bager AAP & AMC & Fish & Blue sucker \\
\hline Bager AAP & AMC & Bird & P1ping plover \\
\hline Bager AAP & AMC & B1rd & Amertcan peregrine falcon \\
\hline Bager AAP & AMC & Bird & Bald eagle \\
\hline Bager AAP & AMC & B1rd & Arct 1c peregrine falcon \\
\hline Bager AAP & AMC & Rept $11 \mathrm{e}$ & Western ribbon snake \\
\hline Bager AAP & AMC & Insect & S1lphlum borer moth \\
\hline Bager AAP & AMC & B1rd & Osprey \\
\hline Bager AAP & AMC & Bird & Caspian tern \\
\hline Bager AAP & AMC & B1rd & Barn ow 1 \\
\hline Bager AAP & AMC & Fish & Goldeye \\
\hline Bager AAP & AMC & Bird & Worm-eat1ng warbler \\
\hline Bager AAP & AMC & Reptile & Northern ribbon snake \\
\hline Bager AAP & AMC & B1rd & Eorster's tern \\
\hline Bager AAP & AMC & Reptile & Western slender glass lizard \\
\hline Bager AAP & AMC & B1rd & Yellow-throated warbler \\
\hline Bager AAP & AMC & Reptile & Western box turtle \\
\hline Bager AAP & AMC & Amphibian & Blanchard's cricket frog \\
\hline Bager AAP & AMC & B1rd & Cerulean warbler \\
\hline Bager AAP & AMC & Mollusk & Buckhorn \\
\hline Bager AAP & AMC & Fish & Speckled chub \\
\hline Bager AAP & AMC & B1rd & Acadian flycatcher \\
\hline Bager AAP & AMC & Mollusk & Rock pocketbook \\
\hline Bager AAP & AMC & Reptile & Wood turtle \\
\hline Bager AAP & AMC & B1rd & Red-shouldered hawk \\
\hline Bager AAP & AMC & Rept11e & Blanding's turtle \\
\hline Bager AAP & AMC & Bird & Great egret \\
\hline Bager AAP & AMC & BIrd & Kentucky warbler \\
\hline Bager AAP & AMC & Fish & Redfin shiner \\
\hline Camp Atterbury & NGB & Bird & Bachman's sparrow \\
\hline Camp Atterbury & NGB & B1rd & Mlgrant loggerhead shrike \\
\hline Camp Atterbury & NGB & Fish & Eastern sand darter \\
\hline Camp Atterbury & NGB & Reptile & Kirtland's snake \\
\hline Camp Atterbury & NGB & Mamma 1 & Indlana bat \\
\hline Camp Atterbury & NGB & Mamma I & Gray bat \\
\hline Camp Atterbury & NGB & B1rd & American peregrine falcon \\
\hline Camp Atterbury & NGB & B1rd & Bald eagle \\
\hline Camp Atterbury & NGB & Blrd & Yellow-crowned nlght heron \\
\hline Camp Atterbury & NGB & Mamma l & Evening bat \\
\hline Camp Atterbury & NGB & B1rd & Black-crowned night heron \\
\hline Camp Atterbury & NGB & Mamma 1 & Bobcat \\
\hline Camp Atterbury & NGB & B1rd & American bittern \\
\hline Camp Atterbury & NGB & Bird & Great egret \\
\hline Camp Atterbury & NGB & B1rd & Golden-winged warbler \\
\hline
\end{tabular}

Status Residency Occurrance

\begin{tabular}{|c|c|c|c|}
\hline $\mathrm{C} 2$ & $\mathrm{SE}$ & YR & Possible \\
\hline C2 & & YR & Current \\
\hline C2 & & M & Possible \\
\hline$c 2$ & $\mathrm{SE}$ & YR & Possible \\
\hline $\mathrm{FE}$ & & M & Possible \\
\hline$F E$ & & M & Possible \\
\hline $\mathrm{FE}$ & & YR & Possible \\
\hline FE & & YR & Current \\
\hline $\mathrm{FE}$ & & YR & Current \\
\hline ET & & M & Possible \\
\hline FT & & Adjacent & Possible \\
\hline $\mathrm{CI}$ & ST & YR & Possible \\
\hline C2 & & YR & Possible \\
\hline C2 & & YR & Posslble \\
\hline $\mathrm{c} 2$ & & YR & Possible \\
\hline C2 2 & & YR & Possible \\
\hline $\mathrm{C} 2$ & & YR & Possible \\
\hline C2 & & YR & Possible \\
\hline $\mathrm{FE}$ & & $\mathrm{F}, \mathrm{M}$ & Possible \\
\hline FE & & YR & Possible \\
\hline FE & & YR & Extirpated \\
\hline $\mathrm{FE}$ & & $B, F, M$ & Possible \\
\hline FE & & YR & Ext1rpated \\
\hline $\mathrm{FE}$ & & YR & Possible \\
\hline FE & & $\mathrm{T}$ & Unlikely \\
\hline FE & & $\mathrm{T}$ & Possible \\
\hline$F E$ & & $\mathrm{~T}$ & Extirpated \\
\hline FT & & T & Unlikely \\
\hline FT & & YR & Possible \\
\hline $3 \mathrm{C}$ & SE & YR & Possible \\
\hline $3 \mathrm{C}$ & ST & YR & Unlikely \\
\hline C2 & & YR & Unl1kely \\
\hline $\mathrm{C} 2$ & ST & YR & Possible \\
\hline C2 & SE & YR & Possible \\
\hline C2 & $S E$ & B & Possible \\
\hline C2 & & YR & Possible \\
\hline EE & & M & Possible \\
\hline FE & & B & Possible \\
\hline FT & & W & Possible \\
\hline FT & & M & Possible \\
\hline $\mathrm{SE}$ & & $Y R$ & Possible \\
\hline$S E$ & & & Possible \\
\hline$S E$ & & M & Possible \\
\hline$S E$ & & M & Possible \\
\hline$S E$ & & YR & Possible \\
\hline SE & & YR & Possible \\
\hline$S E$ & & B & Possible \\
\hline SE & & YR & Possible \\
\hline SE & & M & Possible \\
\hline$S E$ & & YR & Possible \\
\hline SE & & M & Possible \\
\hline SE & & YR & Possible \\
\hline$S E$ & & YR & Possible \\
\hline ST & & M & Possible \\
\hline ST & & YR & Possible \\
\hline ST & & YR & Possible \\
\hline ST & & M & Possible \\
\hline ST & & $Y R$ & Possible \\
\hline ST & & YR & Possible \\
\hline ST & & B & Possible \\
\hline ST & & YR & Posslble \\
\hline ST & & B & Possible \\
\hline ST & & $\bar{M}$ & Possible \\
\hline ST & & YR & Unlikely \\
\hline $\mathrm{C} 2$ & $S E$ & YR & Posstble \\
\hline $\mathrm{C} 2$ & & M & Possible \\
\hline $\mathrm{C} 2$ & & YR & Possible \\
\hline $\mathrm{C} 2$ & & YR & Possible \\
\hline FE & & M & Possible \\
\hline $\mathrm{FE}$ & & PB & Possible \\
\hline FE & & M & Current \\
\hline FE & & M & Current \\
\hline SE & & B & Possible \\
\hline SE & & B & Possible \\
\hline SE & & B & Current \\
\hline$S E$ & & YR & Possible \\
\hline $\mathrm{SE}$ & & B & Possible \\
\hline $\mathrm{SE}$ & & PB & Possible \\
\hline$S E$ & & B & Possible \\
\hline
\end{tabular}




\section{Appendix A (continued)}

\begin{tabular}{|c|c|c|c|c|c|c|c|c|c|}
\hline \multicolumn{2}{|c|}{ Installation } & MACOM & Taxon & Species & Status & Res & idency & Occurrance & \\
\hline Camp & Atterbury & NGB & B1rd & King rall & SE & & B & Current & \\
\hline Camp & Atterbury & NGB & B1rd & Barn ow 1 & SE & & YR & Possible & $\mathrm{R}$ \\
\hline Camp & Atterbury & NGB & Bird & Osprey & SE & & M & Possible & R \\
\hline Camp & Atterbury & NGB & B1rd & Upland sandplper & SE & & B & Possible & R \\
\hline Camp & Atterbury & NGB & Mollusk & Pink papershell mussel & SE & & YR & Possible & $\mathrm{N}$ \\
\hline Camp & Atterbury & NGB & Bird & Bewick's wren & $S E$ & & B & Possible & R \\
\hline Camp & Atterbury & NGB & Mamma 1 & Badger & ST & & YR & Current & \\
\hline Camp & Atterbury & NGB & B1rd & Sedge wren & ST & & B & Possible & $\mathrm{R}$ \\
\hline Camp & Atterbury & NGB & Bird & Henslow's sparrow & ST & & B & Possible & R \\
\hline Camp & Atterbury & NGB & B1rd & Northern harrler & ST & & YR & Current & \\
\hline Camp & Blanding & NGB & Mamma 1 & Sherman's fox squirrel & $\mathrm{C} 2$ & & YR & Current & \\
\hline Camp & Blanding & NGB & Mamma 1 & Florlda black bear & $\mathrm{C} 2$ & ST & $T$ & Possible & $\mathrm{N}$ \\
\hline Camp & Blanding & NGB & Amphiblan & Gopher frog & $\mathrm{C} 2$ & & YR & Current & \\
\hline Camp & Blandlng & NGB & Bird & Southeastern American kestrel & $\mathrm{C} 2$ & ST & YR & Current & \\
\hline Camp & Blanding & NGB & Rept1le & Gopher tortolse & $\mathrm{C} 2$ & & YR & Current & \\
\hline Camp & Blanding & NGB & Bird & Bald eagle & $\mathrm{EE}$ & & $B, F$ & Possible & N \\
\hline Camp & Blanding & NGB & Mamma 1 & Red wolf & $\mathrm{FE}$ & & YR & Extirpated & HR \\
\hline Camp & Blanding & NGB & B1rd & American peregrine falcon & $\mathrm{EE}$ & & w & Possible & $\mathrm{R}$ \\
\hline Camp & Blanding & NGB & Bird & Bachman's warbler & $\mathrm{FE}$ & & W & Extirpated & HR \\
\hline Camp & Blanding & NGB & B1rd & Wood stork & EE & & YR & Possible & $\mathrm{N}$ \\
\hline Camp & Blanding & NGB & B1rd & Ivory-b1lled woodpecker & FE & & YR & Extirpated & HR \\
\hline Camp & Blanding & NGB & B1rd & Red-cockaded woodpecker & $\mathrm{FE}$ & & YR & Current & \\
\hline Camp & Blandlng & NGB & Mamma 1 & Florida panther & EE & & YR & Unlikely & HR \\
\hline Camp & Blanding & NGB & Bird & Arct 1c peregrine falcon & FT & & W & Possible & $\mathrm{R}$ \\
\hline Camp & Blandling & NGB & Bird & Florlda scrub Jay & ET & & YR & Current & \\
\hline Camp & Blanding & NGB & Rept1le & Eastern Indigo snake & ET & & YR & Likely & $\mathrm{N}^{*}$ \\
\hline Camp & Blanding & NGB & Reptile & American alligator & ETSA & & YR & Likely & R \\
\hline Camp & Edwards & NGB & Bird & Migrant loggerhead shrike & C2 & & M & Possible & $\mathrm{R}$ \\
\hline Camp & Edwards & NGB & Mamma 1 & Eastern small-footed bat & $\mathrm{C} 2$ & & F, M & Possible & R \\
\hline Camp & Edwards & NGB & Mamma 1 & New England cottonta11 & $\mathrm{C} 2$ & & YR & Possible & $\mathrm{N}$ \\
\hline Camp & Edwards & NGB & B1rd & Amerlcan peregrine falcon & $\mathrm{FE}$ & & $B$ * & Possible & $\mathrm{R}$ \\
\hline Camp & Edwards & NGB & B1rd & Bald eagle & $\mathrm{FE}$ & & F & Possible & $\mathrm{N}$ \\
\hline Camp & Edwards & NGB & B1rd & Roseate tern & $\mathrm{FE}$ & & F, M & Possible & $\mathrm{R}$ \\
\hline Camp & Edwards & NGB & Fish & Shortnose sturgeon & FE & & Adjacent & Possible & $\mathrm{R}$ \\
\hline Camp & Edwards & NGB & B1rd & Pipling plover & ET & & B & Possible & $\mathrm{N}$ \\
\hline Camp & Edwards & NGB & B1rd & Arctic peregrine falcon & ET & & M & Possible & $\mathrm{R}$ \\
\hline Camp & Edwards & NGB & Bird & Henslow's sparrow & SE & & B & Possible & $\mathrm{R}$ \\
\hline Camp & Edwards & NGB & B1rd & Short-eared owl & SE & & B & Possible & $\mathrm{N}$ \\
\hline Camp & Edwards & NGB & Bird & Upland sandplper & SE & & B & Current & \\
\hline Camp & Edwards & NGB & Bird & Northern harrier & ST & & YR & Likely & $\mathrm{N}$ \\
\hline Camp & Edwards & NGB & Amphibian & Eastern spadefoot toad & ST & & YR & Possible & $\mathrm{N}$ \\
\hline Camp & Edwards & NGB & B1rd & King ra 11 & ST & & YR & Possible & R \\
\hline Camp & Edwards & NGB & Insect: & Gerhard's underwing moth & ST & & & Current & \\
\hline Camp & Edwards & NGB & Fish & Amerlcan brook lamprey & ST & & Adjacent & Possible & $\mathrm{R}$ \\
\hline Camp & Edwards & NGB & Amphiblan & Marbled salamander & ST & & YR & Possible & $\mathrm{N}$ \\
\hline Camp & Edwards & NGB & Blid & Northern parula & ST & & B & Possible & $\mathrm{R}$ \\
\hline Camp & Edwards & NGB & B1rd & Pled-billed grebe & ST & & B & Possible & $\mathrm{R}$ \\
\hline Camp & Grayling & NGB & B1rd & Migrant loggerhead shrike & $\mathrm{C} 2$ & SE & B & Unllkely & $\mathrm{N}$ \\
\hline Camp & Grayling & NGB & B1rd & American peregrine falcon & $\mathrm{FE}$ & & $\mathrm{T}$ & Possible & $\mathrm{R}$ \\
\hline Camp & Grayling & NGB & B1rd & K1rtland's warbler & $\mathrm{FE}$ & & B & Current & \\
\hline Camp & Grayling & NGB & B1rd & Arctic peregrine falcon & ET & & T & Possible & R \\
\hline Camp & Grayling & NGB & B1rd & Bald eagle & FT & & YR & Current & \\
\hline Camp & Grayling & NGB & B1rd & King rail & SE & & B & Possible & $\mathrm{R}$ \\
\hline Camp & Grayling & NGB & B1rd & Short-eared ow 1 . & SE & & B & Possible & R \\
\hline Camp & Grayllng & NGB & B1rd & Merlin & ST & & $\mathrm{T}$ & Possible & $\mathrm{R}$ \\
\hline Camp & Grayling & NGB & Mollusk & Deep water pond snall & ST & & YR & Possible & N \\
\hline Camp & Grayling & NGB & F1sh & Cisco & ST & & YR & Possible & $\mathrm{R}$ \\
\hline Camp & Grayling & NGB & B1rd & Red-shouldered hawk & ST & & B & Possible & $\mathrm{N}$ \\
\hline Camp & Grayling & NGB & B1rd & Common loon & ST & & B, E & Possible & N \\
\hline Camp & Grayling & NGB & B1rd & Osprey & ST & & B & Possible & $\mathrm{N}$ \\
\hline Camp & Santlago & NGB & Bird & Yellow-shouldered blackbird & $\mathrm{FE}$ & & YR & Possible & $\mathrm{N}$ \\
\hline Camp & Santiago & NGB & B1rd & American peregrine falcon & $\mathrm{FE}$ & & W & Possible & $\mathrm{N}$ \\
\hline Camp & Santiago & NGB & Rept1le & Puerto Rican boa & $\mathrm{EE}$ & & YR & Current & \\
\hline Camp & Sant1ago & NGB & Rept1le & Golden coqui & $\mathrm{FE}$ & & YR & Possible & $\mathrm{N}$ \\
\hline Camp & Santlago & NGB & Bird & Brown pelican & FE & & I & Possible & $\mathrm{N}$ \\
\hline Camp & Santiago & NGB & B1rd & Peurto Rican plain plgeon & $\mathrm{FE}$ & & YR & Possible & $\mathrm{N}$ \\
\hline Camp & Santlago & NGB & Reptile & Puerto R1can crested toad & ET & & YR & Possible & NH \\
\hline Camp & Sant1ago & NGB & B1rd & Piping plover & ET & & $\mathrm{T}$ & Current & \\
\hline Camp & Santiago & NGB & Bird & Roseate tern & FT & & B & Possible & $\mathrm{N}$ \\
\hline Camp & Santlago & NGB & B1rd & Arctic peregrine falcon & ET & & W & Possible & $\mathrm{N}$ \\
\hline Camp & Shelby & NGB & Rept 1le & Black pine snake & $\mathrm{C} 2$ & SE & YR & Current & \\
\hline Camp & shelby & NGB & Bird & Bachman's sparrow & $\mathrm{C} 2$ & & YR & Possible & $\mathrm{N}$ \\
\hline Camp & Shelby & NGB & B1rd & Amerlcan peregrine falcon & $\mathrm{FE}$ & & M & Possible & $\mathrm{R}$ \\
\hline Camp & Shelby & NGB & Mamma $\perp$ & Red wolf & $\mathrm{FE}$ & & YR & Ext1rpated & HR \\
\hline Camp & Shelby & NGB & Mamma 1 & Florida panther & $\mathrm{FE}$ & & YR & Unlikely & $H R$ \\
\hline Camp & Shelby & NGB & B1rd & Red-cockaded woodpecker & $\mathrm{FE}$ & & YR & Current & \\
\hline Camp & Shelby & NGB & Reptile & Eastern Indlgo snake & ET & & YR & Possible & $\mathrm{R}$ \\
\hline Camp & Shelby. & NGB & Rept 1le & Gopher tortolse & FT & & YR & Current & \\
\hline Camp & Shelby & NGB & Reptile & American alligator & ETSA & & YR & Possible & N \\
\hline Fort & Belvoir & MDW & Mamma 1 & Southern pygmy shrew & $\mathrm{C} 2$ & & YR & Possible & HR \\
\hline Fort & Belvolr & MDW & B1rd & Mlgrant loggerhead shrike & $\mathrm{C} 2$ & SE & B & Possible & $\mathrm{NH}$ \\
\hline Fort & Belvoir & MDW & B1rd & Bald eagle & $\mathrm{FE}$ & & $\mathrm{F}$ & Possible & $\mathrm{N}$ \\
\hline Fort & Belvoir & MDW & B1rd & American peregrine falcon & $\mathrm{FE}$ & & M & Possible & $\mathbf{R}$ \\
\hline Eort & Belvolr & MDW & Bird & Bachman's warbler & $\mathrm{FE}$ & & T & Ext1rpated & $\mathrm{HR}$ \\
\hline Fort & Belvolr & MDW & Bird & Yellow-crowned night heron & RSE & & B & Possible & R \\
\hline
\end{tabular}


Appendix A (continued)

\begin{tabular}{|c|c|c|c|c|c|c|c|c|c|}
\hline \multicolumn{2}{|c|}{ Installation } & MACOM & Taxon & Species & Status & & esidency & Occurranc & \\
\hline $\begin{array}{l}\text { Fort } \\
\text { Fort }\end{array}$ & $\begin{array}{l}\text { Belvolr } \\
\text { Belvolr }\end{array}$ & $\begin{array}{l}\text { MDW } \\
\text { MDW }\end{array}$ & $\begin{array}{l}\text { B1rd } \\
\text { Rept1le }\end{array}$ & $\begin{array}{l}\text { Northern harrier } \\
\text { Wood turtle }\end{array}$ & RSE & & $\underset{Y R}{M}$ & Possible & $\mathbf{R}$ \\
\hline Fort & Belvolr & MDW & B1rd & $\begin{array}{l}\text { Wood turtle } \\
\text { Henslow's sparrow }\end{array}$ & $\begin{array}{l}\text { RSE } \\
\text { RSE }\end{array}$ & & $\begin{array}{r}\mathrm{YR} \\
\mathrm{B}\end{array}$ & $\begin{array}{l}\text { Current } \\
\text { Possible }\end{array}$ & $\mathrm{R}$ \\
\hline Fort & Benning & TRADOC & B1rd & Appalachlan Bew1ck's wren & $\mathrm{C} 1$ & ST & W & Possible & $\mathrm{R}$ \\
\hline Fort & Benning & TRADOC & Mollusk & Shiny-rayed pocketbook & $\mathrm{C} 2$ & & YR & Possible & $\mathrm{N}$ \\
\hline Fort & Benning & TRADOC & Mollusk & Albany snall & c2 & & YR & Possible & $\mathrm{N}$ \\
\hline Fort & Benning & TRADOC & Fish & Bluestripe shiner & $\mathrm{C} 2$ & & YR & Possible & R \\
\hline Fort & Benning & TRADOC & Mollusk & Oval pigtoe & C2 & & YR & Possible & $\mathrm{N}$ \\
\hline Fort & Benning & TRADOC & Mollusk & Inned pocketbook & C2 & & YR & Possible & $\mathrm{N}$ \\
\hline Fort & Benning & TRADOC & Bird & Bald eagle & EE & & F & Possible & $\mathrm{R}$ \\
\hline Fort & Benning & TRADOC & B1rd & American peregrine falcon & FE & & M & Possible & $\mathrm{R}$ \\
\hline Fort & Benning & TRADOC & Reptile & Gopher tortolse & FE & & YR & Current & \\
\hline Fort & Benning & TRADOC & B1rd & Red-cockaded woodpecker & FE & & YR & Current & \\
\hline Fort & Benning & TRADOC & Mamma 1 & Eastern cougar & EE & & T & Unl1kely. & HR \\
\hline Fort & Benning & TRADOC & Mamma 1 & Indiana bat & FE & & E, M & Possible & $\mathbf{R}$ \\
\hline Fort & Benning & TRADOC & Mamma 1 & Florida panther & $\mathrm{FE}$ & & YR & Ext1rpated & $\mathrm{HR}$ \\
\hline Fort & Benning & TRADOC & Mamma 1 & Red wolf & FE & & YR & Extlypated & HR \\
\hline Fort & Benning & TRADOC & Bird & Wood stork & FE & & PB & Possible & $\mathrm{R}$ \\
\hline Fort & Benning & TRADOC & B1rd & Arctic peregrine falcon & FT & & M & Possible & $\mathrm{R}$ \\
\hline Fort & Benning & TRADOC & Reptile & American alílgator & FTSA & & YR & Current & \\
\hline Fort & Bragg & FORSCOM & Bird & Bachman's sparrow & $\mathrm{C} 2$ & ST & YR & Current & \\
\hline Fort & Bragg & FORSCOM & Mollusk & Cape Fear splke pearly mussel & C2 & ST & YR & Possible & $\mathrm{N}$ \\
\hline Fort & Bragg & EORSCOM & F1sh & Sandh111s chub & C2 2 & & YR & Rossible & $\mathrm{N}$ \\
\hline Eort & Bragg & FORSCOM & Bird & Red-cockaded woodpecker & $\mathrm{FE}$ & & YR & Current & \\
\hline Fort & Bragg & PORSCOM & B1rd & K1rtland's warbler & FE & & M & Possible & $\mathrm{R}$ \\
\hline Fort & Bragg & FORSCOM & Mamma 1 & Eastern cougar & FE & & YR & Ext1rpated & HR \\
\hline Fort & Bragg & FORSCOM & B1rd & Bald eagle & FE & & YR & Possible & $\mathrm{R}$ \\
\hline Fort & Bragg & FORSCOM & B1rd & American peregrine falcon & FE & & พ & Possible & $\mathbf{R}$ \\
\hline Fort & Bragg & FORSCOM & B1rd & Bachman's warbler & FE & & B & Extirpated & HR \\
\hline Fort & Bragg & FORSCOM & Mamma 1 & Red wolf & FE & & YR & Extirpated & HR \\
\hline Eort & Bragg & EORSCOM & B1rd & Ivory-billed woodpecker & EE & & YR & Ext1rpated & HR \\
\hline Fort & Bragg & FORSCOM & B1rd & Arctic peregrine falcon & FT & & w & Possible & R \\
\hline Fort & Bragg & FORSCOM & Rept1le & American alligator & ETSA & & YR & Current & \\
\hline Fort & Campbe 11 & FORSCOM & Bird & Appalachlan Bewick's wren & C1 & ST & YR & Possible & $\mathrm{N}$ \\
\hline Fort & Campbe11 & FORSCOM & Mollusk & Cumberland combshell & $\mathrm{C2}$ & SE & YR & Possible & $\mathrm{NH}$ \\
\hline Fort & Campbell & FORSCOM & B1rd & Mlgrant loggerhead shrike & C2 & & YR & Possible & $\mathrm{R}$ \\
\hline Fort & Campbe 11 & EORSCOM & Mamma 1 & Eastern small-footed bat & C2 & & YR & Possible & $\mathrm{R}$ \\
\hline Fort & Campbel1 & FORSCOM & Mollusk & Rugged river snall & C2 & SE & YR & Possible & $\mathrm{NH}$ \\
\hline Fort & Campbell & EORSCOM & Mollusk & Armored rocksnall & $\mathrm{C} 2$ & & YR & Possible & $\mathrm{NH}$ \\
\hline Fort & Campbe11 & FORSCOM & Mamma 1 & Southern pygmy shrew & C2 & & YR & Possible & $\mathrm{R}$ \\
\hline Fort & Campbel1 & FORSCOM & Rept1le & Northern pine snake & C2 & ST & YR & Possible & $\mathrm{R}$ \\
\hline Fort & Campbe11 & FORSCOM & Rept1le & Copperbelly water snake & $\mathrm{C} 2$ & & YR & Possible & $\mathrm{N}$ \\
\hline Fort & Campbell & FORSCOM & Rept1le & Aliligator snappling turtle & $\mathrm{C2}$ & ST & YR & Possible & $\mathrm{N}$ \\
\hline Fort & Campbe11 & FORSCOM & F1sh & Blue sucker & $\mathrm{C2}$ & SE & Ad Jacent & Possible & $\mathrm{N}$ \\
\hline Fort & Campbe11 & FORSCOM & B1rd & Bachman's sparrow & $\mathrm{C} 2$ & SE & B & Possible & $\mathrm{N}$ \\
\hline Fort & Campbe11 & FORSCOM & Mamma 1 & Raf1nesque's b1g-eared bat & C2 & ST & YR & Possible & $\mathbf{R}$ \\
\hline Fort & Campbel1 & FORSCOM & Mamma 1 & Southeastern bat & C2 & & E & Possible & $\mathbf{R}$ \\
\hline Fort & Campbel1 & FORSCOM & Amphiblan & Hellbender & C2 & & YR & Possible & $\mathrm{N}$ \\
\hline Fort & Campbel1 & FORSCOM & Fish & Lake sturgeon & C2 & SE & Adjacent & Possible & $\mathrm{N}$ \\
\hline Fort & Campbe11 & FORSCOM & Mammal & Eastern cougar & $\mathrm{FE}$ & & YR & Possible & HR \\
\hline Fort & Campbe11 & FORSCOM & B1rd & Interior least tern & FE & & $T$ & Possible & $\mathrm{R}$ \\
\hline Fort & Campbe11 & FORSCOM & Mollusk & Rough pigtoe & FE & & YR & Possible & NH \\
\hline Fort & Campbel1 & FORSCOM & Bird & Bachman's warbler & FE & & B & Ext1rpated & HR \\
\hline Fort & Campbe11 & FORSCOM & Mamma 1 & Red wolf & FE & & YR & Ext1rpated & HR \\
\hline Fort & Campbel1 & FORSCOM & Mamma 1 & Indiana bat & FE & & $B, F, M$ & Likely & $\mathrm{N}$ \\
\hline Fort & Campbel1 & FORSCOM & Mollusk & Tan riffleshell & FE & & YR & Unlikely & $\mathrm{NH}$ \\
\hline Fort & Campbel1 & FORSCOM & Mollusk & Golf-st1ck pearly mussel & FE & & YR & Unlikely & $\mathrm{NH}$ \\
\hline Fort & Campbel1 & FORSCOM & Mollusk & Dromedary pearly mussel & FE & & YR & Unl1kely & NH \\
\hline Fort & Campbel1 & FORSCOM & Mollusk & Orange-footed pearly mussel & FE & & YR & Possible & NH \\
\hline Fort & Campbel1 & FORSCOM & B1rd & Bald eagle & EE & & YR & Likely & $\mathrm{N}$ \\
\hline Fort & Campbel1 & FORSCOM & Mollusk & P1nk mucket pearly mussel & FE & & YR & Possible & $\mathrm{NH}$ \\
\hline Fort & Campbel1 & FORSCOM & B1rd & American peregrine falcon & FE & & I & Possible & $\mathbf{R}$ \\
\hline Fort & Campbel1 & FORSCOM & Mamma 1 & Gray bat & FE & & $\mathrm{F}$ & Likely & $\mathrm{N}$ \\
\hline Fort & Campbe 11 & FORSCOM & Mollusk & Yellow-blossom pearly mussel & FE & & YR & Possible & NH \\
\hline Fort & Campbeil & FORSCOM & Bird & Ivory-b1lled woodpecker & FE & & YR & Ext1rpated & HR \\
\hline Eort & Campbel1 & FORSCOM & B1rd & Arctic peregrine falcon & FT & & I & Possible & $\mathbf{R}$ \\
\hline Fort & Campbel1 & FORSCOM & B1rd & Piping plover & FT & & T & Possible & $\mathbf{R}$ \\
\hline Fort & Campbe11 & EORSCOM & Mollusk & Eastern fanshell & PE & & YR & Possible & NH \\
\hline Fort & Campbel1 & FORSCOM & Mollusk & Purple catspaw pearly mussel & PE & & YR & Possible & NH \\
\hline Fort & Campbe11 & FORSCOM & Bird & Upland sandpiper & SE & & $\mathrm{T}$ & Possible & $\mathrm{R}$ \\
\hline Fort & Campbel1 & FORSCOM & Bird & American bittern & SE & & YR & Possible & $\mathbf{R}$ \\
\hline Fort & Campbe11 & FORSCOM & B1rd & Blue-winged teal & SE & & M & Possible & $\mathbf{R}$ \\
\hline Fort & Campbel1 & FORSCOM & Bird & Common moorhen & SE & & B & Possible & $\mathrm{R}$ \\
\hline Fort & Campbel1 & FORSCOM & B1rd & K1ng ra11 & SE & & YR & Possible & $\mathbf{R}$ \\
\hline Fort & Campbel1. & FORSCOM & B1rd & Barn ow 1 & SE & & YR & Possible & $\mathrm{R}$ \\
\hline Fort & Campbe11 & FORSCOM & B1rd & Lark sparrow & SE & & B & Possible & $\mathrm{N}$ \\
\hline Fort & Campbel1 & FORSCOM & Bird & Spotted sandplper & SE & & YR & Possible & $\mathrm{N}$ \\
\hline Fort & Campbe 11 & FORSCOM & B1rd & Least bittern & SE & & $\mathrm{T}$ & Possible & $\mathrm{N}$ \\
\hline Eort & Campbe 11 & FORSCOM & Bird & V1rginia ra11 & SE & & M & Possible & $\mathbf{R}$ \\
\hline Fort & Campbe11 & FORSCOM & B1rd & Little blue heron & SE & & PB, F & Possible & $\mathrm{N}$ \\
\hline Eort & Campbe 11 & FORSCOM & B1rd & Sharp-shinned hawk & SE & & YR & Possible & $\mathrm{N}$ \\
\hline Fort & Campbel1 & FORSCOM & B1rd & Osprey & SE & & $\mathrm{M}$ & Possible & $\mathrm{N}$ \\
\hline Fort & Campbe11 & FORSCOM & Bird & Golden eagle & SE & & W & Possible & $\mathbf{R}$ \\
\hline Fort & Campbel1 & FORSCOM & B1rd & Grasshopper sparrow & SE & & B & Possible & $\mathrm{N}$ \\
\hline Fort & Campbel1 & FORSCOM & B1rd & Great egret & SE & & $B, P B$ & Possible & $\mathrm{N}$ \\
\hline Fort & Campbe11 & FORSCOM & B1rd & Double-crested cormorant & SE & & w & Possible & R \\
\hline
\end{tabular}




\section{Appendix A (continued)}

\begin{tabular}{|c|c|c|c|c|c|c|c|c|}
\hline Inst: & allation & MACOM & Taxon & Species & Status & Residency & \multicolumn{2}{|c|}{ Occurrance } \\
\hline Fort & Campbel1 & $\begin{array}{l}\text { FORSCOM } \\
\text { FORSCOM }\end{array}$ & B1rd & Hooded merganser & $\begin{array}{l}S E \\
S E\end{array}$ & $\begin{array}{l}Y R \\
B\end{array}$ & $\begin{array}{l}\text { Possible } \\
\text { Possible }\end{array}$ & $\begin{array}{l}\mathrm{N} \\
\mathrm{R}\end{array}$ \\
\hline $\begin{array}{l}\text { Fort } \\
\text { Fort }\end{array}$ & $\begin{array}{l}\text { Campbel1 } \\
\text { Campbell }\end{array}$ & FORSCOM & $\begin{array}{l}\text { Mammal } \\
\text { Fish }\end{array}$ & Smallscale darter & $S E$ & $Y R$ & $\begin{array}{l}\text { Possible } \\
\text { Possible }\end{array}$ & $\begin{array}{l}\mathrm{R} \\
\mathrm{N}\end{array}$ \\
\hline Fort & Campbe 11 & FORSCOM & B1rd & Cooper's hawk & SE & YR & Possible & $\mathrm{N}$ \\
\hline Fort & Campbel1 & FORSCOM & Bird & Black-crowned night heron & SE & $\mathrm{PB}, \mathrm{F}$ & Possible & $\mathrm{N}$ \\
\hline Fort & Campbel1 & FORSCOM & Fish & Slender madtom & SE & YR & Possible & $\mathrm{N}$ \\
\hline Fort & Campbel1 & FORSCOM & B1rd & Pled-billed grebe & SE & YR & Possible & $\mathrm{R}$ \\
\hline Fort & Campbell & FORSCOM & Bird & American coot & SE & W & Possible & $\mathrm{N}$ \\
\hline Fort & Campbe11 & FORSCOM & B1rd & Yellow-crowned night heron & ST & $\mathrm{PB}, \mathrm{F}$ & Possible & $\mathrm{N}$ \\
\hline Fort & Campbe 11 & FORSCOM & Bird & Northern harrier & ST & W & Possible & $\mathrm{N}$ \\
\hline Fort & Campbell & FORSCOM & Reptile & Western pygmy rattlesnake & ST & YR & Possible & $\mathrm{R}$ \\
\hline Fort & Campbell & FORSCOM & Amph 1 blan & B1rd-volced tree frog & ST & YR & Possible & $\mathrm{R}$ \\
\hline Fort & Campbell & FORSCOM & B1rd & Great blue heron & ST & YR & Possible & $\mathrm{R}$ \\
\hline Fort & Campbe 11 & FORSCOM & B1rd & Bank swallow & ST & B & Possible & $\mathrm{N}$ \\
\hline Fort & Campbe 11 & FORSCOM & Mamma 1 & River otter & ST & YR & Possible & $\mathrm{R}$ \\
\hline Fort & Devens & FORSCOM & Mamna 1 & New England cottontall & $\mathrm{C} 2$ & YR & Possible & $\mathrm{R}$ \\
\hline Fort & Devens & FORSCOM & Mamma 1 & Eastern small-footed bat & $\mathrm{C} 2$ & $\mathrm{~F}, \mathrm{M}$ & Possible & R \\
\hline Eort & Devens & FORSCOM & Mamma 1 & Eastern cougar & $E E$ & YR & Extirpated & HR \\
\hline Fort & Devens & FORSCOM & B1rd & American peregrine falcon & $\mathrm{EE}$ & M & Possible & $\mathrm{R}$ \\
\hline Fort & Devens & FORSCOM & Mamma 1 & Indlana bat & $\mathrm{FE}$ & $\mathrm{F}, \mathrm{M}$ & Posstble & $\mathrm{R}$ \\
\hline Eort & Devens & FORSCOM & B1rd & Bald eagle & $\mathrm{FE}$ & $T$ & Possible & $\mathrm{N}$ \\
\hline Fort & Devens & FORSCOM & Bird & Arctic peregrine falcon & ET & $M$ & Possible & $\mathrm{R}$ \\
\hline Fort & Devens & FORSCOM & B1rd & Henslow's sparrow & SE & B & Possible & $\mathrm{R}$ \\
\hline Fort & Devens & FORSCOM & Bird. & Upland sandpiper & SE & B & Current & \\
\hline Fort & Devens & FORSCOM & B1rd & Pled-billed grebe & ST & B & Possible & $\mathrm{N}$ \\
\hline Fort & Devens & FORSCOM & Bird & Northern harrier & ST & $\mathrm{T}$ & Possible & $\mathrm{R}$ \\
\hline Fort & Devens & FORSCOM & Rept1le & Blandling's turtle & ST & YR & Possible & $\mathrm{N}$ \\
\hline Fort & Devens & FORSCOM & Amphibian & Marbled salamander & ST & YR & Possible & $\mathrm{R}$ \\
\hline Fort & Devens & FORSCOM & B1rd & Least b1ttern & ST & B & Possible & $\mathrm{N}$ \\
\hline Fort & D1 $x$ & TRADOC & Amphiblan & Pine barrens tree frog & $3 c$ & YR & Possible & $\mathrm{N}$ \\
\hline Fort & D1x & TRADOC & Insect & Lemmer's pinnion moth & $\mathrm{C} 2$ & & Possible & $\mathrm{R}$ \\
\hline Fort & D $1 x$ & TRADOC & Mamma 1 & Eastern small-footed bat & $\mathrm{C} 2$ & $\mathrm{~T}$ & Possible & HR \\
\hline Fort & $\mathrm{D} 1 \mathrm{x}$ & TRADOC & Reptile & Bog turtle & $\mathrm{c} 2$ & YR & Possible & $\mathrm{N}$ \\
\hline Fort & Dix & TRADOC & Insect & Daeke's pyralld moth & $\mathrm{C} 2$ & & Possible & $\mathrm{N}$ \\
\hline Fort & D1x & TRADOC & Mamma 1 & New England cottontall & $\mathrm{C} 2$ & YR & Possible & $\mathrm{R}$ \\
\hline Fort & $\mathrm{D} 1 \mathrm{x}$ & TRADOC & B1rd & Cooper's hawk & $\mathrm{C} 2$ & SE & Possible & $\mathrm{N}$ \\
\hline Fort & $D 1 x$ & TRADOC & Insect & Bucholzi's dart moth & $\mathrm{C} 2$ & & Possible & $\mathrm{N}$ \\
\hline Fort & D1x & TRADOC & B1rd & Mlgrant loggerhead shrike & $\mathrm{C} 2$ & SE & Possible & $\mathrm{N}$ \\
\hline Fort & $\mathrm{D} 1 \mathrm{x}$ & TRADOC & Reptile & Northern pine snake & $\mathrm{C} 2$ & YR & Possible & $\mathrm{N}$ \\
\hline Fort & $\mathrm{D} 1 \mathrm{x}$ & TRADOC & Insect & Barrens blue damselfly & $\mathrm{C} 2$ & & Possible & $\mathrm{N}$ \\
\hline Fort & D $1 x$ & TRADOC & Blrd & American peregrine falcon & FE & YR & Possible & $\mathrm{N}$ \\
\hline Eort. & $D 1 x$ & TRADOC & Mammal & Mounta1n lion & $\mathrm{FE}$ & YR & Ext1rpated & $\mathrm{HR}$ \\
\hline Fort & D1x & TRADOC & B1rd & Plplng plover & FT & $\mathrm{T}$ & Possible & $\mathrm{N}$ \\
\hline Fort & $\mathrm{D} 1 \mathrm{x}$ & TRADOC & Bird & Arct $1 \mathrm{c}$ peregrine falcon & $\mathrm{FT}$ & $\mathrm{M}$ & Possible & $\mathrm{R}$ \\
\hline Fort & $\mathrm{D} 1 \mathrm{x}$ & TRADOC & Bird & Short-eared ow 1 & SE & YR & Possible & $\ddot{R}$ \\
\hline Fort & $\mathrm{D} 1 \mathrm{x}$ & TRADOC & Bird & Upland sandplper & $\mathrm{SE}$ & B & Possible & $\mathrm{N}$ \\
\hline Eort & $D 1 x$ & TRADOC & Amphiblan & Eastern t1ger salamander & $S E$ & YR & Possible & $\mathrm{N}$ \\
\hline Fort & D $1 x$ & TRADOC & Bird & Cliff swallow & SE & M & Possible & $\mathrm{R}$ \\
\hline Fort & $\mathrm{D} 1 \mathrm{x}$ & TRADOC & Bird & Vesper sparrow & SE & YR & Possible & $\mathrm{N}$ \\
\hline Fort & $\mathrm{D} 1 \mathrm{x}$ & TRADOC & Reptile & Corn snake & SE & YR & Possible & $\mathrm{N}$ \\
\hline Fort & D1x & TRADOC & B1rd & Pled-b1lled grebe & SE & YR & Possible & $\mathrm{N}$ \\
\hline Fort & D1x & TRADOC & B1rd & Sedge wren & SE & B & Possible & $\mathrm{R}$ \\
\hline Fort & $D \perp x$ & TRADOC & B1rd & Eastern least tern & $S E$ & $\mathrm{~T}$ & Possible & $\mathrm{N}$ \\
\hline Fort & $D 1 x$ & TRADOC & Reptile & Timber rattlesnake & SE & YR & Possible & $\mathrm{N}$ \\
\hline Fort & $D 1 x$ & TRADOC & B1rd & Northern harrier & SE & YR & Possible & $\mathrm{N}$ \\
\hline Fort & $\mathrm{D} 1 \mathrm{x}$ & TRADOC & B1rd & Black rall & ST & B & Possible & $\mathrm{N}$ \\
\hline Fort & $\mathrm{D} 1 \mathrm{x}$ & TRADOC & Amphiblan & Mud salamander & ST & YR & Possible & $\mathrm{R}$ \\
\hline Fort & $\mathrm{D} 1 \mathrm{x}$ & TRADOC & Fish & Brook trout & ST & YR & Possible & $\mathrm{R}$ \\
\hline Fort & D1x & TRADOC & Bird & American bittern & ST & B & Possible & $\mathrm{R}$ \\
\hline Fort & Dix & TRADOC & B1rd & Grasshopper sparrow & ST & B & Possible & $\mathrm{N}$ \\
\hline Fort & D1x & TRADOC & B1rd & Northern goshawk & ST & T & Possible & $\mathrm{R}$ \\
\hline Fort & Dix & TRADOC & B1rd & Red-shouldered hawk & ST & W & Possible & $\mathrm{N}$ \\
\hline Fort & $\mathrm{D} 1 \mathrm{x}$ & TRADOC & B1rd & Great blue heron & ST & YR & Possible & $\mathrm{N}$ \\
\hline Fort & $D 1 x$ & TRADOC & B1rd & Yellow-crowned night heron & ST & B & Possible & $\mathrm{N}$ \\
\hline Fort & $D \perp x$ & TRADOC & B1rd & Barred ow 1 & ST & YR & Possible & $\mathrm{N}$ \\
\hline Fort & D $1 x$ & TRADOC & B1rd & Savannah sparrow & ST & YR & Possible & $\mathrm{N}$ \\
\hline Fort & $\mathrm{D} 1 \mathrm{x}$ & TRADOC & B1rd & Red-headed woodpecker & ST & YR & Possible & $\mathrm{N}$ \\
\hline Fort & $D \perp x$ & TRADOC & B1rd & Bobolink & ST & M & Possible & R \\
\hline Fort & DIx & TRADOC & Rept 11 e & Wood turtle & ST & YR & Possible & $\mathrm{N}$ \\
\hline Fort & $D \perp x$ & TRADOC & Blrd & Osprey & ST & B & Possible & $\mathrm{N}$ \\
\hline Fort & Drum & FORSCOM & Bird & American peregrine falcon & FE & $M *$ & Possible & R \\
\hline Fort & Drum & FORSCOM & Mammal & Indiana bat & FE & E, M & Possible & $\mathrm{R}$ \\
\hline Fort & Drum & FORSCOM & Mamma 1 & Mountain lion & FE & YR & Ext1rpated & HR \\
\hline Fort & Drum & FORSCOM & B1rd & Bald eagle & FE & M & Possible & $\mathrm{R}$ \\
\hline Fort & Drum & FORSCOM & Bird & Arctic peregrine falcon & FT & M & Possible & $\mathrm{R}$. \\
\hline Fort & Drum & FORSCOM & Bird & Golden eagle & SE & M & Possible & $\mathrm{R}$ \\
\hline Fort & Drum & FORSCOM & Bird & Common tern & ST & $M$ & Possible & $\mathrm{R}$ \\
\hline Fort & Drum & FORSCOM & B1rd & Osprey & ST & M & Possible & $\mathrm{R}$ \\
\hline Fort & Drum & FORSCOM & B1rd & Northern harrier & ST & B & Possible & $\mathrm{R}$ \\
\hline Fort & Drum & FORSCOM & Bird & Red-shouldered hawk & ST & B & Possible & $\mathrm{R}$ \\
\hline Fort & Eust 1 s & TRADOC & B1rd & Bachman's warbler & FE & M & Ext1rpated & \\
\hline Fort & Eust is & TRADOC & Bird & Bald eagle & $\mathrm{FE}$ & B & Current & \\
\hline Fort & Eust 1s & TRADOC & B1rd & American peregrine falcon & FE & B & Possible & $\mathrm{N}$ \\
\hline Fort & Eustis & TRADOC & Rept1le & Atlantic loggerhead turtie & FT & Adfacent & Possible & $\mathrm{R}$ \\
\hline Fort & Eustis & TRADOC & Bird & Arctic peregrine falcon & ET & $\mathrm{M}$ & Possible & $\mathrm{R}$ \\
\hline Fort & Eust 1s & TRADOC & Bird & Plping plover & FT & $\mathrm{T}$ & Possible & $\mathrm{N}$ \\
\hline
\end{tabular}


Appendix A (continued)

\begin{tabular}{|c|c|c|c|}
\hline Inst & allation & & \\
\hline Fort & Eustis & & \\
\hline Fort & Eustis & & \\
\hline Fort & Eust1s & & \\
\hline Fort & Eustis & & \\
\hline Fort & Eustis & & \\
\hline Fort & Eust 1s & & \\
\hline Fort & Eustis & & \\
\hline Fort & George & Meade & \\
\hline Fort & George & Meade & \\
\hline Fort & George & Meade & \\
\hline Fort & George & Meade & \\
\hline Fort & George & Meade & \\
\hline Fort & George & Meade & \\
\hline Fort & George & Meade & \\
\hline Fort & George & Meade & \\
\hline Fort & Gordon & & \\
\hline Fort & Gordon & & \\
\hline Fort & Gordon & & \\
\hline Fort & Gordon & & \\
\hline Fort & Gordon & & \\
\hline Fort & Gordon & & \\
\hline Fort & Gordon & & \\
\hline Fort & Gordon & & \\
\hline Fort & Gordon & & \\
\hline Fort & Gordon & & \\
\hline Fort & Gordon & & \\
\hline Fort & Gordon & & \\
\hline Eort & Gordon & & \\
\hline Fort & Gordon & . & \\
\hline Fort & Indlanto & Eown & Gap \\
\hline Fort & Indianto & town & Gap \\
\hline Fort & Indlante & town & Gap \\
\hline Fort & Indlanto & town & Gap \\
\hline Fort & Indianto & Eown & Gap \\
\hline Fort & Indianto & town & Gap \\
\hline Fort & Indianto & Eown & Gap \\
\hline Fort & Indlanto & town & Gap \\
\hline Fort & Jackson & & \\
\hline Fort & Jackson & & \\
\hline Fort & Jackson & & \\
\hline Fort & Jackson & & \\
\hline Fort & Jackson & & \\
\hline Fort & Jackson & & \\
\hline Fort & Jackson & & \\
\hline Fort & Jackson & & \\
\hline Fort & Jackson & & \\
\hline Fort & Jackson & & \\
\hline Fort & Jackson & & \\
\hline Fort & Jackson & & \\
\hline Fort & Jackson & & \\
\hline Fort & Jackson & & \\
\hline Fort & Jackson & & \\
\hline Fort & Knox & & \\
\hline Fort & Knox & & \\
\hline Fort & Knox & & \\
\hline Fort & Knox & & \\
\hline Fort & Knox & & \\
\hline Fort & Knox & & \\
\hline Fort & Knox & & \\
\hline Eort & Knox & & \\
\hline Fort & Knox & & \\
\hline Fort & Knox & & \\
\hline Fort & Knox & & \\
\hline Fort & Knox & & \\
\hline Eort & Knox & & \\
\hline Fort & Knox & & \\
\hline Fort & Knox & & \\
\hline Fort & Knox & & \\
\hline Fort & Knox & & \\
\hline Fort & Knox & & \\
\hline Eort & Knox & & \\
\hline Fort & Knox & & \\
\hline Fort & Knox & & \\
\hline Eort & Knox & & \\
\hline Fort & Knox & & \\
\hline Fort & Knox & & \\
\hline Fort & Knox & & \\
\hline Fort & Knox & & \\
\hline Fort & Knox & & \\
\hline Fort & Knox & & \\
\hline Fort & Knox & & \\
\hline Fort & Knox & & . \\
\hline Eort & Knox & & \\
\hline Fort & Knox & & \\
\hline Fort & Knox & & \\
\hline & Knox & & \\
\hline
\end{tabular}

MACOM Taxon

TRADOC

TRADOC

TRADOC

TRADOC

TRADOC

FORSCOM

FORSCOM

FORSCOM

FORSCOM

EORSCOM

FORSCOM

FORSCOM

TRADOC

TRADOC

TRADOC

TRADOC

TRADOC

TRADOC

TRADOC

TRADOC

TRADOC

TRADOC

TRADOC

TRADOC

FORSCOM

FORSCOM

FORSCOM

FORSCOM

FORSCOM

FORSCOM

FORSCOM

FORSCOM

TRADOC

TRADOC

TRADOC

TRADOC

TRADOC

TRADOC

TRADOC

TRADOC

TRADOC

TRADOC

TRADOC

TRADOC

TRADOC

TRADOC

TRADOC

TRADOC

TRADOC

TRADOC

TRADOC

TRADOC

TRADOC

TRADOC

TRADOC

TRADOC

TRADOC

TRADOC

TRADOC

TRADOC

TRADOC

TRADOC

TRADOC

TRADOC

TRADOC

TRADOC

TRADOC

TRADOC

TRADOC

TRADOC

TRADOC

TRADOC

TRADOC

TRADOC

TRADOC

\section{Bird}

Reptlle

B1rd

Bird

Bird

Mamma 1

B1rd

Marma 1

Bird

Bird

BIrd

Bird

Bird

Rept1le

Mamma I

Mamma 1

Mamma 1

Mamma

Bird.

Bird

Bird

Reptile

Rept11e

Insect

Rept1le

Insect

Insect

Bird

Bird

Bird

Mammal

B1rd

Bird

Bird

B1rd

B1rd

Mamma 1

Mamma 1

B1rd

Rept1le

Bird

Bird

Mollusk

B1rd

Mamma 1

Mollus

Reptile

Mamma 1

Fish

Mollusk

Mammal

Mollusk

Mamma 1

Mollusk

Mollusk

Mollus

Bird

Mamma 1

B1rd

Mollusk

Mammal

Mollus

Bird

Mamma

Mollus

Mamma 1

Mollusk

Mollusk

Mollusk

Bird

\section{Species}

Sedge wren

Eastern least tern

Canebrake rattlesnake

Northern harrier

Gull-bllled tern

wellow-crowned night heron

Eastern small-footed bat

Bachman's sparrow

Southern pygmy shrew

Migrant loggerhead shrike

Bald eagle

Kirtland's warbler

American peregrine falcon

Arctic peregrine falcon

Appalachian Bew1ck's wren

Gopher tortolse

American peregrine falcon

Florida panther

Red wolf

Eastern couga

Indiana bat

Bald eagle

Ivory-billed woodpecker

Wood stork

Red-cockaded woodpecker

Arctic peregrine falcon

Eastern Indigo snake

American alligator

(Classifled)

Bog turtle

Tawny crescent

Sugar maple longhorn beetle

Indlana bat

Arctic peregrine falcon

Upland sandplper

Grasshopper sparrow

Appalachian Bewick's wren

Rafinesque's big-eared bat

Red wolf

Bachman's warbler

Wood stork

Red-cockaded woodpecke

American peregrine falcon

Kirtland's warbler

Bald eagle

Ivory-billed woodpecker

Eastern cougar

Florida panther

Arctic peregrine falcon

American alligator

Golden eagle

Appalachlan Bewlck's wren

Northern cavef 1 sh

Loulsville crayfish

Bachman's sparrow

Eastern woodrat

Bean villosa

Blue sucker

Copperbelly water snake

Southeastern bat

Eastern sand darter

Purple 11111put

Rafinesque's big-eared bat

Ortmann's pearly mussel.

Eastern small-footed bat

Salamander mussel

Hellbender

Onyx rocksnall

Rough rabblt's foot

Mlgrant loggerhead shrike

Southern pygmy shrew

Ivory-bllled woodpecker

P1nk mucket pearly mussel

Red wolf

Rough pigtoe

American peregrine falcon

Gray bat

Interfor least tern

Cracking pearly mussel

Eastern cougar

Ring pink

Bald eagle

Fat pocketbook

Orange-footed pearly mussel

Arctic peregrine falcon

\section{Status Residency Occurrance}

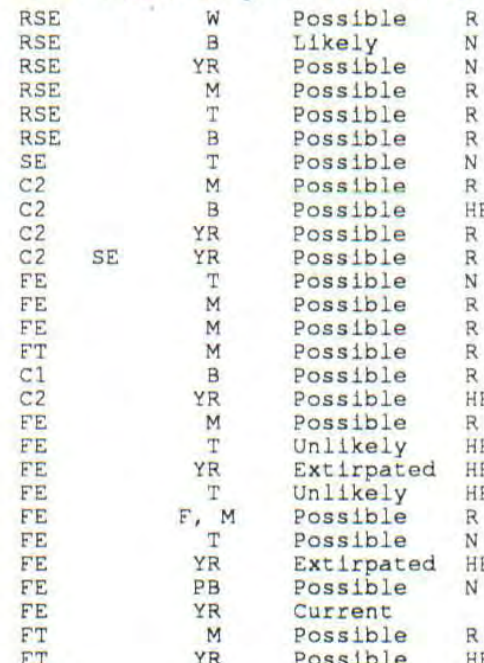

Possible

current

Likely N

Possible

Possible

Possible

Possible

Possible

Possible

Possible

Extirpated $R$

Extirpated HR

Extirpated HR

Current

possible

possible

Possible

Ext1rpated HR

Extirpated HR

Ext1rpated HR

Possible

Possible

Possible

Possible

Possible

Current

Possible

Possible

Possible

Possible

Possible

Possible

Possible

possible

Possible

Possible

Possible

Possible

R

Possible $\mathrm{NH}$

Extirpated ${ }^{H R}$

Possible N

Ext1rpated HR

Extirpated HR

Extirpated HR

Possible $R$

Possible 


\section{Appendix A (continued)}

\begin{tabular}{|c|c|c|c|c|c|c|c|c|c|}
\hline \multicolumn{2}{|c|}{ Installation } & MACOM & Taxon & Species & Status & $\mathbf{R e}$ & idency & Occurrance & \\
\hline Fort & Knox & TRADOC & B1rd & Piplng plover & FT & & B & Possible & $\mathrm{N}$ \\
\hline Fort & Knox & TRADOC & Mollusk & Eastern fanshell & PE & ST & YR & Possible & $\mathrm{NH}$ \\
\hline Fort & Knox & TRADOC & B1rd & Double-crested cormorant & SE & & I & Possible & $\mathrm{R}$ \\
\hline Eort & Knox & TRADOC & Blrd & Little blue heron & SE & & T & Possible & $\mathrm{N}$ \\
\hline Fort & Knox & TRADOC & B1rd & American blttern & SE & & $\mathrm{T}$ & Possible & $\mathrm{N}$ \\
\hline Fort & Knox & TRADOC & B1rd & Great egret & $\mathrm{SE}$ & & & Possible & R \\
\hline Fort & knox & TRADOC & B1rd & King rail & $\mathrm{SE}$ & & B & Possible & $\mathrm{N}$ \\
\hline Fort & Knox & TRADOC & B1rd & Spotted Sandpiper & $\mathrm{SE}$ & & B & Possible & $\mathrm{R}$ \\
\hline Fort & knox & TRADOC & Bird & Pled-bllled grebe & $\mathrm{SE}$ & & W & Possible & $\mathrm{R}$ \\
\hline Fort & Knox & TRADOC & B1rd & Lark sparrow & $S E$ & & B & Possible & $\mathrm{R}$ \\
\hline Fort & Knox & TRADOC & Rept1le & K1rtland's snake & SE & & YR & Possible & $\mathrm{N}$ \\
\hline Fort & Knox & TRADOC & Blrd & Upland sandplper & SE & & M & Possible & $\mathrm{R}$ \\
\hline Fort & Knox & TRADOC & Bird & Least bittern & $\mathrm{SE}$ & & B & Possible & $\mathrm{N}$ \\
\hline Fort & Knox & TRADOC & Bird & American coot & $\mathrm{SE}$ & & T & Possible & $\mathrm{N}$ \\
\hline Fort & Knox & TRADOC & B1rd & Hooded merganser & SE & & w & Possible & $\mathrm{R}$ \\
\hline Fort & Knox & TRADOC & Bird & Blue-winged teal & SE & & T & Possible & $\mathrm{R}$ \\
\hline Fort & Knox & TRADOC & Bird & Black-crowned night heron & SE & & B & Possible & $\mathrm{N}$ \\
\hline Fort & Knox & TRADOC & Blrd & Blackburnian warbler & SE & & T & Possible & $\mathrm{R}$ \\
\hline Fort & Knox & TRADOC & Bird. & Osprey & $\mathrm{SE}$ & & M & Possible & $\mathrm{R}$ \\
\hline Fort & knox & TRADOC & B1rd & Common moorhen & SE & & $\mathrm{T}$ & Possible & $\mathrm{N}$ \\
\hline Fort & Knox & TRADOC & Mamma 1 & Evening bat & ST & & B & Possible & $\mathrm{R}$ \\
\hline Fort & Knox & TRADOC & Bird & Yellow-crowned night heron & ST & & B & Possible & $\mathrm{N}$ \\
\hline Fort & Lee & TRADOC & Bird & Migrant Loggerhead shrike & $\mathrm{C2}$ & SE & B. & Possible & $\mathrm{N}$ \\
\hline Fort & Lee & TRADOC & B1rd & Bachman's warbler & $\mathrm{FE}$ & & M & Extlrpated & HR \\
\hline Fort & Lee & TRADOC & B1rd & American peregrine falcon & $\mathrm{FE}$ & & T & Possible & $\mathrm{R}$ \\
\hline Fort & Lee & TRADOC & Bird & Bald eagle & $\mathrm{FE}$ & & B & Current & \\
\hline Fort & Lee & TRADOC & B1rd & Yellow-crowned night heron & RSE & & B & Possible & $\mathrm{R}$ \\
\hline Fort & Lee & TRADOC & B1rd & Northern harrier & RSE & & T & Possible & $\mathrm{R}$ \\
\hline Fort & Lee & TRADOC & Bird & Henslow's sparrow & RSE & & B & Possible & $\mathrm{R}$ \\
\hline Fort & Lee & TRADOC & Fish & Blackbanded sunfish & $\mathrm{SE}$ & & YR & Current & \\
\hline Fort & McClellan & TRADOC & B1rd. & Appalachlan Bewick's wren & $\mathrm{Cl}$ & ST & YR & Possible & $\mathrm{R}$ \\
\hline Fort & Mcclellan & TRADOC & Mollusk & sculpin snail & $\mathrm{C} 2$ & & YR & Possible & $\mathrm{N}$ \\
\hline Fort & Mcclellan & TRADOC & Mollusk & Fine-1ined pocketbook & $\mathrm{C} 2$ & & YR & Possible & $\mathrm{NH}$ \\
\hline Fort & Mcclellan & TRADOC & Mollusk & Alabama live-bearing sna11 & $\mathrm{C} 2$ & & $Y R$ & Possible & \\
\hline Fort & Mcclellan & TRADOC & Mollusk & Purple liliput & $\mathrm{C} 2$ & & YR & Possible & $\mathrm{NH}$ \\
\hline Fort & Mcclellan & TRADOC & Fish & Coldwater darter & $\mathrm{C} 2$ & & YR & Possible & $\mathrm{N}$ \\
\hline Fort & Mcclellan & TRADOC & F1sh & Blue shiner & $\mathrm{c} 2$ & & YR & Possible & $\mathrm{N}$ \\
\hline Fort & Mcclellan & TRADOC & Mollusk & Tennessee heelsplitter & $c 2$ & & YR & Possible & $\mathrm{NH}$ \\
\hline Fort & Mcclelian & TRADOC & Mollusk & Upland combsheli & C2 & & YR & Possible & $\mathrm{NH}$ \\
\hline Fort & Mcclellan & TRADOC & B1rd & Bachman's warbler & $\mathrm{FE}$ & & $\mathrm{T}$ & Ext1rpated & $H R$ \\
\hline Fort & Mcclellan & TRADOC & B1rd & American peregrine falcon & $\mathrm{FE}$ & & M & Unlikely & $\mathrm{R}$ \\
\hline Fort & Mcclellan & TRADOC & Mamma 1 & Florida panther & $\mathrm{FE}$ & & YR & Ext1rpated & HR \\
\hline Fort & Mcclellan & TRADOC & Mammal & Red wolf & $\mathrm{FE}$ & & YR & Extirpated & $H R$ \\
\hline Fort & Mcclellan & TRADOC & Bird & Red-cockaded woodpecker & FE & & YR & Possible & $\mathrm{N}$ \\
\hline Fort & Mcclellan & TRADOC & Mamma 1 & Gray bat & $\mathrm{FE}$ & & $\mathrm{T}$ & Possible & R \\
\hline Fort & Meclellan & TRADOC & B1rd & Bald eagle & $\mathrm{FE}$ & & $\mathrm{F}$ & Possible & \\
\hline Fort & Meclellan & TRADOC & Mamma 1 & Indiana bat & $\mathrm{FE}$ & & $B, F, M$ & Possible & $\ddot{R}$ \\
\hline Fort & Mcclellan & TRADOC & Mollusk & Judge Tait's musse 1 & FE & & YR & Possible & $\mathrm{NH}$ \\
\hline Fort & McClellan & TRADOC & B1rd & Arctic Peregrine falcon & FT & & M & Unlikely & $\mathrm{R}$ \\
\hline Fort & Mcclellan & TRADOC & Fish & Pygmy sculpin & FT & & YR & Possible & $\mathrm{N}$ \\
\hline $\begin{array}{l}\text { Eort } \\
\text { Fort }\end{array}$ & Mecoy & FORSCOM & Insect & Karner blue butterfly & $\mathrm{C} 2$ & & & Current & \\
\hline Fort & MeCoy & FORSCOM & Reptile & Eastern massasauga & $\mathrm{C} 2$ & SE & YR & Possible & $\mathrm{N}$ \\
\hline Fort & MeCoy & FORSCOM & Bird & Migrant loggerhead shrike & $\mathrm{c} 2$ & $\mathrm{SE}$ & B & Possible & $\mathrm{N}$ \\
\hline Fort & McCoy & FORSCOM & B1rd & Plping plover & $\mathrm{FE}$ & & M & Possible & $\mathrm{N}$ \\
\hline Fort & McCoy & FORSCOM & Insect & Glant carrion beet le & FE & & & Possible & $\mathrm{NH}$ \\
\hline Fort & McCoy & FORSCOM & Bird & American peregrine falcon & FE & & M & Current. & \\
\hline Fort & MeCoy & FORSCOM & B1rd & Bald eagle & FT & & M & Current & \\
\hline Fort & MeCoy. & FORSCOM & B1rd & Arctic peregrine falcon & FT & & M & Possible & $\mathrm{R}$ \\
\hline Fort & MeCoy & FORSCOM & Bird & Casplan tern & SE & & M & Current & \\
\hline Fort & MeCoy & EORSCOM & Rept1le & Western slender glass 11zard & SE & & YR & Current & \\
\hline Fort & MeCoy & FORSCOM & B1rd & Yellow-throated warbler & SE & & M & Possible & \\
\hline Fort & McCoy & FORSCOM & Amph 1 blan & Blanchard's cricket frog & SE & & YR & Current & \\
\hline Fort & MeCoy & FORSCOM & B1rd & Osprey & SE & & SR & Current & \\
\hline Fort & McCoy & FORSCOM & B1rd & Red-necked grebe & SE & & M & Possible & $\mathbf{R}$ \\
\hline Fort & McCoy & FORSCOM & Rept1le & Wood turtle & ST & & YR & Current & \\
\hline Fort & McCoy & FORSCOM & Fish & Redfin shiner & ST & & YR & Possible & $\mathrm{N}$ \\
\hline Fort & McCoy & FORSCOM & B1rd & Acadian flycatcher & ST & & M & Possible & $\mathrm{N}$ \\
\hline Fort & McCoy & FOR & B1rd & s vireo & ST & & T & Possible & $\mathrm{R}$ \\
\hline Fort & McCoy & FORSCOM & Bird & Kentucky warbler & ST & & $\mathrm{M}$ & Current & \\
\hline Fort & McCoy & FORSCOM & Bird & Great egret & ST & & B & Possible & $\mathrm{N}$ \\
\hline Fort & MeCoy & FORSCOM & Blrd & Red-shouldered hawk & ST & & B & Possible & $\mathrm{N}$ \\
\hline Fort & MeCoy & FORSCOM & F1sh & Gilt darter & ST & & $\mathrm{YR}$ & Possible & $\mathrm{N}$ \\
\hline Fort & MeCoy & FORSCOM & Fish & R1ver redhorse & ST & & YR & Possible & $\mathrm{N}$ \\
\hline Fort & McCoy & FORSCOM & B1rd & Cerulean warbler & ST & & B & Possible & $\mathrm{N}$ \\
\hline Fort & McCoy & FORSCOM & Rept1le & Blanding's turtle & ST & & YR & Current & \\
\hline Fort & P1ckett & FORSCOM & Blrd & Migrant loggerhead shrike & $\mathrm{C} 2$ & SE & B & Possible & $\mathrm{R}$ \\
\hline Eort & pickett & FORSCOM & B1 & American peregrine falcon & $\mathrm{FE}$ & & M & Possible & $\mathrm{R}$ \\
\hline Fort & Pickett & FORSCOM & Mollusk & Dwarf wedge mussel & $\mathrm{FE}$ & & YR & Possible & $\mathrm{N}$ \\
\hline Fort & Pickett & FORSCOM & B1rd & Bachman's warbler & $\mathrm{FE}$ & & M & Ext1rpated & $\mathrm{HR}$ \\
\hline Fort & P1ckett & FORSCOM & Bird & Henslow's sparrow & RSE & & B & Possible & $\mathrm{R}$ \\
\hline Fort & Plckett & FORSCOM & B1rd & Northern harrier & RSE & & M & Possible & $\mathrm{R}$ \\
\hline Fort & Rucker & TRADOC & Bird & Appalachlan Bewick's wren & $\mathrm{Cl}$ & ST & M & Unlikely & $\mathrm{R}$ \\
\hline Fort & Rucker & TRADOC & Mollusk & Southern sandshell & $\mathrm{c} 2$ & & YR & Possible & HR \\
\hline Fort & Rucker & TRADOC & Mollusk & Choctaw bean & $\mathrm{c} 2$ & & YR & Possible & \\
\hline Fort & Rucker & TRADOC & Mollusk & Southern k1dneyshell & $\mathrm{c} 2$ & & YR & Possible & \\
\hline Fort & Rucker & TRADOC & Reptile & Gopher tortolse & C2 & ST & YR & Ext1rpated & \\
\hline
\end{tabular}


Appendix A (continued)

\begin{tabular}{|c|c|c|c|c|c|c|c|c|}
\hline Installation & MACOM & Taxon & Species & Status & & Residency & Occurranc & \\
\hline $\begin{array}{l}\text { Eort Rucker } \\
\text { Fort Rucker }\end{array}$ & $\begin{array}{l}\text { TRADOC } \\
\text { TRADOC }\end{array}$ & $\begin{array}{l}\text { B1rd } \\
\text { B1rd }\end{array}$ & $\begin{array}{l}\text { Ivory-billed woodpecker } \\
\text { Amerlcan peregrine falcon }\end{array}$ & $F E$ & & YR & Extirpated & $H R$ \\
\hline Fort Rucker & TRADOC & $\begin{array}{l}\text { B1rd } \\
\text { Mammal }\end{array}$ & $\begin{array}{l}\text { American peregrine falcon } \\
\text { Florida panther }\end{array}$ & $\begin{array}{l}F E \\
F E\end{array}$ & & $Y_{R}^{T}$ & Possible & $\mathrm{R}$ \\
\hline Fort Rucker & TRADOC & Mamma 1 & Red wolf & $\mathrm{FE}$ & & YR & $\begin{array}{l}\text { Extirpated } \\
\text { Extirpated }\end{array}$ & $\begin{array}{l}\mathrm{HR} \\
\mathrm{HR}\end{array}$ \\
\hline Eort Rucker & TRADOC & Bird & Red-cockaded woodpecker & FE & & YR & Unlikely. & $\mathrm{R}$ \\
\hline Eort Rucker & TRADOC & Mamma 1 & Indiana bat & FE & & $B, F$ & Possible & N \\
\hline Fort Rucker & TRADOC & B1rd & Bald eagle & $\mathrm{FE}$ & & E & Possible & $\mathrm{N}$ \\
\hline Fort Rucker & TRADOC & B1rd & Bachman's warbler & $\mathrm{FE}$ & & B & Extirpated & \\
\hline Fort Rucker & TRADOC & Bird & Wood stork & EE & & $\mathrm{PB}$ & Possible & $\mathrm{N}$ \\
\hline Fort Rucker & TRADOC & B1rd & Arctic peregrine falcon & FT & & $\mathrm{T}$ & Possible & $\mathrm{R}$ \\
\hline Fort Rucker & TRADOC & Rept1le & Eastern Indigo snake & ET & & YR & Ext1rpated & $\mathrm{HR}$ \\
\hline Fort Stewart & FORSCOM & Mamma 1 & Sherman's pocket gopher & $3 \mathrm{~A}$ & SE & YR & Possible & HR \\
\hline Fort Stewart & FORSCOM & B1rd & Appalachian Bewlck's wren & C1 & & M & Possible & $\mathrm{R}$ \\
\hline Fort Stewart & FORSCOM & Reptile & Gopher tortolse & $\mathrm{C} 2$ & & YR & Current & \\
\hline Fort Stewart & FORSCOM & B1rd & Red-cockaded woodpecker & $\mathrm{FE}$ & & YR & Current & \\
\hline Stewart & FORSCOM & Mamma 1 & Eastern cougar & $\mathrm{FE}$ & & $T$ & Possible & HR \\
\hline Stewart & FORSCOM & B1rd & Kirtland's warbler & $\mathrm{FE}$ & & M & Possible & $\mathrm{R}$ \\
\hline Stewart & FORSCOM & B1rd & Ivory-bllled woodpecker & FE & & YR & Ext1rpated & HR \\
\hline Stewart & FORSCOM & B1rd. & American peregrine falcon & $\mathrm{FE}$ & & M & Possible & $\mathrm{R}$ \\
\hline Fort Stewart & FORSCOM & B1rd & Bachman's warbler & $\mathrm{FE}$ & & B & Extirpated & $\mathrm{R}$ \\
\hline Stewart & FORSCOM & Mamma 1 & Florlda panther & FE & & I & Possible & HR \\
\hline Stewart & FORSCOM & Bird & Bald eagle & $\mathrm{FE}$ & & w & Likely & $\mathrm{N}$ \\
\hline Stewart & FORSCOM & B1rd & Wood stork & $\mathrm{FE}$ & & PB. & Possible & $\mathrm{N}$ \\
\hline Stewart & FORSCOM & Mamma 1 & West Indian manatee & FE & & Adjacent & Possible & $\mathrm{R}$ \\
\hline Fort Stewart & FORSCOM & Mamma 1 & Red wolf & $\mathrm{FE}$ & & YR & Extirpated & $\mathrm{HR}$ \\
\hline Fort Stewart & FORSCOM & Reptile & Kemp's ridley sea turtle & $\mathrm{FE}$ & & Adjacent & Possible & $\mathrm{R}$ \\
\hline Fort stewart & FORSCOM & $\mathrm{F} 1 \mathrm{sh}$ & Shortnose sturgeon & $\mathrm{FE}$ & & YR & Possible & $\mathrm{N}$ \\
\hline Fort Stewart & FORSCOM & Rept1le & Eastern indigo snake & ET & & YR & Possible & $\mathrm{N}$ \\
\hline Stewart & FORSCOM & B1rd & Arctic peregrine falcon & ET & & M & Possible & $\mathrm{R}$ \\
\hline Fort Stewart & FORSCOM & Reptile & Loggerhead sea turtle & FT & & Adfacent & Possible & $\mathrm{R}$ \\
\hline Fort stewart & FORSCOM & Bird : & Plping plover & FT & & W & Possible & $\mathrm{N}$ \\
\hline Fort Stewart & FORSCOM & Reptile & American alligator & FTSA & & YR & Current & \\
\hline Fort Stewart & FORSCOM & B1rd & Brown pelican & SE & & YR & Possible & $-\mathrm{N}$ \\
\hline Story & TRADOC & Mamma 1 & Pungo mouse & $\mathrm{C} 2$ & & YR & Possible & $\mathrm{N}=$ \\
\hline Fort story & TRADOC & Fish & Shortnose sturgeon & EE & & YR & Possible & $\mathrm{R}$ \\
\hline Fort Story & TRADOC & B1rd & Bachman's warbler & FE & & M & Ext1rpated & $\mathrm{HR}$ \\
\hline Fort Story & TRADOC & B1rd & American peregrine falcon & EE & & M & Possible & $\mathrm{R}$ \\
\hline Fort Story & TRADOC & Reptile & Kemp's ridley sea turtie & FE & & Adjacent & Possible & $\mathrm{R}$ \\
\hline Story & TRADOC & Rept1le & Atlant1c leatherback & $\mathrm{FE}$ & & Adjacent & Possible & $\mathrm{R}$ \\
\hline Fort story & TRADOC & Rept1le & Green turtle & FT & & Adfacent & Possible & $\mathrm{N}$ \\
\hline Fort Story & TRADOC & B1rd & Arctic peregrine falcon & ET & & $M$ & Possible & $\mathrm{R}$ \\
\hline Fort Story & TRADOC & B1rd & Piping plover & ET & & T & Possible & $\mathrm{R}$ \\
\hline Fort story & TRADOC & Rept1le & Loggerhead sea turtle & FT & & SR & Possible & $\mathrm{N}$ \\
\hline Fort Story & TRADOC & Bird & Yellow-crowned night heron & RSE & & YR & Possible & $\mathrm{R}$ \\
\hline Eort Story & TRADOC & B1rd & Northern harrier & RSE & & M & Possible & HR \\
\hline Fort story & TRADOC & B1rd & Gull-billed tern & RSE & & $\mathrm{T}$ & Possible & $\mathrm{R}$ \\
\hline Fort story & TRADOC & B1rd & Henslow's sparrow & RSE & & B & Possible & $\mathrm{N}$ \\
\hline Fort Story & TRADOC & Bird & Sedge wren & RSE & & W & Possible & $\mathrm{R}$ \\
\hline Fort story & TRADOC & B1rd & Eastern least tern & RSE & & B & Likely & $\mathrm{N}$ \\
\hline Fort Story & TRADOC & Rept1le & Eastern chlcken turtle & SE & & YR & Possible & $\mathrm{N}$ \\
\hline Fort story & TRADOC & Bird & w1lson's plover & SE & & T & Possible & $\mathrm{N}$ \\
\hline Indlana AAP & AMC & B1rd & M1grant loggerhead shrike & $\mathrm{C} 2$ & SE & B & Possible & $\mathrm{NH}$ \\
\hline Indiana AAP & AMC & Reptile & K1rtland's snake & C2 & ST & YR & Possible & $\mathrm{N}$ \\
\hline Indiana AAP & AMC & Fish & Blue sucker & $\mathrm{C} 2$ & & YR & Possible & $\mathrm{N}$ \\
\hline Indiana AAP & AMC & Amphiblan & Hellbender & C2 & SE & YR & Current & \\
\hline Indiana AAP & AMC & Moilusk & Rough rabbit's foot & $\mathrm{C} 2$ & & YR & Extirpated & $H R$ \\
\hline Indlana AAP & AMC & B1rd & Bald eagle & $\mathrm{FE}$ & & M & Possible. & $\mathrm{N}$ \\
\hline Indiana AAP & AMC & Mollusk & Plnk mucket pearly mussel & $\mathrm{FE}$ & & YR & Possible & HR \\
\hline Indiana AAP & AMC & Mollusk & Rough plgtoe & FE & & YR & Extirpated & HR \\
\hline Indiana AAP & AMC & B1rd & American peregrine falcon & $\mathrm{FE}$ & & M & Possible & $\mathrm{N}$ \\
\hline Indiana AAP & AMC & Mammal & Gray bat & $\mathrm{FE}$ & & PB & Possible & $\mathrm{N}$ \\
\hline Indiana AAP & AMC & Mollusk & Tuberculed-blossom pearly mussel & $1 \mathrm{FE}$ & & YR & Ext1rpated & HR \\
\hline Indiana AAP & AMC & Mollusk & Orange-footed pearly mussel & $\mathrm{FE}$ & & YR & Ext1rpated & HR \\
\hline Indlana AAP & AMC & Mamma 1 & Indlana bat & $\mathrm{FE}$ & & F, M & Possible & $\mathrm{N}$ \\
\hline Indlana AAP & AMC & B1rd & Interior least tern & $\mathrm{FE}$ & & T & Possible & $\mathrm{N}$ \\
\hline Indiana AAP & AMC & B1rd & Arctic peregrine falcon & FT & & M & Possible & $\mathrm{N}$ \\
\hline Indlana AAP & AMC & Bird & Osprey & SE & & M & Possible & $\mathrm{R}$ \\
\hline Indiana AAP & AMC & B1rd & American bittern & SE & & M & Possible & $\mathrm{R}$ \\
\hline Indiana AAP & AMC & Mollusk & Long-soldd & SE & & YR & Posslble & $\mathrm{HR}$ \\
\hline Indiana AAP & AMC & Bird & Black-crowned night heron & SE & & M & Possible & $\mathrm{NH}$ \\
\hline Indlana AAP & AMC & Mamma 1 & Evening bat & SE & & E, M & Possible & $\mathrm{N}$ \\
\hline Indiana AAP & AMC & B1rd & Great egret & SE & & M & Possible & $\mathrm{R}$ \\
\hline Indiana AAP & AMC & B1rd & Northern harrier & SE & & YR & Possible & $\mathrm{R}$ \\
\hline Indiana AAP & AMC & B1rd & Yellow-crowned night heron & SE & & B & Possible & $\mathrm{R}$ \\
\hline Indlana AAP & AMC & Mamma 1 & Bobcat & SE & & YR & Possible & $\mathrm{N}$ \\
\hline Indlana AAP & AMC & B1rd & Barn owl & SE & & YR & Possible & $\mathrm{R}$ \\
\hline Indlana AAP & AMC & Mamma 1 & Badger & ST & & YR & Possible & $\mathbf{R}$ \\
\hline Jefferson PG & AMC & Bird & Migrant loggerhead shrike & $\mathrm{C} 2$ & SE & B & Possible & R \\
\hline Jefferson PG & AMC & Rept1le & Kirtland's snake & $\mathrm{C} 2$ & ST & YR & Current & \\
\hline Jefferson PG & AMC & Fish & Eastern sand darter & $\mathrm{C} 2$ & & YR & Possible & $\mathrm{N}$ \\
\hline Jefferson PG & AMC & B1rd & American peregrine falcon & FE & & M & Possible & $\mathrm{R}$ \\
\hline Jefferson PG & AMC & B1rd & Bald eagle & FE & & W & Possible & $\mathrm{R}$ \\
\hline Jefferson PG & AMC & Mammal & Gray bat & FE & & PB & Possible & $\mathrm{N}$ \\
\hline Jefferson PG & AMC & Mamma 1 & Indiana bat & $\mathrm{FE}$ & & F, M & Possible & $\mathrm{N}$ \\
\hline Jefferson PG & AMC & B1rd & Arctic peregrine falcon & ET & & M & Possible & $\mathrm{R}$ \\
\hline Jefferson PG & AMC & Bird & Northern harrier & SE & & YR & Possible & $\mathrm{R}$ \\
\hline
\end{tabular}


Appendix A (continued)

\begin{tabular}{|c|c|c|c|c|c|c|c|c|}
\hline Installation & $\mathrm{ACOM}$ & Taxon & Species & Status & & sidency & Occurrance & \\
\hline Jefferson PG & AMC & Bird & Great egret & SE & & M & Possible & $\mathrm{R}$ \\
\hline Jefferson PG & AMC & Mamma 1 & Evening bat & SE & & B & Possible & $R$ \\
\hline Jefferson PG & AMC & Bird & Yellow-crowned night heron & SE & & B & Possible & $R$ \\
\hline Jefferson PG & AMC & B1 $=\mathrm{d}$ & King rail & SE & & B & Possible & R \\
\hline Jefferson PG & AMC & B1rd & Barn ow 1 & SE & & YR & Possible & $\mathrm{N}$ \\
\hline Jefferson PG & AMC & B1rd & Amerlcan blttern & SE & & M & Possible & R \\
\hline Jefferson PG & AMC & Mamma 1 & Bobcat & SE & & $\mathrm{YR}$ & Possible & $\mathrm{R}$ \\
\hline Jefferson PG & AMC & Blrd & Henslow's sparrow & ST & & B & Possible & $\mathrm{R}$ \\
\hline Jollet AAP & AMC & Bird & Swalnson's hawk & $3 \mathrm{C}$ & SE & M & Possible & R \\
\hline Jollet AAP & AMC & Reptile & KIrtland's snake & $\mathrm{C} 2$ & & YR & Possible & $\mathrm{N}$ \\
\hline Jollet AAP & AMC & Mollusk & Salamander mussel & C2 & & YR & Possible & \\
\hline Jollet AAP & AMC & Bird & Migrant loggerhead shrike & c2 & ST & B & Current & \\
\hline Jollet AAP & AMC & Mollusk & Spectaclecase & C2 & $S E$ & YR & Possible & $\mathrm{N}$ \\
\hline Jollet AAP & AMC & Mollusk & Cracklng pearly musse 1 & $\mathrm{FE}$ & & YR & Possible & N \\
\hline Jollet AAP & AMC & Bird & Least tern & $\mathrm{FE}$ & & PB & Possible & $\mathrm{R}$ \\
\hline Jollet AAP & AMC & Bird & Bald eagle & FE & & w & Current & \\
\hline Jollet AAP & AMC & Mamma 1 & Indlana bat & FE & & B, F & Possible & \\
\hline Jollet AAP & AMC & B1rd & American peregrine falcon & FE & & $M$ & Possible & \\
\hline Jollet AAP & AMC & B1rd & - Arctic peregrine falcon & FT & & M & Possible & $\mathbf{R}$ \\
\hline Jollet AAP & AMC & Bird & Sharp-shinned hawk & SE & & YR & Possible & R \\
\hline Jollet AAP & AMC & Bird & Great egret & SE & & B & Likely & \\
\hline Jollet AAP & AMC & Bird & Cooper's hawk & SE & & YR & Possible & N \\
\hline Jollet AAP & AMC & Bird & Black-crowned night heron & SE & & B & Likely & \\
\hline Jollet AAP & AMC & B1rd & Snowy egret & SE & & PB & Possible & $\mathrm{N}$ \\
\hline Jollet AAP & AMC & Bird & Little blue heron & SE & & PB & Possible & $\mathrm{N}$ \\
\hline Jollet AAP & AMC & B1rd & Pled-billed grebe & SE & & M & Possible & N \\
\hline Jollet AAP & AMC & Mollusk & Slippershell mussel & $S E$ & & YR & Possible & $\mathrm{N}$ \\
\hline Jollet AAP & AMC & Bird & Forster's tern & SE & & B & Former & \\
\hline Jollet AAP & AMC & Bird & Upland sandp1per & SE & & B & Current & \\
\hline Jollet AAP & AMC & B1rd & Sandh111 crane & SE & & M & Possible & $\mathrm{N}$ \\
\hline Jollet AAP & AMC & Blrd & Least bittern & SE & & B & Possible & $\mathrm{R}$ \\
\hline Jollet AAP & AMC & Mollusk & Higgins eye pearly mussel & SE & & YR & Possible & \\
\hline Joliet AAP & AMC & Mollusk & Ralnbow & SE & & YR & Possible & \\
\hline Jollet AAP & AMC & B1rd & Common tern & SE & & M & Possible & \\
\hline Jollet AAP & AMC & Reptile & Spotted turtle & SE & & YR & Possible & $\mathrm{N}$ \\
\hline Jollet AAP & AMC & Bird & Osprey & SE & & M & Possible & $\mathrm{N}$ \\
\hline Jollet AAP & AMC & Mollusk & Snuff box & SE & & YR & Possible & $\mathrm{N}$ \\
\hline Jollet AAP & AMC & B1rd & Short-eared ow 1 & SE & & YR & Possible & $\mathrm{N}$ \\
\hline Jollet AAP & AMC & Bird & Yellow-headed blackb1rd & SE & & B & Possible & \\
\hline Jollet AAP & AMC & B1rd & American b1ttern & SE & & B & L1kely & \\
\hline Jollet AAP & AMC & B1rd & Double-crested cormorant & SE & & M & Possible & N \\
\hline Jollet AAP & AMC & B1rd & Barn ow 1 & SE & & YR & Possible & \\
\hline Joliet AAP & AMC & Bird & Northern harrier & SE & & B & Current & \\
\hline Jollet AAP & AMC & B1rd & Red-shouldered hawk & SE & & B & Possible & \\
\hline Jollet AAP & AMC & B1rd & Black tern & SE & & B & Possible & \\
\hline Jollet AAP & AMC & Fish & River redhorse & ST & & YR & Possible & $\mathrm{N}$ \\
\hline Jollet AAP & AMC & Bird & Brown creeper & ST & & B & Possible & \\
\hline Jollet AAP & AMC & B1rd & Common moorhen & ST & & B & Possible & \\
\hline Jollet AAP & AMC & Fish & Blacknose shiner & ST & & YR & Possible & \\
\hline Jollet AAP & AMC & Mollusk & Sheepnose & ST & & YR & Possible & \\
\hline Jollet AAP & AMC & Fish & Blgeye shiner & ST & & YR & Possible & $N$ \\
\hline Jollet AAP & AMC & Mollusk & Elephant ear & ST & & YR & Possible & \\
\hline Jollet AAP & AMC & B1rd & Bewlck's wren & ST & & M & Possible & \\
\hline Jollet AAP & AMC & Bird & Henslow's sparrow & ST & & B & Likely & \\
\hline Jollet AAP & AMC & Mamma 1 & Bobcat & ST & & YR & Possible & \\
\hline Jollet AAP & AMC & Mamma 1 & River otter & ST & & YR & Possible & \\
\hline Jollet AAP & AMC & Mollusk & Creek heelsplitter & ST & & YR & Possible & \\
\hline Jollet AAP & AMC & B1rd & Veery & ST & & B & Likely & \\
\hline Letterkenny AD & AMC & B1rd & Appalachlan Bewlck's wren & C1 & ST & B & Posstble & \\
\hline Letterkenny $\mathrm{AD}$ & AMC & Reptile & Bog turtle & $\mathrm{C2}$ & SE & YR & Likely & \\
\hline Letterkenny $A D$ & AMC & Mamma 1 & Eastern small-footed bat & $\mathrm{C} 2$ & SE & M & Possible & \\
\hline Letterkenny AD & AMC & Mamma 1 & Indlana bat & $\mathrm{FE}$ & & M & Possible & \\
\hline Letterkenny $A D$ & AMC & Bird & Arctic peregrine falcon & FT & & M & Possible & \\
\hline Letterkenny AD & AMC & Rept1le & Red-beliled turtle & SE & & YR & Possible & $\mathrm{N}$ \\
\hline Letterkenny AD & AMC & B1rd. & Grasshopper sparrow & ST & & B & Current & \\
\hline Letterkenny $A D$ & AMC & Insect & Buckmoth & ST & & & Possible & $\mathrm{N}$ \\
\hline Letterkenny $\mathrm{AD}$ & AMC & Bird & Upland sandplper & ST & & B & Possible & \\
\hline Letterkenny $\mathrm{AD}$ & AMC & B1rd & Henslow's sparrow & ST & & B & Current & \\
\hline Lexington/Bluegrass & AMC & B1rd & Appalachlan Bewick's wren & $\mathrm{Cl}$ & & B & Possible & \\
\hline Lexington/Bluegrass & AMC & Amphibian & Hellbender & $\mathrm{C} 2$ & & YR & Possible & \\
\hline Lexington/Bluegrass & AMC & B1rd & Bachman's sparrow & $\mathrm{c} 2$ & ST & B & Possible & $\mathrm{R}$ \\
\hline Lexington/Bluegrass & AMC & Mamma 1 & Southern pygmy shrew & $\mathrm{C} 2$ & & YR & Possible & \\
\hline Lexington/Bluegrass & AMC & Fish & Eastern sand darter & $\mathrm{C} 2$ & & YR & Possible & \\
\hline Lexington/Bluegrass & AMC & Bird & Migrant loggerhead shrike & $\mathrm{C} 2$ & & YR & Possible & $\mathrm{R}$ \\
\hline Lexington/Bluegrass & AMC & Mamma 1 & Eastern woodrat & $\mathrm{C} 2$ & & YR & Possible & \\
\hline Lexington/Bluegrass & AMC & Mamma 1 & Eastern small-footed bat & $\mathrm{C2}$ & & $\mathrm{F}, \mathrm{M}$ & Possible & $\mathrm{R}$ \\
\hline Lexington/Bluegrass & AMC & Mamma 1 & Rafinesque's big-eared bat & $\mathrm{C} 2$ & ST & F, $M$ & Possible & \\
\hline Lex1ngton/Bluegrass & AMC & Mamma 1 & Red wolf & FE & & YR & Extirpated & \\
\hline Lexington/Bluegrass & AMC & B1rd & Bald eagle & $\mathrm{FE}$ & & W & Possible & $\mathbf{R}$ \\
\hline Lexington/Bluegrass & AMC & Bird & American peregrine falcon & $\mathrm{FE}$ & & $\mathrm{T}$ & Possible & R \\
\hline Lexington/Bluegrass & AMC & Mamma 1 & Gray bat & $\mathrm{FE}$ & & F & Possible & \\
\hline Lexington/Bluegrass & AMC & Mamma 1 & Indlana bat & FE. & & F, M & Possible & \\
\hline Lexington/Bluegrass & AMC & Mamma I & Eastern cougar & FE & & YR & Ext1rpated & \\
\hline Lexington/Bluegrass & AMC & Mamma 1 & Virginla big-eared bat & FE & & $\mathrm{F}, \mathrm{M}$ & Possible & \\
\hline Lexington/Bluegrass & AMC & Bird & Arctic peregrine falcon & FT & & T & Possible & \\
\hline Lexington/Bluegrass & AMC & Bird & Black-crowned night heron & SE & & B & Possible & \\
\hline
\end{tabular}


Appendix A (continued)

\begin{tabular}{|c|c|c|c|c|c|c|c|c|}
\hline Installation & MACOM & Taxon & Species & Status & & idency & Occurranc & \\
\hline Lexington/Bluegrass & AMC & B1rd & Anerican coot & SE & & W & Possible & R \\
\hline Lexington/Bluegrass & AMC & Bird & Upland sandplper & $S E$ & & M & Possible & $\mathrm{R}$ \\
\hline Lexington/Bluegrass & AMC & B1rd & Pled-billed grebe & SE & & YR & Possible & $\ddot{R}$ \\
\hline Lexington/Bluegrass & AMC & B1rd & Lark sparrow & SE & & B & Possible & $\mathrm{N}$ \\
\hline Lexington/Bluegrass & AMC & Bird & Amertcan bittern & SE & & T & Possible & NH \\
\hline Lexington/Bluegrass & AMC & B1rd & Osprey & SE & & M & Possible & R \\
\hline Lexington/Bluegrass & AMC & Mamma 1 & Evening bat & SE & & B & Possible & $\mathbf{R}$ \\
\hline Lexington/Bluegrass & AMC & B1rd & Yollow-crowned nlght heron & ST & & B & Possible & $\mathrm{R}$ \\
\hline Milan AAP & AMC & Bird & Appalachian Bewick's wren & $\mathrm{Cl}$ & ST & YR & Possible & $\ddot{N}$ \\
\hline Milan AAP & AMC & Rept 1le & Copperbelly water snake & $\mathrm{C} 2$ & & YR & Possible & R \\
\hline Milan AAP & AMC & Reptile & Aligator snapping turtle & $\mathrm{C2}$ & & YR & Possible & $\ddot{R}$ \\
\hline Milan AAP & AMC & Mammal & Rafinesque's big-eared bat & c2 & & $\mathrm{YR}$ & Possible & $\mathrm{N}$ \\
\hline M11an AAP & AMC & B1rd & Bachman's sparrow & $\mathrm{C} 2$ & SE & B & Possible & $\mathbf{R}$ \\
\hline Milan AAP & AMC & B1rd & American peregrine falcon & $\mathrm{FE}$ & & w & Possible & $\mathrm{R}$ \\
\hline Milan AAP & AMC & B1rd & Bald eagle & $F E$ & & W & Possible & R \\
\hline Milan AAP & AMC & Bird & Ivory-billed woodpecker & $\mathrm{FE}$ & & YR & Possible & $\mathrm{HR}$ \\
\hline Milan AAP & AMC & B1rd & Interfor least tern & FE & & T & Possible & R \\
\hline M1lan AAP & AMC & Mamma 1 & Eastern cougar & FE & & YR & Unlikely & HR \\
\hline Milan AAP & AMC & Mamma 1 & Red wolf & FE & & YR & Extirpated & HR \\
\hline Milan AAP & AMC & B1rd & Bachman's warbler & FE & & M & Extirpated & HR \\
\hline Milan AAP & AMC & Mammal & Gray bat & $\mathrm{FE}$ & & E, M & Possible & $\mathrm{R}$ \\
\hline Milan AAP & AMC & Mamma 1 & Indiana bat & FE & & F, M. & Possible & $\mathrm{R}$ \\
\hline Milan AAP & AMC & B1rd & Red-cockaded woodpecker & FE & & YR & Ext1rpated & HR \\
\hline Milan AAP & AMC & B1rd & Arctic peregrine falcon & FT & & $\mathrm{M}$ & Possible & $\mathrm{R}$ \\
\hline Milan AAP & - AMC & Bird & Virginla rail & SE & & $\mathrm{T}$ & Possible & $\mathrm{N}$ \\
\hline M1lan AAP & AMC & B1rd & Klng rail & SE & & B & Possible & $\mathrm{N}$ \\
\hline Milan AAP & AMC & Bird & Least bittern & ST & & $\mathrm{T}$ & Possible & R \\
\hline Milan AAP & AMC & B1rd & Black-crowned night heron & ST & & YR & Possible & $\mathrm{N}$ \\
\hline Milan AAP & AMC & B1rd & Northern harrier & ST & & $\mathrm{T}$ & Possible & $\mathrm{N}$ \\
\hline Milan AAP & AMC & Mamma 1 & River otter & ST & & YR & Unlikely & $\mathrm{N}$ \\
\hline M1lan AAP & AMC & B1rd . & Yellow-crowned night heron & ST & & B & Possible & $\mathrm{N}$ \\
\hline Milan AAP & AMC & B1rd & Cooper's. hawk & ST & & YR & Possible & $\mathrm{N}$ \\
\hline Milan AAP & AMC & B1rd & Sharp-sh1nned hawk & ST & & YR & Possible & $\mathrm{N}$ \\
\hline Milan AAP & AMC & B1rd & Grasshopper sparrow & ST & & B & Possible & $\mathrm{N}$ \\
\hline Milan AAP & AMC & B 1 rd & Great blue heron & ST & & YR & Possible & R \\
\hline Mississ1pp1 AAP & AMC & Mamma 1 & Louslana black bear & $\mathrm{Cl}$ & & YR & Possible & R \\
\hline Mississ1pp1 AAP & AMC & Reptile & Black pine snake & $\mathrm{C2}$ & SE & YR & Possible & $\mathrm{N}$ \\
\hline M1ss1ss1pp1 AAP & AMC & Fish & Gulf sturgeon & $\mathrm{C} 2$ & & YR & Likely & $\mathrm{R}$ \\
\hline Mississipp1 AAP & AMC & Amphlbian & Dusky gopher frog & $\mathrm{C} 2$ & & YR & Possible & $\mathrm{R}$ \\
\hline Mississ1pp1 AAP & AMC & Fish & Frecklebell1ed madtom & $\mathrm{C} 2$ & SE & YR & Possible & $\mathrm{N}$ \\
\hline M1ssissipp1 AAP & AMC & B1rd & Bachman's warbler & $\mathrm{FE}$ & & $\mathrm{T}$ & Extirpated & HR \\
\hline Mississ1pp1 AAP & AMC & B1rd & American peregrine falcon & $\mathrm{FE}$ & & M & Possible & $\mathrm{R}$ \\
\hline Mississ1pp1 AAP & AMC & Mamma 1 & Red wolf & $\mathrm{EE}$ & & YR & Ext1rpated & HR \\
\hline M1ssissipp1 AAP & AMC & B1rd & Bald eagle & $\mathrm{FE}$ & & $B, F$ & Possible & $\mathrm{N}$ \\
\hline Mississipp1 AAP & AMC & Mamma 1 & Florida panther & FE & & YR & Possible & HR \\
\hline Mississtpp 1 AAP & AMC & B1rd & Red-cockaded woodpecker. & $\mathrm{FE}$ & & YR & Possible & R \\
\hline Mississipp1 AAP & AMC & B1rd & Ivory-b1lled woodpecker & FE & & YR & Ext1rpated & HR \\
\hline Mississipp1 AAP & AMC & Bird & Arctic peregrine falcon & FT & & M & Possible & $\mathrm{R}$ \\
\hline Mississipp 1 AAP & AMC & Rept1le & Eastern Indigo snake & FT & & YR & Possible & $\mathrm{R}$ \\
\hline Mississipp1 AAP & AMC & Reptile & Ringed sawback turtle & FT & & YR & Possible & $\mathrm{R}$ \\
\hline Mississippi AAP & AMC & Reptile & Gppher tortolse & FT & & YR & Posstble & $\mathrm{R}$ \\
\hline MIssisslpp1 AAP & AMC & Reptile & Anerican alligator & FTSA & & YR & Possible & $\mathrm{R}$ \\
\hline Mississippl AAP & AMC & Reptile & Ralnbow snake & SE & & YR & Possible & $\mathbf{R}$ \\
\hline Mississtpp1 AAP & AMC & B1rd & Brown pellcan & SE & & $\mathrm{T}$ & Possible & $\mathbf{R}$ \\
\hline Mississippi AAP & AMC & Fish & AE lantic sturgeon & SE & & YR & Likely & R \\
\hline Newport AAP & AMC & Mollusk & Northern riffleshell & C2 & SE & YR & Possible & $\mathrm{N}$ \\
\hline Newport AAP & AMC & Rept1le & Klrtland's snake & C2 & ST & YR & Possible & $\mathrm{R}$ \\
\hline Newport AAP & AMC & Blrd & MIgrant loggerhead shrike & $\mathrm{c} 2$ & SE & B & Possible & $\mathrm{N}$ \\
\hline Newport AAP & AMC & Mollusk & CLubshel1 & $\mathrm{C} 2$ & SE & YR & Possible & $\mathrm{N}$ \\
\hline Newport AAP & AMC & Fish & Eastern sand darter & $\mathrm{C2}$ & & YR & Possible & $\mathrm{N}$ \\
\hline Newport AAP & AMC & Insect & Karner blue butterfly & $\mathrm{C2}$ & SE' & YR & Possible & $\mathrm{N}$ \\
\hline Newport AAP & AMC & Fish & Blue sucker & $\mathrm{c} 2$ & & YR & Possible & $\mathrm{N}$ \\
\hline Newport AAP & AMC & Mollusk & White wartyback & $\mathrm{FE}$ & & $\mathrm{YR}$ & Possible & $\mathrm{N}$ \\
\hline Newport AAP & AMC & Mamma 1 & Indlana bat & $\mathrm{FE}$ & & M & Possible & $\mathrm{N}$ \\
\hline Newport AAP & AMC & Mollusk & Rough plgtoe & $\mathrm{FE}$ & & YR & Possible & NH \\
\hline Newport AAP & AMC & Mollusk & Fat pocketbook & FE & & YR & Possible & $\mathrm{N}$ \\
\hline Newport AAP & AMC & B1rd & Bald eagle & $\mathrm{FE}$ & & $\mathrm{M}$ & Possible & $\mathrm{N}$ \\
\hline Newport AAP & AMC & Mollusk & White catspaw & $\mathrm{PE}$ & & YR & Possible & $\mathrm{N}$ \\
\hline Newport AAP & AMC & Mollusk & Fanshell & $\mathrm{PE}$ & & YR & Possible & $\mathrm{N}$ \\
\hline Newport AAP & AMC & Blrd & Northern harrier & SE & & YR & Possible & R \\
\hline Newport AAP & AMC & B1rd & Barn ow 1 & SE & & YR & Possible & $\mathrm{R}$ \\
\hline Newport AAP & AMC & Mollusk & Shuff box & SE & & YR & Possible & $\mathrm{N}$ \\
\hline Newport AAP & AMC & B1rd & American bittern & SE & & $M$ & Possible & $\mathrm{R}$ \\
\hline Newport AAP & AMC & B1rd & Black-crowned nlght heron & SE & & M & Possible & $\mathbf{R}$ \\
\hline Newport AAP & AMC & Mollusk & Sheepnose & SE & & YR & Possible & $\mathrm{N}$ \\
\hline Newport AAP & AMC & B1rd & osprey & SE & & M & Possible & R \\
\hline Newport AAP & AMC & Mamma 1 & Eyening bat & SE & & B & Possible & $\mathrm{N}$ \\
\hline Newport AAP & AMC & Mollusk & Long-solid & SE & & YR & Possible & $\mathrm{N}$ \\
\hline Newport AAP & AMC & B1rd & Yellow-crowned night heron & SE & & B & Possible & $\mathrm{N}$ \\
\hline Newport AAP & AMC & B1rd & Great egret & SE & & $\mathrm{PB}$ & Possible & R \\
\hline Newport AAP & AMC & B1rd & Sedge wren & ST & & B & Possible & R \\
\hline Plcatinny Arsenal & AMC & Mamma 1 & New England cottonta1l & $\mathrm{C} 2$ & & YR & Possible & $\mathrm{R}$ \\
\hline Picatinny Arsenal & AMC & Mamma 1 & Eastern woodrat & C2 & ST & YR & Current & \\
\hline Plcatinny Arsenal & AMC & Rept1le & Bog turtle & $\mathrm{C2}$ & SE & YR & Current & \\
\hline Plcatinny Arsenal & AMC & Insect & Hebard's noctuld moth & $\mathrm{C} 2$ & & & Possible & $\mathrm{N}$ \\
\hline Picatinny Arsenal & AMC & Insect & Mltchell's satyr butterfly & $\mathrm{C} 2$ & & & Extirpated & $\mathrm{NH}$ \\
\hline
\end{tabular}


Appendix A (continued)

\begin{tabular}{|c|c|c|c|c|c|c|c|c|c|}
\hline \multicolumn{2}{|c|}{ Installation } & MACOM & Taxon & Species & Status & & esidency & Occurranc & \\
\hline Picatinny & Arsenal & AMC & Mamma 1 & Mountain lion & FE & & $Y R$ & Extirpated & HR \\
\hline Picatinny & Arsenal & AMC & B1rd & Bald eagle & FE & & $\mathrm{T}$ & Possible & R \\
\hline Plcatinny & Arsenal & AMC & B1rd & American peregrine falcon & FE & & M & Possible & $\mathrm{R}$ \\
\hline Plcatinny & Arsenal & AMC & Bird & Arctic peregrine falcon & ET & & M & Possible & $\mathrm{R}$ \\
\hline Plcatinny & Arsenal & AMC & Bird & Vesper sparrow & SE & & $\ddot{M}$ & Current & \\
\hline P1catinny & Arsenal & AMC & Amphiblan & Trembley's salamander & SE & & YR & Possible & $\mathrm{N}$ \\
\hline Picatinny & Arsenal & AMC & Bird & Cliff swallow & SE & & M & Current & \\
\hline P1catinny & Arsenal & AMC & Amph1b1an & Blue-spotted salamander & SE & & YR & Possible & $\mathrm{N}$ \\
\hline Picatinny & Arsenal & AMC & B1rd & Northern harrier & SE & & M & Current & \\
\hline P1catinny & Arsenal & AMC & Bird & Cooper's hawk & SE & & $\mathrm{T}$ & Current & \\
\hline Plcatinny & Arsenal & AMC & B1rd & Pled-billed grebe & SE & & $M$ & Current & \\
\hline P1catinny & Arsenal & AMC & B1rd & Sedge wren & SE & & B & Possible & $\mathrm{N}$ \\
\hline Plcatinny & Arsenal & AMC & Bird & Upland sandp1per & SE & & B & Current & \\
\hline P1catinny & Arsenal & AMC & Rept11e & Timber rattlesnake & SE & & YR & Current & \\
\hline Plcatinny & Arsenal & AMC & Blrd & Short-eared owl & SE & & W & Possible & $\mathrm{R}$ \\
\hline P1catinny & Arsenal & AMC & Bird & American bittern & $\mathrm{SE}$ & & M & Current & \\
\hline P1catinny & Arsenal & AMC & Rept1le & Wood turtle & ST & & YR & Current & \\
\hline Plcatinny & Arsenal & AMC & Amphibian & Longtall salamander & ST & & YR & Possible & $\mathrm{N}$ \\
\hline Plcatinny & Arsenal & AMC & Bird & Red-shouldered hawk & ST & & $\mathrm{T}$ & Current & \\
\hline Picatinny & Arsenal & AMC & Bird & Osprey & ST & & M & Possible & $\mathrm{R}$ \\
\hline P1catinny & Arsenal & AMC & B1rd & Red-headed woodpecker & ST & & YR & Possible & $\mathrm{R}$ \\
\hline P1catinny & Arsenal & AMC & Bird & Northern goshawk & ST & & YR & Current & \\
\hline Picatinny & Arsenal & AMC & Bird & Bobollnk & ST & & B & Possible & $\mathrm{N}$ \\
\hline Plcatinny & Arsenal & AMC & B1rd & Great blue heron & ST & & YR & Current & \\
\hline Plcatinny & Arsenal & AMC & Bird & Yellow-crowned night heron & ST & & B & Possible & $\mathrm{N}$ \\
\hline Plcatinny & Arsenal & AMC & B1rd & Barred ow 1 & ST & & YR & Current & \\
\hline Plcatinny & Arsenal & AMC & Bird & Black rall & ST & & $\mathrm{T}$ & Possible & $\mathrm{N}$ \\
\hline Picatinny & Arsenal & AMC & B1rd & Savannah sparrow & ST & & $M$ & Current & \\
\hline Plcatinny & Arsenal & AMC & Fish & Brook trout & ST & & YR & Current & \\
\hline Picatinny & Arsenal & AMC & B1rd & Grasshopper sparrow & ST & & B & Possible & $\mathrm{N}$ \\
\hline Radford AA & $\mathrm{AP}$ & AMC & B1rd & Appalachian Bewick's wren & C1 & & $\mathrm{T}$ & Possible & NH \\
\hline Radford AAI & & AMC & Amphiblan & Mudpuppy & $\mathrm{C} 2$ & & YR & Possible & $\mathrm{N}$ \\
\hline Radford $A A$ & $A P$ & AMC & Fish & Elnescale saddled darter & $\mathrm{C} 2$ & & $Y R$ & Possible & $\mathrm{N}$ \\
\hline Radford AA: & AP & AMC & Fish & Kanawha minnow & $\mathrm{C} 2$ & & YR & Possible & $\ddot{N}$ \\
\hline Radford AAI & AP & AMC & Amphibian & Hellbender & $\mathrm{C} 2$ & & YR & Possible & $\mathrm{N}$ \\
\hline Radford AAI & $A P$ & AMC & B1rd & Migrant loggerhead shrike & $\mathrm{C} 2$ & SE & YR & Possible & $\mathrm{N}$ \\
\hline Radford AAI & $A P$ & AMC & Mollusk & Virgina fringed mountain snall & $\mathrm{FE}$ & & YR & Possible & $\mathrm{N}$ \\
\hline Radford AAI & AP & AMC & B1rd & American peregrine falcon & FE & & $\mathrm{T}$ & Possible & $\mathrm{R}$ \\
\hline Radford AAI & AP & AMC & B1rd & Bachman's warbler & $\mathrm{FE}$ & & M & Ext1rpated & HR \\
\hline Radford AAP & & AMC & Mamma 1 & Eastern cougar & FE & & YR & Extirpated & HR \\
\hline Radford AAF & $\mathrm{AP}$ & AMC & Mamma 1 & Indlana bat & FE & & $\mathrm{T}$ & Possible & $\mathrm{R}$ \\
\hline Radford AAE & AP & AMC & B1rd & Northern harrier & RSE & & $\mathrm{T}$ & Possible & $\mathrm{R}$ \\
\hline Radford AAE & & AMC & Blrd & Yellow-crowned night heron & RSE & & B & Possible & NH \\
\hline Ravenna AAF & & AMC & Rept11e & Eastern massasauga & $\mathrm{C} 2$ & & YR & Possible & $\mathrm{NH}$ \\
\hline Ravenna AAE & & AMC & Blrd & American peregrine falcon & FE & & M & Possible & $\mathrm{R}$ \\
\hline Ravenna $\mathrm{AAE}$ & & AMC & Mamma 1 & Indlana bat & $\mathrm{FE}$ & & $\mathrm{F}$ & Possible & R \\
\hline Ravenna AAE & $A P$ & AMC & B1rd & Arctic peregrine falcon & FT & & M & Possible & $\mathrm{R}$ \\
\hline Ravenna AAE & & AMC & Mollusk & Eastern pondmussel & SE & & YR & Possible & $\mathrm{N}$ \\
\hline Ravenna AAE & AP & AMC & B1rd & Northern harrier & SE & & B & Possible & $\mathrm{N}$ \\
\hline Ravenna AAF & & AMC & B1rd & American bittern & SE & & B & Possible & $\mathrm{N}$ \\
\hline Ravenna AAE & & AMC & Fish & Mounta1n brook lamprey & SE & & YR & Possible & $\mathrm{N}$ \\
\hline Ravenna AAE & AP & AMC & B1rd & Bew1ck's wren & SE & & B & Possible & $\mathrm{NH}$ \\
\hline Ravenna AAE & & AMC & B1rd & Barn ow 1 & SE & & B & Possible & R \\
\hline Ravenna AAF & AP & AMC & B1rd & K1ng ra11 & SE & & B & Possible & $\mathrm{NH}$ \\
\hline Ravenna AAE & & AMC & B1rd & Northern waterthrush & SE & & B & Possible & $\mathrm{N}$ \\
\hline Redstone $\mathrm{Ar}$ & Arsenal & AMC & B1rd & Appalachian Bew1ck's wren & $\mathrm{Cl}$ & ST & $M$ & Possible & R \\
\hline Redstone $\mathrm{Ar}$ & Arsenal & AMC & Mollusk & Oyster mussel & $\mathrm{C} 2$ & & YR & Unl1kely & $\mathrm{NH}$ \\
\hline Redstone $\mathrm{Ar}$ & Arsenal & AMC & Mollusk & slabside pearly mussel & $\mathrm{C} 2$ & & YR & Possible & $\mathrm{N}$ \\
\hline Redstone AI & Arsenal & AMC & Mollusk & Tennessee clubshell & $\mathrm{C} 2$ & & YR & Unlikely & $\mathrm{NH}$ \\
\hline Redstone AI & Arsenal & AMC & Fish & Tuscombla darter & $\mathrm{C} 2$ & & YR & Possible & $\mathrm{N}$ \\
\hline Redstone Ar & Arsenal & AMC & Mollusk & Fanshell & $\mathrm{C} 2$ & & YR & Possible & $\mathrm{NH}$ \\
\hline Redstone Ar & Arsenal & AMC & Mollusk & Tan riffleshell & $\mathrm{FE}$ & & YR & Possible & $\mathrm{NH}$ \\
\hline Redstone Ar & Arsenal & AMC & Mamma 1 & Indiana bat & $\mathrm{FE}$ & & F & Possible & $\mathrm{N}$ \\
\hline Redstone A & Arsenal & AMC & Mollusk & Orange-footed pearly mussel & FE & & YR & Possible & $\mathrm{N}$ \\
\hline Redstone $A$ & arsenal & AMC & B1rd & Wood stork & $\mathrm{FE}$ & & M & Possible & $\mathrm{N}$ \\
\hline Redstone $\mathrm{A}$ : & irsenal & AMC & Mollusk & Plnk mucket pearly mussel & $\mathrm{FE}$ & & YR & Possible & $\mathrm{N}$ \\
\hline Redstone $A$ & Irsenal & AMC & Mamma 1 & Florida panther & FE & & YR & Ext1rpated & HR \\
\hline Redstone A: & Irsenal & AMC & B1rd & Bald eagle & FE & & W & Current & \\
\hline Redstone A & Arsenal & AMC & Bird & Bachman's warbler & $\mathrm{FE}$ & & $\mathrm{T}$ & Ext1rpated & $\mathrm{HR}^{*}$ \\
\hline Redstone A & Irsenal & AMC & Mamma 1 & Gray bat & $\mathrm{FE}$ & & $\mathrm{F}$ & Possible & $\mathrm{N}$ \\
\hline Redstone A. & Arsenal & AMC & Mollusk & Shiny pigtoe & FE & & YR & Possible & $\mathrm{N}$ \\
\hline Redstone A & Arsenal & AMC & Mollusk & Pale lilliput pearly mussel & FE & & YR & Possible & $\mathrm{N}$ \\
\hline Redstone A & Arsenal & AMC & Mollusk & Fine-rayed pigtoe & $\mathrm{FE}$ & & $Y R$ & Possible & $\mathrm{NH}$ \\
\hline Redstone $A$ : & Arsenal & AMC & Fish & slackwater darter & $\mathrm{FE}$ & & YR & Possible & $\mathrm{N}$ \\
\hline Redstone $\mathrm{A}$ : & Arsenal & AMC & Crustacean & Alabama cave shrimp & FE & & YR & Current & \\
\hline Redstone A & Arsenal & AMC & Mollusk & Dromedary pearly mussel & $\mathrm{FE}$ & & $\mathrm{YR}$ & Unlikely & $\mathrm{NH}$ \\
\hline Redstone A & Arsenal & AMC & Bird & American peregrine falcon & $\mathrm{FE}$ & & $\mathrm{T}$ & Possible & $\mathrm{R}$ \\
\hline Redstone $A$. & Arsenal & AMC & Mammal & Red wolf & EE & & YR & Ext1rpated & $\mathrm{HR}$ \\
\hline Redstone A & Arsenal & AMC & Mollusk & Rough pigtoe & FE & & YR & Possible & $\mathrm{N}$ \\
\hline Redstone $\mathrm{A}$ & Arsenal & AMC & Mollusk & B1rdwing pearly mussel & $\mathrm{FE}$ & & YR & Possible & $\mathrm{NH}$ \\
\hline Redstone $\mathrm{A}$ & Arsenal & AMC & Bird & Arctic peregrine falcon & FT & & $\mathrm{T}$ & Possible & $\mathrm{R}$ \\
\hline Redstone A & Arsenal & AMC & Bird & Plping plover & ET & & $\mathrm{M}$ & Possible & $\mathrm{R}$ \\
\hline Redstone A & Arsenal & AMC & Rept1le & American alligator & FTSA & & YR & Possible & $\mathrm{N}$ \\
\hline Redstone A & Arsenal & AMC & Mollusk & Ring pink & PE & & YR & Possible & R \\
\hline Savanna $A D$ & & AMC & B1rd & Swainson's hawk & $3 \mathrm{C}$ & SE & M & Possible & $\mathrm{R}$ \\
\hline Savanna $A D$ & & AMC & Rept1le & Easțern massasauga & $\mathrm{C} 2$ & & YR & Possible & $\mathrm{N}$ \\
\hline
\end{tabular}




\begin{tabular}{|c|c|c|c|c|c|c|c|c|c|c|}
\hline Install & lation & MA & $\mathrm{COM}$ & Taxon & Species & Status & & sidency & Occurran & \\
\hline Savanna & a $\mathrm{AD}$ & & AMC & Fish & Lake sturgeon & C2 & ST & YR & Possible & N \\
\hline Savanna & $\begin{array}{ll}\text { a } & A D \\
\text { a } & A D\end{array}$ & & AMC & B1rd & Mlgrant loggerhead shrike & $\mathrm{C} 2$ & ST & YR & Possible & R \\
\hline Savanna & a $A D$ & & AMC & Mollusk & Scaleshell & $\mathrm{C} 2$ & & YR & Possible & $\mathrm{NH}$ \\
\hline Savanna & a $A D$ & & AMC & Mollusk & Spectaclecase & $\mathrm{C} 2$ & SE & YR & Possible & $\mathrm{NH}$ \\
\hline Savanna & a $\mathrm{AD}$ & & AMC & B1rd & Bald eagle & FE & & YR & Current & \\
\hline Savanna & a $A D$ & & AMC & B1rd & American peregrine falcon & $\mathrm{FE}$ & & M & Unilkely & R \\
\hline Savanna & a $A D$ & & AMC & Mollusk & H1ggins eye pearly mussel & FE & & YR & Possible & $\mathrm{N}$ \\
\hline Savanna & a $A D$ & & AMC & Mamma 1 & Indiana bat & FE & & B, F & Possible & $\mathrm{N}$ \\
\hline Savanna & a $\mathrm{AD}$ & & AMC & B1rd & Arctic peregrine falcon & FT & & M & Unllkely & $\mathrm{R}$ \\
\hline Savanna & a $\mathrm{AD}$ & & AMC & B1rd & Yellow-headed blackblrd & SE & & B & Possible & $\mathrm{N}$ \\
\hline Savanna & a $A D$ & & AMC & Mollusk & Rainbow & $\mathrm{SE}$ & & YR & Possible & $\mathrm{N}$ \\
\hline Savanna & a $\mathrm{AD}$ & & AMC & Bird & Upland sandpiper & SE & & B & Current & \\
\hline Savanna & a $A D$ & & AMC & B1rd & Barn ow 1 & SE & & YR & Possible & $\mathrm{N}$ \\
\hline Savanna & a $\mathrm{AD}$ & & AMC & B1rd & Great egret & SE & & B & Current & \\
\hline Savanna & a $A D$ & & AMC & B1rd & Double-crested cormorant & SE & & M & Possible & $\mathrm{N}$ \\
\hline Savanna & a $A D$ & & AMC & B1rd & Long-eared ow 1 & SE & & M & Possible & $\mathrm{R}$ \\
\hline Savanna & a $A D$ & & AMC & Bird & Amerlcan bittern & SE & & B & Possible & $\mathrm{R}$ \\
\hline Savanna & a $\mathrm{AD}$ & & AMC & B1rd & Sharp-sh1nned hawk & SE & & YR & Possible & $\mathrm{N}$ \\
\hline Savanna & $\mathrm{a} \cdot \mathrm{AD}$ & & AMC & Bird & Red-shouldered hawk & $S E$ & & B & Current & \\
\hline Savanna & a $A D$ & & AMC & Mollusk & Snuff box & SE & & YR & Possible & $\mathrm{N}$ \\
\hline Savanna & a $A D$ & & AMC & B1rd & Black-crowned nlght heron & SE & & F & Possible & $\mathrm{R}$ \\
\hline Savanna & a $\mathrm{AD}$ & & AMC & B1rd & Osprey & SE & & M & Possible & $\mathrm{N}$ \\
\hline Savanna & a $A D$ & & AMC & Fish & Pallid shiner & SE & & YR & Possible & $\mathrm{N}$ \\
\hline Savanna & a $\mathrm{AD}$ & & AMC & B1rd & Little blue heron & SE & & M & Possible & $\mathrm{R}$ \\
\hline Savanna & a $A D$ & & AMC & Mamma 1 & White-talled Jackrabb1t & SE & & YR & Current & \\
\hline Savanna & a $A D$. & & AMC & Bird & Least b1ttern & SE & & B & Possible & $\mathrm{R}$ \\
\hline Savanna & a $\mathrm{AD}$ & & AMC & B1rd & Cooper's hawk & SE & & YR & Current & \\
\hline Savanna & a $A D$ & & AMC & B1rd & Northern harrier & SE & & YR & Possible & $\mathrm{R}$ \\
\hline Savanna & a $\mathrm{AD}$ & & AMC & B1rd & Black tern & SE & & M & Possible & $\mathrm{N}$ \\
\hline Savanna & a $A D$ & & AMC & B1rd & Short-eared owl & SE & & YR & Possible & $\mathrm{N}$ \\
\hline Savanna & $\mathrm{AD}$ & & AMC & Mammal & River otter & ST & & YR & Current & \\
\hline Savanna & $\mathrm{AD}$ & & AMC & Mollusk & Sheepnose & ST & & YR & Possible & $\mathrm{NH}$ \\
\hline Savanna & $\mathrm{AD}$ & & AMC & Mollusk & Elephant ear & ST & & YR & Possible & NH \\
\hline Savanna & $A \mathrm{AD}$ & & AMC & Mamma 1 & Bobcat & ST & & YR & Possible & $\mathrm{R}$ \\
\hline Savanna & a $A D$ & & AMC & Bird & Brown creeper & ST & & YR & Current & \\
\hline Savanna & a $A D$ & & AMC & Rept1le & Dusty hognose snake & ST & & YR & Likely & $\mathrm{N}$ \\
\hline Savanna & a $A D$ & & AMC & B1rd & Veery & ST & & M & Possible & $\mathrm{R}$ \\
\hline Seneca. & $\mathrm{AD}$ & & AMC & Reptile & Bog turtle & $\mathrm{C} 2$ & SE & YR & Possible & $\mathrm{R}$ \\
\hline Seneca & $A D$ & & AMC & B1rd & Bald eagle & FE & & $M$ & Posslble & $\mathrm{N}$ \\
\hline Seneca & $A D$ & & AMC & Marnma 1 & Indiana bat & FE & & T & Possible & $\mathrm{R}$ \\
\hline Seneca & $\mathrm{AD}$ & & AMC & B1rd & American peregrine falcon & $\mathrm{FE}$ & & M & Possible & $\mathrm{R}$ \\
\hline Seneca & $A D$ & & AMC & Mamma 1 & Mounta1n ilon & FE & & YR & Ext1rpated & HR \\
\hline Seneca & $\mathrm{AD}$ & & AMC & B1rd & Arctic peregrine falcon & FT & & M & Possible & $\mathrm{R}$ \\
\hline Seneca & $A D$ & & AMC & Rept11e & Massasauga & SE & & YR & Possible & $\mathrm{R}$ \\
\hline Seneca & $\mathrm{AD}$ & & AMC & Bird & Golden eagle & SE & & M & Possible & $\mathrm{R}$ \\
\hline Seneca & $A D$ & & AMC & B1rd & Red-shouldered hawk & ST & & M & Possible & $\mathrm{R}$ \\
\hline Seneca & $\mathrm{AD}$ & & AMC & B1rd & Common tern & ST & & $M$ & Possible & $\mathrm{N}$ \\
\hline Seneca & $\mathrm{AD}$ & & AMC & Rept1le & Timber rattlesnake & ST & & YR & Possible & $\mathrm{R}$ \\
\hline Seneca & $A D$ & & AMC & B1rd & Osprey & ST & & M & Possible & $\mathrm{R}$ \\
\hline Seneca & $\mathrm{AD}$ & & AMC & Bird & Northern harrier & ST & & M & Possible & $\mathrm{R}$ \\
\hline Sunny $\mathrm{P}$ & Point $M$ & IT & MTMC & Mamma 1 & Rafinesque's big-eared bat & $\mathrm{C} 2$ & & YR & Possible & $\mathrm{R}$ \\
\hline Sunny $\mathrm{P}$ & Point $\mathrm{M}$ & IT & MTMC & Mollusk & Rare skipper & $\mathrm{C} 2$ & & & Current & \\
\hline Sunny $P$ & Point $\mathrm{M}$ & & MTMC & B1rd & Bachman's sparrow & $\mathrm{C} 2$ & & YR & Possible & $\mathrm{N}$ \\
\hline Sunny $\mathrm{P}$ & Point $M$ & IT & MTMC & Amphibian & Carolina gopher frog & C2 & & YR & Current & \\
\hline Sunny $\mathrm{B}$ & Point $M$ & & MTMC & Mollusk & Magnificant ramshorn & C2 & SE & YR & Current & \\
\hline Sunny $\mathrm{B}$ & Point $M$ & IT & MTMC & B1rd & Bald eagle & FE & & B & Possible & $\mathrm{R}$ \\
\hline Sunny $\mathrm{E}$ & Point $\mathrm{M}$ & IT & MTMC & B1rd & Red-cockaded woodpecker & FE & & YR & Current & \\
\hline Sunny & Point $M$ & IT & MTMC & B1rd & K1rtland's warbler & $\mathrm{FE}$ & & M & Possible & $\mathrm{N}$ \\
\hline Sunny & Point $M$ & & MTMC & B1rd & American peregrine falcon & $\mathrm{FE}$ & & $\mathrm{W}$ & Possible & $\mathrm{R}$ \\
\hline Sunny & Point $\mathrm{M}$ & IT & MTMC & Rept1le & Hawksbill turtle & $\mathrm{FE}$ & & Adjacent & Possible & $\mathrm{R}$ \\
\hline Sunny $\mathrm{F}$ & Point $M$ & IT & MTMC & Rept1le & Kemp's ridley sea turtle & FE & & Adjacent & Possible & $\mathrm{R}$ \\
\hline Sunny & Point $M$ & IT & MTMC & Mamma 1 & Eastern cougar & $\mathrm{FE}$ & & YR & Ext1rpated & HR \\
\hline Sunny, & Polnt $M$ & IT & MTMC & B1rd & Bachman's warbler & $\mathrm{FE}$ & & T & Ext1rpated & $\mathrm{R}$ \\
\hline Sunny & Point $M$ & IT & MTMC & Fish & Shortnose sturgeon & FE & & YR & Possible & $\mathrm{N}$ \\
\hline Sunny & Point $M$ & IT & MTMC & Mamma 1 & West Indian manatee & $\mathrm{FE}$ & & Adfacent & Possible & $\mathrm{R}$ \\
\hline Sunny & Point M & IT & MTMC & Rept1le & Green turtle & $\mathrm{FE}$ & & Adjacent & Possible & $\mathrm{R}$ \\
\hline Sunny & Point $M$ & IT & MTMC & Rept1le & Leatherback turtle & FE & & Adjacent & Possible & $\mathrm{R}$ \\
\hline Sunny : & Point $M$ & IT & MTMC & Bird & Roseate tern & FE & & M & Possible & $\mathrm{R}$ \\
\hline Sunny & Point $M$ & IT & MTMC & Bird & Ivory-b1lled woodpecker & FE & & YR & Ext1rpated & $\mathrm{HR}^{\circ}$ \\
\hline Sunny & Polnt M & IT & MTMC & Bird & Wood stork & $\mathrm{FE}$ & & PB & Possible & $\mathrm{R}$ \\
\hline Sunny & Point $M$ & IT & MTMC & Mamma 1 & Red wolf & EE & & YR & Extirpated & $\mathrm{HR}$ \\
\hline Sunny & Point $\mathrm{M}$ & IT & MTMC & Rept1le & Loggerhead sea turtle & ET & & Adjacent & Possible & $\mathrm{N}$ \\
\hline Sunny & Point $M$ & IT & MTMC & Bird & P1pling plover & ET & & W & Possible & $\mathrm{N}$ \\
\hline Sunny & Point $M$ & IT & MTMC & B1rd & Arctic peregrine falcon & FT & & W & Possible & $\mathbf{R}$ \\
\hline Sunny & Point $M$ & IT & MTMC & Rept1le & American alligator & FTSA & & YR & Possible & $\mathrm{N}$ \\
\hline U.S. M1 & 111tary & Academy & USMA & Mamma 1 & Eastern woodrat & $\mathrm{C} 2$ & SE & YR & Current & \\
\hline U.S. M. & 111 tary & Academy & USMA & Rept1le & Bog turtle & $\mathrm{C} 2$ & & YR & Current & \\
\hline U.S. M & 111 tary & Academy & USMA & Mammal & Eastern small-footed bat & $\mathrm{C} 2$ & & B & Possible & $\mathrm{R}$ \\
\hline U.S. M. & 111tary & Academy & USMA & B1rd & Mlgrant loggerhead shrike & $\mathrm{C} 2$ & & M & Possible & $\mathrm{R}$ \\
\hline U.S. M. & ilitary & Academy & USMA & B1rd & Bald eagle & FE & & W & Possible & $\mathrm{N}$ \\
\hline U.S. M & 111tary & Academy & USMA & Mammal & Mounta1n lion & FE & & YR & Ext1rpated & $\mathrm{HR}$ \\
\hline U.S. M. & ilitary & Academy & USMA & F1sh & Shortnose sturgeon & FE & & Adjacent & Possible & $\mathrm{R}$ \\
\hline U.S. M. & ilitary & Academy & USMA & Mamma 1 & Indlana bat & $\mathrm{FE}$ & & $\mathrm{T}$ & Possible & $\mathrm{N}$ \\
\hline U.S. M & 111tary & Academy & USMA & Bird & American peregrine falcon & $\mathrm{FE}$ & & M & Possible & R \\
\hline U.S. M. & $111 \operatorname{tary}$ & Academy & USMA & B1rd & Arctic peregrine falcon & $\mathrm{FT}$ & & M & Possible & $\mathrm{R}$ \\
\hline U.S. M & ilitary & Academy & USMA & BIrd & Golden eagle & SE & & M & Current & \\
\hline
\end{tabular}




\section{Appendix A (continued)}

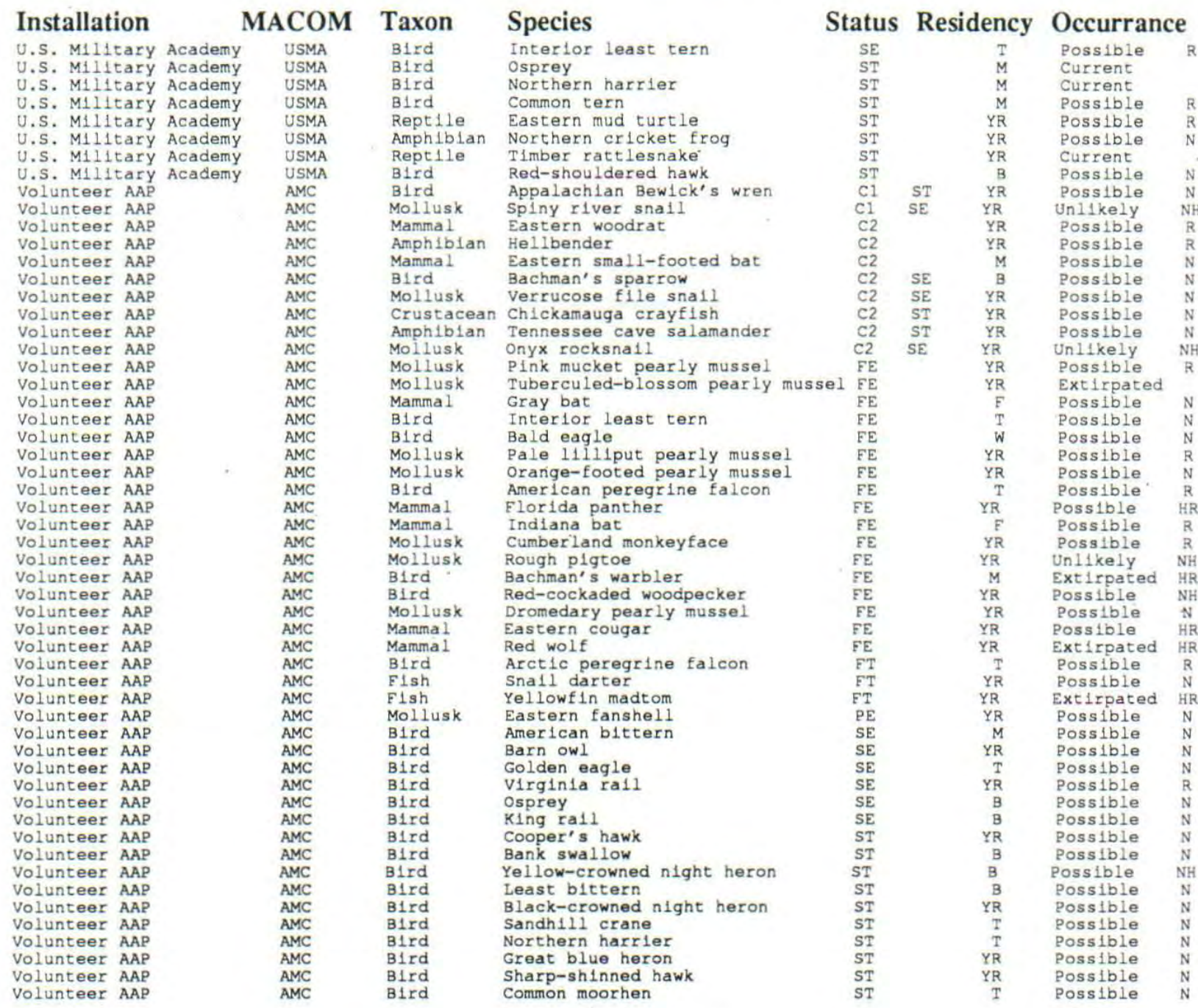

status

3A ; 3C ; C1 - Category 1; C2 - Category 2; FE - Federally endangered FT - Federally threatened; FTSA - FT due to similarity of appearance; PE - Proposed endangered; SE - State endangered; ST - State threatened.

Residency

Adfacent - adfacent areas (may be affected); B - Breeding season; F - Foraging; M - Migration; PB - Post breeding; T - Transient; W - Winter season; YR - Year round.

Occurrance

Current - Known to occur on the installation presently or within very recent past; Ext1rpated - Specles presentiy extirpated in the region but otherwise might have occurred; Likely - Likely to occur; Possible - May occur; Unlikely - Possible but unlikely to occur.

HR- Historic range; species historic range 1ncludes the installation; $\mathrm{N}$ - Nearby; species known to occur In the vicinity or within surrounding counties; NH - Nearby, Historic; historlcally known to occur as above; R - Range; species current range includes the installation. 
APPENDIX B: ENDANGERED SPECIES LISTING SORTED BY SPECIES AND STATUS

\begin{tabular}{|c|c|c|c|c|c|c|c|c|c|}
\hline Installation & МACOM & Taxon & Species & & Status & & esidency & Occurrance & \\
\hline Bager AAP & AMC & B1rd & Acadian flycatcher & & ST & & $M$ & Possible & $\mathrm{R}$ \\
\hline Fort McCoy & FORSCOM & Bird & Acadian flycatcher & & ST & & M & Possible & $\mathrm{N}$ \\
\hline Redstone Arsenal & AMC & Crustacean & Alabama cave shrimp & & $\mathrm{FE}$ & & YR & Current & \\
\hline Anniston $A D$ & AMC & Mollusk & Alabama live-bearing & g sna11 & $\mathrm{C} 2$ & & YR & Possible & NH \\
\hline Fort Mcclellan & TRADOC & Mollusk & Alabama 11ve-bearing & g sna11 & $\mathrm{C} 2$ & & YR & Possible & $\mathrm{NH}$ \\
\hline Fort Benning & TRADOC & Mollusk & Albany snail & & $\mathrm{C2}$ & & YR & Possible & $\mathrm{N}$ \\
\hline Milan AAP & AMC & Reptile & Alligator snapping $t$ & turtle & C2 & & YR & Possible & $\mathrm{R}$ \\
\hline Fort Campbel1 & FORSCOM & Rept11e & Alligator snapping $t$ & turtle & $\mathrm{C} 2$ & ST & YR & Possible & $\mathrm{N}$ \\
\hline Mississlpp1 AAP & AMC & Reptile & American alligator & & FTSA & & YR & Possible & $\mathrm{R}$ \\
\hline Fort Jackson & TRADOC & Reptile & American alligator & & ETSA & & YR & Possible & $\mathrm{R}$ \\
\hline Fort Gordon & TRADOC & Rept1le & American alligator & & FTSA & & $\mathrm{YR}$ & Possible & $\mathrm{R}$ \\
\hline Fort Benning & TRADOC & Rept1le & American alligator & & FTSA & & YR & Current & \\
\hline Camp Blanding & NGB & Reptile & American alligator & & ETSA & & YR & Likely & $\mathrm{R}$ \\
\hline Sunny Point MT & MTMC & Rept1le & American alligator & & ETSA & & YR & Possible & $\mathrm{N}$ \\
\hline Camp Shelby & NGB & Rept1le & American alligator & & ETSA & & YR & Possible & $\mathrm{N}$ \\
\hline Redstone Arsenal & AMC & Rept1le & American alligator & & ETSA & & YR & Possible & $\mathrm{N}$ \\
\hline Fort Bragg & FORSCOM & Rept 11 e & American alligator & & ETSA & & YR & Current & \\
\hline Fort Stewart & FORSCOM & Reptile & American alligator & & FTSA & & YR & Current & \\
\hline Newport AAP & AMC & Bird, & American bittern & & $S E$ & & M & Possible & $\mathrm{R}$ \\
\hline Ravenna AAP & AMC & B1rd & American bittern & & $S E$ & & B & Possible & $\mathrm{N}$ \\
\hline Fort Campbel1 & FORSCOM & Bird & American bittern & & SE & & YR & Possible & $\mathrm{R}$ \\
\hline Volunteer AAP & AMC & Bird & Amerlcan bittern & & SE & & M & Possible & $\mathrm{N}$ \\
\hline Lexington/Bluegrass & AMC & B1rd & American blttern & & SE & & $\mathrm{T}$ & Possible & $\mathrm{NH}$ \\
\hline Savanna $\mathrm{AD}$ & AMC & B1rd & Amerlcan bittern & & SE & & B & Possible & $\mathrm{R}$ \\
\hline Picatinny Arsenal & AMC & Bird & American bittern & & SE & & $M$ & Current & \\
\hline Camp Atterbury & NGB & B1rd & American bittern & & SE & & B & Possible & $\mathrm{R}$ \\
\hline Indiana AAP & AMC & Bird & Amerlcan bittern & & SE & & M & Possible & $\mathrm{R}$ \\
\hline Jefferson PG & AMC & B1rd & American bittern & & SE & & $M$ & Possible & $\mathrm{R}$ \\
\hline Fort knox & TRADOC & Bird & Amerlcan bittern & & SE & & T & Possible & $\mathrm{N}$ \\
\hline Jollet AAP & AMC & Bird & American bittern & & SE & & B & Likely & $\mathrm{N}$ \\
\hline Fort D1x & TRADOC & B1rd & American bittern & & ST & & B & Possible & $\mathrm{R}$ \\
\hline Camp Edwards & NGB & Fish & Amerlcan brook lampr & rey & ST & & Adjacent & Possible & R \\
\hline Lexington/Bluegrass & AMC & B1rd & American coot & & SE & & W & Possible & $\mathrm{R}$ \\
\hline Fort Knox & TRADOC & B1rd & American coot & & $S E$ & & $\mathrm{~T}$ & Possible & $\mathrm{N}$ \\
\hline Fort Campbell & FORSCOM & B1rd & American coot & & $\mathrm{SE}$ & & w & Possible & $\mathrm{N}$ \\
\hline Plcatinny Arsenal & AMC & B1rd & American peregrine $f$ & falcon & $\mathrm{FE}$ & & M & Possible & $\mathrm{R}$ \\
\hline Fort McCoy & FORSCOM & B1rd & American peregrine & falcon & $\mathrm{FE}$ & & $M$ & Current & \\
\hline Sunny Polnt MT & MTMC & Bird & American peregrine & falcon & FE & & W & Possible & $\mathrm{R}$ \\
\hline Fort Benning & TRADOC & B1rd & American peregrine & falcon & $\mathrm{FE}$ & & M & Possible & $\mathrm{R}$ \\
\hline Fort Campbell & FORSCOM & B1rd & American peregrine & falcon & $\mathrm{FE}$ & & $\mathrm{T}$ & Possible & $\mathrm{R}$ \\
\hline U.S. M111tary Academy & Y USMA & Bird & American peregrine & falcon & $\mathrm{FE}$ & & M & Possible & R \\
\hline Radford AAP & AMC & Bird & American peregrine & falcon & $F E$ & & $\mathrm{~T}$ & Possible & $\mathrm{R}$ \\
\hline Savanna $\mathrm{AD}$ & AMC & B1rd & American peregrine & falcon & FE & & M & Unlikely & $\mathrm{R}$ \\
\hline Bager AAP & AMC & B1rd & American peregrine & falcon & FE & & B & Possible & $\mathrm{N}$ \\
\hline Fort Devens & FORSCOM & B1rd & American peregrine & falcon & FE & & M & Possible & $\mathrm{R}$ \\
\hline Anniston $A D$ & AMC & B1rd & American peregrine & falcon & $\mathrm{FE}$ & & T & Unlikely & $\mathrm{R}$ \\
\hline Camp Grayling & NGB & B1rd & American peregrine & falcon & $\mathrm{FE}$ & & T & Possible & $\mathrm{R}$ \\
\hline Fort George Meade & FORSCOM & Bird & American peregrine & falcon & FE & & M & Possible & $\mathrm{R}$ \\
\hline Redstone Arsenal & AMC & B1rd & American peregrine & falcon & FE & & $\mathrm{T}$ & Possible & R \\
\hline Volunteer AAP & AMC & Bird & American peregrine & falcon & $\mathrm{FE}$ & & $\mathrm{T}$ & Possible & $\mathrm{R}$ \\
\hline Seneca $A D$ & AMC & Bird & American peregrine & falcon & $\mathrm{FE}$ & & M & Possible & $\mathrm{R}$ \\
\hline Camp Santiago & NGB & Bird & American peregrine & falcon & $\mathrm{FE}$ & & W & Possible & $\mathrm{N}$ \\
\hline Fort Pickett & FORSCOM & Bird & American peregrine & falcon & $\mathrm{FE}$ & & M & Possible & $\mathrm{R}$ \\
\hline Aberdeen PG & AMC & B1rd & American peregrine & falcon & FE & & $M$ & Possible & R \\
\hline Fort Drum & FORSCOM & B1rd & American peregrine & falcon & $\mathrm{FE}$ & & $M^{*}$ & Possible & $\mathrm{R}$ \\
\hline M1ssiss1pp1 AAP & AMC & Bird & American peregrine & falcon & $\mathrm{FE}$ & & M & Possible & R \\
\hline Jollet AAP & AMC & Bird & American peregrine & falcon & FE & & M & Possible & R \\
\hline Fort Lee & TRADOC & B1rd & American peregrine & falcon & FE & & $\mathrm{T}$ & Possible & R \\
\hline Fort Gordon & TRADOC & B1rd & Amertcan peregrine & falcon & $\mathrm{FE}$ & & M & Possible & $\mathrm{R}$ \\
\hline Fort stewart & FORSCOM & B1rd & American peregrine & falcon & FE & & M & Possible & $\mathbf{R}$ \\
\hline Jefferson PG & AMC & Bird & American peregrine & falcon & $\mathrm{FE}$ & & M & Possible & $\mathrm{R}$ \\
\hline Camp Atterbury & $\mathrm{NGB}$ & B1rd & American peregrine & falcon & $\mathrm{EE}$ & & M & Current & \\
\hline Fort D1x & TRADOC & B1rd & American peregrine & falcon & FE & & YR & Possible & $\mathrm{N}$ \\
\hline Fort Bragg & FORSCOM & Bird & American peregrine & falcon & $\mathrm{FE}$ & & W & Possible & $\mathrm{R}$ \\
\hline Fort story & TRADOC & B1rd & American peregrine & falcon & $\mathrm{FE}$ & & $M$ & Possible & $\mathrm{R}$ \\
\hline Fort Belvolr & MDW & B1rd & American peregrine $\mathrm{f}$ & falcon & $\mathrm{FE}$ & & M & Possible & $\mathrm{R}$ \\
\hline Fort Rucker & TRADOC & B1rd & American peregrine $f$ & falcon & $\mathrm{EE}$ & & $\mathrm{T}$ & Possible & R \\
\hline Fort Jackson & TRADOC & B1rd & American peregrine $f$ & falcon & $\mathrm{FE}$ & & $M$ & Possible & $\mathrm{R}$ \\
\hline Camp Blanding & NGB & B1rd & American peregrine f & falcon & $\mathrm{EE}$ & & w & Possible & $\ddot{R}$ \\
\hline Camp Edwards & NGB & B1rd & American peregrine & falcon & FE & & $\mathrm{B}^{*}$ & Possible & $\mathrm{R}$ \\
\hline Fort Mcclellan & TRADOC & B1rd & American peregrine & falcon & $\mathrm{FE}$ & & M & Unllkely & $\mathrm{R}$ \\
\hline Camp Shelby & NGB & B1rd & American peregrine & falcon & FE & & M & Possible & $\mathrm{R}$ \\
\hline Milan AAP & AMC & B1rd & American peregrine $\mathrm{f}$ & falcon & $\mathrm{EE}$ & & W & Possible & $\mathrm{R}$ \\
\hline Fort Eustis & TRADOC & Bird & American peregrine $\mathrm{f}$ & falcon & $\mathrm{EE}$ & & B & Possible & $\mathrm{N}$ \\
\hline Ravenna AAP & AMC & B1rd & American peregrine $\mathrm{f}$ & falcon & $\mathrm{EE}$ & & $M$ & Possible & $\mathrm{R}$ \\
\hline Fort Knox & TRADOC & B1rd & American peregrine $f$ & falcon & $\mathrm{EE}$ & & $\mathrm{T}$ & Possible & $\mathrm{R}$ \\
\hline Indiana AAP & $\mathrm{AMC}$ & BIrd & American peregrine $f$ & falcon & EE & & M & Possible & $\mathrm{N}$ \\
\hline Lexington/Bluegrass & AMC & Bird & American peregrine $f$ & falcon: & $\mathrm{FE}$ & & $\mathrm{T}$ & Possible & $\mathrm{R}$ \\
\hline Fort Campbell & FORSCOM & Bird & Appalachlan Bew1ck's & s wren & $\mathrm{C} 1$ & ST & YR & Possible & $\mathrm{N}$ \\
\hline Radford AAP & AMC & B1rd & Appalachian Bew1ck's & s wren & $\mathrm{Cl}$ & & T & Possible & $\mathrm{NH}$ \\
\hline Fort Gordon & TRADOC & B1rd & Appalachlan Bew1ck's & s wren & $\mathrm{C} 1$ & & $\mathrm{~B}$ & Possible & $\mathrm{R}$ \\
\hline Lexington/Bluegrass & AMC & Bird & Appalachian Bewick's & s wren & $\mathrm{Cl}$ & & B & Possible & $\mathrm{R}$ \\
\hline Fort Rucker & TRADOC & Blrd & Appalach1an Bew1ck's & $s$ wren & $\mathrm{Cl}$ & ST & $M$ & Unllkely & $\mathrm{R}$ \\
\hline Letterkenny $\mathrm{AD}$ & AMC & Bird & Appalachian Bew1ck's & s wren & $\mathrm{Cl}$ & ST & B & Possible & R \\
\hline M1lan AAP & AMC & Bird & Appalachlan Bewlck's & s wren & C1 & ST & YR & Possible & $\mathrm{N}$ \\
\hline Fort Jackson & TRADOC & Bird & Appalachlan Bewick's & s wren & $\mathrm{Cl}$ & & $\mathrm{B}$ & Possible & $\mathrm{R}$ \\
\hline
\end{tabular}


Appendix B (continued)

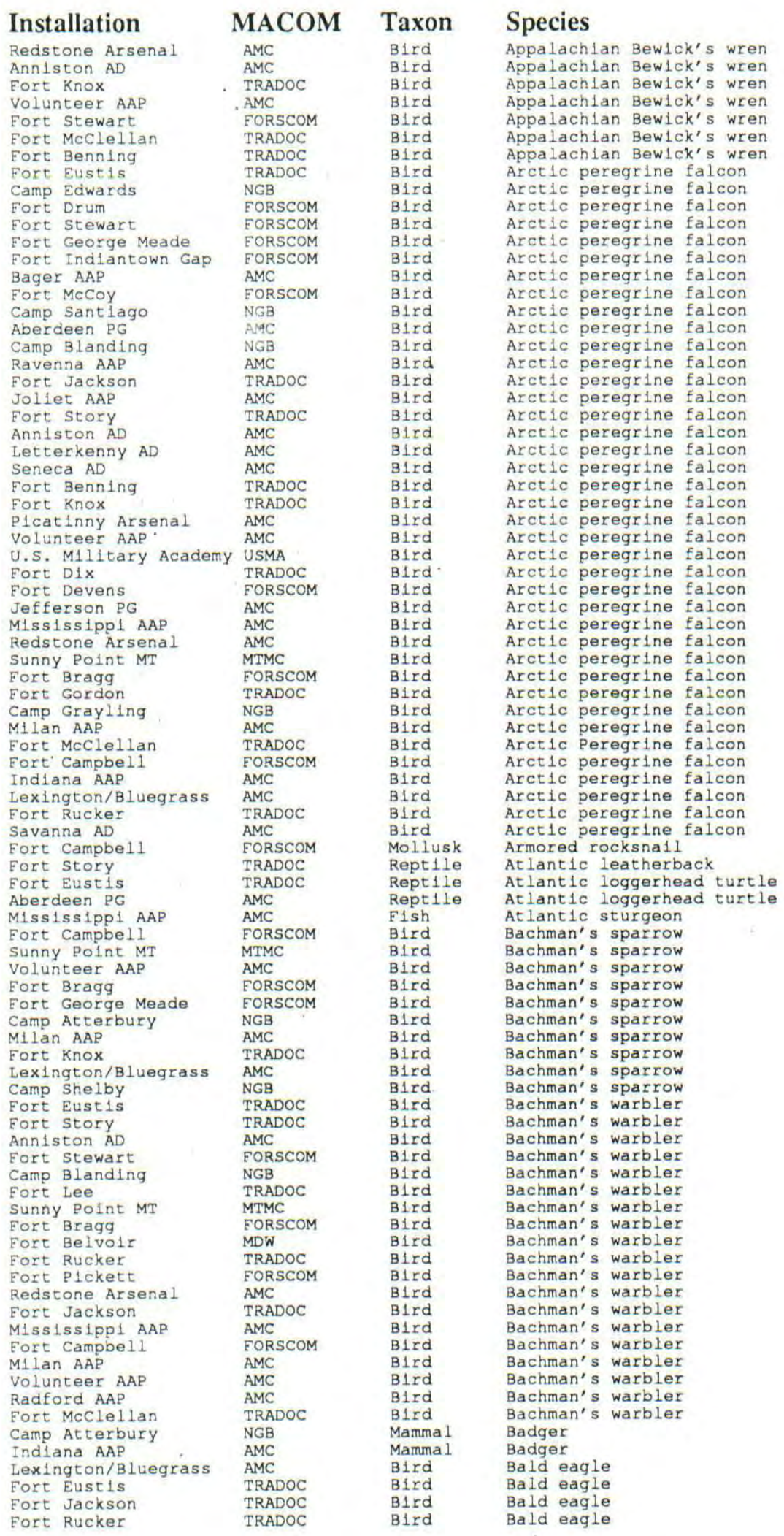

Status Residency Occurrance

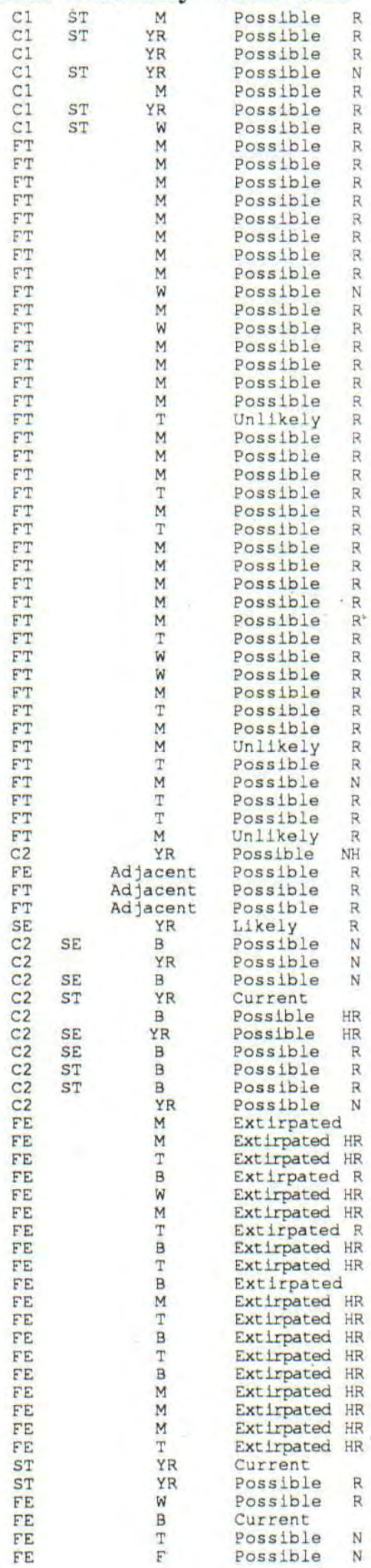


Appendix B (continued)

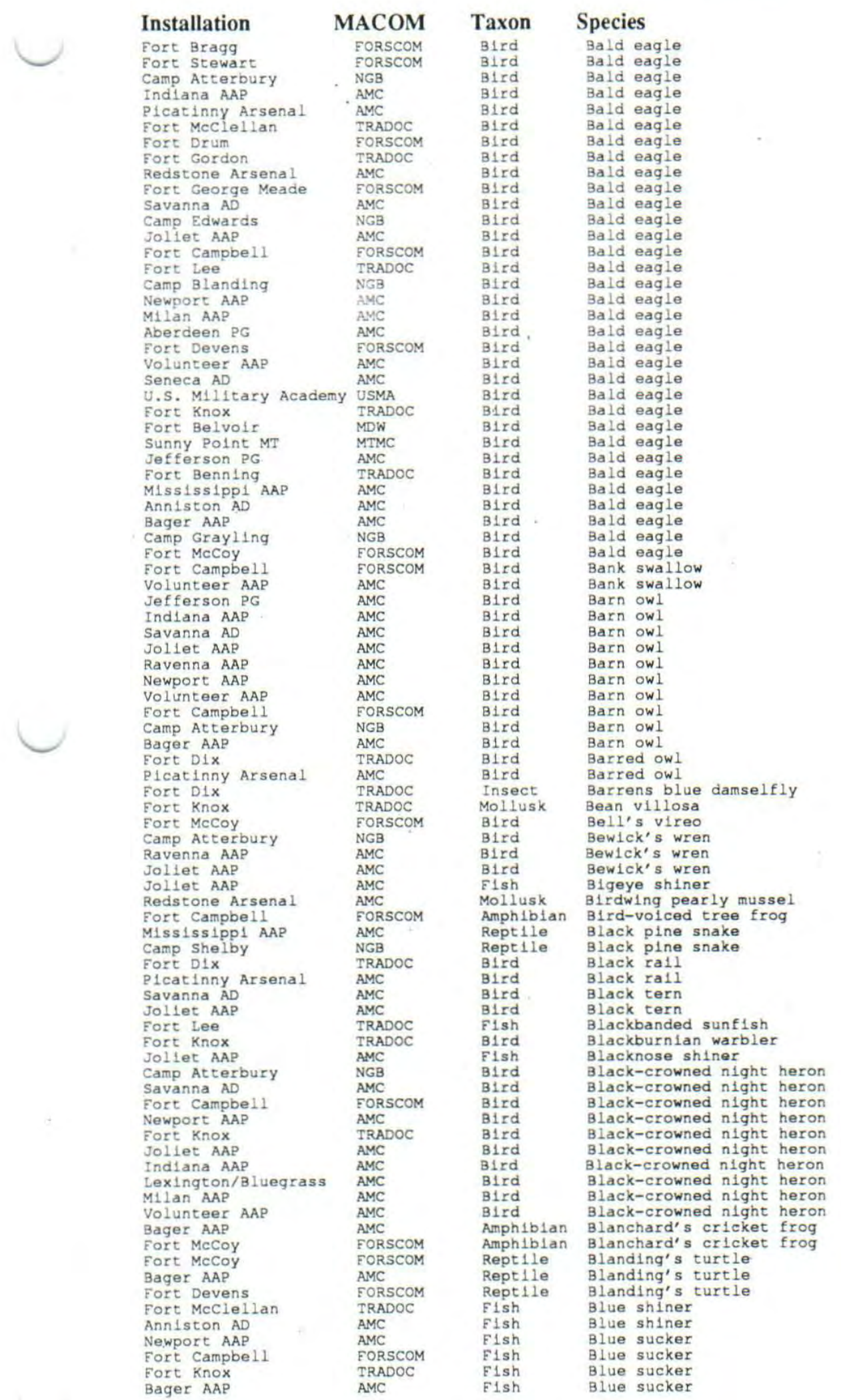

Status Residency Occurrance

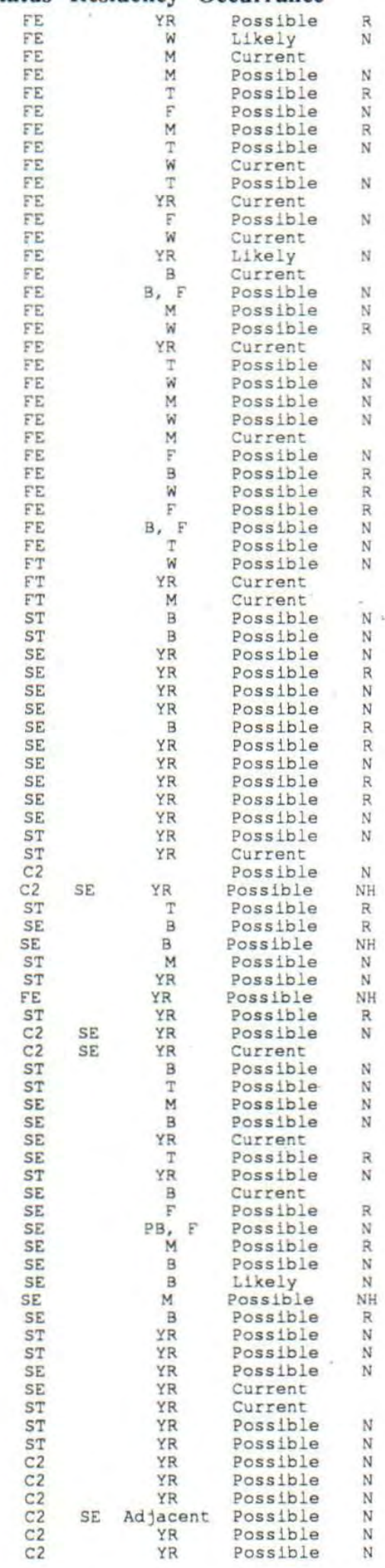


Appendix B (continued)

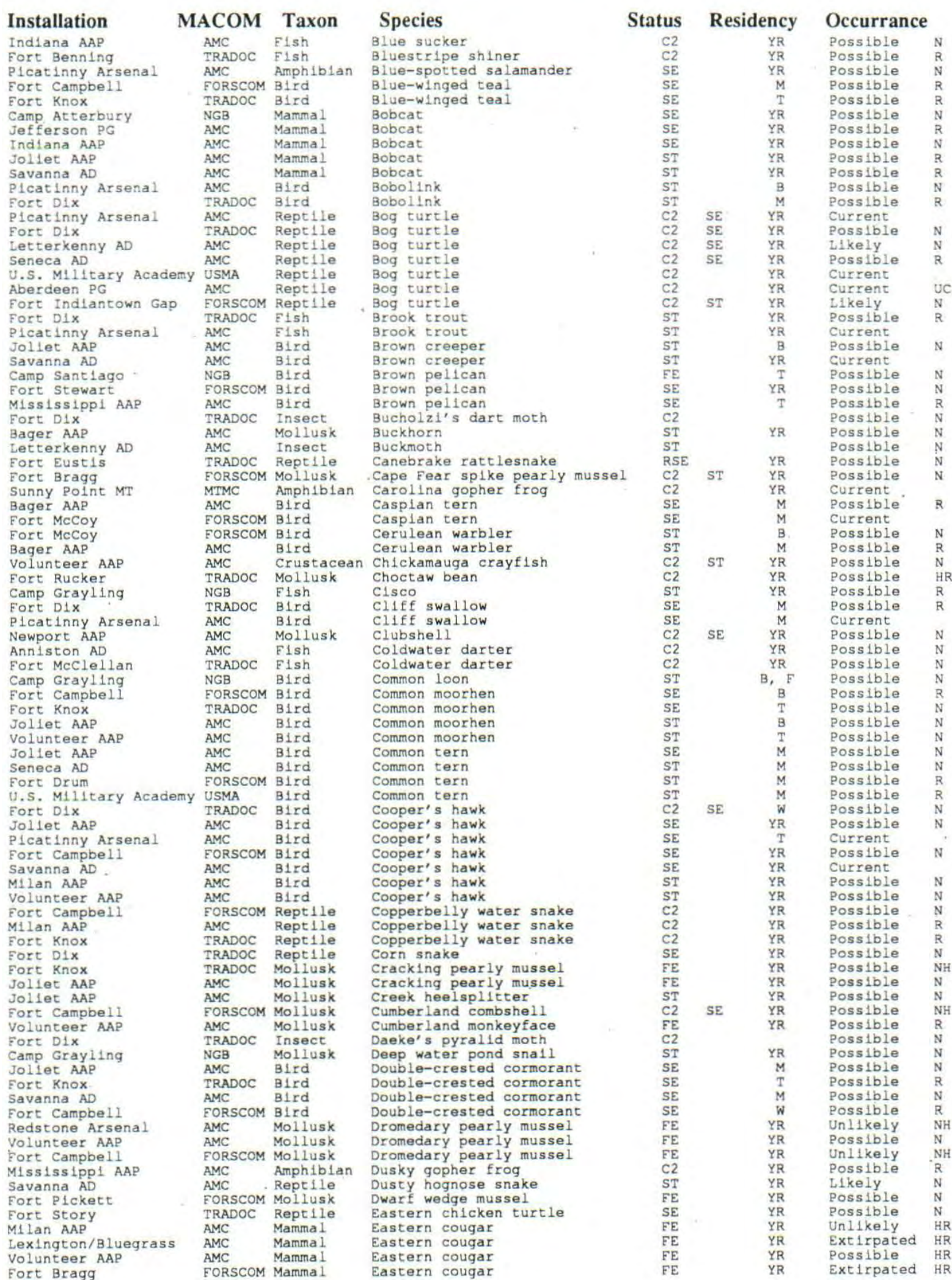




\begin{tabular}{|c|c|c|c|c|c|c|c|c|c|}
\hline Installation & АACOM & Taxon & Species & & Status & & esidency & Occurrance & \\
\hline Sunny Point MT & MTMC & Mammal & Eastern & cougar & $\mathrm{FE}$ & & YR & Ext1rpated & $\mathrm{HR}$ \\
\hline Fort knox & TRADOC & Mamma 1 & Eastern & cougar & $\mathrm{FE}$ & & YR & Ext1rpated & $\mathrm{HR}$ \\
\hline Fort Jackson & TRADOC & Mamma 1 & Eastern & cougar & $\mathrm{FE}$ & & YR & Extirpated & HR \\
\hline Fort Gordon & TRADOC & Mamma 1 & Eastern & cougar & $\mathrm{FE}$ & & $\mathrm{T}$ & Unl1kely & $\mathrm{HR}$ \\
\hline Fort Campbell & FORSCOM & Mamma 1 & Eastern & cougar & $E E$ & & YR & Possible & $\mathrm{HR}$ \\
\hline Radford AAP & AMC & Mamma 1 & Eastern & cougar & $\mathrm{FE}$ & & YR & Extirpated & $\mathrm{HR}$ \\
\hline Fort Devens & FORSCOM & Mammal & Eastern & cougar & $F E$ & & YR & Extirpated & $\mathrm{HR}$ \\
\hline Fort Stewart & FORSCOM & Mamma 1 & Eastern 0 & cougar & FE & & T & Possible & HR \\
\hline Fort Benning & TRADOC & Mamma 1 & Eastern $c$ & cougar & $\mathrm{FE}$ & & T & Unlikely & $\mathrm{HR}$ \\
\hline Fort Campbel1 & FORSCOM & Mollusk & Eastern & fanshell & $P E$ & & YR & Possible & $\mathrm{NH}$ \\
\hline Volunteer AAP & AMC & Mollusk & Eastern & fanshell & $P E$ & & YR & Possible & $\mathrm{N}$ \\
\hline Fort Knox & TRADOC & Mollusk & Eastern & fanshell & $P E$ & ST & YR & Possible & $\mathrm{NH}$ \\
\hline Fort Gordon & TRADOC & Reptile & Eastern & Indlgo snake & FT & & YR & Possible & HR \\
\hline Camp Shelby & NGB & Reptile & Eastern & 1nd1go snake & ET & & YR & Possible & $\mathrm{R}$ \\
\hline Fort stewart & FORSCOM & Reptile & Eastern & Indigo snake & FT & & YR & Possible & $\mathrm{N}$ \\
\hline Fort Rucker & TRADOC & Reptile & Eastern & Indlgo snake & ET & & YR & Ext1rpated & $\mathrm{HR}$ \\
\hline Mississipp1 AAP & AMC & Reptile & Eastern 1 & 1ndlgo snake & ET & & YR & Possible & $\mathrm{R}$ \\
\hline Camp Blanding & NGB & Rept1le & Eastern 1 & Indigo snake & FT & & YR & L1kely & $\mathrm{N}$ \\
\hline Fort story & TRADOC & B1rd & Eastern & least tern & RSE & & B & Likely & $\mathrm{N}$ \\
\hline Fort Eustis & TRADOC & Bird & Eastern & least tern & RSE & & B & Likely & $\mathrm{N}$ \\
\hline Fort D1x & TRADOC & Bird & Eastern & least tern & $S E$ & & $\mathrm{~T}$ & Possible & $\mathrm{N}$ \\
\hline Bager AAP & AMC & Reptile & Eastern $\pi$ & massasauga & $\mathrm{C} 2$ & SE & YR & Possible & $\mathrm{N}$ \\
\hline Savanna AD & AMC & Reptile & Eastern $\pi$ & massasauga & $\mathrm{C} 2$ & & YR & Possible & $\mathrm{N}$ \\
\hline Ravenna AAP & AMC & Rept1le & Eastern $\pi$ & massasauga & C2 & & YR & Possible & $\mathrm{NH}$ \\
\hline Fort McCoy & FORSCOM & Rept1le & Eastern $n$ & massasauga & $\mathrm{C} 2$ & SE & YR & Possible & $\mathrm{N}$ \\
\hline U.S. M1l1tary Academy & Y USMA & Reptile & Eastern & mud turtle & ST & & YR & Possible & $\mathrm{R}$ \\
\hline Ravenna AAP & AMC & Mollusk & Eastern & pondmussel & SE & & YR & Possible & $\mathrm{N}$ \\
\hline Newport AAP & AMC & Fish & Eastern & sand darter & $\mathrm{C} 2$ & & YR & Possible & $\mathrm{N}$ \\
\hline Camp Atterbury & NGB & Fish & Eastern : & sand darter & $\mathrm{C} 2$ & & YR & Possible & $\mathrm{N}$ \\
\hline Fort Knox & TRADOC & Fish & Eastern & sand darter & $\mathrm{C} 2$ & & YR & Possible & $R$ \\
\hline Lexington/Bluegrass & AMC & Fish & Eastern : & sand darter & $\mathrm{C} 2$ & & YR & Possible & $\mathrm{N}$ \\
\hline Jefferson PG & AMC & Fish & Eastern : & sand darter & $\mathrm{C} 2$ & & YR & Possible & $\mathrm{N}$ \\
\hline Fort Devens & FORSCOM & Mamma 1 & Eastern : & small-footed bat & $\mathrm{C} 2$ & & E, M & Possible & $\mathrm{R}$ \\
\hline Fort Knox & TRADOC & Mamma 1 & Eastern & small-footed bat & $\mathrm{C} 2$ & SE & YR & Possible & $\mathrm{R}$ \\
\hline Camp Edwards & NGB & Mamma 1 & Eastern & small-footed bat & $\mathrm{C} 2$ & & $\mathrm{~F}, \mathrm{M}$ & Possible & $\mathrm{R}$ \\
\hline Fort D1x & TRADOC & Mamma 1 & Eastern & small-footed bat & $\mathrm{C} 2$ & & $\mathrm{~T}$ & Possible & $\mathrm{HR}$ \\
\hline Volunteer AAP & AMC & Mammal & Eastern : & small-footed bat & $\mathrm{C} 2$ & & M & Possible & $\mathrm{N}$ \\
\hline Lexington/Bluegrass & AMC & Mamma 1 & Eastern : & small-footed bat & $\mathrm{C} 2$ & & $F, M$ & Possible & $\mathrm{R}$ \\
\hline Fort George Meade & FORSCOM & Mammal & Eastern & smali-footed bat & $\mathrm{C} 2$ & & $\mathrm{M}$ & Possible & $\mathrm{R}$ \\
\hline Letterkenny AD & AMC & Mamma 1 & Eastern & small-footed bat & $\mathrm{C} 2$ & SE & M & Possible & $\mathrm{R}$ \\
\hline U.S. Military Academy & Y USMA & Mamma I & Eastern : & small-footed bat. & $\mathrm{C} 2$ & & B & Possible & $\mathrm{R}$ \\
\hline Aberdeen PG & AMC & Mamma 1 & Eastern & small-footed bat & $\mathrm{C} 2$ & & $M$ & Possible & $\mathrm{R}$ \\
\hline Fort Campbell & FORSCOM & Mamma 1 & Eastern & small-footed bat & $\mathrm{C} 2$ & & YR & Possible & $\mathrm{R}$ \\
\hline Camp Edwards & NGB & Amphiblan & Eastern & spadefoot toad & ST & & YR & Possible & $\mathrm{N}$ \\
\hline Fort Dix & TRADOC & Amph 1 blan & Eastern & tiger salamander & SE & & YR & Possible & $\mathrm{N}$ \\
\hline Fort knox & TRADOC & Mamma I & Eastern & woodrat & $\mathrm{C} 2$ & & YR & Possible & $\mathrm{N}$ \\
\hline Picatinny Arsenal & AMC & Mamma 1 & Eastern & woodrat & $\mathrm{C} 2$ & ST & YR & Current & \\
\hline Volunteer AAP & AMC & Mamma I & Eastern & woodrat & C2 & & YR & Possible & $\mathrm{R}$ \\
\hline Lexington/Bluegrass & AMC & Mamma 1 & Eastern & woodrat & $\mathrm{C} 2$ & & $Y R$ & Possible & $\mathrm{N}$ \\
\hline U.S. M1litary Academy & Y USMA & Mamma 1 & Eastern & woodrat & $\mathrm{C} 2$ & SE & YR & Current & \\
\hline Jollet AAP & AMC & Mollusk & Elephant & ear & ST & & YR & Possible & $\mathrm{N}$ \\
\hline Savanna $\mathrm{AD}$ & AMC & Mollusk & Elephant & ear & ST & & YR & Possible & $\mathrm{NH}$ \\
\hline Lexington/Bluegrass & AMC & Mamma 1 & Evening & bat & SE & & B & Possible & $\mathrm{R}$ \\
\hline Newport AAP & AMC & Mamma 1 & Evenlng & bat & SE & & B & Possible & $\mathrm{N}$ \\
\hline Jefferson PG & AMC & Mamma 1 & Evening & bat & $S E$ & & B & Possible & $\mathrm{R}$ \\
\hline Eort Campbell & FORSCOM & Mamma 1 & Evening & bat & SE & & B & Possible & $\mathrm{R}$ \\
\hline Camp Atterbury & NGB & Mamma 1 & Evening & bat & $S E$ & & B & Possible & $\mathrm{N}$ \\
\hline Indiana AAP & AMC & Mamma 1 & Evening & bat & $S E$ & & $F, M$ & Possible & $\mathrm{N}$ \\
\hline Fort Knox & TRADOC & Mamma 1 & Evening & bat & ST & & B & Possible & $\mathrm{R}$ \\
\hline Redstone Arsenal & AMC & Mollusk & Fanshel1 & & $\mathrm{C} 2$ & & YR & Possible & $\mathrm{NH}$ \\
\hline Newport AAP & AMC & Mollusk & Fanshell & & $\mathrm{PE}$ & & YR & Possible & $\mathrm{N}$ \\
\hline Newport AAP & AMC & Mollusk & Fat pocke & ketbook & $\mathrm{FE}$ & & YR & Possible & $\mathrm{N}$ \\
\hline Fort Knox & TRADOC & Mollusk & Fat pocke & etbook & EE & & YR & Possible & $\mathrm{NH}$ \\
\hline Radford AAP & AMC & Fish & Finescale & e saddled darter & $\mathrm{C} 2$ & & YR & Possible & $\mathrm{N}$ \\
\hline Anniston $\mathrm{AD}$ & AMC & Mollusk & Fine-line & ed pocketbook & $\mathrm{C} 2$ & & YR & Possible & $\mathrm{NH}$ \\
\hline Fort Mcclellan & TRADOC & Mollusk & Fine-1ine & ed pocketbook & $\mathrm{C} 2$ & & YR & Possible & $\mathrm{NH}$ \\
\hline Redstone Arsenal & AMC & Mollusk & Fine-raye & ed plgtoe & $\mathrm{FE}$ & & YR & Possible & $\mathrm{NH}$ \\
\hline Camp Blanding & NGB & Mammal & Florida & black bear & $\mathrm{C} 2$ & ST & $\mathrm{T}$ & Possible & $\mathrm{N}$ \\
\hline Camp Blanding & NGB & Mamma 1 & Florida & panther & $\mathrm{FE}$ & & YR & Unlikely & $\mathrm{HR}$ \\
\hline Camp shelby & NGB & Mamma 1 & Florida & panther & $\mathrm{FE}$ & & YR & Unllkely & $\mathrm{HR}$ \\
\hline Fort Gordon & TRADOC & Mamma 1 & Florida & panther & $\mathrm{FE}$ & & $\mathrm{T}$ & Unlikely & HR \\
\hline Fort Stewart & FORSCOM & Mamma 1 & Florida & panther & FE & & $\mathrm{T}$ & Posslble & HR \\
\hline Redstone Arsenal & AMC & Mamma l & Florida & panther & $\mathrm{EE}$ & & YR & Ext1rpated & $\mathrm{HR}$ \\
\hline Fort Rucker & TRADOC & Mamma 1 & Florida & panther & $F E$ & & YR & Extirpated & $\mathrm{HR}$ \\
\hline Mississipp1 AAP & AMC & Mamma 1 & Florida & panther & FE & & YR & Possible & $\mathrm{HR}$ \\
\hline Fort Benning & TRADOC & Mamma 1 & Florida & panther & $F E$ & & YR & Extirpated & $\mathrm{HR}$ \\
\hline Volunteer AAP & AMC & Mamma 1 & Florida & panther & $\mathrm{FE}$ & & YR & Possible & $\mathrm{HR}$ \\
\hline Fort Mcclellan & TRADOC & Mamma 1 & Florida & panther & EE & & YR & Extirpated & $\mathrm{HR}$ \\
\hline Anniston $A D$ & AMC & Mamma 1 & Florida & panther & $\mathrm{FE}$ & & YR & Ext1rpated & HR \\
\hline Fort Jackson & TRADOC. & Mamma 1 & Florida & panther & FE & & YR & Extirpated & $\mathrm{HR}$ \\
\hline Camp Blanding & NGB & B1rd & Florida s & scrub jay & FT & & YR & Current & \\
\hline Jollet AAP & AMC & Bird & Forster's & s tern & SE & & B & Former & $\mathrm{HR}$ \\
\hline Bager AAP & AMC & B1rd & Forster's & s tern & $S E$ & & $M$ & Possible & $\mathrm{R}$ \\
\hline M1ssiss1pp1 AAP & AMC & F1sh & Frecklebe & eliled madtom & $\mathrm{C} 2$ & SE & YR & Possible & $\mathrm{N}$ \\
\hline Camp Edwards & NGB & Insect & Gerhard's & $s$ underwing moth & ST & & & Current & \\
\hline Fort McCoy & FORSCOM & Insect & Giant car & rrion beetle & $\mathrm{FE}$ & & & Possible & $\mathrm{NH}$ \\
\hline
\end{tabular}


Appendix B (continued)

\begin{tabular}{|c|c|c|c|c|c|c|c|c|}
\hline Installation & МACOM & Taxon & Species & Status & Re & sidency & \multicolumn{2}{|c|}{ Occurrance } \\
\hline Fort McCoy & FORSCOM & Fish & G11t darter & ST & & $Y R$ & Possible & $\mathrm{N}$ \\
\hline Camp Santiago & NGB & Rept1le & Golden coqu 1 & FE & & YR & Possible & $\mathrm{N}$ \\
\hline Fort Campbel1 & FORSCOM & Bird & Golden eagle & SE & & w & Possible & $\mathrm{R}$ \\
\hline Fort Drum & FORSCOM & Bird & Golden eagle & SE & & $M$ & Possible & $\mathrm{R}$ \\
\hline Volunteer AAP & AMC & Blrd & Golden eagle & SE & & $\mathrm{T}$ & Possible & $\mathrm{N}$ \\
\hline Seneca $A D$ & AMC & B1rd & Golden eagle & SE & & M & Possible & $\mathbf{R}$ \\
\hline Fort Jackson & TRADOC & Blrd & Golden eagle & SE & & $\mathrm{T}$ & Possible & $\mathrm{R}$ \\
\hline U.S. M111tary Academy & y USMA & Bird & Golden eagle & SE & & M & Current & \\
\hline Camp Atterbury & NGB & Blrd & Golden-winged warbler & SE & & B & Possible & $\mathbf{R}$ \\
\hline Bager AAP & AMC & Fish & Goldeye & SE & & YR & Possible & $\mathrm{N}$ \\
\hline Fort Campbell & FORSCOM & Mollusk & Golf-st1ck pearly musse 1 & FE & & YR & Unllkely & $\mathrm{NH}$ \\
\hline Camp Blanding & NGB & Amphlbian & Gopher frog & $\mathrm{C2}$ & & YR & Current & \\
\hline Fort Rucker & TRADOC & Reptile & Gopher tortolse & $\mathrm{C2}$ & ST & YR & Extirpated & HR \\
\hline Camp Blanding & NGB & Reptile & Gopher tortolse & $\mathrm{C} 2$ & & YR & Current & \\
\hline Fort Stewart & FORSCOM & Reptile & Gopher tortolse & $\mathrm{C} 2$ & & YR & Current & \\
\hline Fort Gordon & TRADOC & Reptile & Gopher tortolse & $\mathrm{C} 2$ & & YR & Possible & HR \\
\hline Fort Benn1ng & TRADOC & Reptile & Gopher tortolse & $\mathrm{FE}$ & & YR & Current & \\
\hline Camp Shelby & NGB & Reptile & Gopher tortolse & FT & & YR & Current: & \\
\hline M1ssissippi AAP & AMC & Reptile & Gopher tortolse & FT & & YR & Possible & $\mathbf{R}$ \\
\hline Fort Campbell & FORSCOM & B1rd & Grasshopper sparrow & SE & & B & Possible & $\mathrm{N}$ \\
\hline Fort $\mathrm{DIx}$ & TRADOC & Bird & Grasshopper sparrow & ST & & B & Possible & $\mathrm{N}$ \\
\hline Letterkenny $A D$ & AMC & B1rd & Grasshopper sparrow & ST & & B & Current & \\
\hline Fort Indlantown Gap & FORSCOM & B1rd & Grasshopper sparrow & ST & & B & Possible & $\mathrm{N}$ \\
\hline M1lan AAP & AMC & Bird & Grasshopper sparrow & ST & & B & Possible & $\mathrm{N}$ \\
\hline P1catinny Arsenal & AMC & Bird & Grasshopper sparrow & ST & & B & Possibie & $\mathrm{N}$ \\
\hline Jefferson PG & AMC & Mamma 1. & Gray bat & FE & & PB & Possible & $\mathrm{N}$ \\
\hline Lexington/Bluegrass & AMC & Mammal & Gray bat & $\mathrm{FE}$ & & F & Possible & $\ddot{N}$ \\
\hline M1lan AAP & AMC & Mamma 1 & Gray bat & $\mathrm{FE}$ & & $\mathrm{E}, \mathrm{M}$ & Possible & $\mathrm{R}$ \\
\hline Anniston $A D$ & AMC & Mammal & Gray bat & $\mathrm{EE}$ & & $\mathrm{F}, \mathrm{M}$ & Possible & HR \\
\hline Volunteer AAP & AMC & Mammal & Gray bat & $\mathrm{FE}$ & & F & Possible & $\mathrm{N}$ \\
\hline Camp Atterbury & NGB & Mamma 1 & Gray bat & $\mathrm{FE}$ & & $\mathrm{PB}$ & Possible & $\mathrm{N}$ \\
\hline Fort knox & TRADOC & Mammal & Gray bat & $\mathrm{FE}$ & & YR & Current & \\
\hline Fort McClellan & TRADOC & Mamma I & Gray bat & $\mathrm{FE}$ & & $\mathrm{T}$ & Possible & $\mathbf{R}$ \\
\hline Redstone Arsenal & AMC & Mamma 1 & Gray bat & $\mathrm{EE}$ & & $\mathrm{F}$ & Possible & $\mathrm{N}$ \\
\hline Indlana AAP & AMC & Mamma I & Gray bat & $\mathrm{FE}$ & & PB & Possible & $\mathrm{N}$ \\
\hline Fort Campbell & EORSCOM & Mamma 1 & Gray bat & $\mathrm{EE}$ & & F & Likely & $\mathrm{N}$ \\
\hline Milan AAP & AMC & B1rd & Great blue heron & ST & & YR & Possible & $\mathrm{R}$ \\
\hline Volunteer AAP & AMC & Bird & Great blue heron & ST & & YR & Possible & $\mathrm{N}$ \\
\hline Fort Campbel1 & FORSCOM & Bird & Great blue heron & ST & & YR & Possible & $\mathrm{R}$ \\
\hline Fort D1x & TRADOC & B1rd & Great blue heron & ST & . & YR & Possible & $\mathrm{N}$ \\
\hline Plcatinny Arsenal & AMC & B1rd & Great blue heron & ST & & YR & Current & \\
\hline Jefferson PG & AMC & B1rd & Great egret & SE & & M & Possible & $\mathrm{R}$ \\
\hline Jollet AAP & AMC & B1rd & Great egret & $S E$ & & B & Likely & $\mathrm{N}$ \\
\hline Savanna $A D$ & AMC & Bird & Great egret & SE & & B & Current & \\
\hline Fort Knox & TRADOC & B1rd & Great egret & $S E$ & & $\mathrm{~T}$ & Possible & $\mathbf{R}$ \\
\hline Newport AAP & AMC & B1rd & Great eqret & SE & & $\mathrm{PB}$ & Possible & $\mathrm{R}$ \\
\hline Indlana AAP & AMC & Bird & Great eqret & SE & & M & Possible & R \\
\hline Camp Atterbury & NGB & Bird & Great egret & SE & & PB & Possible & $\ddot{R}$ \\
\hline Fort Campbell & FORSCOM & B1rd & Great egret & SE & & B, $\mathrm{PB}$ & Possible & $\mathrm{N}$ \\
\hline Fort MeCoy & FORSCOM & B1rd & Great egret & ST & & $\mathrm{B}$ & Possible & $\mathrm{N}$ \\
\hline Bager AAP & AMC & Blrd & Great egret & ST & & B & Possible & $\mathrm{N}$ \\
\hline Sunny Point MT & MTMC & Rept1le & Green turtle & FE & & Adjacent & Possible & $\mathrm{R}$ \\
\hline Fort story & TRADOC & Reptile & Green turtle & FT & & Adjacent & Possible & $\mathrm{N}$ \\
\hline Mississipp1 AAP & AMC & Fish & Gulf sturgeon & $\mathrm{C} 2$ & & YR & Likely & R \\
\hline Fort Eustis & TRADOC & B1rd & Gull-billed tern & RSE & & $\mathrm{T}$ & Possible & $\mathrm{R}$ \\
\hline Fort story & TRADOC & B1rd & Gull-billed tern & RSE & & T & Possible & $\mathrm{R}$ \\
\hline Sunny Point MT & MTMC & Rept1le & Hawksbill turtle & $\mathrm{FE}$ & & Adjacent & Possible & R \\
\hline Plcatinny Arsenal & AMC & Insect & Hebard's noctuld moth & $\mathrm{C} 2$ & & & Possible & $\mathrm{N}$ \\
\hline Aberdeen PG & AMC & Amphibian & Hellbender & $\mathrm{C} 2$ & SE & YR & Possible & R \\
\hline Fort Knox & TRADOC & Amphiblan & Hellbender & $\mathrm{C} 2$ & & YR & Possible & $\mathrm{R}$ \\
\hline Volunteer AAP & AMC & Amphiblan & Hellbender & $\mathrm{C} 2$ & & $\mathrm{YR}$ & Possible & $\mathrm{R}$ \\
\hline Radford AAP & AMC & Amphibian & Hellbender & $\mathrm{C2}$ & & YR & Possible & $\mathrm{N}$ \\
\hline Lexington/Bluegrass & AMC & Amph1bian & Hellbender & $\mathrm{C2}$ & & YR & Possible & $\mathrm{R}$ \\
\hline Indiana AAP & AMC & Amphlblan & Hellbender & $\mathrm{C2}$ & SE & YR & Current & \\
\hline Fort Campbel1 & FORSCOM & Amphlbian & Hellbender & $\mathrm{C} 2$ & & YR & Possible & $\mathrm{N}$ \\
\hline Fort story & TRADOC & Bird & Henslow's sparrow & RSE & & B & Possible & $\mathrm{N}$ \\
\hline Fort Pickett & FORSCOM & B1rd & Henslow's sparrow & RSE & & B & Possible & $\mathrm{R}$ \\
\hline Fort Lee & TRADOC & Bird & Henslow's sparrow & RSE & & B & Possible & $\mathrm{R}$ \\
\hline Fort Belvoir & MDW & Bird & Henslow's sparrow & RSE & & B & Possible & $\mathrm{R}$ \\
\hline Fort Devens & FORSCOM & B1rd & Henslow's sparrow & $\mathrm{SE}$ & & B & Possible & $\mathrm{R}$ \\
\hline Camp Edwards & NGB & B1rd & Henslow's sparrow & SE & & B & Possible & $\mathrm{R}$ \\
\hline Jefferson PG & AMC & B1rd & Henslow's sparrow & ST & & $\mathrm{B}$ & Possible & $\mathrm{R}$ \\
\hline Camp Atterbury & NGB & B1rd & Henslow's sparrow & ST & & B & Possible & R \\
\hline Jollet AAP & AMC & B1rd & Henslow's sparrow & ST & & B & Likely & $\mathrm{N}$ \\
\hline Letterkenny $A D$ & AMC & Bird & Henslow's sparrow & ST & & B & Current & \\
\hline Savanna $A D$ & AMC & Mollusk & Higgins eye pearly mussel & $\mathrm{FE}$ & & $Y R$ & Possible & $\mathrm{N}$ \\
\hline Jollet AAP & AMC & Mollusk & Higgins eye pearly mussel & $S E$ & & YR & Possible & $\mathrm{N}$ \\
\hline Fort Knox & TRADOC & Blrd & Hooded merganser & SE & & W & Possible & R \\
\hline Fort Campbel1 & FORSCOM & B1rd & Hooded merganser & SE & & YR & Possible & $\mathrm{N}$ \\
\hline Camp Atterbury & NGB & Mamma 1 & Indlana bat & $\mathrm{FE}$ & & $\mathrm{M}$ & Possible & $\mathrm{N}$ \\
\hline Savanna $A D$ & AMC & Mamma 1 & Indiana bat & FE & & B, $\mathrm{F}$ & Possible & $\mathrm{N}$ \\
\hline Fort Gordon & TRADOC & Mamma 1 & Indlana bat & $\mathrm{FE}$ & & $\mathrm{F}, \mathrm{M}$ & Possible & R \\
\hline Newport AAP & AMC & Mamma 1 & Indlana bat & $\mathrm{FE}$ & & $M$ & Possible & $\mathrm{N}$ \\
\hline Letterkenny $A D$ & AMC & Mamma 1 & Indiana bat & $\mathrm{FE}$ & & $M$ & Possible & $\mathrm{R}$ \\
\hline Radford AAP & AMC & Mamma 1 & Indlana bat & $\mathrm{FE}$ & & $\mathrm{T}$ & Possible & $\mathrm{R}$ \\
\hline Fort Benning & TRADOC & Mamma 1 & Indlana bat & $\mathrm{FE}$ & & F, M & Possible & $\mathrm{R}$ \\
\hline
\end{tabular}




\begin{tabular}{|c|c|c|c|}
\hline Installation & IACOM & Taxon & Species \\
\hline Jollet AAP & AMC & Mamma 1 & Indiana bat \\
\hline Lexington/Bluegrass & AMC & Mamma 1 & Indlana bat \\
\hline Fort Rucker & TRADOC & Mamma I & Indiana bat \\
\hline Fort Indlantown Gap & FORSCOM & Mamma I & Indiana bat \\
\hline Jefferson PG & AMC & Mamma I & Indiana bat \\
\hline Ravenna AAP & AMC & Mamma 1 & Indiana bat \\
\hline Redstone Arsenal & AMC & Mamma 1 & Indiana bat \\
\hline U.S. Military Academy & USMA & Mamma I & Indiana bat \\
\hline Volunteer AAP & AMC & Mamma I & Indiana bat \\
\hline Indiana AAP & AMC & Mamma 1 & Indiana bat \\
\hline Milan AAP & AMC & Mamma 1 & Indiana bat \\
\hline Fort Drum & FORSCOM & Mamma 1 & Indlana bat \\
\hline Fort Mcclellan & TRADOC & Mamma 1 & Indiana bat \\
\hline Fort Devens & FORSCOM & Mamma 1 & Indiana bat \\
\hline Anniston $A D$ & AMC & Mamma 1 & Indiana bat \\
\hline Fort Campbel1 & FORSCOM & Mamma 1 & Indiana bat \\
\hline Seneca $A D$ & AMC & Mamma 1 & Indiana bat \\
\hline Volunteer AAP & AMC & B1rd & Interior least tern \\
\hline Indlana AAP & AMC & B1rd & - Interior least tern \\
\hline Fort Knox & TRADOC & Bird & Interior least tern \\
\hline M1lan AAP & AMC & B1rd & Interfor least tern \\
\hline Fort Campbell & FORSCOM & Bird & Interior least tern \\
\hline U.S. M11itary Academy & USMA & B1rd & Interior least tern \\
\hline Fort Bragg & FORSCOM & B1rd & Ivory-b11led woodpecker \\
\hline Fort Gordon & TRADOC & Bird & Ivory-billed woodpecker \\
\hline Fort Campbel1 & FORSCOM & B1rd & Ivory-billed woodpecker \\
\hline Mississippi AAP & AMC & B1rd & Ivory-billed woodpecker \\
\hline Fort Knox & TRADOC & Bird & Ivory-b11led woodpecker \\
\hline Camp Blanding & NGB & B1rd & Ivory-b11led woodpecker \\
\hline Milan AAP & AMC & Bird & Ivory-billed woodpecker \\
\hline Fort Jackson & TRADOC & B1rd & Ivory-b1lled woodpecker \\
\hline Sunny Point MT & MTMC & Bird & Ivory-billed woodpecker \\
\hline Fort stewart & FORSCOM & B1rd & Ivory-bllled woodpecker \\
\hline Fort Rucker & TRADOC & Bird & Ivory-billed woodpecker \\
\hline Fort Mcclellan & TRADOC & Mollusk & Judge Taft's mussel \\
\hline Anniston $A D$ & AMC & Mollusk & Judge Ta1t's mussel \\
\hline Radford AAP & AMC & F1sh & Kanawha minnow \\
\hline Fort McCoy & FORSCOM & Insect & Karner blue butterfly \\
\hline Newport AAP & AMC & Insect & Karner blue butterfly \\
\hline Fort story & TRADOC & Rept 110 & Kemp's ridley sea turtle \\
\hline Fort stewart & FORSCOM & Rept11e & Kemp's ridley sea turtle \\
\hline Sunny Point MT & MTMC & Rept1le & Kemp's ridley sea turtle \\
\hline Bager AAP & AMC & B1rd & Kentucky warbler \\
\hline Fort McCoy & FORSCOM & B1rd & Kentucky warbler \\
\hline Jefferson PG & AMC & B1rd & K1ng rail \\
\hline Camp Atterbury & NGB & B1rd & Klng rall \\
\hline Ravenna AAP & AMC & B1rd & King rall \\
\hline Fort Knox & TRADOC & Blrd & King rail \\
\hline Milan AAP & AMC & B1rd & K1ng ra 11 \\
\hline Fort Campbell & FORSCOM & Blrd & King rall \\
\hline Volunteer AAP & AMC & Bird & King rall \\
\hline Camp Grayl1ng & NGB & B1rd & King rail \\
\hline Camp Edwards & NGB & B1rd & King rall \\
\hline Camp Atterbury & NGB & Reptile & Kirtland's snake \\
\hline Newport AAP & AMC & Reptile & Klrtland's snake \\
\hline Jollet AAP & AMC & Rept11e & K1rtland's snake \\
\hline Indlana AAP & AMC & Reptile & Kirtland's snake \\
\hline Jefferson PG & AMC & Reptile & Kirtland's snake \\
\hline Fort Knox & TRADOC & Reptile & Klrtland's snake \\
\hline Fort Bragg & FORSCOM & Bird & Kirtland's warbler \\
\hline Fort George Meade & FORSCOM & Bird & Kirtland's warbler \\
\hline Sunny Polnt MT & MTMC & Bird & Kirtland's warbler \\
\hline Camp Grayling & NGB & B1rd & Klrtland's warbler \\
\hline Fort Jackson & TRADOC & Bird & K1rtland's warbler \\
\hline Aberdeen PG & AMC & B1rd & K1rtland's warbler \\
\hline Fort stewart & FORSCOM & Bird & K1rtland's warbler \\
\hline Savanna $A D$ & AMC & Fish & Lake sturgeon \\
\hline Bager AAP & AMC & Fish & Lake sturgeon \\
\hline Fort Campbel1 & EORSCOM & Fish & Lake sturgeon \\
\hline Fort knox & TRADOC & B1rd & Lark sparrow \\
\hline Fort Campbel1 & FORSCOM & B1rd & Lark sparrow \\
\hline Lexington/Bluegrass & AMC & B1rd & Lark sparrow \\
\hline Fort Campbell & EORSCOM & B1rd & Least bittern \\
\hline Jollet AAP & AMC & B1rd & Least bittern \\
\hline Savanna $A D$ & AMC & B1rd & Least bittern \\
\hline Fort Knox & TRADOC & B1rd & Least bittern \\
\hline Fort Devens & FORSCOM & B1rd & Least blttern \\
\hline Volunteer AAP & AMC & B1rd & Least bittern \\
\hline Milan AAP & AMC & B1rd & Least blttern \\
\hline Jollet AAP & AMC & Bird & Least tern \\
\hline Sunny Point MT & MTMC & Rept11e & Leatherback turtle \\
\hline Fort D1X & TRADOC & Insect & Lemmer's pinnion moth \\
\hline Fort Benning & TRADOC & Mollusk & Lined pocketbook \\
\hline Fort Campbel1 & FORSCOM & B1rd & Little blue heron \\
\hline Jollet AAP & AMC & Bird & L1ttle blue heron \\
\hline Savanna $A D$ & AMC & B1rd & Little blue heron \\
\hline
\end{tabular}

\begin{tabular}{|c|c|c|c|c|}
\hline Status & & Residency & Occurranc & \\
\hline $\mathrm{FE}$ & & $B, F$ & Possible & R \\
\hline $\mathrm{FE}$ & & F. M & Possible & $\mathrm{N}$ \\
\hline $\mathrm{FE}$ & & B, E & Possible & $\mathrm{N}$ \\
\hline$F E$ & & M & Posslble & $\mathbf{R}$ \\
\hline FE & & F, M & Possible & $\mathrm{N}$ \\
\hline FE & & F & Possible & $\mathbf{R}$ \\
\hline FE & & $F$ & Possible & $\mathrm{N}$ \\
\hline$F E$ & & $\mathrm{~T}$ & Possible & $\mathrm{N}$ \\
\hline FE & & $F$ & Possible & $\mathrm{R}$ \\
\hline $\mathrm{FE}$ & & F, M & Possible & $\mathrm{N}$ \\
\hline $\mathrm{FE}$ & & $\mathrm{F}, \mathrm{M}$ & Possible & $\mathrm{R}$ \\
\hline FE & & $\mathrm{F}, \mathrm{M}$ & Possible & $\mathrm{R}$ \\
\hline $\mathrm{FE}$ & & $B, F, M$ & Possible & $\mathrm{R}$ \\
\hline $\mathrm{FE}$ & & F, M & Possible & $\mathrm{R}$ \\
\hline $\mathrm{FE}$ & & $B, F, M$ & Possible & $\mathrm{N}$ \\
\hline $\mathrm{FE}$ & & $B, F, M$ & Likely & $\mathrm{N}$ \\
\hline FE & & T & Possible & $\mathrm{R}$ \\
\hline FE & & T & Possible & $\mathrm{N}$ \\
\hline $\mathrm{FE}$ & & $T$ & Possible & $\mathrm{N}$ \\
\hline $\mathrm{FE}$ & & $\mathrm{T}$ & Possible & $\mathrm{R}$ \\
\hline FE & & T & Possible & R \\
\hline $\mathrm{FE}$ & & $\mathrm{T}$ & Possible & $\mathbf{R}$ \\
\hline$S E$ & & $T$ & Possible & R \\
\hline FE & & YR & Ext1rpated & HR \\
\hline $\mathrm{FE}$ & & YR & Extirpated & HR \\
\hline$F E$ & & YR & Ext1rpated & HR \\
\hline $\mathrm{FE}$ & & YR & Ext1rpated & HR \\
\hline$F E$ & & YR & Extirpated & HR \\
\hline$F E$ & & YR & Extirpated & HR \\
\hline $\mathrm{FE}$ & & YR & Possible & HR \\
\hline $\mathrm{FE}$ & & YR & Ext1rpated & HR \\
\hline FE. & & YR & Ext1rpated & HR \\
\hline $\mathrm{FE}$ & & YR & Ext1rpated & HR \\
\hline $\mathrm{FE}$ & & YR & Extirpated & HR \\
\hline FE & & YR & Possible & NH \\
\hline$\overline{F E}$ & & YR & Possible & $\mathrm{NH}$ \\
\hline $\mathrm{C} 2$ & & $Y R$ & Possible & $\mathrm{N}$ \\
\hline C2 & & & Current & \\
\hline $\mathrm{C2}$ & SE & YR & Possible & $\mathrm{N}$ \\
\hline $\mathrm{FE}$ & & Adjacent & Possible & $\mathrm{R}$ \\
\hline FE & & Adfacent & Possible & $\mathrm{R}$ \\
\hline $\mathrm{FE}$ & & AdJacent & Possible & $\mathrm{R}$ \\
\hline ST & & $M$ & Possible & R \\
\hline ST & & M & Current & \\
\hline SE & & B & Possible & $\mathrm{R}$ \\
\hline SE & & B & Current & \\
\hline SE & & B & Possible & NH \\
\hline $\mathrm{SE}$ & & B & Possible & $\mathrm{N}$ \\
\hline SE & & B & Possible & $\mathrm{N}$ \\
\hline SE & & YR & Posslble & $\mathrm{R}$ \\
\hline SE & & B & Possible & $\mathrm{N}$ \\
\hline SE & & B & Possible & $\mathbf{R}$ \\
\hline ST & & YR & Possible & $\mathrm{R}$ \\
\hline C2 & & YR & Possible & HR \\
\hline $\mathrm{C} 2$ & ST & $\mathrm{YR}$ & Possible & $\mathrm{R}$ \\
\hline C2 & & YR & Possible & $\mathrm{N}$ \\
\hline $\mathrm{C2}$ & ST & YR & Possible & $\mathrm{N}$ \\
\hline $\mathrm{C2}$ & ST & YR & Current & \\
\hline SE & & YR & Possible & $\mathrm{N}$ \\
\hline FE & & M & Possible & $\mathrm{R}$ \\
\hline $\mathrm{FE}$ & & $M$ & Possible & R \\
\hline $\mathrm{FE}$ & & M & Possible & $\mathrm{N}$ \\
\hline $\mathrm{FE}$ & & B & Current & \\
\hline $\mathrm{FE}$ & & M & Possible & $\mathrm{N}$ \\
\hline $\mathrm{FE}$ & & M & Possible & $\mathrm{R}$ \\
\hline $\mathrm{FE}$ & & M & Possible & $\mathrm{R}$ \\
\hline $\mathrm{C} 2$ & ST & YR & Possible & $\mathrm{N}$ \\
\hline $\mathrm{C} 2$ & & YR & Unlikely & $\mathrm{N}$ \\
\hline C2 & SE & Adjacent & Possible & $\mathrm{N}$ \\
\hline $\mathrm{SE}$ & & B & Possible & $\mathrm{R}$ \\
\hline SE & & B & Possible & $\mathrm{N}$ \\
\hline SE & & B & Possible & $\mathrm{N}$ \\
\hline$S E$ & & T & Possible & $\ddot{N}$ \\
\hline $\mathrm{SE}$ & & B & Possible & $\mathrm{R}$ \\
\hline SE & & $B$ & Possible & $\mathbf{R}$ \\
\hline SE & & B & Possible & $\mathrm{N}$ \\
\hline ST & & $B$ & Possible & $\mathrm{N}$ \\
\hline sT & & B & Possible & $\mathrm{N}$ \\
\hline ST & & $T$ & Possible & $\mathrm{R}$ \\
\hline FE & & PB & Possible & $\mathrm{R}$ \\
\hline FE & & Adjacent & Possible & $\mathrm{R}$ \\
\hline $\mathrm{C} 2$ & & & Possible & $\mathbf{R}$ \\
\hline $\mathrm{C2}$ & & YR & Possible & $\mathrm{N}$ \\
\hline SE & & PB, F & Possible & $\mathrm{N}$ \\
\hline $\mathrm{SE}$ & & PB & Possible & $\mathrm{N}$ \\
\hline $\mathrm{SE}$ & & M & Possible & $\mathbf{R}$ \\
\hline
\end{tabular}




\section{Appendix B (continued)}

\begin{tabular}{|c|c|c|c|c|c|c|c|c|c|}
\hline Installation & МACOM & Taxon & Species & & Status & & esidency & Occurrance & \\
\hline Fort Knox & TRADOC & Bird & Little bl & Iue heron & SE & & $\mathrm{sR}^{\mathrm{T}}$ & $\begin{array}{l}\text { Possible } \\
\text { Possible }\end{array}$ & $\underset{N}{N}$ \\
\hline $\begin{array}{l}\text { Fort Story } \\
\text { Sunny Point MT }\end{array}$ & $\begin{array}{l}\text { TRADOC } \\
\text { MTMC }\end{array}$ & $\begin{array}{l}\text { Reptile } \\
\text { Reptile }\end{array}$ & $\begin{array}{l}\text { Loggerhea } \\
\text { Loggerhea }\end{array}$ & $\begin{array}{l}\text { ad sea turtie } \\
\text { ad sea turtie }\end{array}$ & $\begin{array}{l}\text { FT } \\
\text { FT }\end{array}$ & & $\begin{array}{l}\text { SR } \\
\text { Adjacent }\end{array}$ & $\begin{array}{l}\text { Possible } \\
\text { Possible }\end{array}$ & $\begin{array}{l}\mathrm{N} \\
\mathrm{N}\end{array}$ \\
\hline $\begin{array}{l}\text { Sunny Polnt MT } \\
\text { Fort Stewart }\end{array}$ & $\begin{array}{l}\text { MTMC } \\
\text { FORSCOM }\end{array}$ & $\begin{array}{l}\text { Reptile } \\
\text { Rept1le }\end{array}$ & Loggerhea & ad sea turtle & FT & & Adjacent & Possible & \\
\hline PlcatInny Arsenal & AMC & Amphiblan & Longta 11 & salamander & ST & & $Y R$ & Possible & $\hat{N}$ \\
\hline Savanna $A D$ & AMC & B1rd & Long-eare & ed ow 1 & SE & & M & Possible & \\
\hline Newport AAP & AMC & Mollusk & Long-sol1 & id & SE & & YR & Possible & $\mathrm{N}$ \\
\hline Indlana AAP & AMC & Mollusk & Long-sol1 & & SE & & YR & Possible & \\
\hline Fort knox & TRADOC & Mollusk & Loulsvill & le crayfish & $\mathrm{c2} 2$ & SE & $\mathrm{YR}$ & Possible & \\
\hline Mississ1pp1 AAP & AMC & Mamma I & Louslana & black bear & c1 & & YR & Possible & R \\
\hline Sunny Point MT & MTMC & Mollusk & Magnifica & ant ramshorn & $\mathrm{c} 2$ & $S E$ & $Y R$ & Current & \\
\hline Fort Devens & FORSCOM & Amphlbian & Marbleds & salamander & ST & & YR & Possible & $\mathbf{R}$ \\
\hline Camp Edwards & NGB & Amphibian & Marbled $s$ & salamander & ST & & YR & Possible & $\mathrm{N}$ \\
\hline Aberdeen PG & AMC & Fish & Maryland & darter & $\mathrm{FE}$ & & YR & Current & \\
\hline Seneca $A D$ & AMC & Reptile & Massasaug & & SE & & YR & Possible & \\
\hline Camp Grayling & NGB & Bird & Merlin & & ST & & T & Possible & \\
\hline Fort George Meade & FORSCOM & Bird & Migrant 1 & loggerhead shrike & $\mathrm{C} 2$ & SE & $\mathrm{YR}$ & Possible & \\
\hline Aberdeen PG & AMC & Bird & Migrant 1 & loggerhead shrike & C2 & SE & YR & Possible & \\
\hline Jefferson PG & AMC & Bird & Migrant 1 & loggerhead shrike & C2 & SE & B & Possible & \\
\hline Savanna AD & AMC & B1rd & Migrant 1 & loggerhead shrike & C2 & ST & YR & Possible & \\
\hline Fort D1x & TRADOC & B1rd & Migrant-1 & loggerhead shrike & $\mathrm{C} 2$ & SE & w & Possible & \\
\hline Fort knox & TRADOC & B1rd & Migrant 1 & loggerhead shrike & C2 & & $\mathrm{YR}$ & Possible & \\
\hline Fort Campbe11 & FORSCOM & B1rd & Mlgrant 1 & loggerhead shrike & $\mathrm{c} 2$ & & YR & Possible & \\
\hline Fort Plckett & FORSCOM & Bird & Migrant 1 & loggerhead shrike & c2 & SE & B & Possible & \\
\hline Jollet AAP & AMC & B1rd & Migrant 1 & loggerhead shrike & C2 & ST & B & Current & \\
\hline Fort Belvolr & MDW & Bird & Migrant 1 & loggerhead shrike & C2 & SE & B & Possible & \\
\hline Lexington/Bluegrass & AMC & B1rd & Migrant 1 & loggerhead shrike & $\mathrm{C2}$ & & YR & Possible & \\
\hline Camp Grayling & NGB & Bird & Migrant 1 & loggerhead shrike & C2 & SE & B & Unlikely & \\
\hline Camp Edwards & NGB & B1rd & Migrant 1 & loggerhead shrike & $\mathrm{c2}$ & & M & Possible & \\
\hline Indiana AAP & AMC & B1rd & Migrant 1 & loggerhead shrike & c2 & SE & B & Possi & $\mathrm{NH}$ \\
\hline Camp Atterbury & NGB & B1rd & Migrant 1 & loggerhead shrike & $\mathrm{C2}$ & & M & Possib & \\
\hline U.S. M111tary Academy & Y USMA & Bird & Migrant 1 & loggerhead shrike & C2 & & M & Possible & \\
\hline Fort Lee & TRADOC & Bird & Mlgrant L & Loggerhead shrike & C2 & $\mathrm{SE}$ & B & Possible & \\
\hline Radford AAP & AMC & Bird & Mlgrant 1 & loggerhead shrike & C2 & SE & YR & Possible & \\
\hline Fort McCoy & FORSCOM & B1rd & Migrant 1 & loggerhead shrike & $\mathrm{C} 2$ & $S E$ & B & Possible & \\
\hline Newport AAP & AMC & B1rd & Migrant 1 & loggerhead shrike & C2 & $S E$ & B & Possible & \\
\hline Bager AAP & AMC & B1rd & MIgrant 1 & loggerhead shrike & C2 2 & $\mathrm{SE}$ & B & Possible & HR \\
\hline y Arsenal & AMC & Insect & Mitchell' & s satyr butterfly & c2 & & & Extirpated & $\mathrm{NH}$ \\
\hline Ravenna AAP & AMC & Fish & Mountain & brook lamprey & SE & & YR & Possible & \\
\hline Fort D1x & TRADOC & Mamma l & Mountain & $110 n$ & $\mathrm{FE}$ & & YR & Ext1rpated & $\mathrm{R}$ \\
\hline U.S. M1litary Academy & YS USA & Mamma 1 & Mountain & $110 n$ & $\mathrm{FE}$ & & YR & Ext1rpated & HR \\
\hline Fort Drum & FORSCOM & Mamma I & Mountain & $110 n$ & $\mathrm{FE}$ & & YR & Ext1rpated & $\mathrm{HR}$ \\
\hline P1cat1nny Arsenal & AMC & Mammal & Mountain & $110 \mathrm{n}$ & $\mathrm{FE}$ & & YR & Ext1rpated & HR \\
\hline Seneca AD & AMC & Mamma 1 & Mounta1n & $110 n$ & $\mathrm{EE}$ & & YR & Extir & $\mathrm{HR}$ \\
\hline Fort Dix & TRADOC & Amphiblan & Mud salam & nander & $\mathrm{S}^{\text {? }}$. & & YR & Poss & R \\
\hline Radford AAP & AMC & Amphlblan & Mudpuppy & & c. & & YR & & \\
\hline Camp Edwards & NGB & Mamma 1 & New Engla & and cottonta11 & $\mathrm{C} 2$ & & YR & Possible & \\
\hline Fort Devens & FORSCOM & Marmal & New Engla & and cottontall & C2 & & YR & Possible & $\mathrm{R}$ \\
\hline Fort D1x & TRADOC & Mamma 1 & New Engla & and cottontall & C2 & & YR & Possible & \\
\hline Plcatinny Arsenal & AMC & Mamma I & New Engla & and cottontall & C2 & & $\mathrm{YR}$ & Possible & $\mathrm{R}$ \\
\hline $\begin{array}{l}\text { Fort Knox } \\
\text { Fortide }\end{array}$ & TRADOC & F1sh & Northern & cavefish & $\mathrm{c} 2$ & & YR & Current & \\
\hline U.S. M1litary Academy & Y USMA & Amphibian & Northern & cricket frog & ST & & YR & Possible & $\mathrm{N}$ \\
\hline Picatinny Arsenal & AMC & Bird & Northern & goshawk & ST & & YR & Current & \\
\hline Fort D1x & TRADOC & Bird & Northern & goshawk & ST & & $\mathrm{T}$ & Possible & $\mathrm{R}$ \\
\hline Radford AAP & AMC & B1rd & Northern & harrier & RSE & & $\mathrm{T}$ & Possible & \\
\hline Fort Eustis & TRADOC & B1rd & Northern & harrier & RS: & & $\mathrm{M}$ & Poss 1 & $\mathrm{R}$ \\
\hline Fort Pickett & FORSCOM & B1rd & Northern & harrier & RS & & M & Poss & R \\
\hline Fort Lee & TRADOC & B1rd & Northern & harrier & RS & & $\mathrm{T}$ & & \\
\hline Fort story & TRADOC & Bird & Northern & harrier & RS & & $\mathrm{M}$ & le & $\mathrm{HR}$ \\
\hline Fort Belvolr & MDW & B1rd & Northern & harrler & RSE & & M & & $\mathrm{R}$ \\
\hline Indlana AAP & AMC & B1rd & Northern & harrier & $S E$ & & YR & & \\
\hline P1catinny Arsenal & AN & B1rd & Northern & harrier & SE & & $\mathrm{M}$ & Curre & \\
\hline Sava & AM & B1rd & Northern & harrier & SE & & $Y R$ & Possible & \\
\hline AAP & & B1. & Northern & harrier & SE & & YR & Possible & $\mathrm{R}$ \\
\hline Ravenn & AM & Bir & Northern & harrier & SE & & B & Possible & $\mathrm{N}$ \\
\hline Jollet AAP & & & Northern & harrier & si & & B & Current & \\
\hline Jefferson PG & AN & Bi. & Northern & harrier & SE & & YR & Possi & $\mathbf{R}$ \\
\hline Fort D1x & DOC & & Northern & harrier & SE & & YR & Poss: & $\mathrm{N}$ \\
\hline Camp Edwards & NGB & $B 1:$ & Northern & harrler & ST & & YR & & $\mathrm{N}$ \\
\hline Fort Devens & FORSCOM & Bir & Northern & harrier & ST & & $\mathrm{T}$ & & $\mathrm{R}$ \\
\hline Volunteer AAP & AMC & B1rd & Northern & harrler & ST & & $\mathrm{T}$ & & \\
\hline Fort Drum & EORSCOM & Bird & Northern & harrier & ST & & B & & $\mathrm{R}$ \\
\hline Mila & AMC & B1rd & Northern & harrier & ST & & I & & \\
\hline cbury & NG & B1r & Northern & harrier & ST & & YR & Curre & \\
\hline bell & SCOM & B1. & Northern & harrier & ST & & w & Possit & $\mathrm{N}$ \\
\hline Seneca $A D$ & AM & & Northern & harrier & sT & & M & Possible & $\mathbf{R}$ \\
\hline U.S. MIlltary Academy & ay us & B1: & Northern & harrier & ST & & M & Current & \\
\hline Camp Edwards & NG & & Northern & parula & ST & & B & Possible & $\mathrm{R}$ \\
\hline Fort Campbell & & & Northern & pine snake & c2 & $\mathbf{s}$ & YR & Poss 1 & \\
\hline Fort Dix & TRADOC & Rept1le & Northern & pine snak & $\mathrm{c} 2$ & s & YR & & \\
\hline Bager AAP & AMC & Reptile & Northern & ribbon snake & SE & & YR & & \\
\hline Newport AAP & AMC & Mollusk & Northern & riffleshell & C2 & SE & YR & Poss. & $\mathrm{N}$ \\
\hline Ravenna AAP & & B1rd & Northern & waterthrush & SE & & B & Possible & $\mathrm{N}$ \\
\hline Fort Knox & TRADOC & Mollusk & Onyx rock & ksna11 & $\mathrm{c} 2$ & & YR & Possible & $\mathrm{NH}$ \\
\hline Volunteer AAP & AMC & Mollusk & Onyx rock & knall & C2 & SE & YR & Unlikely & NH \\
\hline Indlana AAP & AMC & Mollusk & Orange-fo & ooted pearly mussel & $\mathrm{FE}$ & & YR & Ext1rpated & \\
\hline
\end{tabular}




\begin{tabular}{|c|c|c|c|c|c|c|c|c|}
\hline Installation & AACOM & Taxon & Species & Status & \multicolumn{2}{|c|}{ Residency } & Occurrance & \\
\hline Volunteer AAP & AMC & Mollusk & orange-footed pearly mussel & FE & & YR & Possible & $\mathrm{N}$ \\
\hline Redstone Arsenal & AMC & Mollusk & Orange-footed pearly mussel & $\mathrm{FE}$ & & YR & Possible & $\mathrm{N}$ \\
\hline Fort knox & TRADOC & Mollusk & Orange-footed pearly mussel & FE & & YR & Ext1rpated & HR \\
\hline Fort Campbel1 & FORSCOM & Mollusk & Orange-footed pearly mussel & EE & & YR & Possible & $\mathrm{NH}$ \\
\hline Fort Knox & TRADOC & Mollusk & Ortmann's pearly mussel & $\mathrm{C} 2$ & SE & YR & Possible & $\mathrm{R}$ \\
\hline Lexington/Bluegrass & AMC & B1rd & Osprey & SE & & M & Possible & $\mathrm{R}$ \\
\hline Savanna $\mathrm{AD}$ & AMC & Bird & Osprey & SE & & M & Possible & $\mathrm{N}$ \\
\hline Newport AAP & AMC & Bird & Osprey & SE & & M & Possible & $\mathrm{R}$ \\
\hline Fort Campbe 11 & EORSCOM & B1rd & Osprey & SE & & M & Possible & $\mathrm{N}$ \\
\hline Jollet AAP & AMC & Bird & Osprey & SE & & M & Possible & $\mathrm{N}$ \\
\hline Bager AAP & AMC & Bird & Osprey & SE & & M & Possible & R \\
\hline Camp Atterbury & NGB & Bird & Osprey & SE & & M & Possible & $R$ \\
\hline Fort knox & TRADOC & Bird & Osprey & SE & & M & Possible & $\mathrm{R}$ \\
\hline Volunteer AAP & AMC & B1rd & Osprey & SE & & B & Possible & $\mathrm{N}$ \\
\hline Indiana AAP & AMC & Bird & Osprey & SE & & $M$ & Possible & $\mathrm{R}$ \\
\hline Fort McCoy & FORSCOM & B1rd & Osprey & SE & & SR & Current & \\
\hline Camp Grayling & NGB & Bird & Osprey & ST & & B & Possible & $\mathrm{N}$ \\
\hline Fort Dix & TRADOC & Bird & Osprey & ST & . & B & Possible & $\mathrm{N}$ \\
\hline Seneca $A D$ & AMC & B1rd & Osprey & ST & & $M$ & Possible & $\ddot{R}$ \\
\hline P1catinny Arsenal & AMC & B1rd & Osprey & ST & & $M$ & Possible & $\ddot{R}$ \\
\hline Fort Drum & FORSCOM & Bird & Osprey & ST & & M & Possible & R \\
\hline U.S. Military Academy & Y USMA & B1rd & Osprey & ST & & M & Current & \\
\hline Fort Benning & TRADOC & Mollusk & Oval plgtoe & $\mathrm{C} 2$ & & YR & Possible & $\mathrm{N}$ \\
\hline Redstone Arsenal & AMC & Mollusk & Oyster mussel & $\mathrm{C} 2$ & & YR & unllkely & $\mathrm{NH}$ \\
\hline Bager AAP & AMC & Fish & Paddlef1sh & $3 \mathrm{C}$ & ST & YR & UnIlkely & $\mathrm{N}$ \\
\hline Redstone Arsenal & AMC & Moliusk & Pale lilliput pearly mussel & FE & & YR & Possible & $\mathrm{N}$ \\
\hline Volunteer AAP & AMC & Mollusk & Pale lilliput pearly mussel & FE & & YR & Possible & R \\
\hline Savanna $A D$ & AMC & Fish & Pallid shiner & $S E$ & & YR & Possible & $\mathrm{N}$ \\
\hline Camp Santiago & NGB & Bird & Peurto Rican plain plgeon & $\mathrm{FE}$ & & YR & Possible & $\mathrm{N}$ \\
\hline Plcatinny Arsenal & AMC & B1rd & Pled-billed grebe & SE & & M & Current & \\
\hline Lexington/Bluegrass & AMC & Bird & Pled-billed grebe & SE & & YR & Possible & $\mathrm{R}$ \\
\hline Fort Dix & TRADOC & Bird & Pled-billed grebe & SE & & YR & Possible. & $\mathrm{N}$ \\
\hline Jollet AAP & AMC & Bird & Pled-billed grebe & SE & & M & Possible & $\mathrm{N}$ \\
\hline Fort knox & TRADOC & Bird & Pled-b1lled grebe & SE & & W & Possible & $\mathrm{R}$ \\
\hline Fort Campbell & FORSCOM & Bird & Pled-billed grebe & SE & & YR. & Possible & $\mathrm{R}$ \\
\hline Fort Devens & FORSCOM & Bird & Pled-b1lled grebe & ST & & B & Possible & $\mathrm{N}$ \\
\hline Camp Edwards & NGB & Bird & Pled-bllled grebe & ST & & B & Possible & $\mathrm{R}$ \\
\hline Fort D1x & TRADOC & Amphiblan & Pine barrens tree frog & $3 \mathrm{C}$ & SE & YR & Possible & $\mathrm{N}$ \\
\hline Fort Campbell & FORSCOM & Mollusk & Plnk mucket pearly mussel & FE & & YR & Possible & NH \\
\hline Fort Knox & TRADOC & Mollusk & Pink mucket pearly mussel & EE & & YR & Possible & $\mathrm{NH}$ \\
\hline Volunteer AAP & AMC & Mollusk & Pink mucket pearly mussel & $\mathrm{FE}$ & & YR & Possible & $\mathrm{R}$ \\
\hline Indlana AAP & AMC & Mollusk & Pink mucket pearly mussel & FE & & YR & Possible & HR \\
\hline Redstone Arsenal & AMC & Mollusk & Pink mucket pearly mussel & FE & & YR & Possible & $\mathrm{N}$ \\
\hline Camp Atterbury & NGB & Mollusk & P1nk papershell mussel & SE & & YR & Possible & $\mathrm{N}$ \\
\hline Fort McCoy & FORSCOM & Blrd & Plping plover & $E E$ & & M & Possible & $\mathrm{N}$ \\
\hline Bager AAP & AMC & Blrd & Plping plover & $\mathrm{FE}$ & & M & Possible & $\mathrm{N}$ \\
\hline Redstone Arsenal & AMC & B1rd & Piping plover & FT & & M & Possible & $\mathrm{R}$ \\
\hline Fort Campbell & EORSCOM & B1rd & Plping plover & FT & & $\mathrm{T}$ & Possible & $\mathrm{R}$ \\
\hline Fort Knox & TRADOC & B1rd & Plping plover & FT & & B & Possible & $\mathrm{N}$ \\
\hline Fort $\mathrm{D} 1 \mathrm{x}$ & TRADOC & B1rd & Plping plover & FT & & $\mathrm{T}$ & Possible & $\mathrm{N}$ \\
\hline Camp Edwards & NGB & Bird & Piping plover & FT & & B & Possible & $\mathrm{N}$ \\
\hline Camp Sant1ago & NGB & Bird & Piping plover & ET & & $\mathrm{T}$ & Current & \\
\hline Fort Eustis & TRADOC & Bird & Piplng plover & FT & & $\mathrm{T}$ & Possible & $\mathrm{N}$ \\
\hline Fort stewart & FORSCOM & Bird & P1ping plover & ET & & W & Possible & $\mathrm{N}$ \\
\hline Fort Story & TRADOC & B1rd & Plping plover & ET & & $\mathrm{T}$ & Possible & $\mathrm{R}$ \\
\hline Sunny Polnt MT & MTMC & Bird & P1ping plover & FT & & W & Possible & $\mathrm{N}$. \\
\hline Camp Santlago & NGB & Reptile & Puerto Rican boa & $\mathrm{FE}$ & & YR & Current & \\
\hline Camp Santiago & NGB & Rept1le & Puerto Rlcan crested toad & ET & & YR & Possible & $\mathrm{NH}$, \\
\hline Fort story & TRADOC & Mamma 1 & Pungo mouse & $\mathrm{C} 2$ & & YR & Possible & $\mathrm{N}$ \\
\hline Fort Campbell & FORSCOM & Mollusk & Purple catspaw pearly mussel & $\mathrm{PE}$ & & $\mathrm{YR}$ & Possible & $\mathrm{NH}$ \\
\hline Fort Knox & TRADOC & Mollusk & Purple 11111put & $\mathrm{C} 2$ & SE & YR & Possible & NH \\
\hline Fort McClellan & TRADOC & Mollusk & Purple lilliput & $\mathrm{C} 2$ & & $\mathrm{YR}$ & Possible & $\mathrm{NH}$ \\
\hline Fort McClellan & TRADOC & Fish & Pygmy sculpin & FT & & YR & Possible & $\mathrm{N}$ \\
\hline Anniston $\mathrm{AD}$ & $\mathrm{AMC}$ & Fish & Pygmy sculpin & FT & & YR & Possible & $\mathrm{N}$ \\
\hline Milan AAP & AMC & Mamma 1 & Rafinesque's blg-eared bat & $\mathrm{C} 2$ & & YR & Possible & $\mathrm{N}$ \\
\hline Fort Campbel1 & FORSCOM & Mamma 1 & Rafinesque's big-eared bat & $\mathrm{C} 2$ & ST & YR & Possible & R \\
\hline Fort Jackson & TRADOC & Mamma 1 & Rafinesque's big-eared bat & $\mathrm{C} 2$ & & YR & Possible & $\mathrm{R}$ \\
\hline Fort Knox & TRADOC & Mammal & Rafinesque's big-eared bat & $\mathrm{C} 2$ & ST & YR & Possible & $\ddot{R}$ \\
\hline Sunny Point MT & MTMC & Mamma 1 & Rafinesque's big-eared bat & $\mathrm{C} 2$ & & YR & Possible & R \\
\hline Lexington/Bluegrass & AMC & Mamma l & Rafinesque's big-eared bat. & $\mathrm{C} 2$ & ST & $\mathrm{F}, \mathrm{M}$ & Possible & $\mathrm{N}$ \\
\hline Savanna $A D$ & AMC & Mollusk & Ralnbow & SE & & YR & Possible & $\mathrm{N}$ \\
\hline Joliet AAP & AMC & Mollusk & Ralnbow & SE & & YR & Possible & $\mathrm{N}$ \\
\hline Mississippi AAP & AMC & Reptile & Ralnbow snake & SE & & YR & Possible & $\mathrm{R}$ \\
\hline Sunny Point MT & MTMC & Mollusk & Rare skipper & $\mathrm{C} 2$ & & & Current & \\
\hline Anniston $A D$ & AMC & Mammal & Red wolf & $\mathrm{FE}$ & & YR & Ext1rpated & HR \\
\hline Sunny Point MT & MTMC & Mammal & Red wolf & EE & & YR & Extirpated & $\mathrm{HR}$ \\
\hline Volunteer AAP & $\mathrm{AMC}$ & Mammal & Red wolf & $\mathrm{FE}$ & & $\mathrm{YR}$ & Extirpated & HR \\
\hline Fort McClellan & TRADOC & Mammal & Red wolf & $\mathrm{FE}$ & & YR & Extirpated & HR \\
\hline Fort stewart & FORSCOM & Mammal & Red wolf & $\mathrm{FE}$ & & YR & Extirpated & $\mathrm{HR}$ \\
\hline Fort Bragg & FORSCOM & Mammal & Red wolf & $\mathrm{FE}$ & & YR & Extirpated & $\mathrm{HR}$ \\
\hline Fort Gordon & TRADOC & Mammal & Red wolf & $\mathrm{FE}$ & & YR & Ext1rpated & HR \\
\hline Miss1ss1ppi AAP & AMC & Mamma 1 & Red wolf & $\mathrm{FE}$ & & YR & Extirpated & HR \\
\hline Fort Rucker & TRADOC & Mammal. & Red wolf & $\mathrm{FE}$ & & YR & Ext1rpated & $\mathrm{HR}$ \\
\hline Camp shelby & NGB & Mammal & Red wolf & $\mathrm{EE}$ & & YR & Ext1rpated & HR \\
\hline Milan AAP & AMC & Mamma 1 & Red wolf & $\mathrm{FE}$ & & YR & Extirpated & HR \\
\hline Fort Campbel1 & FORSCOM & Mammal & Red wolf & FE & & YR & Extirpated & HR \\
\hline
\end{tabular}


Appendix B (continued)

\begin{tabular}{|c|c|c|c|c|c|c|c|}
\hline Installation & IACOM & Taxon & Species & Status & Residency & \multicolumn{2}{|c|}{ Occurrance } \\
\hline Camp Blanding & NGB & Mamma 1 & Red wolf & $\mathrm{FE}$ & YR & Ext1rpated & HR \\
\hline Lexington/Bluegrass & AMC & Mamma I & Red wolf & EE & YR & Extirpated & HR \\
\hline Fort Jackson & TRADOC & Mamma 1 & Red wolf & FE & YR & Ext1rpated & HR \\
\hline Eort Knox & TRADOC & Mamma I & Red wolf & FE & YR & Extirpated & $\mathrm{HR}$ \\
\hline Fort Benning & TRADOC & Mamma 1 & Red wolf & FE & YR & Ext1rpated & HR \\
\hline Redstone Arsenal & AMC & Mamma 1 & Red wolf & FE & YR & Ext1rpated & HR \\
\hline Bager AAP & AMC & Fish & Redfin shiner & ST & YR & Unllkely & $\mathrm{N}$ \\
\hline Fort McCoy & FORSCOM & Fish & Redf In shiner & ST & YR & Possible & $\mathrm{N}$ \\
\hline Letterkenny $\mathrm{AD}$ & AMC & Rept 1le & Red-bellied turtle & SE & YR & Possible & $\mathrm{N}$ \\
\hline Fort Bragg & EORSCOM & B1rd & Red-cockaded woodpecker & $\mathrm{FE}$ & YR & Current & \\
\hline Milan AAP & AMC & Bird & Red-cockaded woodpecker & FE & YR & Ext1rpated & HR \\
\hline Fort stewart & FORSCOM & B1rd & Red-cockaded woodpecker & FE & YR & Current & \\
\hline Sunny Point MT & MTMC & Bird & Red-cockaded woodpecker & FE & YR & Current & \\
\hline Fort Mcclellan & TRADOC & BIrd & Red-cockaded woodpecker & FE & YR & Possible & $\mathrm{N}$ \\
\hline Fort Bennlng & TRADOC & B1rd & Red-cockaded woodpecker & FE & YR & Current & \\
\hline Fort Gordon & TRADOC & B1rd & Red-cockaded woodpecker & EE & YR & Current & \\
\hline Fort Jackson & TRADOC & B1rd & Red-cockaded woodpecker & FE & YR & Current & \\
\hline Mississipp1 AAP & AMC & B1rd & Red-cockaded woodpecker & FE & YR & Possible & $\mathrm{R}$ \\
\hline Camp Shelby & NGB & B1rd & Red-cockaded woodpecker & FE & YR & Current & \\
\hline Volunteer AAP & AMC & B1rd & Red-cockaded woodpecker & FE & YR & Possible & NH \\
\hline Camp Blanding & NGB & B1rd & Red-cockaded woodpecker & $\mathrm{FE}$ & YR & Current & \\
\hline Anniston $A D$ & AMC & Blrd & Red-cockaded woodpecker & $\mathrm{FE}$ & YR & Possible & $\mathrm{N}$ \\
\hline Fort Rucker & TRADOC & Blrd & Red-cockaded woodpecker & $\mathrm{FE}$ & YR & Unlikely & $\mathrm{R}$ \\
\hline P1catinny Arsenal & AMC & B1rd & Red-headed woodpecker & ST & YR & Possible & $\mathbf{R}$ \\
\hline Fort Dix & TRADOC & B1rd & Red-headed woodpecker & ST & YR & Possible & $\mathrm{N}$ \\
\hline Fort McCoy & FORSCOM & B1rd & Red-necked grebe & SE & M & Possible & $\mathbf{R}$ \\
\hline Jollet AAP & AMC & B1rd & Red-shouldered hawk & SE & B & Possible & R \\
\hline Savanna $A D$ & AMC & Bird & Red-shouldered hawk & SE & B & Current & \\
\hline Camp Grayling & NGB & B1rd & Red-shouldered hawk & ST & B & Possible & $\mathrm{N}$ \\
\hline Seneca $A D$ & AMC & B1rd & Red-shouldered hawk & ST & M & Possible & R \\
\hline Fort D1 $x$ & TRADOC & B1rd & Red-shouldered hawk & ST & W & Possible & $\mathrm{N}$ \\
\hline Bager AAP & AMC & B1rd & Red-shouldered hawk & ST & B & Possible. & $\mathrm{N}$ \\
\hline Fort McCoy & FORSCOM & B1rd & Red-shouldered hawk & ST & B & Possible & $\mathrm{N}$ \\
\hline Plcatinny Arsenal & AMC & B1rd & Red-shouldered hawk & ST & $\mathrm{T}$ & Current & \\
\hline Fort Drum & FORSCOM & Blrd & Red-shouldered hawk & ST & B & Possible & $\mathrm{R}$ \\
\hline U.S. M111tary Academy & Y USMA & B1rd & Red-shouldered hawk & ST & B & Possible & $\mathrm{N}$ \\
\hline Fort knox & TRADOC & Mollusk & Ring pink & FE & YR & Possible & $\mathrm{NH}$ \\
\hline Redstone Arsenal & AMC & Mollusk & Ring pink & PE & YR & Possible & $\mathrm{R}$ \\
\hline M1ss1ssipp1 AAP & AMC & Reptile & Ringed sawback turtle & ET & YR & Possible & $\mathrm{R}$ \\
\hline Milan AAP & AMC & Mamma 1 & River otter & ST & YR & Unlikely & $\mathrm{N}$ \\
\hline Fort Campbell & FORSCOM & Mamma 1 & River otter & ST & YR & Possible & $\mathrm{R}$ \\
\hline Savanna $A D$ & AMC & Mamma 1 & River otter & ST & YR & Current & \\
\hline Jollet AAP & AMC & Marmma 1 & River otter & ST & YR & Possible & $\mathrm{R}$ \\
\hline Eort McCoy & FORSCOM & F1sh & R1ver redhorse & ST & YR & Possible & $\mathrm{N}$ \\
\hline Jollet AAP & AMC & Fish & R1ver redhorse & ST & YR & Possible & $\mathrm{N}$ \\
\hline Bager AAP & AMC & Mollusk & Rock pocketbook & ST & YR & Possible & $\mathrm{N}$ \\
\hline Sunny Polnt MT & MTMC & B1rd & Roseate tern & FE & M & Possible & $\mathrm{R}$ \\
\hline Camp Edwards & NGB & B1rd & Roseate tern & FE & F, M & Possible & $\mathrm{R}$ \\
\hline Camp Santiago & NGB & B1rd & Roseate tern & FT & B & Possible & $\mathrm{N}$ \\
\hline Volunteer AAP & AMC & Mollusk & Rough pigtoe & FE & YR & Unlikely & NH \\
\hline Fort Knox & TRADOC & Mollusk & Rough plgtoe & $\mathrm{FE}$ & YR & Extirpated & HR \\
\hline Indlana AAP & AMC & Mollusk & Rough plgtoe & FE & YR & Extirpated & HR \\
\hline Fort Campbel1 & FORSCOM & Mollusk & Rough pigtoe & FE & YR & Possible & NH \\
\hline Redstone Arsenal & AMC & Mollusk & Rough pigtoe & $\mathrm{FE}$ & YR & Possible & $\mathrm{N}$ \\
\hline Newport AAP & AMC & Mollusk & Rough pigtoe & FE & YR & Possible & NH \\
\hline Indiana AAP & $\mathrm{AMC}$ & Mollusk & Rough rabbit's foot & C2 & YR & Extirpated & HR \\
\hline Fort knox & TRADOC & Mollusk & Rough rabblt's foot & $\mathrm{C2}$ & YR & Extirpated & $\mathrm{HR}$ \\
\hline Fort Campbell & FORSCOM & Mollusk & Rugged rlver snall & $\mathrm{C2}$ & YR & Possible & $\mathrm{NH}$ \\
\hline Bager AAP & AMC & Mollusk & Salamander mussel & $\mathrm{C} 2$ & YR & Possible & $\mathrm{N}$ \\
\hline Fort knox & TRADOC & Mollusk & Salamander mussel & C2 & ST & Possible & $\mathrm{N}$ \\
\hline Jollet AAP & AMC & Mollusk & Salamander mussel & $\mathrm{C} 2$ & YR & Possible & $\mathrm{N}$ \\
\hline Jollet AAP & AMC & B1rd & Sandh111 crane & SE & M & Possible & $\mathrm{N}$ \\
\hline Volunteer AAP & AMC & B1rd & Sandh111 crane & ST & $\mathrm{T}$ & Possible & N \\
\hline Fort Bragg & FORSCOM & Fish & Sandhills chub & $\mathrm{C} 2$ & YR & Possible & $\mathrm{N}$ \\
\hline Picatinny Arsenal & AMC & Blrd & Savannah sparrow & ST & M & Current & \\
\hline Fort D1x & TRADOC & B1rd & Savannah sparrow & ST & YR & Possible & $\mathrm{N}$ \\
\hline Savanna $A D$ & AMC & Mollusk & Scaleshell & C2 & YR & Possible & NH \\
\hline Fort Mcclelian & TRADOC & Mollusk & Sculpin snall & C2 2 & YR & Possible & $\mathrm{N}$ \\
\hline Anniston $A D$ & AMC & Mollusk & Sculpin snail & $\mathrm{C2}$ & YR & Posslble & $\mathrm{N}$ \\
\hline Fort story & TRADOC & B1rd & Sedge wren & RSE & w & Possible & $\mathbf{R}$ \\
\hline Fort Eustis & TRADOC & B1rd & Sedge wren & RSE & $w$ & Possible & $\mathbf{R}$ \\
\hline Fort D1x & TRADOC & B1rd & Sedge wren & SE & B & Possible & $\mathbf{R}$ \\
\hline Plcatinny Arsenal & AMC & B1rd & Sedge wren & SE & B & Possible & $\mathrm{N}$ \\
\hline Camp Atterbury & NGB & B1rd & Sedge wren & ST & B & Possible & R \\
\hline Newport AAP & AMC & B1rd & Sedge wren & ST & B & Possible. & $\mathbf{R}$ \\
\hline Fort Campbel1 & FORSCOM & Blrd & Sharp-shinned hawk & SE & YR & Possible & $\mathrm{N}$ \\
\hline Savanna $A D$ & AMC & Bird & Sharp-shinned hawk & SE & YR & Possible & $\mathrm{N}$ \\
\hline Sollet AAP & AMC & B1rd & Sharp-shinned hawk & SE & YR & Possible & $\mathrm{R}$ \\
\hline Volunteer AAP & AMC & Bird & Sharp-shinned hawk & ST & YR & Possible & $\mathrm{N}$ \\
\hline Milan AAP & AMC & B1rd & Sharp-shlnned hawk & ST & YR & Possible & $\mathrm{N}$ \\
\hline Newport AAP & AMC & Mollusk & Sheepnose & SE & YR & Possible & $\mathrm{N}$ \\
\hline Jollet AAP & AMC & Mollusk & Sheepnose & ST & YR & Possible & $\mathrm{N}$ \\
\hline Savanna $A D$ & AMC & Mollusk & Sheepnose & ST & YR & Possible & NH \\
\hline Camp Blanding & NGB & Mammal & Sherman's fox squirrel & $\mathrm{C} 2$ & YR & Current & \\
\hline Fort stewart & FORSCOM & Mamma 1 & Sherman's pocket gopher & $3 A$ & YR & Possible & HR \\
\hline Redstone Arsenal & AMC $\quad$ D & Mollusk & Shiny plgtoe & $\mathrm{FE}$ & YR & Possible & $\mathrm{N}$ \\
\hline
\end{tabular}




\section{Appendix B (continued)}

\begin{tabular}{|c|c|c|c|c|c|c|c|c|}
\hline Installation & MACOM & Taxon & Species & tatus & Res & sidency & Occurrance & \\
\hline Fort Benning & TRADOC & Mollusk & Shiny-rayed pocketbook & C2 & & $Y R$ & Possible & $\mathrm{N}$ \\
\hline U.S. M111tary Academy & USMA & Fish & Shortnose sturgeon & $\mathrm{FE}$ & & Adjacent & Possible & $\mathrm{R}$ \\
\hline Fort Stewart & FORSCOM & Elsh & Shortnose sturgeon & FE & & $Y R$ & Possible & $\mathrm{N}$ \\
\hline Camp Edwards & NGB & Fish & Shortnose sturgeon & $\mathrm{FE}$ & & Adjacent & Possible & $\mathrm{R}$ \\
\hline Fort story & TRADOC & Fish & Shortnose sturgeon & FE & & YR & Possible & $\mathrm{R}$ \\
\hline Sunny Point MT & MTMC & Fish & Shortnose sturgeon & FE & & YR & Possible & $\mathrm{N}$ \\
\hline Aberdeen PG & AMC & Fish & Shortnose sturgeon & FE & & YR & Possible & $\mathrm{R}$ \\
\hline Camp Edwards & NGB & Blrd & Short-eared ow 1 & SE & & B & Possible & $\mathrm{N}$ \\
\hline Camp Grayling & NGB & B1rd & Short-eared owl & SE & & B & Possible & R \\
\hline Savanna $A D$ & AMC & Bird & Short-eared owl & SE & & YR & Possible & $\mathrm{N}$ \\
\hline Jollet AAP & AMC & Blrd & Short-eared ow 1 & SE & & YR & Posslble & $\mathrm{N}$ \\
\hline Plcatinny Arsenal & AMC & B1rd & Short-eared owl & SE & & W & Possible & $\mathrm{R}$ \\
\hline Fort $D 1 x$ & TRADOC & B1rd & Short-eared ow 1 & SE & & YR & Possible & $\mathrm{R}$ \\
\hline Bager AAP & AMC & Insect & Silphlum borer moth & SE & & & Possible & $\mathrm{N}$ \\
\hline Redstone Arsenal & AMC & Mollusk & Slabslde pearly mussel & $\mathrm{C} 2$ & & YR & Possible & $\mathrm{N}$ \\
\hline Redstone Arsenal & AMC & Fish & Slackwater darter & FE & & YR & Possible & $\mathrm{N}$ \\
\hline Fort Campbell & FORSCOM & Fish & slender madtom & SE & & YR & Possible & $\mathrm{N}$ \\
\hline Joliet AAP & AMC & Mollusk & Slippershell mussel & SE & & YR & Possible & $\mathrm{N}$ \\
\hline Fort Campbell & FORSCOM & Fish & Smaliscale darter & $S E$ & & YR & Possible & $\mathrm{N}$ \\
\hline Volunteer AAP & AMC & Fish & Sna1l darter & FT. & & YR & Possible & $\mathrm{N}$ \\
\hline Jollet AAP & AMC & B1rd & Snowy egret & SE & & PB & Possible & $\mathrm{N}$ \\
\hline Jollet AAP & AMC & Mollusk & Snuff box & SE & & YR & Possible & $\mathrm{N}$ \\
\hline Newport AAP & AMC & Mollusk & Snuff box & SE & & YR & Possible & $\mathrm{N}$ \\
\hline Savanna $A D$ & AMC & Mollusk & Snuff box & SE & & YR & Possible & $\mathrm{N}$ \\
\hline Camp Blanding & NGB & B1rd & Southeastern American kestrel & $\mathrm{C} 2$ & ST & YR & Current & \\
\hline Fort Campbeli & FORSCOM & Mammal & Southeastern bat & $\mathrm{C} 2$ & & E & Possible & R \\
\hline Fort Knox & TRADOC & Mammal & Southeastern bat & $\mathrm{C} 2$ & SE & $\mathrm{E}$ & Possible & R \\
\hline Fort Rucker & TRADOC & Mollusk & Southern kldneyshell & $\mathrm{C} 2$ & & YR & Possible & HR \\
\hline Fort Belvolr & MDW & Mamma 1 & Southern pygmy shrew & $\mathrm{C} 2$ & & YR & Possible & $\mathrm{HR}$ \\
\hline Lexington/Bluegrass & AMC & Mamma 1 & Southern pygmy shrew & $\mathrm{C} 2$ & & YR & Possible & $\mathrm{N}$ \\
\hline Fort George Meade & FORSCOM & Mamma 1 & Southern pygmy shrew & $\mathrm{C} 2$ & & YR & Possible & R \\
\hline Fort Campbell & FORSCOM & Mamma 1 & Southern pygmy shrew & $\mathrm{C} 2$ & & YR & Possible & $\mathrm{R}$ \\
\hline Fort knox & TRADOC & Mamma 1 & Southern pygmy shrew & $\mathrm{C} 2$ & & YR & Possible & $\mathrm{N}$ \\
\hline Fort Rucker & TRADOC & Mollusk & Southern sandshell & $\mathrm{C} 2$ & & YR & Possible & $\mathrm{HR}$ \\
\hline Bager AAP & AMC & Fish & Speckled chub & ST & & YR & Possible & N \\
\hline Jollet AAP & AMC & Mollusk & Spectaclecase & $\mathrm{C} 2$ & SE & YR & Possible & $\mathrm{N}$ \\
\hline Savanna $A D$ & AMC & Mollusk & spectaclecase & $\mathrm{C} 2$ & SE & YR & Possible & NH \\
\hline Volunteer AAP & AMC & Mollusk & Splny river sna1l & $\mathrm{C} 1$ & SE & YR & Unlikely & NH \\
\hline Fort knox & TRADOC & Bird & Spotted Sandpiper & SE & & B & Posslble & $\mathrm{R}$ \\
\hline Fort Campbel1 & FORSCOM & Bird & Spotted sandplper & SE & & YR & Possible & $\mathrm{N}$ \\
\hline Jollet AAP & AMC & Rept1le & Spotted turtle & SE & & YR & Possible & $\mathrm{N}$ \\
\hline Eort Indlantown Gap & FORSCOM & Insect & Sugar maple longhorn beetle & $\mathrm{C} 2$ & ST & & Possible & $\mathrm{N}$ \\
\hline Jollet AAP & AMC & B1rd & Swainson's hawk & $3 \mathrm{C}$ & SE & M & Possible & $\mathrm{R}$ \\
\hline Savanna $\mathrm{AD}$ & AMC & Bird & Swa1nson's hawk & $3 c$ & SE & M & Possible & $\mathrm{R}$ \\
\hline Redstone Arsenal & AMC & Mollusk & Tan riffleshell & EE & & YR & Possible & $\mathrm{NH}$ \\
\hline Fort Campbell & FORSCOM & Mollusk & Tan riffleshell & $\mathrm{FE}$ & & YR & Unllkely & $\mathrm{NH}$ \\
\hline Fort Indlantown Gap & FORSCOM & Insect & Tawny crescent & $\mathrm{C} 2$ & ST & & Possible & $\mathrm{N}$ \\
\hline Volunteer AAP & AMC & Amphibian & Tennessee cave salamander & $\mathrm{C} 2$ & ST & YR & Possible & $\mathrm{N}$ \\
\hline Redstone Arsenal & AMC & Mollusk & Tennessee clubshell & $\mathrm{C} 2$ & & YR & Unl1kely & NH \\
\hline Fort Mcclellan & TRADOC & Mollusk & Tennessee heelsplitter & $\mathrm{C} 2$ & & YR & Possible & NH \\
\hline Plcatinny Arsenal & AMC & Reptile & Timber rattlesnake & SE & & YR & Current & \\
\hline Fort Dix & TRADOC & Reptile & Timber rattlesnake & SE & & YR & Possible & N \\
\hline U.S. Military Academy & USMA & Reptile & Timber rattlesnake & ST & & YR & Current & \\
\hline Seneca $A D$ & AMC & Rept1le & Timber rattlesnake & ST & & YR & Possible & $\mathrm{R}$ \\
\hline P1catinny Arsenal & AMC & Amphiblan & Trembley's salamander & SE & & YR & Possible & N \\
\hline Indiana AAP & AMC & Mollusk & Tuberculed-blossom pearly mussel & $\mathrm{FE}$ & & YR & Ext1rpated & HR \\
\hline Volunteer AAP & AMC & Mollusk & Tuberculed-blossom pearly mussel & $\mathrm{FE}$ & & YR & Extirpated & \\
\hline Redstone Arsenal & AMC & Fish & Tuscombla darter & $\mathrm{C} 2$ & & YR & Possible & $\mathrm{N}$ \\
\hline Fort Mcclellan & TRADOC & Mollusk & Upland combshell & C2 & & YR & Possible & $\mathrm{NH}$ \\
\hline Anniston $\mathrm{AD}$ & AMC & Mollusk & Upland combshell & $\mathrm{C} 2$ & & YR & Possible & NH \\
\hline Fort Devens & FORSCOM & Blrd & Upland sandplper & SE & & B & Current & \\
\hline Fort Knox & TRADOC & Bird & Upland sandp1per & SE & & $M$ & Possible & $\mathrm{R}$ \\
\hline Plcatinny Arsenal & AMC & Bird & Upland sandplper & $S E$ & & $\mathrm{~B}$ & Current & \\
\hline Fort Campbell & FORSCOM & B1rd & Upland sandpiper & SE & & $\mathrm{T}$ & Possible & R \\
\hline Camp Edwards & NGB & B1rd & Upland sandplper & SE & & B & Current & \\
\hline Camp Atterbury & NGB & Blrd & Upland sandplper & SE & & B & Possible & $\mathrm{R}$ \\
\hline Lexington/Bluegrass & AMC & B1rd & Upland sandp1per & SE & & $M$ & Possible & R \\
\hline Joliet AAP & AMC & B1rd & Upland sandplper & SE & & B & Current & \\
\hline Fort D1X & TRADOC & B1rd & Upland sandplper & $\mathrm{SE}$ & & B & Possible & $\mathrm{N}$ \\
\hline Savanna $A D$ & AMC & B1rd & Upland sandplper & SE & & B & Current & \\
\hline Fort Indiantown Gap & FORSCOM & B1rd & Upland sandplper & ST & & B & Possible & $\mathrm{N}$ \\
\hline Letterkenny $\mathrm{AD}$ & AMC & B1rd & Upland sandplper & ST & & B & Possible & $\mathrm{N}$ \\
\hline Savanna $A D$ & AMC & B1rd & Veery & ST & & M & Possible & $\mathrm{R}$ \\
\hline Jollet AAP & AMC & Bird & Veery & ST & & B & Likely & $\mathrm{N}$ \\
\hline Volunteer AAP & AMC & Mollusk & Verrucose flle snall & $\mathrm{C} 2$ & SE & YR & Possible & $\mathrm{N}$ \\
\hline Fort D.1x & TRADOC & B1rd & Vesper sparrow & SE & & YR & Possible & $\mathrm{N}$ \\
\hline Plcatinny Arsenal & AMC & B1rd & Vesper sparrow & SE & & M & Current & \\
\hline Radford AAP & AMC & Mollusk & V1rgina fringed mautain snall & FE & & YR & Possible & $\mathrm{N}$ \\
\hline Lexington/Bluegrass & AMC & Mammal & V1rginia big-eared bat & $\mathrm{FE}$ & & $\mathrm{F}, \mathrm{M}$ & Possible & $\mathrm{N}$ \\
\hline Volunteer AAP & AMC & B1rd & Virginia rail & SE & & YR & Possible & R \\
\hline Milan AAP & AMC & B1rd & V1rginia rall & SE & & $\mathrm{T}$ & Possible & $\mathrm{N}$ \\
\hline Fort Campbel1 & FORSCOM & Bird & V1rginia ra11 & SE & & M & Possible & $\mathrm{R}$ \\
\hline Fort stewart & FORSCOM & Mamma 1 & West Indian manatee & FE & & Adfacent & Possible & $\mathrm{R}$ \\
\hline Sunny Point MT & MTMC & Mammal & West Indian manatee & $\mathrm{FE}$ & & Adjacent & Possible & $\mathrm{R}$ \\
\hline Bager AAP & AMC & Reptile & Western box turtle & SE & & YR & Possible & $\mathrm{N}$ \\
\hline Fort Campbe 11 & FORSCOM & Reptile & Western pygmy rattlesnake & ST & & YR & Possible & R \\
\hline
\end{tabular}




\section{Appendix B (continued)}

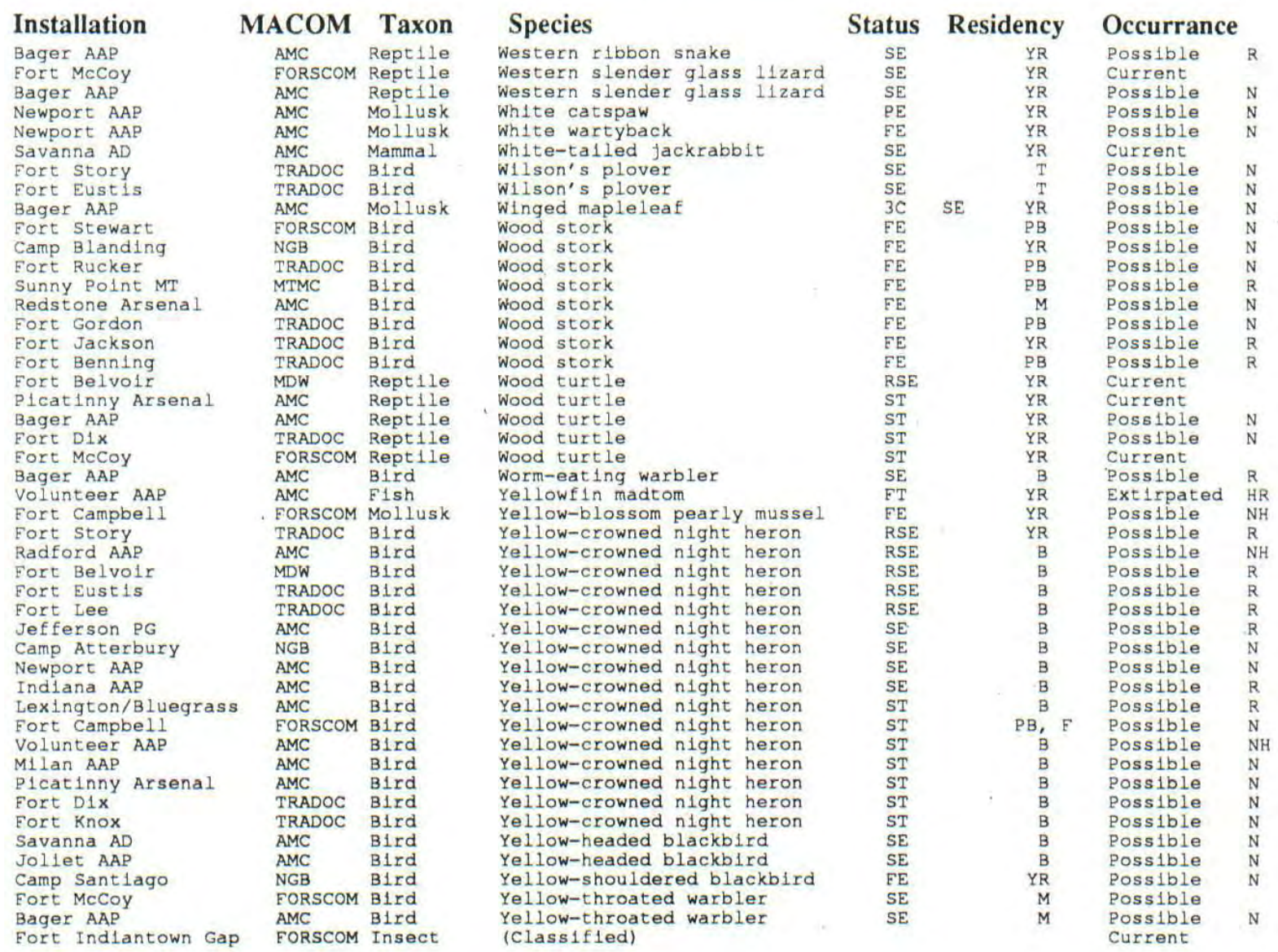

Status

3A ; 3C ; C1 - Category 1; C2 - Category 2; FE - Federally endangered FT - Federally threatened; FTSA - FT due to similarity of appearance; PE - proposed endangered; SE - State endangered; ST - State threatened.

Residency

Adfacent - adjacent areas (may be affected); B - Breeding season; F - Forag1ng; M - Migration; PB - Post breeding; T - Transient; W - Winter season; YR - Year round.

Occurrance

Current - Known to occur on the Installation presently or within very recent past; Ext1rpated - Species presently ext1rpated in the reglon but otherwise might have occurred; Likely - Likely to occur; Possible - May occur; Unlikely - Possible but unlikely to occur.

HR- Historic range; specles historlc range includes the installation; $N$ - Nearby; species known to occur in the vicinity or within surrounding counties; NH - Nearby, HIstorlc; historlcally known to occur as above; R - Range; species current range includes the installation. 


\section{APPENDIX C: A STANDARD STATUS REPORT FORMAT FOR THREATENED AND ENDANGERED ANIMAL SPECIES ON ARMY LANDS}

\section{INTRODUCTION}

The Endangered Species Act requires federal agencies to carry out programs for the conservation of listed species and to ensure that actions authorized, funded, or carried out by such agencies do not jeopardize the continued existence of listed species. Compliance with the Act and Army policy described in Army Regulation (AR) 420-74, requires availability of current and updatable information on the distribution and status of threatened and endangered species on Army lands.

A standardized status report format for threatened and endangered plant species has been proposed and is recommended for use by the U.S. Fish and Wildlife Service. Recently, this format was used to report on the status of Haplopappus fremontii subsp. monocephalus, a Category 2 candidate species, on the U.S. Army Pinon Canyon Maneuver Site, Colorado. As shown on the following pages, the format is also adaptable to wildlife.

The advantage to the use of this format is that the report is very detailed with respect to taxonomy, reproduction biology, ecology, and the distribution of historical and present populations. Such information can be used to evaluate the potential impacts on individual species of both military and nonmilitary uses of Army lands, and to help identify information gaps and data needs. It also allows Army natural resource managers the opportunity to recommend status changes and management alternatives applicable to their installations. Eventual Army-wide compilation of status reports for all listed species occurring on Army lands will provide a mechanism for keeping both major command and Department of the Army natural resource management planners and policymakers well informed about the distribution and status of threatened and endangered species on Army lands. 
STATUS REPORT ON POPULATIONS OF THE BLACK-CAPPED VIREO ON U.S. ARMY LANDS

Taxon name: Vireo atricapillus Woodhouse

Common Name: Black-capped Vireo

Family: Vireonidae

States/Nations where taxon occurs: Texas and Oklahoma, USA; Mexico

Current federal status: Endangered

Author of report: David J. Tazik

Original date of report: May 1991

Date of most recent revision: none

Individual to whom further information and comments should be sent: David J: Tazik, U.S. Army Construction Engineering Research Laboratory P.O. Box 9005, Champaign, IL 61826-9005 


\section{STATUS REPORT ON POPULATIONS OF THE BLACK-CAPPED VIREO ON U.S. ARMY}

LANDS

\section{SPECIES INFORMATION}

1. Classification and nomenclature

A. Species

\section{Scientific Name}

a. Binomial--Vireo atricapillus Woodhouse

b. Full bibliographic citation--Woodhouse, Samual W. 1852. Descriptions of new species of the genus Vireo, Vieill., and Zonotrichia, Swains. Proceedings of the Academy of Natural Sciences of Philadelphia 6:60.

c. Type specimen(s)--San Pedro River, 10 miles from source=Devil's River, near Sonora, Sutton County, Texas (Deignan 1961). Collected 26 May 1851 by S.W. Woodhouse. Deposited in Museum of Natural History, Division of Birds (USNM), number 15040.

2. Pertinent synonym--Vireo atricapilla Woodhouse

3. Common names--Black-capped Vireo

4. Taxon codes--VIAT (USACERL); American Ornithologist's Union (AOU) No. 630.

5. Size of genus--25 species for North America (American Omithologist's Union 1983).

\section{B. Family classification}

1. Family name--Vireonidae

2. Subfamily--Vireoninae

\section{Pertinent family synonym--None}

\section{Common name for family--Vireo Family}

C. Major animal group--Aves; passerine; songbird.

D. History of knowledge of taxon--(Marshal et al. 1985). The name of the Black-capped Vireo has remained unchanged since the original description by Woodhouse. However, the area of the type locality has changed and is now unsuitable. Bunker (1910) studied nesting, stomach contents, and plumages of a dense population in Blaine County, Oklahoma. He discovered the sexual dimorphism in color, unique in the vireo family. At that time, the U.S. breeding range included Kansas, Oklahoma, and Texas. The species disappeared from Kansas after 1953 (Tordoff 1956). Graber $(1957,1961)$ studied in detail the distribution, ecology, and population biology of the species in Oklahoma and Texas. J.A. Grzybowski presently is studying population and nesting ecology in parts of Oklahoma and Texas. 
E. Comments on current alternative taxonomic treatments-- (Marshal et al. 1985). There is a close similarity between $V$. atricapillus and its Mexican neighbor to the south, V. nelsoni, the Dwarf Vireo. Common traits of brick red iris, blackish tertials, and secondary wing coverts of adults, pure white eggs, and exceptionally complex musical song distinguish these two species from other members of the genus. $V$. nelsoni is similar in appearance to the female $V$. atricapillus, except that the former is darker, has a more olive green cap and duller body, and more cream-colored, less bright wing bars. Although each occupy similar habitat, they have not been seen together. V. nelsoni is known to occur from Jalisco and Guanajuato to Oxaca. Presently, there is no evidence to justify a merger of these two taxa.

2. Present legal or other formal status

\section{A. International}

1. Present designation or proposed protection or regulation--None.

2. Other current formal status recommendations--None.

3. Review of past status--Not applicable.

\section{B. National}

\section{United States}

a. Present designation or proposed legal protection or regulation--USDI: Listed as endangered effective 5 November 1987 (52 FR 37420- 37423 [6 October 1987]).

b. Other current formal status recommendations--None.

c. Review of past status--USDI: Designated a Category 2 candidate for listing in 1982 (47 FR 58454 [30 December 1982]); and as Category 1 in 1985 (50 FR 37958 [18 September 1985]).

C. State or equivalent

\section{Kansas}

a. Present designated or proposed legal protection or regulation--Department of Wildlife and Parks: None.

b. Other current formal status recommendations--Unknown.

c. Review of past status--May have been listed previously; unknown at this time.

\section{Oklahoma}

a. Present designated or proposed legal protection or regulation--Oklahoma Department of Wildlife Conservation: Endangered.

b. Other current formal status recommendations--Unknown.

c. Review of past status--Added to state list during 1987. 


\section{Texas}

a. Present designated or proposed legal protection or regulation--Texas Parks and Wildlifé: Endangered.

b. Other current formal status recommendations--Texas Organization for Endangered Species: Endangered.

c. Review of past status--Listed by state of Texas as threatened on 1 March 1987.

\section{Description}

A. General nontechnical description--A small greenish song bird approximately $11 \mathrm{~cm}$ long. Olive above, white below, and with yellowish flanks and wingbars. Males glossy black head contrasts with white spectacle. Females have dark gray head. Immature birds browner above, buffy below.

\section{B. Technical description}

1. Plumage and morphology--(Marshal et al. 1985). Adult male olive green on upper surface, white beneath with flanks faintly yellowish green. Crown and upper half of head is black, sharply demarcated. Black extends farther posteriorly on the crown and nape on males more than 1 year old than it does on first year males. The large, angular, white patch along the side of the head includes the lores and an interrupted eye-ring. It is broader than similar markings on the Solitary $(V$. solitarius) and Gray ( $V$. vicinior) Vireos. This white area is entirely surrounded by black. The white patches from the two sides converge becoming pointed anteriorly above the bill where they are separated by a speck of black. Black also encroaches across the super ciliary to the middle of the upper eyelid. Iris brownish red; bill black; feet plumbus. Wing and tail feathers dark olive, becoming blackish on the tertials and secondary coverts; all conspicuously rimmed with cream or lemon yellow. Rims broaden terminally on the coverts as conspicuous wing bars. The adult female is similarly colored except that the crown is slate gray, and the under parts are washed with greenish yellow. Immature specimens in fall plumage differ from adults by greener general coloration, a peculiar burnt umber wash along the flanks, and no head pattern, although the olive cap is grayer than the back. A mid-winter molt blackens the cap of all males. Males in their first year generally retain a gray cap, while older birds acquire a black cap.

2. Eggs--pure, unpatterned white, unique to the genus except $V$. nelsoni.

3. Body measurements (Tazik, unpublished data from Fort Hood, Texas)

$\begin{array}{lclc} & \mathbf{N} & \text { Mean } & \text { S.E. } \\ \text { Wing } & 188 & 56.9 & 0.059 \\ \text { Bill length } & 89 & 13.2 & 0.028 \\ \text { Tail } & 172 & 44.6 & 0.035 \\ \text { Weight } & 196 & 10.8 & 0.032\end{array}$

C. Vocalizations--(Marshall et al. 1985). Complicated song of phrases containing rapidly uttered notes that range widely in pitch, and are more musical and varied than that of other vireos. The most rapid of these are thrush-like. Tapes are on file at the Bioacoustic Archive, Florida State Museum, University of Florida (also Barlow 1981). Song similar to that of $V$. nelsoni except for a mandatory short trill in $V$. atricapillus that rounds off each phrase at a lower pitch than the body of the song. Alarm and conversation calls between members of a pair consist of a low harsh shrad; a di-di-di-di that may precede the shrad; various faint lisping notes and peeps; and a dividing of the shrad into a 
series of short, equal segments making a grating sound similar to the Ruby-crowned kinglet (Regulus calendula).

D. Local field characters--(Marshal et al. 1985). The striking head pattern is distinctive. Excepting $V$. nelsoni, the most similar plain greenish bird is the Solitary Vireo (V. solitarius) with its narrower white spectacles, and bluish gray cap that contrasts with the greenish back of all but the plumbeous races. However, the Solitary Vireo is much larger than the Black-capped and nests in a different habitat and geographic area. Its white eye ring cum lores is shaped like a candycane without the black interruption above the eye. $V$. nelsoni is similar in appearance to the female $V$. atricapillus, except that the former is darker, has a more olive green cap and duller body, and more cream-colored, less bright wing bars.

E. Identifying characteristics of material which is in interstate or international commerce or trade--Not applicable.

\section{F. Photographs and/or line drawings, if available}

1. Adults--Yes; most recent field guides; J.A. Grzybowski, Norman, OK; D.J. Tazik, Champaign, IL.

\section{Immatures--Unknown.}

3. Museum specimens--Oklahoma Museum of Natural History; National Museum of Natural History.

\section{Significance of taxon (Marshall et al. 1985)}

A. Natural--Locally common and an important ecological component of a very particular oak scrub habitat of its limited breeding range. It is an excellent indicator of the habitat type occupied because it is more narrowly restricted than any of its habitat associates, such as Yellow-breasted Chat (Icteria virens), Rufous-crowned Sparrow (Aimophila ruficeps), Painted Bunting (Passerina cirris), and Blackcrested Titmouse (Parus atricristatus). Along with the Golden-cheeked Warbler (Dendroica chrysoparia), one of the few species to nest on the steep rims of dry arroyos.

B. Human--The striking color pattern and effusive song make this is an especially attractive bird to omithologists and amateur birders, many of whom keep track of known nesting territories each year in various cities in Texas and Oklahoma. It is among the three most famous birds of Texas, the Golden-cheeked Warbler and Colima Warbler (Vermivora crissalis) being the other two. This vireo also is of considerable scientific interest because of its limited distribution, unclear relationship to $V$. nelsoni, and its distinction among vireos as the only species with white eggs, sexual dimorphism, winter molt of the crown, and striking face pattern.

\section{Geographic distribution}

A. Geographic Range--(Marshall et al. 1985). Formerly bred from Kansas through Oklahoma and Texas to central Coahuila, Mexico with an outlying or temporary colony in Nuevo Leon. Accidental summer records in Nebraska, New Mexico, Louisiana, and the base of Cerro Potosi, southern Nuevo Leon. Migrants are known from around the perimeter of the Mexican Plateau, winter residents from Sonora to Oxaca, but mostly in Sinaloa and Nayarit. The present breeding range is from south-central Oklahoma through central Texas to central Coahuila. 


\section{B. Precise occurrence}

1. Populations currently or recently known extant

a. Military

1. Fort Sill

a. Nation, State, County--USA, Oklahoma, Comanche County.

b. Latitude $34^{\circ} 40^{\prime} 00^{\prime \prime}$ to $34^{\circ} 45^{\prime} 00^{\prime \prime}$

Longitude $98^{\circ} 30^{\prime} 30^{\prime \prime}$ to $98^{\circ} 37^{\prime} 30^{\prime \prime}$

UTM Northing: ${ }^{38} 37^{000}$ to ${ }^{38} 42^{000}$

Easting: $\quad{ }^{38} 34^{500}$ to ${ }^{38} 43^{500}$

\section{c. Range, Township, Section}

T3N R13W Sec 24, 28, 31, 32

T3N R14W Sec 36

d. Pertinent 1:24000 US Geological Survey topographic quadrangles (7.5 minute series)

Quanah Mountain, OK, 1975

Mount Scott, OK, 1970

Fort Sill, OK, 1970

Arbuckle Hill, OK, 1970

e. Year of initial discovery--A record for the vireo on Fort Sill dates to 1943 (Grzybowski 1985a). More recent observations were made in 1985 by D. and T. Clark.

f. Year and nature of most recent observation or collection--Inventory and monitoring was conducted during 1988 through 1990 to evaluate status of the population (Grzybowski and Tazik 1990). Monitoring will continue in future years.

g. Location description--(see Figure 1 and $\mathbf{h}$ below).

h. Alternative site names--Colony site names and approximate locations follow:

$\begin{array}{lccc}\text { Site Name } & \text { Areas } & \text { Northing } & \text { Easting } \\ \text { Arapaho Point } & \text { J3 } & { }_{38}^{38} 38^{000} & { }_{5} 35^{000} \\ \text { Mount Sherman } & \text { J1 } & 3838^{500} & 5_{38}^{500} \\ \text { Pratt Hill } & \text { F2 } & 3841^{500} & { }^{5} 43^{500}\end{array}$




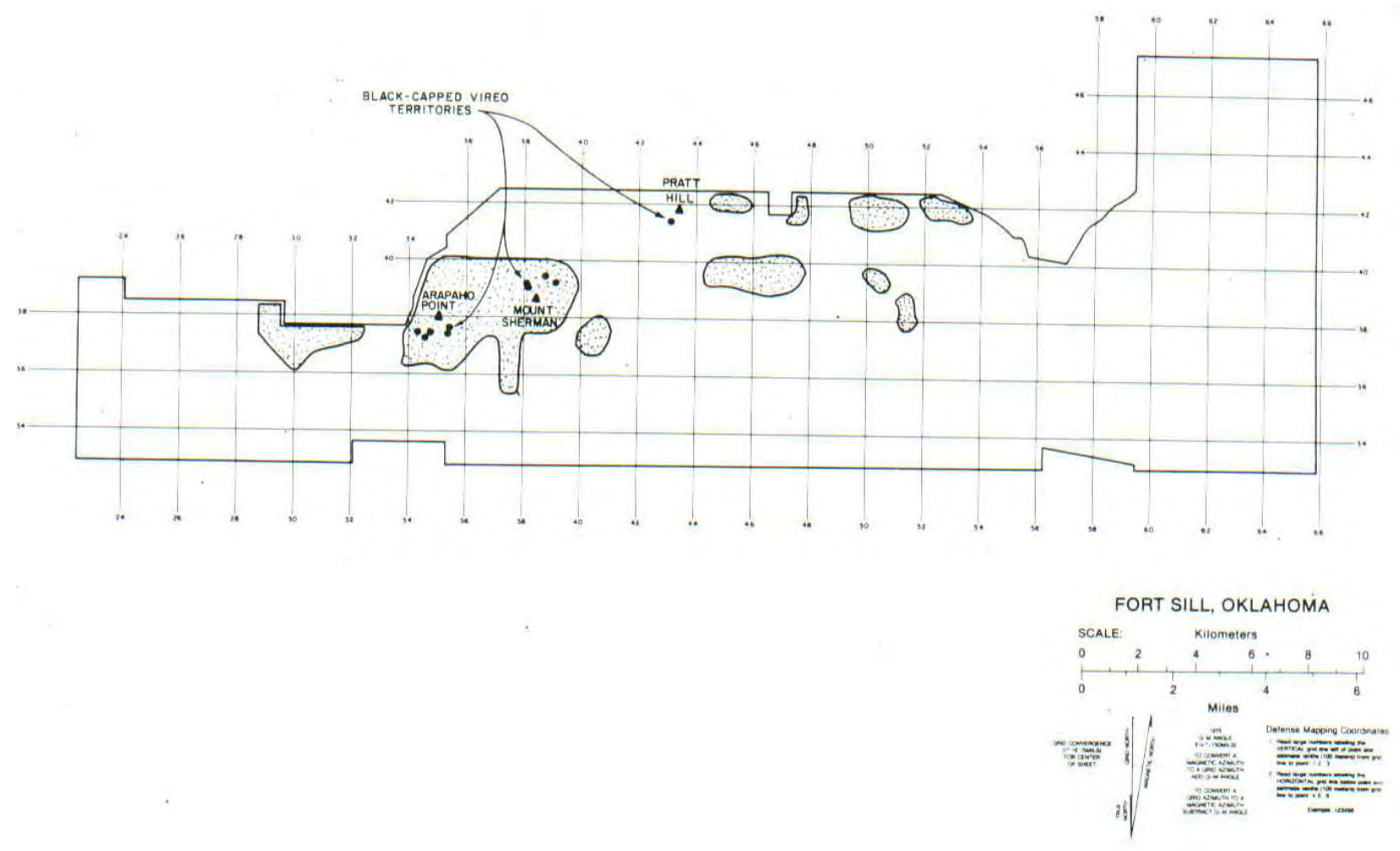

Figure 1. Location of Black-Capped Vireo Colony Sites on Fort Sill, Oklahoma during 1988 through 1990.

\section{Fort Hood}

a. Nation, State, County--USA, Texas, Bell and Coryell Counties.

b. Latitude $\quad 31^{\circ} 02^{\prime} 30^{\prime \prime}$ to $31^{\circ} 22^{\prime} 30^{\prime \prime}$

Longitude $\quad 97^{\circ} 30^{\prime} 00^{\prime \prime}$ to $97^{\circ} 52^{\prime} 30^{\prime \prime}$

UTM Northing: ${ }^{34} 36^{000}$ to ${ }^{34} 72^{000}$

Easting: $\quad{ }^{6} 07^{000}$ to ${ }^{6} 41^{000}$

c. Range, Township, Section--Not available.

d. Pertinent 1:24000 US Geological Survey topographic quadrangles (7.5 minute series)

Gatesville West, TX, 1979

Gatesville East, TX, 1979

Pidcoke, TX, 1958

Shell Mountains, TX, 1958

North Fort Hood, TX, 1958 
Leon Junction, TX, 1978

Twin Mountains, TX, 1978

Fort Hood, TX, 1978

Post Oak Mountain, TX, 1978

Bland, TX, 1978

Copperas Cove, TX, 1978

McMillan Mountains, TX, 1978

Killeen, TX, 1974

Nolanville, TX, 1974

e. Year of initial discovery--First reported in 1979 (Severinghaus et al. 1980). Rediscovered in 1985 by John Comelius (Fort Hood Fish and Wildlife Section).

f. Year and nature of most recent observation or collection--A status survey was conducted from 1987 through 1989. This resulted in complete enumeration of the population (Tazik et al. 1990a), habitat characterization (Tazik et al. 1990b), evaluation of population and nesting ecology (Tazik and Comelius 1990), and a biological assessment (Tazik et al. 1990c). Monitoring was conducted during 1990, and will continue in the future.

g. Location description--Colony sites are widely scattered over the entire parcel (see Figure 2 and below). Precise locations are available on the Fort Hood GRASS geographic information system.

h. Alternative site names--Known colony site names and approximate locations are as follows:

Site Name
Non-Live Fire Zone
Area 2 (AR 2)
Area 6 (AR 6)
Area 12 (AR12)
Red Bluff (REBL)
Brookhaven Mt. (BHMT)
Manning Mt. (MAMT)

Manning Mt. (MAMT)

Williamson Mt. (WMSP)

Shell Pt. (WMSP)

Northwest Fort Hood (NWFH)

West Fort Hood (WEFH)

\section{Training \\ Areas}

$\begin{array}{ccc}2,4,5 & { }^{34} 55^{000} & { }^{6} 32^{000} \\ 6 & { }^{34} 52^{000} & { }^{6} 39^{700} \\ 12 & { }^{34} 48^{000} & { }^{6} 29^{700} \\ 3 & { }^{34} 56^{000} & { }^{6} 35^{200} \\ 13 & { }^{34} 50^{000} & { }^{6} 31^{500} \\ 44 & { }^{34} 58^{200} & { }^{6} 16^{500} \\ 44 & { }^{34} 59^{000} & { }^{6} 16^{600} \\ 44 & { }^{34} 59^{800} & { }^{6} 17^{700} \\ 44 & { }^{34} 61^{000} & { }^{6} 18^{700} \\ 44 & { }^{34} 62^{700} & { }^{6} 15^{300} \\ 43 & { }^{34} 62^{000} & { }^{6} 10^{900} \\ 45 & { }^{34} 62^{200} & { }^{6} 11^{800} \\ 51 & { }^{34} 69^{800} & { }^{6} 13^{400} \\ 52 & { }^{34} 71^{000} & { }^{6} 13^{500} \\ 53 & { }^{34} 67^{200} & { }^{6} 16^{300} \\ 22 & { }^{34} 40^{000} & { }^{6} 07^{000} \\ 24 & { }^{34} 37^{500} & { }^{6} 07^{600}\end{array}$


Live Fire Zone

Area 75 (AR75)

Robinette Point (ROPT)

Rambo Point (RAPT)

Brown's Creek (BCRA)

Jack Mt. (JAMT)

Ruth Cemetery (RUCE)

Dalton Mt. (DAMT)

Henson Mt. (HEMT)

Area 81 (AR81)

Lone Mt. (LOMT)

Pilot Knob Range (PKRA)

$\begin{array}{lll}75 & { }^{34} 57^{000} & { }^{6} 27^{900} \\ 80 & { }^{34} 59^{800} & { }^{6} 20^{700} \\ 80 & { }^{34} 59^{000} & { }^{6} 22^{500} \\ 66 & { }^{34} 60^{800} & { }^{6} 23^{500} \\ 65 & { }^{34} 63^{200} & { }^{6} 18^{800} \\ 82 & { }^{34} 57^{000} & { }^{6} 17^{500} \\ 64 & { }^{34} 66^{000} & { }^{6} 24^{000} \\ 61 & { }^{34} 68^{700} & { }^{6} 22^{800} \\ 63 & 3466^{700} & { }^{6} 20^{500} \\ 81 & { }^{34} 56^{000} & { }^{6} 26^{600} \\ 91 & { }^{34} 49^{700} & { }^{6} 18^{400} \\ 91 & { }^{34} 48^{500} & { }^{6} 18^{000} \\ 82 & { }^{34} 47^{800} & { }^{6} 20^{200}\end{array}$

\section{Camp Bullis Training Site}

a. Nation, State, County--USA, Texas, Bexar and Comal Counties.

b. Latitude $29^{\circ} 37^{\prime} 30^{\prime \prime}$ to $29^{\circ} 42^{\prime} 30^{\prime \prime}$

Longitude $98^{\circ} 32^{\prime} 30^{\prime \prime}$ to $98^{\circ} 37^{\prime} 30^{\prime \prime}$

UTM Northing: ${ }^{32} 78^{800}$ to ${ }^{32} 86^{000}$

Easting: ${ }^{5} 37^{000}$ to ${ }^{5} 43^{500}$

c. Range, Township, Section--Not available.

d. Pertinent 1:24000 US Geological Survey topographic quadrangles (7.5 minute series)

Castle Hills, TX 1973

Bergheim, TX 1973

Camp Bullis, TX

e. Year of initial discovery--There is a report of a sighting before 1977 (Pulich 1976). Further documentation was obtained during 1989 (Shaw et al. 1990).

f. Year and nature of most recent observation or collection--During 1990, a resurvey was completed that confirmed results of the 1989 survey (Rust and Tazik 1990). Territories were mapped and nesting data were obtained.

g. Location description--(see Figure 3 and below).

h. Alternative site names--Site names and approximate locations follow:

\begin{tabular}{lccc} 
& \multicolumn{3}{c}{ Training } \\
Site Name & Areas & $\begin{array}{c}\text { Northing } \\
{ }^{32} 85^{900}\end{array}$ & Easting \\
King's Ridge & 1 & $42^{800}$ \\
Otis Ridge & 7,8 & ${ }^{32} 81^{900}$ & $541^{900}$ \\
Hogan Ridge & 8 & ${ }^{32} 79^{500}$ & ${ }^{5} 42^{500}$ \\
Davis Ridge & 8 & ${ }^{32} 78^{900}$ & ${ }^{5} 43^{100}$ \\
Aue Hill & 14 & ${ }^{32} 82^{100}$ & ${ }^{5} 37^{500}$
\end{tabular}




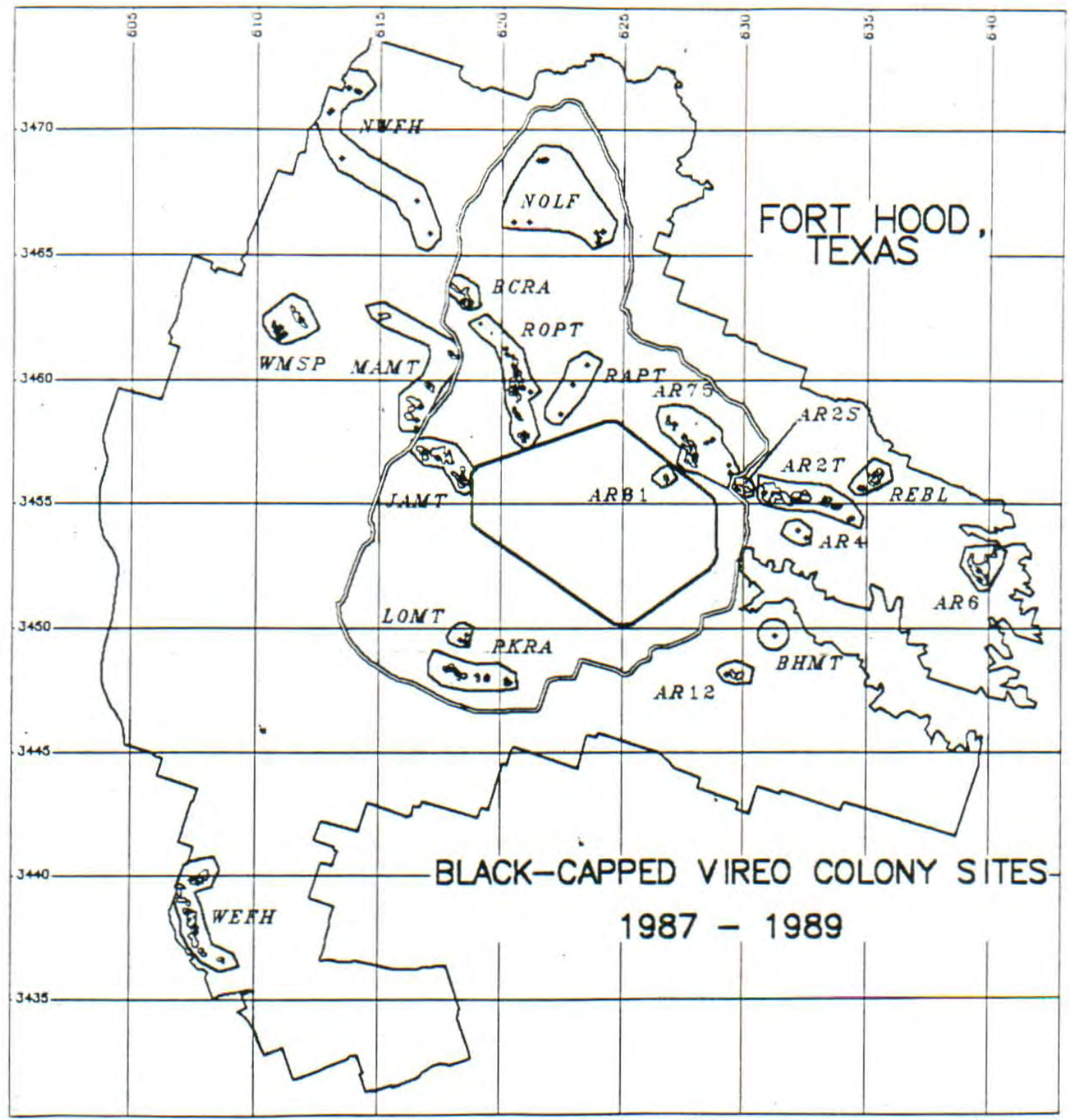

Figure 2. Location of Black-capped Vireo Colony Sites on Fort Hood, Texas during 1987 through 1990. 


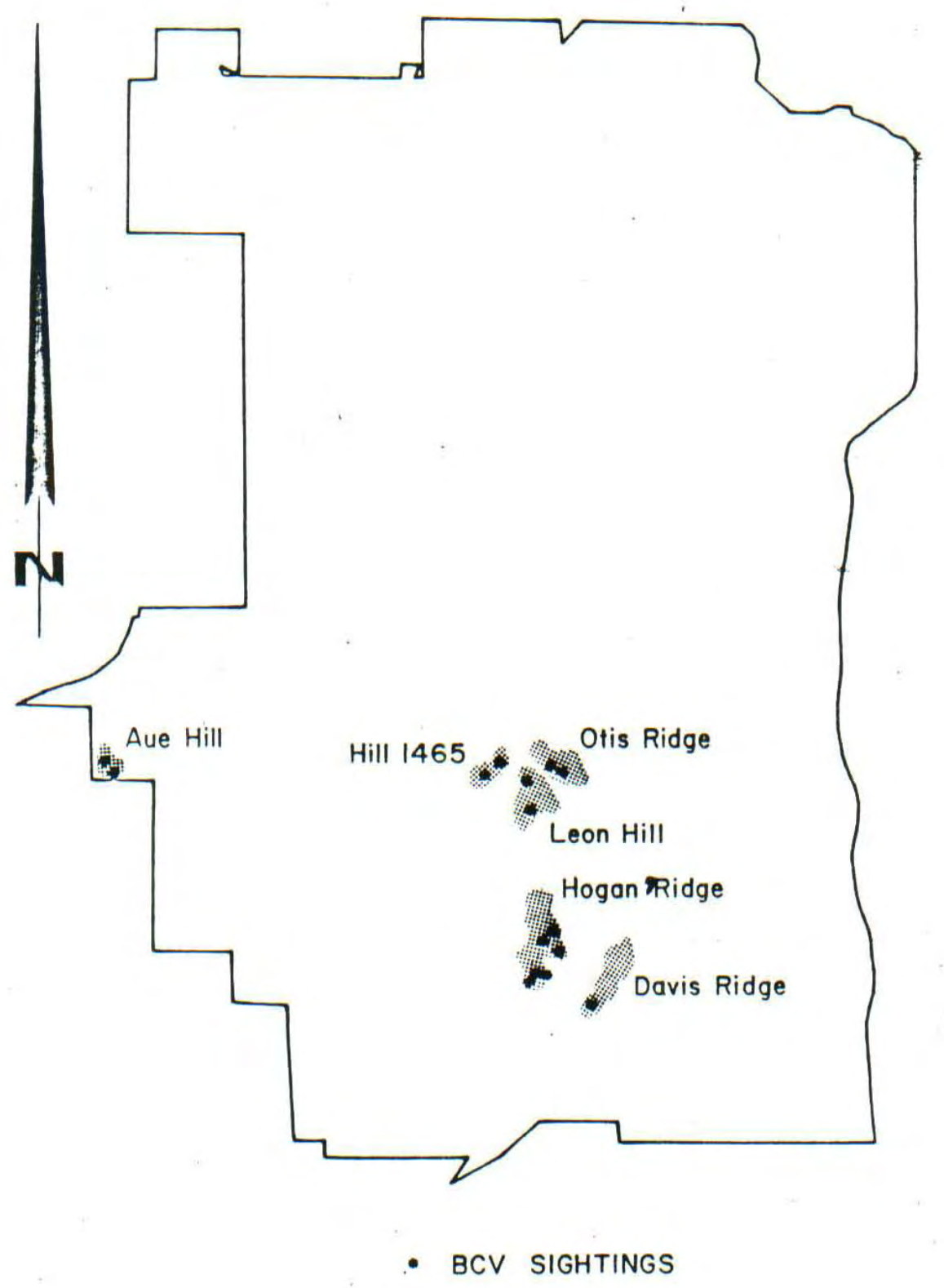

Figure 3. Locations of black-capped Vireo sightings on Camp Bullis during 1989. 


\section{b. Nonmilitary locations (general)}

\section{Oklahoma (breeding)}

a. Blaine County--Salt Creek

b. Caddo County--Scott

c. Canadian County--Niles, Methodist Canyon Camp, and County Line.

d. Comanche County--Wichita Mountains National Wildlife Refuge [Hobbs Canyon, Cedar Mountain, Panther Creek, Greenleaf Canyon, North Mountain, Moko, Mountain, Elk Mountain, Charons Garden].

\section{Texas (breeding)}

a. Bandera County--Lost Maples State Park.

b. Bexar County-- Friedrich Park.

c. Blanco County--East of Blanco.

d. Brewster County--Big Bend National Park.

e. Burnett County--Marble Falls.

f. Coke County--Callahan Divide.

g. Crockett County--Fort Lancaster Ruins.

h. Dallas County--Greenhills Environmental Center.

i. Edwards County

1. Highway 674,17 miles south of Rocksprings

2. Nueces River 3 miles south of Barksdale.

j. Erath County--Bluff Dale.

k. Irion County--observed in center of county in 1977.

1. Kerr County

1. West Spicer Drive at Dewberry Hollow, previously Lacey's Ranch and many eggs. Many nests and study skins in museum collections were taken from this location.

2. Vicinity of Harper--Reservation, Lazy, and Elm Pass Roads.

3. Yo Ranch west of Mountain Home. 
4. Kerr Wildlife Management Area.

5. South Fork Ranch.

m. Kimble County--Walter Buck Wildlife Management Area.

n. Pecos County--Highway 285 Roadside Park (1974).

o. Somerville County

1. Picnic Area on Highway 67 near Chalk Mountain.

2. Dinosaur Valley State Park.

p. Sutton County--Devil's River.

q. Taylor County--Highway 277 northwest of Abilene State Recreational Area.

r. Terrell County--Mouth of Independence Creek.

s. Tom Green County--S Ranch.

t. Travis County

1. Wild Basin and Davenport Ranch.

2. Nameless Valley Ranch and Nameless Valley Road.

3. South and west of Four Points.

4. Bull Creek north of Highway 360.

5. City Park Road.

u. Uvalde County--Neal's Lodge.

\section{Mexico (breeding)}

\section{a. Coahulia}

1. $29^{\circ} 00^{\prime} \mathrm{N}, 102^{\circ} 00^{\prime} \mathrm{W}$

2. $28^{\circ} 39^{\prime} \mathrm{N}, 102^{\circ} 19-20^{\prime} \mathrm{W}$

3. $27^{\circ} 06^{\prime} \mathrm{N}, 102^{\circ} 26^{\prime} \mathrm{W}$

4. $26^{\circ} 27^{\prime} \mathrm{N}, 101^{\circ} 34^{\prime} \mathrm{W}$

4. Mexico (migrants)

a. Nuevo Leon-- $26^{\circ} 02^{\prime} \mathrm{N}, 99^{\circ} 45^{\prime} \mathrm{W}$ 
b. Tamaulipas-- $23^{\circ} 36^{\prime} \mathrm{N}, 99^{\circ} 13^{\prime} \mathrm{W}$

c. Hidalgo--Jacala.

5. Mexico (winter)

a. Sinaloa--Concordia

b. Nayarit

1. El Pescadaro.

2. Jumatan to El Espino, northwest of Tepic.

3. 5 miles northwest of Tepic.

4. Las Varas.

\section{Populations extirpated}

a. Kansas--formerly recorded in Doniphan, Riley, Harvey Cowley, Hodgeman, Gray, and Comanche Counties (Graber 1957).

b. Oklahoma--formerly reported from Beaver, Alfalfa, Major, Dewey, Payne, Creek, Tulsa, Logan, Oklahoma, Cleveland, Gravin, Murray, and Kiowa Counties (Grzybowski, et al. 1986).

c. Texas--formerly known from Bastrop, Callahan, Cameron, Comal, Comanche, Concho, Eastland, Ellis, Fayette, Gillespie, Hays, Kendall, Kinney, Lee, Llano, Mason, McLennan, Medina, Menard, Reagan, Real, Tarant, and Valverde Counties (Graber 1957).

d. Mexico--unknown.

3. Historically known population where current status is not known--unknown.

4. Locations not yet investigated believed to support additional populations--Access to private lands in Texas has hindered location of existing populations. The total population probably is much larger than the presently documented population of 1500 to 2000 adults (Grzybowski, pers. commun.).

\section{Biogeographical and phylogenetic history of taxon--Incomplete}

\section{General environment and habitat description}

A. Concise statement of general environment and habitat--Found in midsuccessional hardwood scrub that exhibits a patchy or clumped distribution and hardwood foliage to ground level. Trees are sometimes scattered through the brush. Scruby oaks (Quercus) often dominate or are a major feature of the habitat. Areas with dense live juniper (Juniperus) typically are avoided. Preferred habitat often results from fire within stands of mature oak-juniper, but may develop from other disturbances as well. Habitat remains suitable for 5 to 25 years after fire. Steep rocky slopes where erosion and boulders hold back succession can maintain habitat for long periods. 


\section{B. Physical characteristics}

\section{Climate}

a. Koppen climate classification (Visher 1954).

1. Fort Sill--Cfa: warm temperate climate with rains at all seasons and warm summers; average January temperature below $18^{\circ} \mathrm{C}$ but above $0^{\circ} \mathrm{C}$; no dry season; driest summer month receives greater than $3 \mathrm{~cm}$ of rain; average temperature of warmest month above $22^{\circ} \mathrm{C}$.

2. Fort Hood--Cfa: as above.

3. Camp Bullis--Cfa: as above.

4. Other parts of range--BSw: steppe climate with dry winters. BShw: excess of evaporation over precipitation; precipitation numerically greater than 14 plus the temperature $\left({ }^{\circ} \mathrm{C}\right)$ but less than 14 plus twice the temperature.

b. Regional macroclimate (Bailey 1980).

1. Fort Sill--Lies within the Tall Grass Prairie Province. Annual precipitation approaches $100 \mathrm{~cm}$. Average annual temperature $18^{\circ} \mathrm{C}$.

2. Fort Hood--Lies within the Prairie Brushland Province where summers are long and hot and winters short and mild. Annual temperatures average 15 to $20^{\circ} \mathrm{C}$. The frost-free seasons ranges from 250 to 300 days. Precipitation ranges from 50 to $75 \mathrm{~cm}$ and falls primarily during the growing season. Annual evaporation is 180 to $200 \mathrm{~cm}$. From May to October, potential evaporation is about twice the precipitation.

3. Camp Bullis--same as at Fort Hood.

c. Local microclimate

1. Fort Sill (NOAA 1982; based on Lawton, OK)

a. Mean annual precipitation--29.2 inches.

b. Mean annual temperature-- $62.1^{\circ} \mathrm{F}$.

c. Mean monthly precipitation and temperature

$\begin{array}{lccc}\text { Month } & \begin{array}{c}\text { Precipitation } \\ \text { (inches) }\end{array} & \begin{array}{c}\text { Temperature }\left({ }^{\circ} \mathbf{F}\right) \\ \text { Minimum }\end{array} \\ \text { Jan } & 1.07 & 51.2 & 26.3 \\ \text { Feb } & 1.17 & 56.8 & 30.5 \\ \text { Mar } & 1.83 & 65.5 & 38.4 \\ \text { Apr } & 2.41 & 75.5 & 49.8 \\ \text { May } & 5.69 & 82.7 & 58.3 \\ \text { Jun } & 3.57 & 90.9 & 67.0 \\ \text { Jul } & 2.51 & 96.4 & 71.0\end{array}$




$\begin{array}{llll}\text { Aug } & 2.15 & 95.9 & 69.5 \\ \text { Sep } & 2.98 & 87.9 & 62.2 \\ \text { Oct } & 2.85 & 77.5 & 50.4 \\ \text { Nov } & 1.75 & 63.5 & 38.2 \\ \text { Dec } & 1.22 & 54.7 & 29.7\end{array}$

2. Fort Hood (NOAA 1982; based on Temple, TX)

a. Mean annual precipitation--33.75 inches.

b. Mean annual temperature-- $66.6^{\circ} \mathrm{F}$.

c. Mean monthly precipitation and temperature

$\begin{array}{lrcc}\text { Month } & \begin{array}{c}\text { Precipitation } \\ \text { (inches) }\end{array} & \begin{array}{c}\text { Temperature }\left({ }^{\circ} \mathbf{F}\right) \\ \text { Maximum }\end{array} & \begin{array}{c}\text { Minimum } \\ \text { Jan }\end{array} \\ \text { Feb } & 1.94 & 57.4 & 35.7 \\ \text { Mar } & 2.57 & 61.6 & 39.0 \\ \text { Apr } & 1.97 & 69.5 & 45.9 \\ \text { May } & 3.56 & 77.6 & 55.7 \\ \text { Jun } & 4.65 & 83.7 & 63.3 \\ \text { Jul } & 2.94 & 91.3 & 70.2 \\ \text { Aug } & 1.75 & 95.7 & 73.5 \\ \text { Sep } & 2.50 & 95.9 & 73.0 \\ \text { Oct } & 3.51 & 89.5 & 67.8 \\ \text { Nov } & 3.30 & 80.6 & 57.2 \\ \text { Dec } & 2.69 & 68.1 & 45.7 \\ & 2.69 & 60.9 & 38.4\end{array}$

3. Camp Bullis (NOAA 1982; based on San Antonio, TX)

a. Mean annual precipitation--29.13 inches.

b. Mean annual temperature-- $68.7^{\circ} \mathrm{F}$.

c. Mean monthly precipitation and temperature

$\begin{array}{lccc}\text { Month } & \begin{array}{c}\text { Precipitation } \\ \text { (inches) }\end{array} & \begin{array}{c}\text { Temperature }\left({ }^{\circ} \mathbf{F}\right) \\ \text { Minimum }\end{array} \\ \text { Jan } & 1.55 & 61.7 & 39.0 \\ \text { Feb } & 1.86 & 66.3 & 42.4 \\ \text { Mar } & 1.33 & 73.7 & 49.8 \\ \text { Apr } & 2.73 & 80.3 & 58.8 \\ \text { May } & 3.67 & 85.5 & 65.5 \\ \text { Jun } & 3.03 & 91.8 & 72.0 \\ \text { Jul } & 1.92 & 94.9 & 74.3 \\ \text { Aug } & 2.69 & 94.6 & 73.7 \\ \text { Sep } & 3.75 & 89.3 & 69.4 \\ \text { Oct } & 2.88 & 81.5 & 58.9 \\ \text { Nov } & 2.34 & 70.7 & 48.2 \\ \text { Dec } & 1.38 & 64.6 & 41.4\end{array}$


2. Air and water quality requirements--unknown.

3. Physiographic province--Primarily Edward's Plateau and Osage Plains within the Great Plains (Robbins et al. 1986).

4. Physiographic and topographic characteristics-- Distribution of potential habitat is related to elevation, slope, and aspect (Tazik et al. 1990a). Observed primarily on upland plateau remnants, side slopes, and bouldered hillsides supporting preferred habitat. At Fort Hood, preferences are for elevations over 300 meters, slopes over 10 percent, and west facing slopes.

5. Edaphic factors--Distribution of potential habitat also is related to geology and soils (Tazik et al. 1990a). Upland soils over both loose and dense limestone are preferred on Fort Hood, Texas; i.e., Ekrant and Real-Rock soils over Edward's and Comanche Peak Limestone.

6. Dependence of this taxon on natural disturbance--Habitat usually results from fire in stands of mature oak- juniper woodland. Other disturbance that sets back succession may also lead to suitable habitat.

7. Other unusual features--unknown.

\section{Biological characteristics}

\section{Vegetation physiognomy and community structure}

a. General--Preferred habitat is dominated by hardwood scrub although live and dead trees may be scattered among clumps of brush. Hardwood foliage extends from ground level mostly up to about 3 meters in height. Extensive tree growth and juniper invasion makes habitat less desirable. Species commonly found in vireo territories on Fort Hood include shin oak $(Q$. sinuata), flame-leaved sumac (Rhus lanceolata), ashe juniper (J. ashii), Texas oak (Q. texana), skunkbush sumac $(R$. aromatica), red bud (Cercis canadensis), and Texas ashe (Fraxinus texensis). On Fort Sill, black-jack oak ( $Q$. marilandica) was the dominant woody plant species. While plant species composition of the habitat varies throughout the range, habitat structure appears to be consistent.

b. Nest sites--Most commonly used nest substrates in order of importance on Fort Hood are shin oak, Texas oak, red bud, Texas ashe, flame-leaved sumac, ashe juniper, Carolina buckthorne (Rhamnus caroliniana), and Mexican buckeye (Ugnadia speciosa). Pendulent nests are located in narrow stemmed forks of woody vegetation. Nest height averages about 1 meter above ground, with 95 percent of nests between 0.5 and 2.0 meters.

c. Foraging sites--Foliage gleans among woody vegetation in shrub and lower canopy layers; never on the ground. Foraging substrate selection has not been quantified.

\section{Regional vegetation type (Bailey 1980).}

a. Fort Sill--Tall-Grass Prairie Province: includes tall and mid-grasslands. Woody vegetation is rare except on the cottonwood floodplains.

b. Fort Hood--Prairie Brushland Province: arid grasslands with shrubs and low trees growing singly or in small clumps. On the Edward's Plateau, oak and juniper often are mixed with grasses and/or mesquite. 


\section{c. Camp Bullis--Same as Fort Hood.}

3. Frequently associated species--A wide variety, but most commonly Black-crested Titmouse (Parus atricristatus), Yellow-breasted Chat (Icteria virens), Bewick's Wren (Thryomanes bewickii), Rufous-crowned Sparrow (Aimophila ruficeps), Northern Cardinal (Cardinalis cardinalis), and Painted Bunting (Passerina ciris). The Bell's $(V$. belli) and White-eyed $(V$. griseus) Vireos often occur in the same or adjacent habitats.

4. Dominance and frequency--not applicable.

5. Successional phenomena--not applicable.

6. Dependence on dynamic biotic features--Habitat is mostly ephemeral, requiring periodic maintenance using fire or mechanical means to remove junipers and to maintain cover dominated by hardwoods up to about 3 meters.

7. Other endangered species--Although not usually in the same habitat, the federally endangered Golden-cheeked Warbler (Dendroica chrysoparia), may be found in adjacent mature oak-juniper woodlands.

\section{Population biology}

A. General summary--A review by Marshall et al. (1985) put the adult breeding population at about 592 to 1,130 -- Oklahoma-120, Texas-376 to 748, Mexico-96 to 262 . Recent discoveries increase the documented population to about 1,500. The actual population probably is much larger as there undoubtedly are many as yet undiscovered populations on private lands within Texas and in Mexico.

\section{B. Demography}

\section{Known population}

a. Texas--Numerous populations throughout central Texas now amount to over 1,000 known breeding adults (Marshall et al. 1985, Grzybowski 1989a). Recently, Grzybowski estimated that there may be 1,000 adults in Kerr County alone. The most significant populations occur at Fort Hood (280), Devil's River (circa 200), Kickapoo Caverns State Park (circa 160), and Kerr Wildlife Management Area (70 to 75). Others include Lost Maples State Natural Area (40), South Fork Ranch (32-33), Walter Buck Wildlife Management Area (20), and Davenport Ranch/Wild Basin (29) (Grzybowski 1989a). An exhaustive list is presented by Marshal et al. (1985).

b. Oklahoma--102 to 106 adults were observed at eight localities during 1987 (Grzybowski 1988a). The most significant population remains on the Wichita Mountains National Wildlife Refuge adjacent to Fort Sill in Comanche County (86 to 88 adults). During 1990, 120 to 131 adult vireos were observed within the Wichita Mountains (Grzybowski 1989b). Others occur in Blaine, Canadian, and Caddo Counties.

c. Mexico--Marshall et al. (1985) estimate 96 to 262 adults.

\section{Demographic details}

\section{a. Fort Sill, Oklahoma}


1. Area of population--Less than 20 to 40 ha.

2. Number and age class--17 to 18 adults recorded in 1988, 6 in 1989, and 8 in 1990.

3. Density--Unknown.

4. Evidence of reproduction--Several nests recorded during 1987 through 1990.

5. Evidence of population expansion or decline-- Oklahoma population is gravely endangered. Number on Fort Sill may be dependent upon production on the adjacent Wichita Mountains National Wildlife Refuge.

\section{b. Fort Hood, Texas}

1. Area of population--550 ha in numerous colony sites.

2. Number and age class-- 277 adults in 143 territories were documented in 1989. Population included approximately 36 second year (SY) and 241 after second year (ASY) adults.

3. Density--Territory size averaged 3.61 ha yielding 27.7 territories per 100 ha of occupied habitat. As 93.8 percent of males were mated, this yields about 52 adults per 100 ha of occupied habitat.

4. Evidence of reproduction--423 nestings were observed over a 4-year period from 1987 through 1990.

5. Evidence of population expansion or decline--Annual population appears stable, but regional population may be in decline. This is suggested by the low number of SY birds present. The Fort Hood population may be held stable by immigration from areas offpost.

\section{c. Camp Bullis Training Site, Texas}

1. Area of population--50 ha during 1990.

2. Number and age class--Approximately 35 to 36 adults estimated in 1989 and 1990.

3. Density--Twelve territories averaged 2.8 ha, yielding 36 territories per 100 ha.

4. Evidence of reproduction--Three nests were observed in 1990.

5. Evidence of population expansion or decline--Unknown.

\section{Phenology}

1. Patterns--Individuals migrate north to arrive at breeding areas during March and April. Return migration takes place during August and September.

2. Relation to climate--Individuals arrive later on breeding sites in the northern part of the range than in the southern part. Graber $(1957,1961)$ thought that climate might be a factor limiting the northward expansion of the range. 


\section{Reproductive biology}

1. Mating System--Monogamous.

2. Type of Reproduction--Sexual.

3. Mode of Reproduction--Pairs build nests in which up to 4 eggs are deposited. The nest cycle includes: construction (4-5 days), inactive construction (1 day), laying (4 days), incubation (14-17 days beginning after egg 2 or 3 ), brooding of nestlings (11 days), and fledgling (40+ days) (Graber 1961). Pairs will renest many times after unsuccessful nests.

4. Overall assessment of taxon's reproductive success--Poor success has been recorded throughout its range due to the effects of cowbird nest parasitism. Nest success among unparasitized nests on Fort Hood was estimated at 2 times that of parasitized nests ( 25 vs 12 percent) (Tazik and Cornelius 1990): Efforts to control cowbirds on Fort Hood have been unsuccessful. Cowbird control has not been attempted on Camp Bullis nor on Fort Sill. Cowbird parasitism ranged from 65 to 91 percent on Fort Hood during 1987 to 1990 (Tazik and Cornelius 1990), and has averaged about 73 percent throughout the range (Grzybowski 1989a). Predation also is an important factor limiting reproductive success and may become more important with a reduction in cowbird parasitism.

\section{Population ecology of species}

A. General summary of population of taxon--Black-capped Vireos typically reproduce most successfully in colony sites where individuals reenforce each others singing and other reproductive behavior. The species appears well adapted to locating new habitat patches away from natal sites.

B. Positive or neutral interactions with other species --Co-exists with a wide variety of song bird species.

\section{Negative interactions with other species}

1. Predators--Direct predation of adults rarely has been observed.

2. Parasites--Appears to be unusually free of ectoparasites and disease (Graber 1961).

\section{Competition}

a. Intraspecific--Mated pairs are territorial.

b. Interspecific--Although territories sometimes overlap with those of the White-eyed and Bell's Vireos, direct competition has not been observed.

\section{Foraging ecology and food resources}

The vireo is a foliage gleaning insectivore that forages among the trees and shrubs in its habitat. It does not feed on the ground (Graber 1961). Foraging substrate preferences have not been quantified.

Various insect larvae constitute the bulk of the diet. Lepidopteran larvae predominate followed by Coleopteran larvae. Other animal matter include spiders, centipedes, Neuroptera, Odonata, Hemiptera, and Homoptera. The young are fed small larvae, with food items increasing in size as the young grow. Grasshoppers and other Orthopterans may contribute as much as one-third of their diet. 


\section{E. Hybridization}

1. Naturally occurring--Unknown.

2. Artificially induced--Unknown.

F. Other factors of population ecology

1. Survivorship--Adult annual survivorship estimated at 60 percent for major colony sites on Fort Hood. Small satellite colony sites tend to exhibit a lower return frequency than large colony sites (Grzybowski 1990).

2. Military impacts--There is no evidence of significant impact of military activity on survivorship or reproductive success. However, although military activity appears to have benefitted the species as a result of fire frequency, there is the potential for significant impacts if colony sites are inadequately protected from tactical vehicle activity.

\section{Current land ownership and management responsibility}

A. General--Federal, Department of Defense.

B. Specific landowner--U.S. Army.

1. Fort Sill-- 38,160 ha.

2. Fort Hood--87,890 ha.

3. Camp Bullis-- 11,280 ha.

\section{Management responsibility}

1. Fort Sill--Gene Stout, Natural Resources Division, DEH, Fort Sill, OK.

2. Fort Hood--Dennis Herbert, Fish and Wildlife Section, DEH, Fort Hood, TX.

3. Camp Bullis--Dusty Bruns, Land Management Office, Camp Bullis Training Site, Fort Sam Houston, TX.

D. Easements, conservation restrictions, etc.--None.

\section{Management practices and experiences}

\section{A. Habitat Management}

\section{Review of past management and land use experiences}

a. General

1. Fort Sill--Established as an isolated cavalry post in 1869 . The area was sparsely populated by Indian tribes for several thousand years before this time. The only major disturbances were from bison grazing and fires of natural or Indian origin (Johnson et al. 1990). The fort has been an artillery training center since 1946. Various grazing and 
farming activities did occur before acquisition of a large part of the area in 1940. Since 1957, there has been no domestic grazing on the post. However, grazing of buffalo and long-horn cattle is managed on the adjacent Wichita Mountains National Wildlife Refuge. About 3,360 ha are used for the cantonment area, 32,000 for training areas, and 3,200 for nonfiring activities. Approximately 14,160 ha are leased for haying. A total of 840 ha are under oil and gas leases.

2. Fort Hood (Nakata 1987)--A military presence was first established in the region in 1849 with Fort Gates on the Leon River. The post was established to protect settlers from Indians. A more extensive training camp was established in 1942 to prepare troops for World War II tank destroyer combat. Since 1946, the post has housed and supported various armored divisions and since 1971 has been the only installation with two divisions. Historically, the area has been heavily grazed by cattle. The present lease agreement allows up to 3500 animal. The live fire zone includes over 25,100 ha, including a 8,700 ha multipurpose maneuver area. Maneuver areas comprise about 53,400 ha. Controlled burns and mechanical methods have been used to improve range conditions -- primarily removal of ashe juniper. During 1986 through 1989, nearly 10,000 ha were mechanically or hand cleared, while 13,760 ha, primarily grasslands, were burned.

3. Camp Bullis (Bruns 1988)--Historically, this region was inhabited by hunting and gathering Indian tribes. An Army instruction camp, then known as Camp Funstun, was established between 1906 and 1908, and was used about 3 months per year until 1915 when it was occupied by the 3rd Brigade Maneuver Division. What became known as Camp Bullis in 1919, expanded to 11,280 ha by 1941 . During World Wars I and II, the Camp was used for rifle and field training. The area continues to be used for field training and known distance firing. The area is grazed by cattle. Chemical and mechanical means as well as controlled fires are used to control vegetation in order to improve range conditions. Up to 160 ha of ashe juniper per year are controlled by these methods.

b. This taxon--Past management actions have not been directed at this taxon on any of these installations. However, in general, fires set by Indians prior to extensive settling of the region may have created much habitat.

\section{Performance under changed condition}

a. Fort Sill--Habitat here appears to exist under natural conditions. Military activities normally do not infringe on these areas. However, reproduction has been poor due to nest parasitism by the Brown-headed Cowbird which appears to travel to existing colony site locations from the Wichita Mountains National Wildlife Refuge.

b. Fort Hood--The increased fire frequency due to military activities appears to have created much of the existing habitat on the installation. However, the unnatural abundance of cowbirds in the region due to extensive cattle grazing has reduced reproductive success.

c. Camp Bullis--Habitat here also has been enhanced by military activity. The extent of cowbird parasitism has not been documented to date. 
3. Current management policies and actions--Management authorities on each installation are well aware of the requirements of the vireo. Each installation has established a proactive policy for compliance with the Endangered Species Act, and for development of protection and management plans.

a. Fort Sill--This vireo population has been studied from 1988 through 1990. An endangered species management plan will be prepared during 1991.

b. Fort Hood--Studied since 1987, a biological assessment is in preparation. Colony sites are being signed, and guidelines have been issued to troops to ensure protection. Fires are closely tracked to prevent inadvertent destruction of known colony sites. Vegetation control activities are coordinated through the Fish and Wildlife Section.

c. Camp Bullis--Inventories were conducted during 1989 and 1990. Land use activities are being monitored to avoid any harm to the population.

4. Future land use--Military activities and other existing land uses will continue on each area for the foreseeable future. At Fort Hood, the existing cattle grazing regime may be modified significantly or eliminated. Such action may benefit a wide variety of song birds including the vireo and the endangered Golden-cheeked Warbler, and enhance the capability of the land to support continued maneuver training.

B. Cultivation--Not applicable.

\section{Evidence of threats to survival}

A. Present or threatened destruction, modification, or curtailment of habitat or range--Continuation of Army mission activities is not an unavoidable threat to the vireo's habitat. In fact, military activity appears to have enhanced availability of the habitat.

1. Past threat--In recent times, probably same as existing threats.

2. Existing threat--Major threats throughout the range of the vireo include: (i) loss of habitat due to urban development, excessive rangeland improvement, grazing by domestic herbivores, and natural succession including invasion of junipers; and (ii) cowbird nest parasitism.

a. Fort Sill--Cowbird parasitism.

b. Fort Hood--Cowbird parasitism, and exposure to tactical vehicle training.

c. Camp Bullis--Possibly cowbird parasitism.

\section{Potential threat}

a. Fort Sill--Initiation of military activities within existing colony sites could be detrimental.

b. Fort Hood--Loss of habitat due to natural succession; maneuver damage to habitat could occur although it does not appear to have been a problem to date.

c. Camp Bullis--Loss of habitat due to natural succession. 
B. Over-utilization for commercial, sporting, scientific, or educational purposes

1. Past threat--Unknown.

2. Present threat--The Black-capped Vireo is attractive to both professional and amateur ornithologists. Nests have failed or were abandoned because of excessive activities of photographers.

\section{Potential threat--Unknown.}

\section{Disease or predation}

\section{Past threat--Unknown.}

2. Present threat--Remarkably free of ectoparasites and disease (Graber 1961). However, eggs and young are subject to predation. On Fort Hood, over 27 percent of nests were destroyed mostly due to predation. Major predators include snakes, birds (e.g., jays), small and medium-sized mammals, and ants.

3. Potential threat--A reduction in cowbird parasitism likely will result in a higher incidence of predation.

\section{Inadequacy of existing regulatory mechanisms}

1. Past threat--Prior to listing as a federally endangered species, existing regulations were inadequate to protect the vireo's habitat.

2. Present threat--The Endangered Species Act does provide adequate protection for the species on federal lands including the three Army installations discussed here. However, enhancement of the existing populations and ultimate recovery of the species depends on a proactive approach to management on the part of the Army.

\section{Potential threat--Unknown.}

\section{E. Other natural or manmade factors}

\section{Past threat--Unknown.}

2. Present threat--The greatest existing threat to the Black-capped Vireo throughout its range is nest parasitism by the Brown-headed Cowbird. Within the range of the vireo, the abundance of cowbirds is primarily the result of extensive cattle grazing and feedlots. From 1987 through 1990, the incidence of parasitism among Fort Hood vireos ranged between 65 and 90 percent. Parasitized nests were found to be subject to higher rates of nest desertion during incubation and higher levels of destruction during the nestling stage than unparasitized nests (Tazik and Cornelius 1990). Nesting success among parasitized nests was about half that of unparasitized nests. Production was reduced by as much as 42 to 86 percent.

3. Potential threat--Military activity on each of the installations is a potential threat to individual vireo colony sites, although no serious habitat destruction has been documented to date. 


\section{ASSESSMENT AND RECOMMENDATIONS}

12. General assessment of vigor, trends, and status--Given the high level of cowbird parasitism throughout the vireo's range, it is not clear how existing populations are being maintained.

A. Fort Sill--Existing habitat is probably stable. Most exists on boulder-strewn hillsides with shallow soils that likely will not change much with time as long as there are no major disturbances. The vireo population declined from 17 or 18 adults in 1988 to 6 in 1989, and 8 in 1990. This appears to be a natural fluctuation in this marginal part of the existing vireo range and is unrelated to military activity. Production during 1988 through 1990 averaged 1.0 to 1.4 young per mated pair.

B. Fort Hood--The population seems stable at about 280 adult birds despite poor reproductive success. The population appears to be supported by immigration from areas off-post. Habitat availability has been and probably will continue to be enhanced by military activity. Most existing colony sites can coexist with current land uses although there is some risk of negative effects on certain sites. Production ranged from 0.3 to 1.8 young per mated pair during 1987 through 1989.

C. Camp Bullis--This population also seems stable at about 35 or 36 adult vireos. Present mission and land use management activities probably are not likely to jeopardize the vireo. Reproductive success has not been documented. Habitat is likely to be maintained by natural and military related fires.

\section{Recommendations for listing or status change}

\section{A. Recommendations to U.S. Fish and Wildlife Service}

1. Recommended U.S. federal status--The Black-capped Vireo should be maintained as an endangered species throughout its present range. A substantial contraction in its historic range has been well documented and reproductive success continues to be limited severely by cowbird parasitism.

2. Recommended priority for federal action--Review current status for Texas after a more thorough assessment of the current population size. Recent evidence indicates the population may be far larger than originally anticipated.

B. Recommendations to other U.S. federal agencies--Maintain current status.

\section{Other status recommendations}

\section{Counties and local areas--None.}

2. States--Texas: consider possible down-grading to threatened after a more thorough assessment of current population size. Oklahoma: maintain endangered status.

3. Other nations--Mexico: endangered species status.

4. International Trade Convention--None. 
14. Recommended critical habitat--None. The ephemeral nature of the vireo's habitat makes designation of critical habitat inappropriate.

\section{Conservation/recovery recommendations}

\section{A. General conservation recommendations}

1. Habitat--On Fort Hood, habitat should be developed in areas least likely to conflict with mission activities while continuing to protect existing habitat. Habitat development, planned and accidental, should be avoided in areas highly used/desirable for training. Although prescribed burning is a preferred method for maintaining existing habitat and developing new habitat, other means of habitat development should be investigated.

2. Cowbird parasitism--Presently, the most serious threat to the Black-capped Vireo on Army lands is cowbird nest parasitism. Especially at Fort Hood, the Army should evaluate the relationship between cattle grazing and cowbird abundance and develop more effective methods of controlling cowbirds. Fort Hood also should consider modifying or eliminating the existing cattle grazing program.

3. Other recommendations--The Army should work with other state and federal agencies in developing of a regional approach to management and eventual recovery of the species.

B. Monitoring Activities--Annual monitoring of distribution and abundance of the vireo on each installation should continue. Continue to monitor reproductive success of a representative sample of birds on each installation. Land use and management activities should be adjusted as necessary according to the results of inventory and monitoring. Habitat should be monitored using Land Condition Trend Analysis methodologies (Tazik et al. 1991).

16. Interested parties--Arlington District Office, U.S. Fish and Wildlife Service; Texas and Oklahoma Natural Heritage programs; Nature Conservancies of Texas and Oklahoma; National Wildlife Federation; Dr. Joseph Grzybowski, Norman, OK; City of Austin.

\section{INFORMATION SOURCES}

\section{Sources of Information}

\section{A. Publications}

\section{References cited in report}

American Ornithologisit's Union. 1983. Check-list of North American Birds. 6th edition. Allen Press, Lawrence Kansas.

Bailey, R.G. 1980. Descriptions of ecoregions of the United States. USDA Forest Service Miscellaneous Publication Number 1391.

Barlow, J.C. 1981. Songs of the Vireonidae. Disc. ARA records, J.W. Hardy, Gainesville, Florida.

Bruns, M.E. 1988. Natural resources management plan for the Camp Bullis Training Site, Fort Sam Houston, Texas. (Draft) 
Bunker, C.D. 1910. Habits of the Black-capped Vireo (Vireo atricapillus). Condor 12: 70-73.

Deignan, H.G. 1961. Type specimens of birds in the United States National Museum. Bulletin of the U.S. National Museum 221:1-718.

Graber, J.W. 1957. A bioecological study of the Black-capped Vireo (Vireo atricapillus). Ph.D. dissertation, University of Oklahoma, Norman, Oklahoma.

Graber, J.W. 1961. Distribution, habitat requirements, and life history of the Black-capped Vireo (Vireo atricapilla). Ecological Monographs 31:313-336.

Grzybowski, J.A. 1985a. Final Report: Population and nesting ecology of the Blackcapped Vireo (Vireo atricapillus). Part I: Population status of the Black-capped Vireo in Oklahoma1985. Report submitted to U.S. Fish and Wildlife Service, Office of Endangered Species, Albuquerque, New Mexico,

Grzybowski, J.A. 1988a. Performance Report: Population and nesting ecology of the Black-capped Vireo (Vireo atricapillus) in Oklahoma. Report submitted to Oklahoma Department of Wildlife Conservation, Oklahoma City, Oklahoma.

Grzybowski, J.A. 1989a. Interim Report: Black-capped Vireo investigations: Population and nesting ecology. Report submitted to U.S. Fish and Wildlife Service, Office of Endangered Species, Albuquerque, New Mexico.

Grzybowski, J.A. 1989b. Ecology and management of the Black-capped Vireo (Vireo atricapillus) in the Wichita Mountains, Oklahoma. Report submitted to Wichita Mountains National Wildlife Refuge, U.S. Fish and Wildlife Service, Indiahoma, Oklahoma.

Grzybowski, J.A. 1990. Final Report: Population and nesting ecology of the Black-capped Vireo in Texas -- 1988-1989.

Grzybowski, J.A., R.B. Clapp, and J.T. Marshall, Jr. 1986. History and current population status of the Black-capped Vireo in Oklahoma. American Birds 40:1151-1161.

Grzybowski, J.A. and D.J. Tazik. 1990. Status Report: The Black-capped Vireo at Fort Sill, Oklahoma -- 1988-1990. Report submitted to Natural Resource Management Branch, Environmental Division, Fort Sill, OK.

Johnson, F.L., R.A. Thompson, R. Rudman, J.R. Estes, G.D. Schnell, and K.D. Harris. 1990. Floral inventory of Fort Sill, Oklahoma. Report submitted to Environmental Division, U.S. Army Construction Engineering Research Laboratory, Champaign, IL.

Marshall, J.T., R.B. Clapp and J.A. Grzybowski. 1985. Status Report: Vireo atricapillus (Woodhouse), Black-capped Vireo. Prepared for the Office of Endangered Species. U.S. Fish and Wildlife Service, Albuquerque, New Mexico.

Nakata Planning Group, Inc. 1987. Master plan report: Fort Hood, Texas. U.S. Army Corps of Engineers, Fort Worth, Texas.

NOAA. 1982. Monthly normals of temperature, precipitation, and heating and cooling degree days 1951-1980. Climate of the United States No. 81 (by State). 
Pulich, W. 1976. An evaluation of the Camp Bullis Training Site, Texas, A potential National Landmark Site. (photocopy)

Robbins, C.S., D. Bystrak, and P.H. Geissler. 1986. The breeding bird survey: its first fifteen years, 1965-1979. U.S. Fish and Wildlife Service, Resource Publication.157.

Rust, S.P. and D.J. Tazik. 1990. Endangered Bird Survey on Camp Bullis Training Reservation, Fort Sam Houston, Texas. Report submitted to Environmental Division, Fort Sam Houston, Texas.

Severinghaus, W.D., R.S. Baran, and R.E. Riggins. 1980. Ecological Baseline--Fort Hood, Texas. USACERL Technical Report N-95.

Shaw, D.M., D.J. Tazik, J.M. Coffey, and S.F. Atkinson. 1989. Status report: The Black-capped Vireo on Camp Bullis, Fort Sam Houston, Texas. Report submitted to Fort Worth District Corps of Engineers. Center for Remote Sensing and Landuse Analyses, University of North Texas, Denton, Texas.

Tazik, D.J, and J.D. Cornelius. 1990. The Black-capped Vireo on the lands of Fort Hood, Texas. Part III: Population and nesting ecology. USACERL Draft Technical Report, October 1990.

Tazik, D.J., S. D. Warren, V.E. Diersing, R.B. Shaw, R.J. Brozka, C.F. Bagley, and W.W. Whitworth. 1991. U.S. Army Land Condition-Trend Analysis (LCTA) Field Methods. USACERL Draft Technical Report, April 1991.

Tazik, D.J, J.D. Cornelius, C.A. Abrahamson, and V.E. Harmon. 1990. The Black-capped Vireo on the lands of Fort Hood, Texas. Part I: distribution and abundance. USACERL Draft Technical Report, October 1990.

Tazik, D.J, J.D. Cornelius, and D.M.Herbert. 1990. Biological assessment of the effects of military associated activities on endangered species at Fort Hood, Texas. Draft October 1990.

Tordoff, H.B. 1956. Checklist of the birds of Kansas. University of Kansas Museum of Natural History Publication 8:307-359.

Visher, S.S. 1954. Climatic atlas of the United States. Harvard University Press, Cambridge, MS.

Woodhouse, Samual W. 952. Descriptions of new species of the genus Vireo, Vieill., and Zonotrichia, Swains. Proceedings of the Academy of Natural Sciences of Philadelphia 6:60. 


\section{Other pertinent publications}

\section{a. Technical}

Bryan, K.B. and D.K. Stuart. 1990. Black-capped Vireo Project, 1990: Results and Summary. Performance Report, Project E-1-2, Job No. 3.2--Black-capped Vireo Management on Department Lands, Texas Parks and Wildlife, Austin, Texas.

Grzybowski, J.A. 1985b. Final Report: Population and nesting ecology of the Blackcapped Vireo (Vireo atricapillus). Part II: Nesting ecology of the Black-capped Vireo. Report submitted to U.S. Fish and Wildlife Service, Office of Endangered Species, Albuquerque, New Mexico.

Grzybowski, J.A. 1986. Interim Report: Population and nesting ecology of the Blackcapped Vireo (Vireo atricapillus). Report submitted to U.S. Fish and Wildlife Service, Office of Endangered Species, Albuquerque, New Mexico.

Grzybowski, J.A. 1987. Performance Report: Population and nesting ecology of the Black-capped Vireo (Vireo atricapillus) in Oklahoma. Report submitted to Oklahoma Department of Wildlife Conservation, Oklahoma City, Oklahoma.

Grzybowski, J.A. 1988b. Report: Black-capped Vireo investigations -- 1986-87. Part I: Population and nesting ecology. Report submitted to U.S. Fish and Wildlife Service, Office of Endangered Species, Albuquerque, New Mexico.

Grzybowski, J.A., G. D. Schnell, and D.J. Tazik. 1990. Regional analysis of Blackcapped Vireo Habitats. Southwestern Association of Naturalists, Denton, Texas, April 1990.

Pease, C.M. and L.G. Gingerich. 1989. The habitat requirements of the Black-capped Vireo and Golden-cheeked Warbler populations near Austin, Texas. Department of Zoology University of Texas, Austin, Texas.

b. Popular--Unknown.

\section{B. Museum collections consulted--None.}

C. Fieldwork--U.S. Army Land Condition-Trend Analysis Group, Construction Engineering Research Laboratory, Champaign, IL; and Fish and Wildlife Section, Fort Hood, Texas.

D. Knowledgeable individuals--Dr. David J. Tazik (U.S. Army CERL, P.O. Box 9005, Champaign, IL 61826-9005); Mr. John D. Cornelius (Fish and Wildlife Branch, Fort Hood, Texas); Dr. Joseph A. Grzybowski (Norman, OK); Ms. Susan Rust (Stewardship Services, San Antonio, TX); Dr. Thomas Martin (Fish and Wildlife Cooperative Research Unit, University of Arkansas, Fayetteville, AR).

18. Summary of information on file--Inventory and monitoring data from Fort Hood (1987-1989), and Camp Bullis (1989-1990) (USACERL); photographs (USACERL). Fort Sill data--Dr. Joseph Grzybowski, Norman, OK; Camp Bullis data--Ms. Susan Rust, San Antonio, TX. 


\section{AUTHORSHIP}

19. Initial authorship--Dr. David J. Tazik, Environmental Division, U.S. Army Construction Engineering Research Laboratory, P.O. Box 9005, Champaign, IL 61826-9005, 217/398-5443.

20. Maintenance of status report--Unknown.

V. NEW INFORMATION

21. Record of revisions--None. 